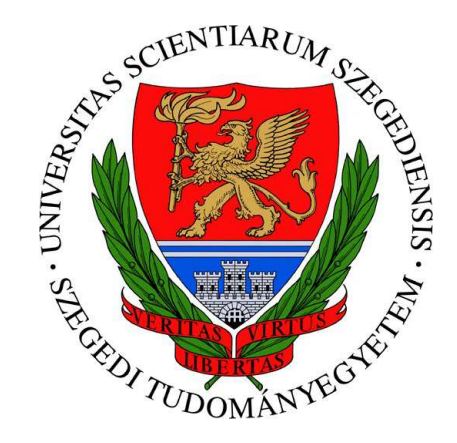

\title{
Kalciumiontartalmú csapadékok mintázatképződése
}

\author{
Doktori (Ph.D.) értekezés
}

\section{Bohner Bíborka}

Témavezető: Dr. Horváth Dezső, egyetemi tanár

\section{Kémia Doktori Iskola}

Szegedi Tudományegyetem, Természettudományi és Informatikai Kar Fizikai Kémiai és Anyagtudományi Tanszék 


\section{Tartalomjegyzék}

1. Bevezetés 5

2. Irodalmi áttekintés $\quad \mathbf{1 0}$

2.1. Időben periodikus struktúrák . . . . . . . . . . . . . . 10

2.2. Térben periodikus struktúrák f . . . . . . . . . . . . . 12

2.2.1. Frontreakciók, hullámok és Turing-mintázatok . . . . . . . . . . 12

2.2.2. Csapadékmintázatok kialakulása oldatfázisból . . . . . . . . . . 15

2.2.3. Csapadékmintázatok előállítása gélben . . . . . . . . . . . . . 16

2.2.4. Áramlásvezérelt csapadékmintázatok . . . . . . . . . . . . . . . 19

2.2.5. A csapadékmintázatok összehasonlítása . . . . . . . . . . . . 23

2.3. A kalcium-oxalát és a kalcium-karbonát . . . . . . . . . . . . . . . . . . . 24

$\begin{array}{ll}\text { 3. Célkitúzés } & 27\end{array}$

4. Kísérleti rész 28

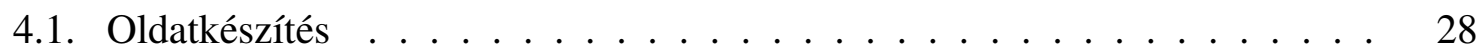

4.1.1. Az áramlásvezérelt kísérletekhez . . . . . . . . . . . . . . . 28

4.1.2. Az enzimreakcióhoz . . . . . . . . . . . . . 28

4.2. Kísérleti elrendezés . . . . . . . . . . . . . . . . . . . . . . . . 29

4.2.1. A csapadékmintázatok tanulmányozása . . . . . . . . . . . . . 29

4.2.2. Az enzimreakció tanulmányozása . . . . . . . . . . . . . 30

4.3. Alkalmazott múszerek és eszközök . . . . . . . . . . . . . . . . . . . 31

4.3.1. Termogravimetria . . . . . . . . . . . . . . 31

4.3.2. Infravörös spektroszkópia . . . . . . . . . . . . . . 31

4.3.3. Raman-spektroszkópia . . . . . . . . . . . . . . . . 31

4.3.4. Spektrofotometria ................. 32

4.3.5. Mikroszkópiás vizsgálatok . . . . . . . . . . . . . . 32

4.3.6. A súrúség és a viszkozitás meghatározása . . . . . . . . . . . . . 33

4.4. Kiértékelési módszerek . . . . . . . . . . . . . . . . . . . 33

4.4.1. Az áramlásvezérelt csapadékmintázatok esetén alkalmazott módszerek 33

4.4.2. Az enzimreakciók során alkalmazott módszerek . . . . . . . . . . . 37

4.5. Ábrázolás . . . . . . . . . . . . . . . . . . . 37 
4.6. Egyensúlyi számítások . . . . . . . . . . . . . . . 38

5. Kalcium-oxalát csapadékmintázat 39

5.1. A koncentrációeloszlás számítása . . . . . . . . . . . . . . . . . . . 39

5.2. A reaktánsok koncentrációjának változtatása . . . . . . . . . . . . . 41

5.2.1. A csapadékkorong területének változása az időben . . . . . . . . . 44

5.3. A nátrium-oxalát-oldat kémhatásának változtatása . . . . . . . . . . . . . 46

5.4. A közegmozgás mintázatképződésre gyakorolt hatása . . . . . . . . . . . . 47

5.4.1. A kalcium-klorid-oldat térfogat-áramlási sebességének változtatása 47

5.4.2. A viszkozitás és a sûrűség hatása a mintázatképződésre . . . . . . . 48

5.5. Termogravimetriás analízis . . . . . . . . . . . . . . . 51

5.6. Infravörös spektroszkópiás vizsgálat . . . . . . . . . . . . . . . 54

5.7. Raman-spektroszkópiás vizsgálat . . . . . . . . . . . . . . . 55

5.8. Pásztázó elektronmikroszkópiás felvételek . . . . . . . . . . . . . . . 59

6. Kalcium-karbonát csapadékmintázat $\quad 62$

6.1. A koncentrációeloszlás számítása . . . . . . . . . . . . . . . 62

6.2. A mintázat jellemzése . . . . . . . . . . . . . . . . . . . . . . . 64

6.3. A külső csapadékkör méretének változása a reakció idôtartama alatt . . . . 67

6.4. Termogravimetriás analízis . . . . . . . . . . . . . . . . . 68

6.5. A mikroszerkezet és a méreteloszlás vizsgálata . . . . . . . . . . . . . 69

6.6. Raman-mikroszkópiás vizsgálatok . . . . . . . . . . . . . . . . 74

7. Kalcium-oxalát-kalcium-karbonát mintázatok 76

7.1. A koncentrációeloszlás számítása . . . . . . . . . . . . . . . 76

7.2. Az oldatok koncentrációinak változtatása . . . . . . . . . . . . . . . . 78

7.3. Pásztázó elektronmikroszkópiás és Raman-mikroszkópiás analízis . . . . . 81

8. Kalcium-karbonát csapadék előállítása a karbamid-ureáz enzimreakcióban 84

8.1. A karbamid és az ureáz enzim között lejátszódó órareakció . . . . . . . . . 84

8.1.1. A karbamid-ureáz enzim órareakció nyílt és zárt edényben . . . . 85

8.1.2. A karbamid-ureáz enzim órareakció kalciumionokkal . . . . . . . . 86

8.2. Lépcsôzetes kalcittermelés és az oszcilláló karbamid-ureáz enzimreakció 92

8.2.1. A kialakult csapadék pásztázó elektronmikroszkópiás vizsgálata . . 97

8.2.2. A kialakult csapadék Raman-mikroszkópiás vizsgálata . . . . . . . 98

8.2.3. Az oszcilláló kémiai reakció kontrollkísérlete . . . . . . . . . . . . 98

8.3. Az órareakció és az oszcilláció együttes megjelenése . . . . . . . . . . . . 100

$\begin{array}{lll}\text { 9. Összefoglalás és diszkusszió } & 101\end{array}$

$\begin{array}{lll}10 & \text { Summary and Discussion } & 106\end{array}$ 
I. A mintázatképződés illusztrálására szolgáló kísérletek leírása 120

I.1. Spirálok képződése a Belouszov-Zsabotyinszkij-reakcióban ..... . 120

I.2. Az alumínium-hidroxid mozgó csapadékmintázat . . . . . . . . . . . . . . 120

I.3. Szilikátnövények . . . . . . . . . . . . . . . . . . . . . 121

I.4. Réz-oxalát szálas csapadékmintázat . . . . . . . . . . . . . . . 121

II. Termogravimetriás számítások $\quad 122$

III. Számítások a Wolfram Mathematica Programmal 123

III.1. Egyensúlyi számítások bemeneti adatai . . . . . . . . . . . . . . . . 123

III.2. Háromparaméteres egyenlet illesztése a csapadékkör külső sugarának növekedésére . . . . . . . . . . . . . . . . . . . . . . . 124

III.3. A pH számítása kalciumionok és ammónium-karbonát mellett . . . . . . 125

IV. A karbamid-ureáz-kalciumion oszcilláló kémiai reakció modellezésének elôzetes eredménye 


\section{1. fejezet}

\section{Bevezetés}

Sokan szembesültek azzal tanulmányaik során, hogy a természetben lejátszódó legtöbb jelenség nem írható le lineáris változásokkal. Ezek miatt nem is meglepő, hogy a nemlineáris dinamika tudományterülete interdiszciplináris sajátságokkal bír: a feltárt elméleteket sikeresen alkalmazták sok egymástól alapjaiban eltérố folyamat jellemzésében. A bevezetésben ezért olyan szemléletes példákon keresztül ismertetem a dolgozat szempontjából releváns jelenségeket, melyek hasonló elméleti alapokon nyugszanak, de a legkülönbözőbb tudományok és a múvészetek területérôl származnak.

Ha szabályos időközönként ugyanaz az esemény megismétlődik, és ezáltal egy késôbbi állapot jósolhatóvá válik, akkor idôben periodikus jelenségrôl, azaz oszcillációról beszélünk. Emlékezzünk csak vissza korai fizika tanulmányainkra, amikor kisiskolásként elbűvölt az ingák periodikus, oszcilláló mozgása! Lapozzunk fel egy-egy zenei akusztika jegyzetet vagy könyvet, mely a levegő részecskéinek mozgását tanulmányozza. Amint beleolvasunk, az 1.1. ábrához hasonló görbéket figyelhetünk meg. Itt egy hegedûn, trombitán, fuvolán, és oboán megszólaltatott $440 \mathrm{~Hz}$ frekvenciájú A' hang amplitúdója látható az idố függvényében ábrázolva. Ezen megfigyelhetjük, hogy bárhol is választjuk ki $T$ periódusidô kezdőpontját, minden $T$ időegység elteltével ugyanazon értéket fogjuk leolvasni a diagramról. Sokszor elegendő csupán a lineáris összefüggéseket figyelembe venni bizonyos problémák megoldásához, mint például ahhoz, hogy fúvós hangszereken a hanglyukak elhelyezkedését és a rezgố részek rezonanciáját meghatározzuk. Ha azonban elég kitartóak vagyunk és tovább kutakodunk az irodalomban, akkor nem kell csalódnunk. Akadnak olyan területek, mint például a hangszerek megszólaltatásának mechanizmusa, melyek a legkevésbé sem jellemezhetôek a nemlineáris dinamika eszköztára nélkül. Fletcher bemutatta, hogy a kisugárzott hangerôt, a felhangok intenzitását és a hangszínnek a különböző paraméterektől - többek között a játékos fúvástechnikájától vagy a befúvás szögétől való függését - megértsük, a hangszerek nemlineáris viselkedését kell tanulmányoznunk például a klarinét esetében a térfogatáram-nyomás függését [1]. Ha a közönség soraiban ülő nézőknek tetszett a hangszeres játék vagy az előadás, akkor elégedettségüket hangos tapsolással fejezik ki. A tapsolás dinamikája szintén leírható a nemlineáris dinamika eszköztárával felfegyverkezve. Bara- 
bási és munkatársai Romániában valamint Magyarországon színházi- és operaelőadásokat tanulmányoztak. Megfigyelték, azt követôen pedig modellszámításokkal is alátámasztották, hogy random tapsolásból - periódus-kettőződés után - lassabb, periodikus tapsolás (vastaps) alakul ki [2].

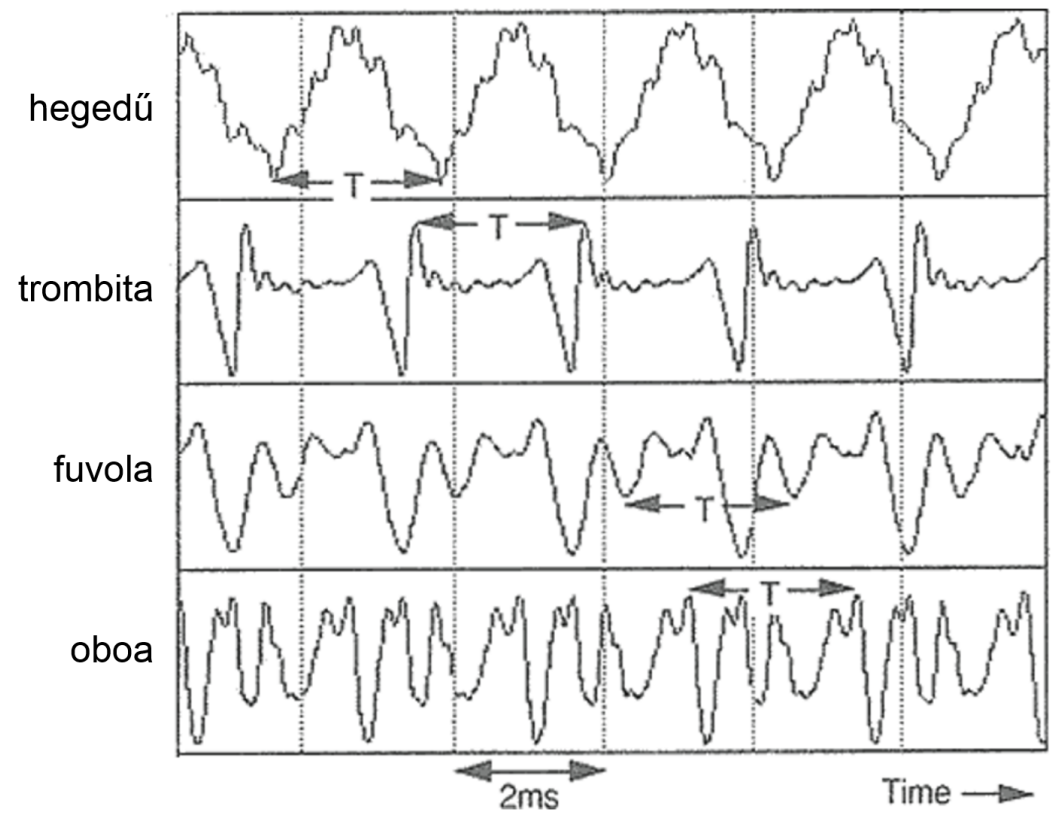

1.1. ábra. Periodikus jelenségek (T periódusidővel): a 440 Hz frekvenciájú A' hang megszólaltatása hegedún, trombitán, fuvolán és oboán [3].

Mosolyt csal az arcunkra, amikor ázott kutyánk - testének periodikus oszcillációjával pillanatok alatt megszárítja bundáját [4]. Ha ezt a mozgást a nemlineáris dinamika szemszögéből vizsgáljuk, akkor megadhatjuk például az oszcilláció periódusidejét, ami meglepóen kis érték: 0,2 másodperc, azaz rendkívül gyors mozgás egy felnőtt labrador esetén. További érdekes összefüggések tárulnak fel eloottünk, ha figyelembe vesszük az emlősök méretét és szôrük hosszát is.

Vegyük most szemügyre a gazdasági változásokat, ahogyan azt Nyikolaj Dmitrijevics Kondratyjev szovjet-orosz közgazdász is tette [5]. A vagyongyarapodást az idő függvényében ábrázolva Kr. u. 1800-tól öt csúcsot különböztethetünk meg, amelyeket a I. gôzgép, II. a vasútépítés, III. az elektromosság és a nehézipar, IV. az olajipar és az autógyártás, valamint V. az informatika és a lézertechnika elterjedése idézett elô. Ezeket a hosszú, kb. 50 éves periódusidejú ciklusokat Kondratyjev-ciklusoknak (más néven K-hullámoknak) nevezzük, amelyek új technológiák bevezetése, elterjedése és kifutása során alakultak ki. A periodicitás előnye, hogy a következő ciklus és periódusideje jósolható, amelyben - az előrejelzések szerint - a nanotechnológiáé és a biotechnológiáé lesz a fôszerep. 
Múszaki tudományok területén ez az időbeli ismétlődés például oszcilláló termékképződésként, vagy katalizátor felületén végbemenő oszcillációként jelentkezik [6].

Ha egy hideg téli estén karácsonyi hangulatban pislákoló gyertyák lángját kémleljük, nekünk is megakadhat a tekintetünk a következő nemlineáris jelenségen [7]: amikor háromszög alakzatban három égő gyertyát egymástól egyenlő $(3-6 \mathrm{~cm})$ távolságban elhelyezünk, akkor külső zavarás nélkül - ilyen lehet például a légfuvallat - lángjuk szinkronizálódik, azaz pislákolásuk egymástól függeni fog. Ha a fényerốt az idő függvényében ábrázoljuk, akkor a lángok lobogása közben oszcillációt detektálhatunk. Az égés folyamán négyféle szakaszt különíthetünk el: elsôként mindhárom láng azonos fázisban van, azaz ugyanolyan hullámformával és periódusidôvel oszcillálnak. Ez az állapot azonban instabil. A második módban az oszcilláció hullámformája azonos, de időben eltolódik az egyik gyertya lángjának lobogása. A harmadikban mindhárom gyertya lángjának pislákolása egy konstans időértékkel későbbi fázisban található. Az utolsó esetben pedig a gyertyák stabilan égnek, pislákolás és oszcilláció nélkül. Kettő, négy, öt, nyolc és tíz láng együttes vizsgálatakor további érdekes eredményekre lehetünk figyelmesek, például ha egy gyertyát központi helyre teszünk, lángját együttesen erôsítik a körülötte lévő lángok. A lángok szinkronizációját azzal magyarázták, hogy amikor a gyertyák által felmelegített levegô kisebb sưrúségúvé válik, az felfelé halad, ezáltal légörvényeket generál, melyek az összes gyertya esetén kölcsönösen hatnak egymásra [8].

Az oszcilláció kémiai rendszerekben akkor következik be, ha a köztitermékek koncentrációja periodikusan váltakozik a reakció időtartama alatt. Ha ezeknek a komponenseknek nincs utánpótlása, akkor az oszcilláció előbb-utóbb csillapodik, majd véget ér. Már a 17. század végén felfigyelt a jelenségre Robert Boyle, aki foszfor oxidációja közben lumineszcens felvillanásokat tapasztalt [9]. Az elsô oldatfázisú oszcilláló kémiai reakciót azonban csak 1921-ben publikálta Bray, de a reakció mechanizmusának felderítésében Liebhafsky munkásságát tekintjük úttörônek. A Bray-Liebhafsky-reakció során a hidrogénperoxid jodátion hatására oxigénre és vízre bomlik $[10,11]$. A több napos periódusidejú oszcillációt a jódmolekulák koncentrációjában figyelhetjük meg. Az 1950-es években már Belouszov is észlelte az oszcilláció jelenségét, miközben a sejtbeli oxidáció leegyszerúsített, kémiai modelljét próbálta megalkotni szervetlen oxidálószer jelenlétében. Az általa vizsgált cérium(III)/cérium(IV)ion-bromátion-citromsav reakcióban az oldat színtelen és sárga szín közötti periodikus váltakozását tapasztalta. Felfedezését azonban nem tudta a tudományos közösséggel megismertetni, mert a folyóiratok szerkesztői nem fogadták el a publikációt, arra hivatkozva, hogy a reakció a leírt módon nem mehet végbe, hiszen nem tesz eleget a termodinamika II. főtételének. Eredményeit ezért csak 1959-ben, egy moszkvai orvoskonferenciáról szóló beszámolóban közölhette. Zsabotyinszkij 1961-ben kísérleteivel nem csak igazolta Belouszov eredményeit, hanem a reaktánsok módosításával a bromátionmalonsav-ferroin reakcióban a piros-kék szín periodikus változását hozta létre [12]. Ma már Belouszov-Zsabotyinszkij-reakciónak (BZ) tekintünk minden olyan kémiai reakciót, amely 
során valamilyen szerves anyagot savas közegben átmenetifémion katalizátor mellett bromátionnal oxidálunk.

Ezzel szemben azokat a szabálytalan vagy véletlenszerü viselkedéseket, amelyek időben nem ismétlik önmagukat, és így nem is jelezhetőek előre, kaotikusnak tekintjük [13]. Bifurkációt és determinisztikus káoszt mutat a harangok, a gongok, és a réztányérok nemlineáris rezgése fortissimo ütéseknél, de a hangszalagok rezgése is, például amikor az emberi hang váratlanul magasabb lesz - többnyire izgalom vagy feszültség hatására. Képzeljük el, hogy milyen nagy eséllyel hallathat a hangszer rikácsoló, sípoló hangot, ha egy meg nem nedvesített náddal játszik az oboista! Hiszen ha a zenész a hangindításkor túl erôsen fújja meg a hangszert, akkor visszavert hullámok hiányában jóval magasabb frekvenciájú nádhang is képződhet. A nemlineáris nádrezgés ugyanis nagyon érzékeny a perturbációra. Vagy ha a koncert közben folyamatosan melegszik a levegő - bizony változik a hangszerek csövének az átmérője, így a megszólaltatott hang már nem azon a frekvencián szól, mint az előadás elején. Ebből is látszik, hogy zenészként nincsen könnyú dolgunk! Alkalmas kezdeti feltételeket kell választanunk hangszerünk megszólaltatásához, és folyamatos paraméterkorrekciót kell végrehajtanunk annak érdekében, hogy elkerüljük a kaotikus rendszermúködést vagy esetleg szabályozzuk azt. Hogy hogyan? Sok éves vagy évtizedes gyakorlás, tapasztalat és ,jó” hallás segítségével [14].

Jogosan gondolhatnánk, hogy kémiai rendszerekben a káosz nem szabályozható, hiszen piciny zavarásokkal csak azt érnénk el, hogy rendszerünk egy újabb kaotikus, megjósolhatatlan állapotba jusson... A fent említett BZ-reakcóban létrejöhet az oszcilláció mellett a kiindulási feltételekre extrém érzékeny determinisztikus káosz is, melyet Showalter és munkatársai azonban „megszelídítettek” [15,16], azaz, kísérletileg egy (vagy több) paramétert folytonosan perturbáltak, amivel előre jelezhető, azaz periodikus viselkedést tudtak előidézni.

Térbeli periodicitásra figyelhetünk fel, ha szervetlen vegyületek csapadékképződési reakciója során kialakuló kôzetek színpompás mintázatában vagy akár az állatok jellegzetes pöttyös, foltos, csíkos kültakarójában gyönyörködünk. Ekkor különféle színek periodikus megjelenése vagy szimmetriája az, ami magával ragadja a szemléloót, de a természettudóst is.

Kondot is elbúvölte a bársony és színváltó császárhalak csíkokkal borított mintázata, ezért elhatározta, hogy megvizsgálja ezeknek a színes sávoknak a kialakulását [17]. Munkatársával arra a következtetésre jutottak, hogy a mintázatot kialakító jelenség a reakciódiffúzió hullám, majd modellszámításaikkal meg is jósolták az állatok kültakaróján bekövetező változásokat.

Kémiai rendszerekben ilyen mintázatok megjelenését kémiai reakciók és transzportfolyamatok együttes hatása biztosítja. Mindezek megértéséhez ismernünk kell a jelenséget befolyásoló folyamatokat. Transzportfolyamatok akkor jelentkeznek, ha anyag, energia, impulzus vagy töltés elmozdulása következik be [18]. Az anyagi részecskék leggyakrabban háromféle úton: diffúzió, konvekció vagy migráció segítségével képesek helyváltoztatásra. Diffúzió esetében a részecskék elmozdulása koncentrációgradiens hatására, annak ellenében 
történik. A töltéssel rendelkező részecskék elektromos potenciálkülönbség okozta helyváltoztatását migrációnak, míg a makroszkopikus közegáramlás útján létrejövőt konvekciónak nevezzük. A természetben járva lépten-nyomon azonosítani tudjuk ezeket a folyamatokat, hiszen szerepet játszanak a felhôk és az áramlatok kialakulásában, valamint a vízi élővilág számára elengedhetetlen oxigénmolekula transzportját is biztosítják a légkörből a vizekbe. Továbbá sejtjeink múködésében, a sejthártyán történô energiabefektetés nélküli passzív anyagtranszportban is szerephez jutnak, amely vagy koncentrációgradiens hatására, vagy töltések kiegyenlítődése végett következik be. Érdekes kísérlet a transzportfolyamatok hatásával kapcsolatban, hogy a nagy koncentrációgradiens következtében a Physarum polycephalum nyálkagomba megtalálja a legrövidebb utat egy labirintus útvesztôiben [19], de képes erre egy mikrofluidikai rendszerben lévő folyadék [20] és a plazmakisülés is [21]. A transzportjelenségek pontos ismerete az ipari eljárások során sem hanyagolható el, fontos szerepük van például a hőátadási folyamatokban és a fluidumok áramlásában. Sajnos ezen transzportfolyamatok a környezeti katasztrófák esetében is múködésbe lépnek, és segítségükkel a szennyezések nagy távolságokra eljuthatnak. Gondoljunk csak a mezőgazdasági területekről a folyóvizekbe kerülő nagy mennyiségú foszfátion-, és nitrátion-tartalmú mútrágyák eutrofizációs hatásaira. Említhetnénk még a baleset következtében radioaktív anyag emissziójával járó 1986. április 26-án hajnalban bekövetkezett csernobili katasztrófát [22], és a 2010. október 4-ei ajkai vörösiszap-katasztrófát is, amely nem csak iszap, de később por formájában egyaránt igen káros hatással volt az élő és élettelen környezetre [23]. A transzportfolyamatok tehát befolyásolják mindennapi életünket, ezért fontos, hogy minél jobban megismerjük és kísérletileg is tanulmányozzuk ôket.

A körülöttünk lévő világban mindenütt jelen vannak, érzékszerveinkkel érzékelhetőek, hallhatóak és láthatóak ezek a nemlineáris jelenségek. Közös jellemzôjük az egyensúlytól távoli állapot és a pozitív visszacsatolás. A reakciók kinetikája - időbeli lefolyása és mechanizmusa -, a heterogén rendszerben képződött mintázatok esetében pedig a csapadékképződés folyamata bír autokatalitikus tulajdonságokkal. Doktori munkám során mind térbeli, mind időbeli periodicitást vizsgáltam kalcium-oxalát és kalcium-karbonát csapadékok képződése közben. 


\section{2. fejezet}

\section{Irodalmi áttekintés}

\subsection{Idôben periodikus struktúrák}

Ha egy folyamatban a köztitermékek koncentrációjának változása időben periodikus, akkor oszcilláló kémiai reakcióról beszélünk. A kémiai oszcilláció kialakulásának feltételei, hogy a reakció távol legyen a termodinamikai egyensúlyi állapottól, legyenek benne pozitív visszacsatolást tartalmazó (autokatalitikus vagy öninhibíciós) lépések, valamint legalább egy negatív visszacsatolás [24]. Zárt rendszerben kizárólag tranziens, csillapodó oszcilláció jöhet létre, míg a komponensek folyamatos anyagáramlását lehetôvé tevố nyílt rendszerben állandó amplitúdójú oszcilláció is megvalósulhat. Ezen rendszerek talán legismertebb példája a BZ-reakció, de számos újabb példát is találunk az irodalomban, ilyenek a bromátion, jodátion, stb. alapú oszcillátorok [25]. Grzybowski és munkatársai egy pH-oszcillátor és ezüst, illetve arany nanorészecskék segítségével hoztak létre oszcilláló reakciót. A folyamat során a töltéssel rendelkezô nanorészecskék a kémhatás függvényében periodikusan aggregálódnak és szétválnak, ami kémiai oszcillációt eredményez [26]. Az elmúlt évek eredményei közé tartozik az a kísérletsorozat is, amelyben a bromátion-szulfition-ferrocianidion reakciót a kalciumion etilén-diamin-tetraacetát pH-érzékeny komplexképződésével csatolva, pH-, és termékoszcilláció, ezen túl térbeli kalciumion mintázat is létrehozható [27].

Számos biokémiai oszcillátor ismert, melyben rendkívül bonyolult molekulák meglepôen egyszerú mechanizmus szerint viselkednek. Ezek szinte kivétel nélkül enzimkatalizálta folyamatok, melyekben pozitív és negatív visszacsatolások idézik elő az oszcillációt [28]. Az enzimek érzékenyek a környezetükre, így annak kémhatására is. Aktivitásuk jelentősen függ a pH-tól, ami gyakran harang alakú görbét ír le. A karbamid-ureáz enzimreakció is ezek közé tartozik, melynek maximális aktivitása semleges kémhatású ( $\mathrm{pH}=7,0)$ környezetben található. Kinetikáját jól jellemzi a Michaelis-Menten-egyenlet. Számításokkal meghatároztak olyan paraméterértékeket, melyek alkalmazásakor oszcilláció alakul ki az ureáz enzimmel töltött membrán vagy sejt szubsztrátoldatba helyezésekor, vagy nyílt reaktorban [29]. Ugyanebben a rendszerben órareakciót sikerült bemutatnia Taylornak és munkatársainak. 
Ez a báziskatalizált, hidroxidionra autokatalitikus rendszer rendkívül érzékeny a kiindulási pH-ra. Ha a kiindulási elegyhez savat adnak, akkor kezdetben kis (savas) a pH-t detektálnak. Ahogy az enzimmúködés eredményeként ammónia képződik, úgy nő a pH. Eközben a sebesség egyre gyorsul, és az órareakcióknál megfigyelt tipikus szigmoidális görbék detektálhatóak. Ugyanebben a rendszerben folyamatosan kevert tankreaktorban - karbamid, kénsav, és az ureáz enzim beáramoltatásakor - bistabilitást és hiszterézist figyeltek meg a szerzők. Ezen túl, pH-oszcillációt kísérletileg is bemutattak, amely a 2.1. ábrán látható [30].
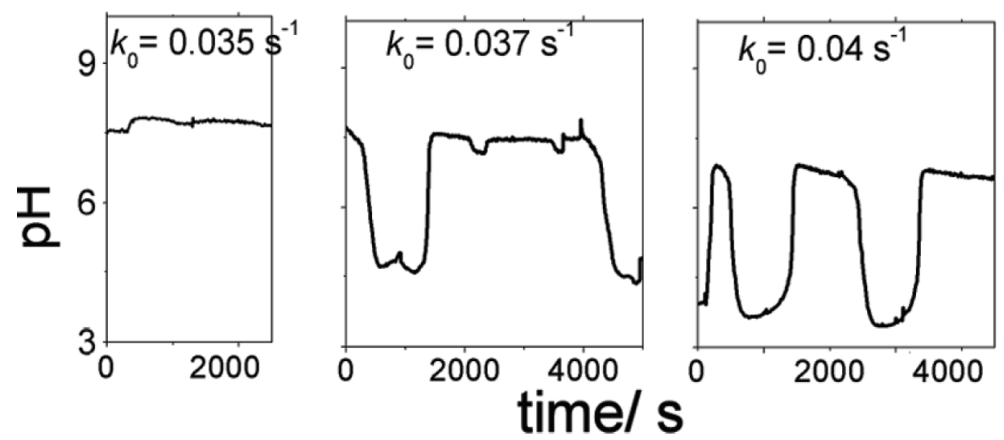

2.1. ábra. Kísérlet során detektált oszcillációs görbék a karbamid-ureáz reakcióban, áramlásvezérelt reaktorban [30].

Tanszékünk munkatársai közül a nemlineáris dinamika tudományterületével először érintôlegesen Novák Mihály és Visy Csaba került kapcsolatba, amikor számos szerves anyag (pl. formaldehid, metanol, hangyasav, etanol, stb.) elektrokémiai viselkedését tanulmányozták és potenciál-idő görbéket regisztráltak. A csupán egy szénatomot tartalmazó vegyületek esetén potenciáloszcillációra figyeltek fel [31], és arra a következtetésre jutottak, hogy ha elég nagy mennyiségú szorbát halmozódik fel, akkor a potenciál hirtelen csökkenése az erősen kötődô komponensek oxidatív deszorpciójához és a felületen végbemenô gyors katalitikus reakcióhoz kötődik.

Nagypál István - aki szintén tanszékünk egykori dolgozója - külföldi tanulmányútja során a klorition-tioszulfátion reakcióval foglalkozott Epstein kutatócsoportjában. Mindketten úgy vélték, hogy ez a rendszer képes órareakcióként viselkedni, de a kísérletekben a klórdioxid termék sárga színe a várakozásokkal ellentétben teljesen rendszertelenül jelent meg az oldatban tíz másodperc és néhány óra eltelte között. Ezen kiszámíthatatlanság miatt az angol terminológiában a „crazy clock reaction” azaz bolondóra-reakció kifejezés terjedt el, mivel megfelelő pufferelés hiányában a kis térrészben felszaporodó protontöbblet hirtelen beindítja a hidrogénionra nézve szuperkatalitikus reakciót [32]. (Érdekesség, hogy a magyar terminológiában is a "bolondóra" elnevezés vált ismertté.) 


\subsection{Térben periodikus struktúrák}

Azokat a folyamatokat, amelyekben az anyag rendezettsége spontán növekszik - entrópiája csökken - önszerveződésnek (self-organization) vagy önrendeződésnek (self-assembly) tekintjük [33]. Az önrendeződés egyensúlyi rendszerekre is jellemző, a képződő struktúra mérete, szimmetriája az alkotó elemek méretének és szimmetriájának a függvénye, gondoljunk csak a micellaképződés vagy a kristályosodás folyamatára. Az önszerveződés egyensúlytól távoli rendszerekben valósul meg, szerepet játszanak benne a térbeli gradiensek, és a kialakuló struktúra mérete nem az egyedi alkotókétól, hanem a kölcsönhatástól függ, ilyenek például a reakció-diffúzió rendszerek.

Léteznek olyan kémiai rendszerek, amelyekben makroszkopikus önszerveződés során térben periodikus struktúrák, mintázatok alakulnak ki, és a kezdeti homogén koncentrációeloszlás valamilyen geometriai alakzattá módosul. A nemlineáris kémiai dinamika ezen rendszereket vezérlő fizikai és kémiai mozgástörvények megismerésével is foglalkozik.

\subsubsection{Frontreakciók, hullámok és Turing-mintázatok}

Bár munkám során mindvégig csapadékot termelô reakciókkal dolgoztam; ahhoz, hogy egy átfogó képet adjak a mintázatokról, nem kerülhetem el a csapadékmentes rendszerben létrejövô struktúrák rövid bemutatását sem. Ha a kémiai reakciót diffúzióval csatoljuk, akkor a térbeli alakzatokat biztosító legegyszerúbb, úgynevezett reakció-diffúzió rendszerek képződnek, amelyekben kémiai hullámok, mintázatok és egyéb geometriai alakzatok jöhetnek létre.

Kémiai front esetében ehhez autokatalitikus reakcióra van szükség, amelynek diffúzióval történő csatolása éles határvonal kialakulását eredményezi a termékek és a reaktánsok között, és az autokatalitikus reakció csupán a vékony térrészben játszódik le jelentôs sebességgel. Luther már 1906-ban megfigyelt az oxálsav kálium-permanganáttal történő oxidációja során ilyen dinamikus mintázatot, de sajnos ezt azóta sem sikerült reprodukálni [34]. Megállapításai azonban még ma is érvényesek: homogén oldatfázisú autokatalitikus reakció esetében jelentkezhet a reakció térbeli tovaterjedése, azaz egy kémiai front kialakulása, ha a sebességi és a diffúzióállandók értékei megfelelôek. A ma ismert frontreakciók száma körülbelül húsz. Ezek közül a klorition-tioszulfátion és a salétromsav-vas(II) reakcióban figyelték meg először Nagypál és munkatársai a közegmozgás hatását [35]. Szegedi munkájának eredménye, hogy a fentiek mellett további savas frontreakciók kivitelezése is tervezhetôvé vált [36]. Biokémiai rendszerben is létrejöhet frontreakció, amennyiben a reakció kinetikája megfelelô. Frontreakciót figyeltek meg a karbamid-ureáz enzimreakcióban is, amelynek során a karbamidot az enzim szén-dioxidra és ammóniára bontja. Ekkor a pH-frontok egyenletes sebességgel haladnak, azonban csak korlátozott ideig, ugyanis bizonyos idő eltelte után az egész Petri-csészényi folyadék a stabilabb, végtermék állapotba alakul [37]. Ezt a frontreakciót arra használták, hogy biokompatibilis polimer hidrogélt állítsanak elô. A folyamat tri- 
tiol báziskatalizált Michael-addíciója poli(etilén-glikol-diakrilát)-ra. A bázist a frontreakció termeli, és így nincsen szükség gyökökre vagy magas hőmérsékletre a folyamat inicializálásához. Továbbá, a polimer hidrolízis útján degradálódik 10-12 óra alatt, ami a kontrollált gyógyszerhatóanyag-leadást is biztosíthatja a későbbiekben [38].

Ha a klorition-tetrationátion reakciót báriumionok jelenlétében hajtjuk végre, akkor a termékként képződő szulfátion a báriumionnal csapadékot képez a front mögött, jelzi annak haladását. Ezt a reakciót adott összetételû́ zselatinban, kellôen kis hőmérsékleten hajtották végre a konvekció kiküszöbölése érdekében. A zselatin alkalmazásának további funkciója instabilitás létrehozása az autokatalizátor (hidrogénion) karboxilát-csoportokkal való részleges megkötése által. Ennek hiányában ugyanis síkfront alakul ki. Mivel a zselatin hőmérséklet- és pH-érzékeny, bizonyos körülmények között szol-gél átalakulás is történhet. Ennek ellenére a modellszámítások, és a megfigyelt centiméteres hullámhossz bizonyítja, hogy a mintázat kizárólag a diffúzív instabilitás következménye. A csapadék indikátorként betöltött szerepén túl, időben állandó mintázat kialakulását is eredményezi, lásd a 2.2. ábrát [39].
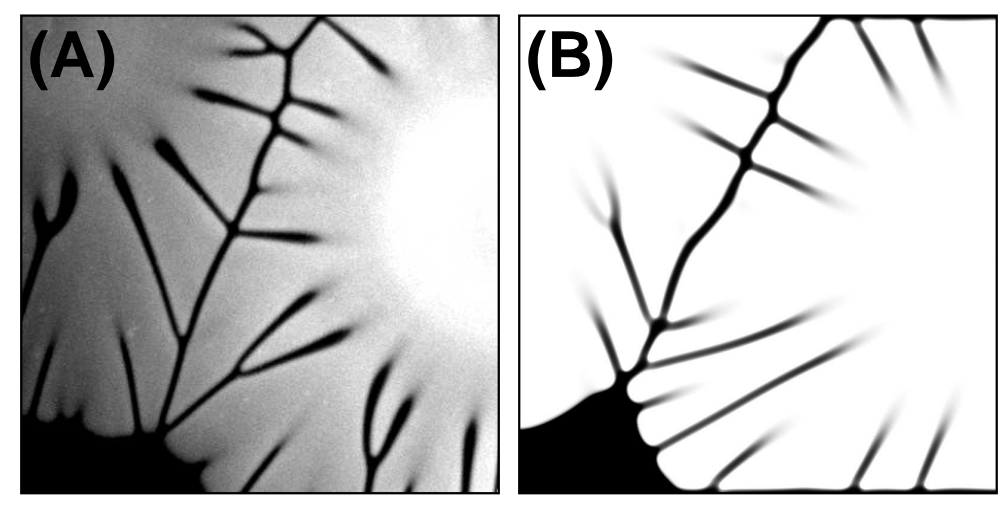

2.2. ábra. Kísérleti felvétel a csapadékkal indikált klorition-tetrationátion reakcióról, a kép mérete $8 \times 8 \mathrm{~cm}$, a körülmények: $3,33 \mathrm{~m} / \mathrm{V} \%$ zselatintartalom és $12{ }^{\circ} \mathrm{C}$ hőmérséklet $(\mathrm{A})$, valamint a modellszámítások eredménye, a kép mérete $9 \times 9 \mathrm{~cm}(\mathrm{~B})$. [39]

A kutatócsoportban töltött idő alatt nekem is volt szerencsém bepillantani a reakciófrontok múködésébe [40]. A klorition-tetrationátion reakció kiindulási elegyébe arany nanorészecskéket keverve az autokatalizátor (proton) reverzíbilis megkötését hajtottuk végre. Így befolyásoltuk a reakciófront stabilitását, azaz a keveredési hosszt és a frontsebességet mind felfelé, mind lefelé haladó front esetén. Azt tapasztaltuk továbbá, hogy a kémhatás változása miatt a nanorészecskék aggregálódnak a termékoldatban.

A kémiai hullámok megjelenése az előzőekkel ellentétben egy gerjeszthetô kémiai reakcióhoz köthetô, amelyben a kezdeti és a végállapot ugyanaz a stabil stacionárius állapot. Zaikin és Zsabotyinszkij 1970-ben mutatták be [41], hogy térben periodikus struktúrák alakulnak ki a gerjeszthető BZ-reakcióelegyben (lásd a 2.3. ábrát): az egyszerúbb céltábla mintázatok mellett spirálok és kettős spirálok is megjelennek. 


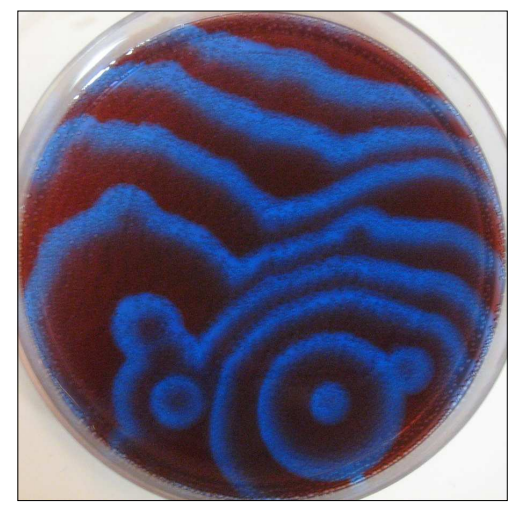

2.3. ábra. Céltáblamintázat kialakulása a BZ-reakcióelegy vékony rétegében. A kísérlet leírása a Függelék I.1. alfejezetében olvasható.

A fordítók rémálma, hogy a front (front) és hullám (wave) az angol nyelvú szakirodalomban gyakran egymás szinonimájaként szerepel, holott e két jelenség alapvető tulajdonságaiban különbözik egymástól. Míg a front két különbözô állapotot különít el a térben, addig a hullám mindkét oldalán ugyanaz az állapot jelenik meg.

Turing angol matematikus már 1952-ben megjósolta, hogy nyílt, homogén rendszerben is lehetséges időben állandósult térbeli szerkezetek kialakulása. Ugyanakkor a jelenség kémiai reakciókkal való kivitelezésére egészen 1990-ig kellett várni, amikor De Kepper és munkatársai kísérletileg is bizonyították a 2.4. ábrán szemléltetett Turing-mintázatok létezését a klorition-jodidion-malonsav rendszerben [42]. Turing-mintázatra máig kevés példát találunk [43]: az előzô klór-dioxid-jód-malonsav analógján kívül csak a ferrocianidjodátion-szulfition reakcióban, vagy amikor a BZ-reakció mikroemulzióban játszódik le. A Turing-mintázatok megtervezésében az áttörés is De Kepper és munkatársai nevéhez füződik, akik nemcsak a tiokarbamid-jodátion-szulfition rendszerben figyeltek meg hatszöges (,pöttyös”) elrendezést, csíkokat, valamint labirintusmintázatot [44], hanem az általános eljárást is ismertették. Mára már háromdimenziós Turing-mintázatokat is sikerült előállítani a BZ-reakcióban, mikroemulzió alkalmazása mellett, melynek vizsgálata tomográfiás módszer segítségével történt [45].

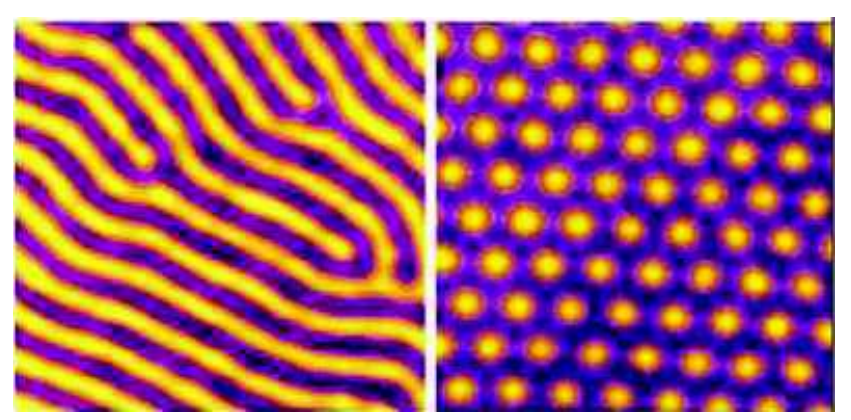

2.4. ábra. Turing-mintázat: csíkok és pöttyök a klorition-jodidion-malonsav kémiai reakcióban [46]. 
A legfrissebb eredményt talán a bromátion-szulfition-ferrocianidion reakcióban érték el, ahol különféle reakció-diffúzió mintázatok alakulhatnak ki, melyeket a beáramló reaktánsok koncentrációja, a hőmérséklet, és a reaktorban lévő gél vastagsága is jelentősen befolyásol. A kálium-ferrocianid és a kénsav koncentrációjának függvényében pöttyök és labirintusmintázat jön létre. Megállapították azt is, hogy az állandósult mintázatok kisebb ionerősségnél figyelhetôek meg [47].

A reakció-diffúzió rendszerek tehát a részecskék transzportját biztosítják, és nem csak nagyméretû struktúrák létrehozására képesek (galaxisok), hanem számos előnnyel rendelkeznek a mikro- és nanostruktúrák kialakításában is. Segítségükkel nagyságrendekkel lecsökkenthető a mintázat, ráadásul a kezdeti koncentrációk, vagy a közeg megválasztásával előre megtervezhető mintázatok is létrehozhatóak [48].

\subsubsection{Csapadékmintázatok kialakulása oldatfázisból}

Bárium-, és stroncium-karbonátok alkáli-szilikát környezetben primitív szervezetekre hasonlító hexagonális és globuláris alakzatokat vesznek fel [49], ami azért nagy jelentőségú, mert ezek a szilikát/karbonát mintázatok tisztán szervetlen eredetú rendszerben jönnek létre. A mintázat alapja, hogy a bárium-karbonát kristály kialakulása során csökken a karbonátionok mennyisége, és így a pH is változik a növekvő kristály környezetében a következô reakciók szerint:

$$
\begin{aligned}
\mathrm{Ba}^{2+}(\mathrm{aq})+\mathrm{CO}_{3}^{2-}(\mathrm{aq}) & \rightleftharpoons \mathrm{BaCO}_{3}(\mathrm{sz}) \\
\mathrm{HCO}_{3}^{-}(\mathrm{aq})+\mathrm{H}_{2} \mathrm{O}(\mathrm{f}) & \rightleftharpoons \mathrm{H}_{3} \mathrm{O}^{+}(\mathrm{aq})+\mathrm{CO}_{3}^{2-}(\mathrm{aq})
\end{aligned}
$$

A bárium-karbonát leválása miatt nô az oxóniumion koncentrációja, ami a kovasav koncentrációjának a növekedéséhez vezet $\mathrm{pH}=9,0$-en és $\mathrm{pH}=10,7$-en a (2.4) és a (2.3) egyenletek szerint:

$$
\begin{aligned}
\mathrm{Si}(\mathrm{OH})_{4}(\mathrm{aq}) & \rightleftharpoons \mathrm{SiO}(\mathrm{OH})_{3}^{-}(\mathrm{aq})+\mathrm{H}_{3} \mathrm{O}^{+}(\mathrm{aq}) \\
\mathrm{SiO}(\mathrm{OH})_{3}^{-}(\mathrm{aq}) & \rightleftharpoons \mathrm{SiO}_{2}(\mathrm{OH})_{2}^{2-}(\mathrm{aq})+\mathrm{H}_{3} \mathrm{O}^{+}(\mathrm{aq})
\end{aligned}
$$

A növekvő bárium-karbonát kristályok körül a kovasav nagy feleslegben lesz jelen, majd a pozitívan töltött részecskék felületére adszorbeálódik érdekes szerkezeteket kialakítva.

Ha nátrium-szilikát-oldatot bárium-klorid-oldattal, és nátrium-karbonát-oldattal elegyítünk, akkor elsőként globuláris alakzatok fejlődnek, majd vékony lemezek jönnek létre és radiális irányban növekedni kezdenek [50]. Ezt követően a lemezek széle feltekeredik, ezáltal szimpla és dupla hélixek is kialakulnak. Azok hullámhossza, szélessége, és periodikussága is bizonyítja a nagymértékű rendezettséget ezekben a struktúrákban. A kétféle csapadék együttes lecsapása önszerveződés révén olyan komplex, háromdimenziós struktúrákat képes létrehozni, melyek korábban csak biológiailag kontrollált kristályosítás során voltak elérhe- 
tőek. A mintázatok kialakulásában alapvető szerepe van a pH lokális, periodikus változásának, melyeket a (2.1) és a (2.2) egyenletek írnak le [51]. A hélixek mellett számos más struktúra is kialakulhat karbonátok és szilikátok együttes csapadékképződéséből: rózsák, virágszirmok, korallok, tölcsérek és vázára emlékeztető alakzatok a néhány mikrométeres skálán [52].

\subsubsection{Csapadékmintázatok elóállítása gélben}

Ha mindenféle makroszkopikus közegmozgást szeretnénk elkerülni, akkor az a legegyszerúbb, ha egy alkalmas gél közeget választunk. Így gondolkozott 1896-ban R. E. Liesegang is, aki érdekes, sávos szerkezetú csapadékképződési reakciót figyelt meg az ezüst-dikromát csapadék előállításakor. Kísérleteiben az egyik reaktánst a gélben oszlatta el, és ebbe a közegbe kívülről diffúzióval juttatta a külsô elektrolitot, így periodikus mintázat kialakulását figyelte meg [53]. Ezt a mintázatot felfedezője után Liesegang-mintázatnak nevezzük, melyben az egyre vastagodó csapadékgyưrúk egymástól egyre távolabb helyezkednek el, és egyre több idő elteltével jelennek meg. A csapadékgyuurúk egymás közti távolsága egy geometriai sort ad, a sávok vastagsága arányos a sávok gélközegtől mért távolságával, és ez a távolság arányos a megjelenés idejének négyzetgyökével. Ezen kísérleti tapasztalatok alapján leírt törvények mellé Lagzi és munkatársai új, nemcsak reakció-diffúzió közegben kialakult csapadékokra érvényes univerzális törvényt javasoltak [54] és levezették, hogy adott idôben a levált csapadék tömege arányos a csapadéksáv tömegközéppontjával.

Liesegang eredeti ezüstion-dikromátion reakcióján kívül számos más, vízben oldhatatlan komponens felhasználásával is előállítható ez a csíkos mintázat (2.5. ábra), például ólomjodid, magnézium-hidroxid, réz-kromát, kobalt-hidroxid, ólom-fluorid, és kobalt-foszfát jelenlétében [55].
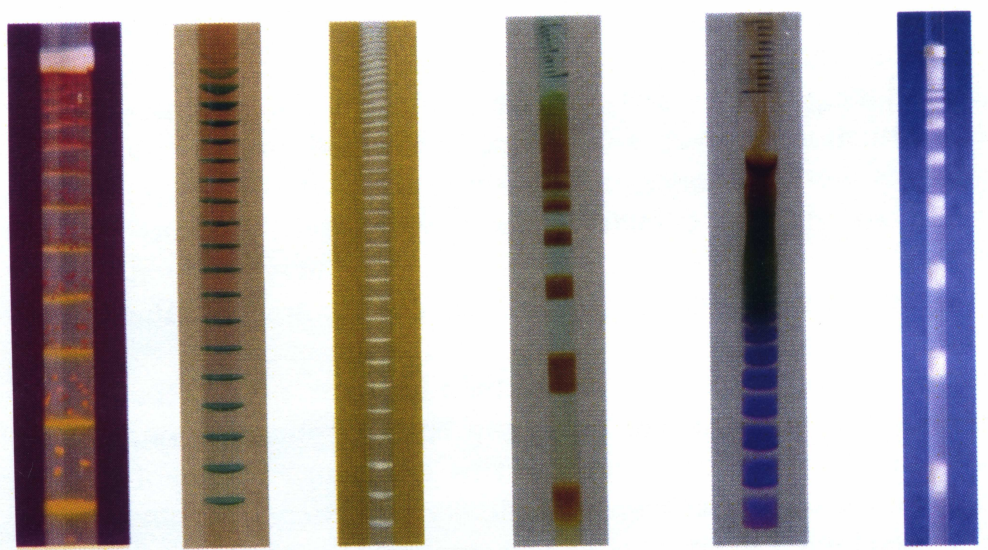

$\mathrm{Pbl}_{2} \mathrm{Co}(\mathrm{OH})_{2}$

\section{$\mathrm{PbF}_{2}$}

$\begin{array}{lll}\mathrm{CuCrO}_{4} & \mathrm{Co}_{3}\left(\mathrm{PO}_{4}\right)_{2}\end{array}$

2.5. ábra. Liesegang-mintázatok különböző csapadékokból [55]. 
Az eredeti, ezüst-dikromát Liesegang-mintázat adott körülmények között kétféle sávos szerkezetet is ki tud alakítani. Vannak nagy, szabad szemmel is jól látható sávok, melyek kisebb sávok sokaságából állnak. A csapadékképződési reakció komplex: elsőként ezüst/ezüst-oxid nanorészecskék képződnek a zselatin redukáló sajátságai miatt. Ezek gócként szolgálnak a rosszul oldódó ezüst-kromát részecskék számára, melyek héjszerúen körbeveszik a nanorészecskéket. Ezek a mag-héj struktúrák alkotják a sok kis sávot. Ezt követôen pedig ezüst-dikromát csapadék válik le a kisebb sávokra, ami ezáltal egy szélesebb sávot alkot, és teljesen más időskálán jön létre [56].

Kálium-jodid és ólom-nitrát reakciójának vizsgálatakor radiális szimmetriával rendelkező kétdimenziós Liesegang-mintázatot mutattak be, amelynél van egy csapadékot tartalmazó belsố rész, és attól távolodva jelennek meg a gyưrúk [57]. Kadmium-klorid és nátriumszulfid reakciójának vizsgálatakor zselatin gélben azonban nem csupán a szabályos kétdimenziós mintázat alakul ki. Bizonyos koncentrációtartományban ezek a sávok felszakadoznak, és a kiürítési zónákra merôleges kiürítési zónák megjelenésével a csíkokat felváltják a pöttyök [58]. Ezüst-dikromát kétdimenziós mintázatában a gél közeg vastagságának módosításával a mintázat hullámhosszának megváltozását figyelték meg [59]. Amikor a reakciófront egy vékonyabb gélből vastagabba halad, akkor a kialakuló csapadékgyưrúk görbülete nő, ellentétes esetben csökken. A kétféle magasságú gél között a gyưrúk transzportja a klasszikus optika fénytörés egyenletével kvantitatíven leírható. Mivel a reakció ionok között játszódik le, az elektromos erőtér hatással lehet a mintázatra: segítségével gyorsítani, és ellentétes elektromos tér hatására lassítani képesek a front haladását [60]. Továbbá, megfelelő elektromos áram alkalmazásával periodikus és előre megtervezett minták is létrehozhatók, valamint az áramerôsséggel a mintázat hullámhossza is szabályozható [61].

Az állandó mintázatok mellett mozgó csapadékmintázatok is léteznek, például a tranziens, újra feloldódó Liesegang-mintázatok. Ilyen esetekben a külső elektrolit diffúziójának irányában (amit a koncentrációgradiens vezérel), gyứrúk kialakulása után, az időben és térben legkorábban kialakult gyưrúk feloldódása következik be [62]. Előfordulhat az is, hogy a terjedő reakciófronttal bizonyos vastagságú csapadékzóna halad végig a csőben [63].

Ha a kémcsövet most Petri-csészére cseréljük, és belső elektrolitot tartalmazó gélre a külső elektrolit oldatából csupán cseppeket helyezünk el, akkor Voronoi-diagramot kapunk. A csepp szélétől elindul a reakciófront, és attól távolodva folytonos csapadékzóna jön létre. A két front találkozásánál csapadékmentes terek, azaz kiürítési zónák alakulnak ki [64]. Az egyszerú Voronoi-diagramok mellett vegyes mintázatokat [55] is létrehoztak a káliumferrocianid belsố elektrolittal rendelkezô gél, valamint a vas-szulfát és a mangán-klorid külső elektrolit oldatcseppjeinek reakciójával (2.6. A ábra). Az oldatcseppeket nátrium-klorid kristályokkal helyettesítve, és belsô elektrolitként módosított felületû arany nanorészecskéket alkalmazva makroszkopikus méretú mintázat alakul ki a 2.6. B ábrán látható módon [65]. Lagzi és munkatársai kimutatták, hogy a szomszédos kristályok távolsága és a kiürítési zóna vastagsága között lineáris kapcsolat van. 

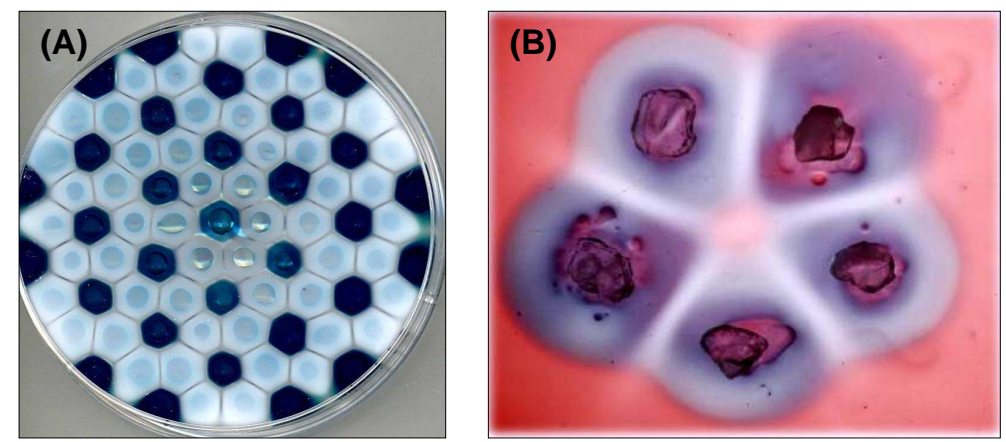

2.6. ábra. Vegyes mintázatú [55] (A), és nátrium-klorid kristályokkal valamint arany nanorészecskékkel kialakított Voronoi-diagram [67] (B).

Gél közegben, periodikus csapadékképződés és feloldódás révén spirál mintázatok is kialakulhatnak. Először poli(vinil-alkohol) gélben, nátrium-hidroxid külsô, és egy nagyságrenddel kisebb koncentrációjú réz-klorid belsô elektrolit alkalmazása során észlelték a 2.7. A ábrán látható jelenséget [66]. Agaróz gélben az alumínium-klorid és a nátriumhidroxid reakciója során hasonló mintázat képződik, melynek kísérleti feltérképezésével Lagzi [68], modellezésével pedig Showalter és munkatársai foglalkoztak [69]. A folyamat a következôképpen zajlik: alumínium-kloridot tartalmazó gélbe kívülrôl nátrium-hidroxid diffundál, csapadék képződik, ami a feleslegben lévő lúg hatására komplexképződés révén feloldódik. Ez a folyamat elegendően vastag gélben a 2.7. B ábrán illusztrált spirálok és dupla spirálok kialakulását okozza.
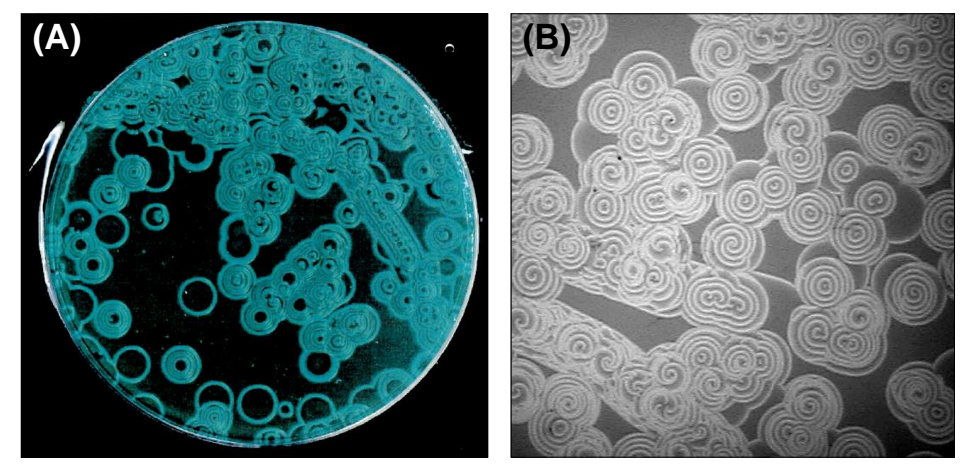

2.7. ábra. Réz-hidroxid csapadék képződése és feloldódása során keletkező spirálok Petricsészében [66] (A), és az általam elkészített alumínium-hidroxid csapadékmintázat (B). A kísérlet leírása a Függelék I.2. alfejezetében olvasható.

Abban az esetben, ha agar gélben higany(II)-kloridot diszpergálnak, és kálium-jodidoldattal indították a reakciót, akkor a sárga színú $\beta$-higany-jodid csapadék leválása, annak a termodinamikailag stabilabb piros színú $\alpha$-módosulattá alakulása, valamint a jodidion feleslegében történő feloldódása az, ami a rendszerben a sok különféle jelenség létrejöttéért felelős. A mintázat a Liesegang-jelenség és a gerjeszthető közegben terjedő hullámok együttes kombinációjaként jelentkezik, így céltáblamintázat és spirál formáját is ölti [70]. 


\subsection{4. Áramlásvezérelt csapadékmintázatok}

A komplex geometriájú fraktálszerkezetek kémiai rendszerekben látható legalapvetôbb megjelenési formája a viszkózus ujjasodás. A kísérlet megvalósítása során nagy viszkozitású folyadékba kisebb viszkozitású folyadékot áramoltatunk, ekkor a határfelület elveszti stabilitását, és elágazó mintázatok jönnek létre [71]. Ha ezt csapadékképző kémiai reakcióval csatoljuk, akkor a kiindulási koncentrációk egy küszöbértéket történô meghaladását követôen a mintázat megváltozik [72]. A kísérletek során Tade és munkatársai nagy viszkozitású folyadékként glicerint, és abban oldott vas(III)-nitrát oldatot, kis viszkozitású folyadékként pedig hexaciano-ferrát(II)-oldatot alkalmaztak. A folyadékok érintkezésekor pillanatszerú csapadékleválást figyeltek meg a határfelületen. Kis koncentrációk esetében a mintázat a csapadékképződés nélküli kémiai reakcióval csatolt viszkózus ujjasodást követte, azonban bizonyos koncentrációtartományban a kis elágazások elnyomását figyelték meg, melyek során a fraktálszerú szerkezet helyett egyenes struktúrák alakultak ki. A legtöményebb oldatok esetében azonban a szál végének közel merőleges elhajlását tapasztalták, melynek oka a csapadék gyors, nagy mennyiségú leválása és felhalmozódása a szál végén, valamint az áramlás ezt követô oldalirányú mozgása (2.8. ábra).
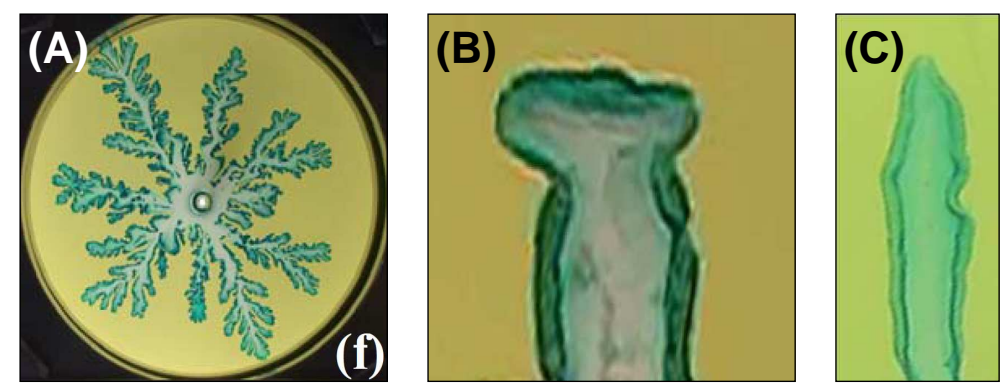

\section{8. ábra. Csapadékképződéssel csatolt viszkózus ujjasodás [72].}

Talán a legszélesebb körben ismert csapadékmintázat a 2.9. ábrán szemléltetett szilikátnövény. A glaubersó felfedezése révén ismertté vált Johann Rudolf Glauber német és holland származású alkimista 1646-ban figyelte meg elsőként, és írta le a jelenséget, melynek német nyelvú fordítása 1661-ben jelent meg [73]. A kert előállítása egyszerú és látványos: vízüvegbe, azaz nátrium-szilikát vizes oldatába, átmenetifém-sókat helyezve a fémiontól függő színú, üreges, elágazó szerkezetú, függőleges, növényre emlékeztető csapadék alakul ki. Az oldatban elhelyezett sókat bevonja egy féligáteresztő csapadékréteg. A fellépő ozmózisnyomás miatt beáramlik a víz, megnô a nyomás, kiszakad a membrán, és a két oldat találkozásánál újra csapadék képződik. Ennek a folyamatnak az ismétlődése során bontakozik ki a vegyészek virágoskertje.

Mivel így egy adott forrásból több cső is nő, nincs lehetôség hosszabb csapadékcsövek kialakítására [74]. Ezt követôen ezért inkább a fémsók oldatainak beáramoltatásával állították elố az egyesével növekvő üreges csöveket. Az oldatok közötti sûrúségkülönbséget eli- 

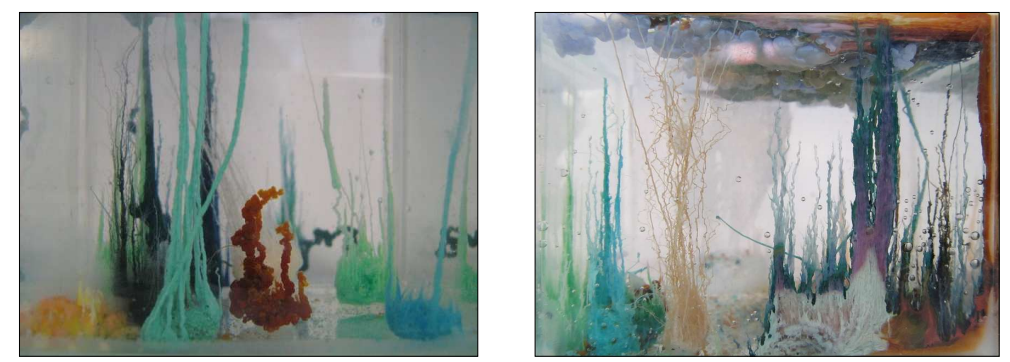

2.9. ábra. Szilikátnövények. A kísérlet leírása a Függelék I.3. alfejezetében olvasható.

minálva mikrogravitációs körülmények között [75] is tanulmányozták a jelenséget kalcium, kobalt-, magnézium-, illetve nikkelsó hozzáadásával. Érdekes szerkezetû üreges részeket, csöveket és ujjszerú képződményeket találtak, amely bizonyítja, hogy az ozmózisnak alapvető szerepe van. Az áramlás jelentőségét buborék segítségével is taulmányozták [76]: nátrium-szilikát-oldatba alulról áramoltattak állandó sebességgel réz-szulfát-oldatot egy vékony csövön keresztül, melynek tetejére egy adott átmérőjú gázbuborékot is elhelyeztek, akkor a buborék nagyságával szabályozható, egységes átmérőjú és egyenes, nem szerteágazó csöveket tudtak létrehozni. Ily módon a technológiailag fontos, fotokatalitikus aktivitást mutató cink-oxid megfelelő átmérōjú és hosszúságú cink-szilikát csövekbe történő szintézise is lehetséges [77], ugyanis a csövek $250^{\circ} \mathrm{C}$-ra történő hevítése során a cink-szilikát mellett a lúgos közegben képződő cink-hidroxid cink-oxiddá alakul, melynek átlagos mérete 10$30 \mathrm{~nm}$.

Steinbock és munkatársai nátrium-szilikát-, és réz-szulfát-oldatokkal végeztek olyan kísérleteket, amelyekben a réz-szulfát- vagy nátrium-szilikát-oldattal feltöltött agaróz gyöngyöket a másik reaktáns oldatába helyezték. A mikrogyöngy körül egy növekvő kolloid réteg alakult ki, melyből függőleges irányban csövek képződtek. A gyöngy sugarának - a felület térfogathoz viszonyított arányának - és az oldatok koncentrációjának változtatása is nagymértékben befolyásolta a csőképződést [78]. A szilikátnövényeket fordított módszerrel is előállították [79], amikor a réz-szulfát-oldatba helyeztek nátrium-szilikát kristályt, vagy felülrôl áramoltattak vékony csőben nátrium-szilikát-oldatot. Az ellenkező sûrúséggradiensnek megfelelően a csapadék az oldatban függőlegesen lefelé nôtt.

Réz-szulfát-oldat áramoltatása nátrium-foszfát-, vagy szilikát-oldatba szintén üreges csövek kialakulását eredményezi [80]. A koncentrációviszonyoktól függően az edény alján frontként terjedő csapadékot, vagy csőképződést figyeltek meg. Kis réz-szulfát koncentráció esetén pedig csak 1-2 cm hosszúságú cső keletkezett, és a további oldat beáramoltatására adott időközönként kisebb csapadékcseppek keletkeztek, melyek a nátrium-foszfát-oldatban függőlegesen felfelé haladtak (a sưrúségviszonyoknak megfelelően). A csövek képződésében sikerült kimutatni az ozmózis szerepét, mikrostruktúrájának vizsgálata során pedig újszerú nanovirágok meglétét igazolták. 
Ha állandó áramlási sebességen nátrium-karbonát-oldatot áramoltatunk kalcium-kloridoldatba zárt edényben, akkor a koncentrációktól, a sưrúségviszonyoktól, és az áramlási sebességtől függő, különféle kalcium-karbonát mintázatok fejlődnek a szabályos körtôl egészen a membrános jellegú, virágra emlékeztető formáig. A szerzők a kísérlet kiértékelése során nagy előrelépést értek el azáltal, hogy kifejlesztettek egy új kiértékelési módszert: szürkeségi skála intenzitás alapján a világos és sötét területek arányából megbecsülték a szilárd fázis mennyiségét a beáramló, elfogyasztott reaktáns mennyiségéhez viszonyítva [81]. Érdekes módon, azon kísérletek során, melyekben a reaktánsok koncentrációja, és az áramlási sebesség is a legnagyobb volt - ahol a legtöbb csapadékot várnánk - alig jelent meg szilárd fázis. Ekkor a beáramló karbonátion széles folyosókat alakít ki, ahol keveredés hiányában csapadék sem képződik [82]. Ha kalciumionokat báriumionokra cseréljük, amely kémiailag hasonló rendszert fog alkotni (pl. a kinetikát tekintve), akkor az a mintázatképződés szempontjából nem jelent problémát. Létrehozható teljesen hasonló mintázat, csak a megfelelő kísérleti paramétereket kell meghatározni. Ha azonban porózus közegben megy végbe e fent említett reakció, és a részecskeméret a pórusmérettel közel azonos nagyságú, akkor az rendkívül eltérô csapadékképződést fog kialakítani [83].

Réz-szulfát-oldat vékony csövön, állandó sebességgel, adott térfogatú nátrium-foszfátoldatba történő áramoltatása a sûrûségkülönbségtôl függô, különböző mintázatok kialakulását eredményezi [84]. Amennyiben a réz-szulfát-oldat sưrúsége nagyobb volt a nátriumfoszfát-oldaténál, akkor a csapadék a Petri-csésze alján képződött kupolaszerú mintázatot alkotva, vagy szokatlan geometriájú, négyszögletes, éles sarkokkal rendelkezô mintázatok keletkeztek (lásd a 2.10. A ábrát). Ellenkező esetben, ha a nátrium-foszfát-oldat sưrúsége volt nagyobb, a kialakuló csapadék az oldat tetejéig növő, függőleges csövekből állt, majd elérve a felszínt, ott vízszintes irányban terjedt tovább. A 2.10. B ábrán is látható, hogy az egyes csövek periodikusan szelvényezettek voltak.
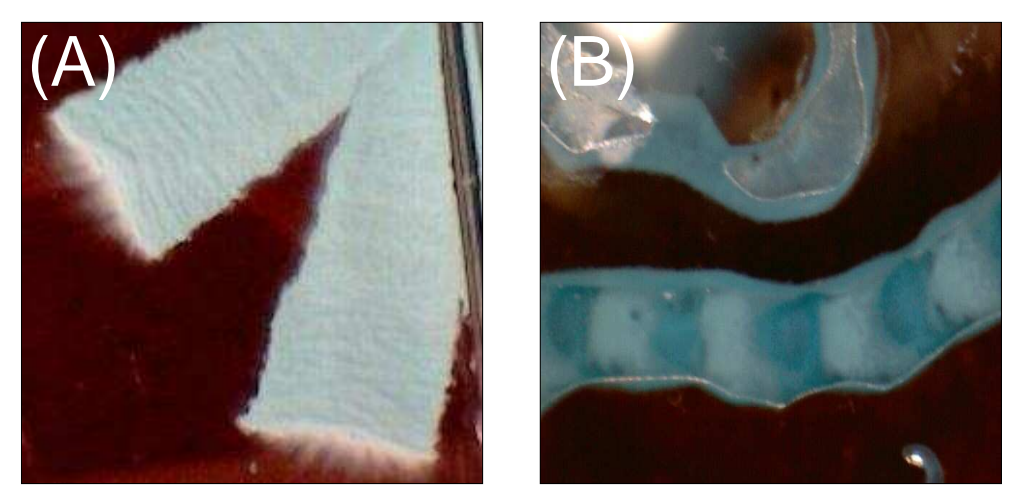

2.10. ábra. A réz-foszfát csapadékban különböző súrúségviszonyok esetén kialakuló mintázatok [84]. 
Szintén szokatlan geometriájú csapadékot tapasztaltak a réz(II)-oxalát csapadék vizsgálatakor [85], attól függetlenül, hogy a nátrium-oxalát-oldatba réz-szulfát pasztillát helyeztek, vagy állandó térfogat-áramlási sebességgel táplálták be a réz-szulfát-oldatot. A pasztilla vagy az oldat betáplálási helye körül kialakult egy vízszintesen terjedő gyưrú, és sugárirányban növekvő méretû szálak képződését figyelték meg. Ez a mintázat is az edény alján képződött, mivel a réz-szulfát-oldatnak nagyobb a sưrúsége, mint az edényben lévő nátriumoxalát-oldaté. A sưrúségviszonyok mellett a létrejött alakzat függött a kezdeti koncentrációktól, valamint a térfogat-áramlási sebességtôl is. A kiszárított csapadék mikrostruktúráját pásztázó elektronmikroszkóppal tanulmányozták: a szálakból vett csapadék 3 mikrométer átmérôjuu és milliméter hosszúságú fonalakból, míg a gyưrúből vett, 7 mikrométer átmérôjû gömbökből állt. Az áramlás hatására tehát nemcsak a makro-, hanem a mikroszerkezet is jelentôs eltéréseket mutatott. Mivel az áramlás mindkét esetben ugyanolyan nagyságrendben volt jelen, más jelenségnek is befolyásolnia kell a mintázatképződést. A réz-oxalát csapadék képződése mellett komplexképződési reakciókat is figyelembe kell vennünk. Csoportunk ezért a réz-oxaláthoz hasonló csapadék- és komplexképződési reakciókkal rendelkező kobalt-oxalát csapadékmintázat kialakulását is feltérképezte [86]. Ugyanis a kobalt-oxalát csapadék képződése mellett a kobaltion hasonló komplexképződési reakciói is lejátszódnak. A 2.11. ábrán a hasonló struktúrájú kobalt-oxalát csapadék és a réz-oxalát csapadék fényképe látható. A beáramlás helyét egy csapadékmentes kör övezi, majd egy rózsaszín csapadékgyưrû következik, melyből jól elkülönülő szálak keletkeznek. A rózsaszín mintázat idôvel színváltozáson megy keresztül, mert fakó narancssárga csapadékréteg jelenik meg, ami a kobalt-oxalát-tetrahidrát-dihidrát átmenethez rendelhetô. A réz-oxalát csapadéktól eltérôen a mikoszerkezetben fonalas struktúra nem jön létre, hanem 15 mikrométer nagyságú hasábok figyelhetôk meg.
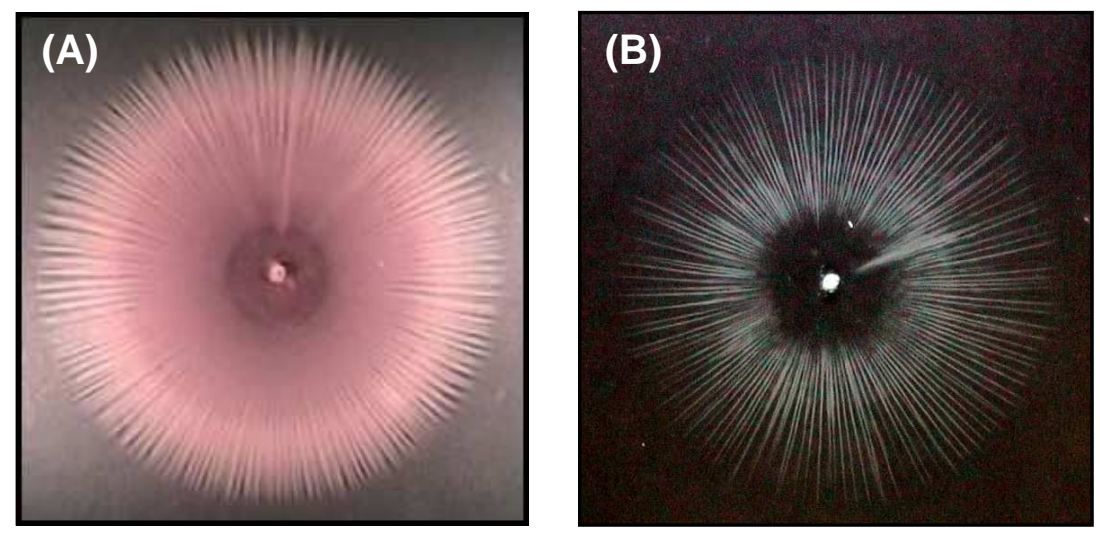

2.11. ábra. A kobalt-oxalát csapadékmintázat [86] (A), és a réz-oxalát csapadékmintázat (B). A kísérlet leírása a Függelék I.4. alfejezetében található. 


\subsubsection{A csapadékmintázatok összehasonlítása}

Számos csapadékképződési reakció alakíthat ki változatos és komplex mintázatokat egyensúlytól távoli rendszerben önszerveződés révén. Ezekben a mintázatokban csupán a szilárd anyag megléte a közös tényező, azonban kialakulásuk hajtóereje, a felépítésük és egyéb jellemzőik eltéróek egymástól. Az eddig bemutatott csapadékmintázatokat öt nagy csoportba sorolhatjuk a 2.1. táblázat szerint. Ezt a táblázatot egy összefoglaló tanulmány alapján készítettem, azonban meg kell említenem, hogy változtatásokat kellett eszközölnöm [87]. Ugyanis a szerzők a kutatócsoportunk által létrehozott szálas csapadékmintázatokat a szilikátnövények kategóriába sorolták. Ezzel a csoportosítással az a probléma, hogy a mintázat kialakulásának hajtóereje alapvetôen eltér a két esetben. Kizárólag az előállítás technikája egyezhet meg, amennyiben a szilikátnövényeket is áramoltatással állítják elő.

2.1. táblázat. A dolgozat irodalmi áttekintőjében tárgyalt csapadékmintázatok típusai.

\begin{tabular}{|c|c|c|c|c|c|}
\hline & $\begin{array}{l}\text { Biomorf } \\
\text { mintázatok }\end{array}$ & $\begin{array}{l}\text { Liesegang } \\
\text { gyúruúk }\end{array}$ & $\begin{array}{c}\text { Mozgó } \\
\text { mintázatok }\end{array}$ & $\begin{array}{l}\text { Szilikát- } \\
\text { növények }\end{array}$ & $\begin{array}{l}\text { Áramlás- } \\
\text { vezérelt } \\
\text { mintázatok }\end{array}$ \\
\hline eredete & 1981 & 1896 & 2000 & 1646 & 2009 \\
\hline hajtóerő & $\begin{array}{l}\text { globális } \\
\text { túltelítettség }\end{array}$ & $\begin{array}{l}\text { lokális } \\
\text { túltelítettség, } \\
\text { diffúzió }\end{array}$ & $\begin{array}{l}\text { lokális túl- } \\
\text { telítettség és } \\
\text { feloldódás }\end{array}$ & $\begin{array}{l}\text { határfelületi } \\
\text { reakciók }\end{array}$ & áramlás \\
\hline csapadék & $\begin{array}{c}\mathrm{Ba}^{2+} \mathrm{Sr}^{2+} \mathrm{Ca}^{2+} \\
+\mathrm{SiO}_{3}^{2-} \mathrm{CO}_{3}^{2-} \\
\mathrm{CO}_{2}\end{array}$ & $\begin{array}{l}\text { változatos } \\
\text { összetételú } \\
\text { csapadék }\end{array}$ & $\begin{array}{c}\mathrm{AlCl}_{3} \mathrm{ZnCl}_{2} \\
\mathrm{NaOH} \\
\mathrm{HgCl}_{2} \mathrm{NaI}\end{array}$ & $\begin{array}{l}\text { változatos } \\
\text { összzetételú } \\
\text { csapadék }\end{array}$ & $\begin{array}{c}\mathrm{C}_{2} \mathrm{O}_{4}^{2-} \mathrm{CO}_{3}^{2-} \\
\mathrm{Ca}^{2+} \mathrm{Mg}^{2+} \\
\mathrm{Co}^{2+} \mathrm{Cu}^{2+}\end{array}$ \\
\hline alakzat & $\begin{array}{l}\text { globuláris } \\
\text { lemezek } \\
\text { hélixek }\end{array}$ & $\begin{array}{l}\text { sávok / 1D } \\
\text { koncentrikus } \\
\text { körök / 2D }\end{array}$ & $\begin{array}{l}\text { szimpla } \\
\text { és dupla } \\
\text { spirálok }\end{array}$ & $\begin{array}{l}\text { üreges } \\
\text { csövek }\end{array}$ & $\begin{array}{l}\text { szálak } \\
\text { korong } \\
\text { virág }\end{array}$ \\
\hline méret & $\mu \mathrm{m}$ & $\mathrm{mm}$ & $\mathrm{mm}$ & $\mathrm{cm}$ & $\mathrm{mm}$ \\
\hline $\begin{array}{l}\text { kiindulási } \\
\text { állapot }\end{array}$ & $\begin{array}{c}\text { oldat } \\
\text { vagy } \\
\text { gázbevezetés }\end{array}$ & $\begin{array}{c}\text { oldat } \\
\text { elhelyezése } \\
\text { a gélen }\end{array}$ & $\begin{array}{l}\text { oldat } \\
\text { elhelyezése } \\
\text { a gélen }\end{array}$ & $\begin{array}{c}\text { injektálás } \\
\text { vagy } \\
\text { kristály }\end{array}$ & injektálás \\
\hline $\begin{array}{c}\text { mikro- } \\
\text { struktúra }\end{array}$ & $\begin{array}{c}\text { poli- } \\
\text { kristályos }\end{array}$ & $\begin{array}{c}\text { kolloid vagy } \\
\text { kristályos }\end{array}$ & ismeretlen & $\begin{array}{c}\text { amorf vagy } \\
\text { kristályos }\end{array}$ & $\begin{array}{c}\text { kristályos } \\
\text { vagy amorf }\end{array}$ \\
\hline
\end{tabular}

Napjainkra oszcilláló reakciók, térben és idôben állandó szerkezetek sorát ismerik, foglalkoznak megtervezésükkel, előállításukkal, modellezésükkel és mechanizmusuk felderítésével. Ezen struktúrák kialakulásának termodinamikai leírásáért 1977-ben Ilya Prigoginenek [88], míg 2007-ben a szilárd felületeken végbemenő kémiai folyamatok tanulmányozásáért Gerhard Ertlnek [89] ítélték a kémiai Nobel-díjat. Hazánkban 1990-ben Széchenyidíjjal jutalmazták e tudományterület képviselőit: Kôrös Endrét, Noszticzius Zoltánt és Orbán Miklóst [90]. 


\subsection{A kalcium-oxalát és a kalcium-karbonát}

A kalcium-oxalát ásványok közül leggyakoribbak a hidratált formák, mint például a monohidrát whewellit (COM), a dihidrát weddellit (COD) [91], valamint a trihidrát caoxit (COT) [92]. Hazánkban Recsk közelében, hidrotermális ércesedésekben az egy mol kristályvizet tartalmazó whewellit fordul elő ásványi formában. Emellett megtalálható az élő szervezetekben is, például az emberekben vesekövekként, valamint több, mint 250-féle növényben, többek között a rebarbara és a paszuly leveleiben is. A vesekövek nagy mennyiségben, kb. 70-80\%-ban kalcium-oxalát monohidrátot tartalmaznak, melyet különböző nagymúszeres szerkezetvizsgáló módszerekkel azonosítottak [93-95]. A vesekövek tartalmazhatnak a Liesegang-gyúrúkhöz hasonló kalcium-oxalát koncentrikus csapadékgyuurúket [96], ezért feltérképezték két dimenziós agar-agar biogélben a csapadékmintázat kialakulását. Mivel s ritkaföldfémeke alkalmasak lehetnek hozamnövelésre, egyre nagyobb jelentőségú ezek élő szervezetekre gyakorolt hatásának vizsgálata. Kimutatták, hogy a kalciumion tulajdonságaihoz hasonló $\mathrm{Er}^{3+}, \mathrm{Gd}^{3+}, \mathrm{La}^{3+}$ ionok közül csak az elsô segíti elő a kalcium-oxalátmonohidrát kristály létrejöttét, de a koncentrikus mintázat kialakításában nincs jelentôsége. A növények közül a Phaseolus vulgaris (közönséges paszulybab) leveleiben lévő kalciumoxalát kristályok méretének növekedését is tanulmányozták. Energiadiszperzív röntgen analízissel sikerült azt bizonyítaniuk, hogy normális és magas kalciumtartalmú növények leveleiben a kalcium-oxalát kristályok sưrüsége közel harmadára, felére csökkent ólom- vagy cinkionok jelenlétében [97].

A kalcium-karbonát számos különböző kőzet és ásvány összetevője, legismertebb ezek közül a mészkô, illetve a kalcium-, és magnézium-karbonátból álló dolomit. Tisztán trigonális kalcit, rombos aragonit, vagy hexagonális vaterit formában található meg (2.12. ábra). A kalcium-karbonát alkotja a puhatestúek vázát, a csigák házát, vagy a kagylók héját, de a tojás héját is kb. 95\%-ban az építi fel. Vesekövekben is megtalálható a kalcium-karbonátnak mindhárom előbb említett változata [98].

Megfelelő közeg megválasztásával, pl. nanorészecskék hozzáadásával, a kalcit módosulat jellegzetes romboéderes formáját megváltoztathatjuk. Ennek oka, hogy a kristályok felületére nem specifikusan adszorbeálódnak a nanorészecskék, ezáltal késleltetve azok növekedését. Adott kalcium-karbonát koncentráció mellett a nanorészecskék mennyiségének növelésével kisebb kristályok alakultak ki: $\mathrm{pH}=11$ kémhatású oldat esetén a részecskék felületén 5-6 nm vastag monoréteg jön létre, $\mathrm{pH}=9$ esetén már 50 nm-re nő a borítottság, míg $\mathrm{pH}=8,5$ esetén piramis formájú struktúrák borítják a kalcit jellegzetes romboéderes alakját [99]. A kristályos kalcium-karbonátok mellett a termodinamikailag nem stabil amorf fázis is széles körben elterjedt az élôvilágban, például a puhatestúek külsô vázában, tengerisünökben, kagylóhéjakban [100]. Az amorf kalcium-karbonát előállítására több módszer ismeretes, azonban a kristályos formává alakulás rövid időn belül bekövetkezik. Chujo és munkatársai egy újszerú módszert javasoltak [100], amellyel akár hetekig stabil monodisz- 
perz gömbök hozhatóak létre. Az eljárás lényege az ammónium-karbonát oldat $1 \mathrm{~cm}^{3} \cdot \mathrm{h}^{-1}$ sebességú csepegtetése a kalcium-klorid és a poliakrilsav lassan kevertetett elegyébe. A kialakult amorf módosulat stabilitása az alkalmazott koncentrációk és az áramlási paraméterek mellett a poliakrilsav moláris tömegével is összefüggést mutat.
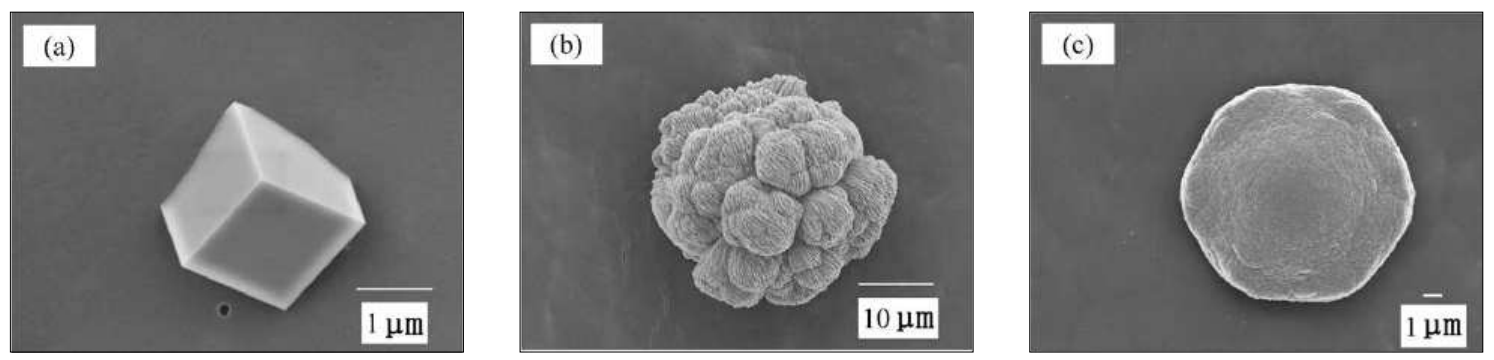

2.12. ábra. A kalcium-karbonát különböző módosulatai: kalcit (A), és különböző vaterit gömbök (B-C) [101].

Ha van egy jól termosztált, jól kevert reaktor nátrium-karbonát-oldattal és oltókristállyal, majd ebbe kalcium-klorid-oldatot vezetnek, akkor az áramlási sebességtől, a kristályok méretétôl, és mennyiségétôl függően különböző morfológiájú vaterit alakul ki [102]. Például $30{ }^{\circ} \mathrm{C}$-on, $2000 \mathrm{rpm}$ keverési sebesség mellett a szabályos gömb alakú módosulat keletkezik, míg oltókristállyal, ugyanezen körülmények között már a kevésbé szabályos, duplán növő részecskék a gyakoribbak. Ha azonban az áramlási sebességet két nagyságrenddel megemeljük, akkor az egységes részecskeméret-eloszlást felváltja az inhomogén.

Azt, hogy egy-egy molekuláris jellemző milyen nagymértékben képes hatni a kristályszerkezetre, egy egyszerû módszerrel mutatták be [103]. Kalcium-kloridhoz L-, és D-aszparagint vagy L-, és D-glutaminsavat, valamint nátrium-karbonát-oldatot adtak. Ekkor a kialakuló vaterit apró lemezkékből felépülô részecskéket eredményezett, melyek az L-enantiomerek esetén az óramutató járásával ellentétes irányban rendeződtek, míg D-enantiomerek adagolásával az óramutató járásával megegyezô hierarchikus struktúrákat alakítottak ki. Vizsgálataik során fény derült rá, hogy a királis aminosavak a nanoméretú lemezkék közé ágyazódnak be. Itt akirális szimmetrikus vaterit felületre adszorbeálódnak, ami miatt egy toroidális, azaz gyûrû́szerû forgásfelületet biztosítanak a lemezkék növekedésének.

A hang, jelen esetben az ultrahang a kémiai szintézisek során is szerepet kaphat [104]. Egy egyszerú módszer segítségével, azaz ulrahanggal segített kristályosítással, metastabil vaterit nanorészecskék állíthatóak elő. A módszer előnye, hogy a kristályosodási folyamat sokkal gyorsabban végbemegy (csökkent reakcióidő), továbbá, hogy kisebb részecskék keletkeznek, mint a hagyományos, mágneses kevertetést alkalmazó eljárás esetén.

Az ureáz több szempontból is kifejezetten érdekes biokatalizátor. Egyrészt ez volt a legelsô enzim, amelyet kikristályosítottak [105], másrészt a szelektivitás kitûnő példája: múködése során csupán a karbamiddal reagál, azt ammóniára és szén-dioxidra bontja. A keletkező szén-dioxid egy része karbonátionná alakul az oldatbeli egyensúlyok végbemenetele 
során, ami kalciumionokkal csapadékba vihető. Az enzim többféle baktériumban is megtalálható, és ezen változatosság miatt számos végterméke, illetve végkifejlete lehet a reakcióknak. Ennek egyik példája, amikor a kísérletek során üreges, vaterit módosulata alakul ki a kalcium-karbonátnak, melyet mikroszkópiás és Röntgen-diffrakciós mérések segítségével azonosítottak. Ugyanebben a kísérletben báriumionokkal is elvégezhetô a lecsapás, azonban akkor amorf, hosszúkás bárium-karbonát csapadékrészecskék keletkeznek [106].

Azt, hogy egyre nagyobb az érdeklődés a kalcium-karbonát iránt, mutatja ipari alkalmazásának széles köre: adalékanyaga kozmetikumoknak, cementnek és üvegeknek, valamint élelmiszeripari termékeknek is [107]. Biokompatibilis tulajdonságának köszönhetôen fogápolási termékekben és a gyógyszeriparban is használják: amellett hogy nem toxikus, biodegradábilis is. Alkalmazzák gyógyszerek töltőanyagaként, és bizonyos módosulatait a kontrollált hatóanyag-leadás érdekében [108-110]. A különböző kristályméret és morfológia döntôen meghatározza az oldatban való stabilitást, a keménységet, a kristályosodást és a feloldódást, így a lehetséges alkalmazásokat is. Például épületek és szobrok restaurálási munkálataihoz a kalcit forma a legkedvezôbb [111], míg gyógyszerek hatóanyagának szabályozott leadásához a pórusos szerkezetút ajánlják. 


\section{3. fejezet}

\section{Célkitúzés}

Kutatócsoportunk a korábbiakban vizsgált réz- és kobalt-oxalát csapadékokban áramlásvezérelt körülmények között érdekes, az edény alján szétterülő, szálak sokaságából álló mintázatot talált, ami egy belső csapadékmentes körről indul. Kimutatták a mintázatképződésben a közegmozgás szerepét, mely a csapadékok mikrostruktúrájára is hatással volt. A mintázatvezérlés okainak tisztázására további csapadékok vizsgálatára volt szükség, ezért úgy döntöttünk, hogy a kalciumsók közül a kalcium-oxalát és a kalcium-karbonát mintázatának feltérképezésével foglalkozom majd. A korábbi csapadékokkal ellentétben, ezek a kalciumion-tartalmú csapadékok gyors, pillanatszerú csapadékképzési reakciókban vesznek részt. Munkám célja, hogy a kalcium-oxalát és kalcium-karbonát csapadékmintázatot jellemezzem, és azt vizsgáljam, hogy a csapadéknak melyik polimorf módosulata alakul ki.

A kalcium-karbonát elóállítására sokféle technika létezik az irodalomban és a természetben egyaránt. Mi egy olyan módszert szerettünk volna kipróbálni, amelyben enzim termeli a csapadékképződési reakció egyik szereplőjét, a karbonátiont. Ehhez a karbamid-ureáz enzimreakciót használtuk fel, és kalcium-kloriddal egészítettük ki. Terveink között szerepel, hogy órareakcióban is vizsgáljuk ennek a reakciónak a módosulását a kalciumionok hatására. 


\section{4. fejezet}

\section{Kísérleti rész}

\subsection{Oldatkészítés}

\subsubsection{Az áramlásvezérelt kísérletekhez}

Az oldatokat pontos tömegbeméréssel készítettem analitikai tisztaságú reagensekből, ioncserével és fordított ozmózissal tisztított $10 \mu \mathrm{S} \cdot \mathrm{cm}^{-1}$ tisztaságú víz felhasználásával (a dolgozat további részében az egyszerűség kedvéért a tisztított víz fogalmat fogom használni). A kalcium-klorid oldhatóságát figyelembe véve a két kristályvizet tartalmazó szilárd kalciumkloridból (Scharlau) 1-4,0 mol · dm ${ }^{-3}$ koncentrációjú oldatokat készítettem [112]. Hasonló megfontolások alapján [112] $0,01-0,1 \mathrm{~mol} \cdot \mathrm{dm}^{-3}$ koncentrációjú nátrium-oxalát-oldatot állítottam elô szilárd nátrium-oxalátból (VWR), és $0,01-0,1 \mathrm{~mol} \cdot \mathrm{dm}^{-3}$ koncentrációjú nátrium-karbonát-oldatot szilárd, 10 kristályvizet tartalmazó nátrium-karbonátból (Spektrum 3D). A nátrium-oxalát-, és a nátrium-karbonát-oldatok kémhatását nátrium-hidroxid, és sósavoldatokkal állítottam be Orion 420 típusú $\mathrm{pH}$-mérôt $(\mathrm{pH} \pm 0,05)$ alkalmazva. A reagenseket minden esetben közvetlenül a mérés előtt készítettem el, mert kémhatásuk savasodott a levegő szén-dioxid-tartalmának beoldódása következtében. A viszkozitás és a sûrűség változtatásához szilárd nátrium-kloridot (Molar), szilárd poli(vinil-alkohol)-t (PVA, Sigma-Aldrich), illetve 50 tömegszázalékos poliakrilamid-oldatot (PAA, Aldrich) és glicerint (VWR) alkalmaztam, melyeket a kalcium-kloriddal együtt oldottam fel. A nagy viszkozitású folyadékokat a nagyobb pontosság érdekében nem térfogat, hanem tömeg alapján mértem be.

\subsubsection{Az enzimreakcióhoz}

Az enzimreakcióhoz a következő oldatokat készítettem, és elegyítettem a megfelelő sorrendben: I) tisztított víz; II) kalcium-klorid (Sigma Aldrich, CAS 10035-04-8); III) sósav (Molar); és IV) karbamid (Sigma Aldrich, CAS 57-13-6). Végül, a reakció iniciálása érdekében V) az ureáz enzim (Sigma Aldrich gyártójú, III. típusú, kardbabból kivont Canavalia ensi- 
formis) oldatát adtam a jól kevert elegyhez. A kontrollkísérletekhez ammónium-karbonátoladtot (Reanal) készítettem.

\section{Az enzim aktivitásának meghatározása}

Az enzim aktivitását a gyártó által javasolt és alkalmazott módszer szerint határoztam meg [113]. Ennek a módszernek a lényege, hogy 1 mikromoláris egység (melynek jele: u) 1 perc alatt $1 \mu \mathrm{mol} \cdot \mathrm{dm}^{-3}$ ammóniát szabadít fel a karbamidból semleges kémhatású oldatban $25^{\circ} \mathrm{C}$-on. Ebből az összefüggésből származtatott értéket titrálás útján tudom meghatározni.

A teszthez $25{ }^{\circ} \mathrm{C}$-on, nátrium-foszfát pufferrel (Fluka, $c=0,75 \mathrm{~mol} \cdot \mathrm{dm}^{-3}$ ) beállított, semleges kémhatású oldatban karbamidot $\left(c=0,5 \mathrm{~mol} \cdot \mathrm{dm}^{-3}\right)$ és marha szérumalbumint (Sigma, $\rho_{o a}=0,05 \mathrm{~m} / \mathrm{V} \%$ ) oldottam fel. Az ureáz enzimből nátrium-foszfát pufferrel $300 \mathrm{u} \cdot \mathrm{cm}^{-3}$ töménységú oldatot készítettem. A titrálás végpontjelzéséhez tisztított vízzel $p$-nitrofenol-oldatot (Reanal, $\rho_{o a}=4 \mathrm{mg} \cdot \mathrm{cm}^{-3}$ ) készítettem. Ezeket az oldatokat $25^{\circ} \mathrm{C}$-on, vízfürdőben temperáltam.

Az aktivitás meghatározása során az oldatokat a 4.1. táblázatnak megfelelő sorrendben elegyítettem, de az indikátor hozzáadása előtt a vízfürdőben $25^{\circ} \mathrm{C}$-on az oldatot öt percen keresztül kevertettem.

4.1. táblázat. Az enzimaktivitás meghatározása. A titrálandó elegyhez bemérendő térfogatok.

\begin{tabular}{ccccc}
\hline \hline & $\begin{array}{c}\text { karbamid } \\
\left(\mathrm{cm}^{3}\right)\end{array}$ & $\begin{array}{c}\text { ureáz } \\
\left(\mathrm{cm}^{3}\right)\end{array}$ & $\begin{array}{c}\text { indikátor } \\
\left(\mathrm{cm}^{3}\right)\end{array}$ & $\begin{array}{c}\text { ureáz } \\
\left(\mathrm{cm}^{3}\right)\end{array}$ \\
\hline vak & 1 & - & 0,2 & 0,1 \\
teszt & 1 & 0,1 & 0,2 & - \\
\hline \hline
\end{tabular}

A titrálás során titráló oldatnak $0,1 \mathrm{~mol} \cdot \mathrm{dm}^{-3}$ sósavoldatot alkalmaztam, melyet tisztított víz felhasználásával készítettem el. A sósavoldat csepegtetését addig folytattam, amíg az oldat színe sárgából színtelenre változott. Ezt a vak oldat estében egyszer, a mintán pedig háromszor végeztem el. A kiértékelés során figyelembe vettem a $\Delta V_{\mathrm{HCl}}=V_{\text {teszt }}-V_{\text {vak }}$ kivonást. Ezek alapján az aktivitást oldatra viszonyítva az ,egység $\cdot \mathrm{cm}^{-3}$ ” tömegre átszámítva pedig ,egység · $\mathrm{g}^{-1}$ ” mértékegységben kaptam meg.

\subsection{Kísérleti elrendezés}

\subsubsection{A csapadékmintázatok tanulmányozása}

Kísérleteimet egy 24,2 cm × 24,2 cm méretú, négyzet alapú, 5,0 cm magas üvegedényben végeztem [114-116], melyet $250 \mathrm{~cm}^{3}$ térfogatú nátrium-karbonát vagy nátrium-oxalát- 
oldattal töltöttem fel. A négyzet alapú edény alján középre egy lyukat fúrtunk, melyet szilikonragasztóval lezártam. Ezen a tömítésen keresztül vezettem be a kalcium-klorid-oldatot az edénybe egy 0,8 mm belsô átmérôjû vérvételi tûvel. A tûhöz egy 0,25 mm, nagyobb térfogatáramlási sebességek eléréséhez egy $0,57 \mathrm{~mm}$ belső átmérôjú Tygon csövet csatlakoztattam, és az oldatot ISMATEC Reglo perisztaltikus pumpa segítségével áramoltattam az edénybe a 4.1. ábrán látható módon.

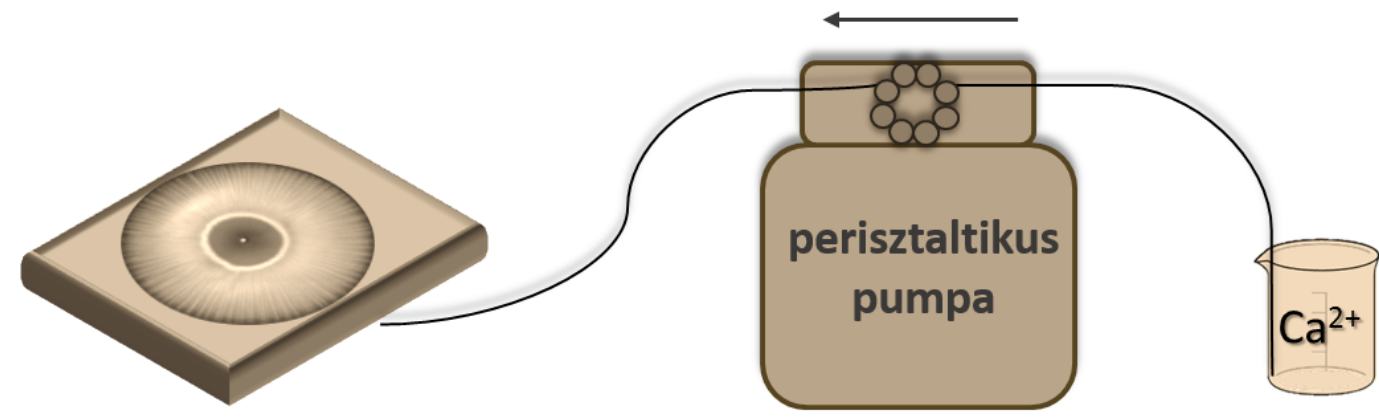

4.1. ábra. Az áramlásvezérelt kísérletek során alkalmazott kísérleti elrendezés sematikus ábrázolása.

A csapadék mintázatának kialakulását Unibrain 1394 Innovators digitális kamerával követtem, és külsô megvilágítást alkalmaztam. Minden kísérlet előtt a reakcióedényt vízszintes helyzetbe állítottam, ellenkező esetben aszimmetrikus csapadékmintázat alakult ki.

Referencia mintaként jól kevert körülmények között kialakult csapadékokat is vizsgáltam, melyeket főzôpohárban mágneses kevertetés közben állítottam elő. $\mathrm{Az} 50 \mathrm{~cm}^{3}$ térfogatú, $0,2 \mathrm{~mol} \cdot \mathrm{dm}^{-3}$ koncentrációjú nátrium-oxalát-, és nátrium-karbonát-oldatba csepegtettem $50 \mathrm{~cm}^{3}, 0,2 \mathrm{~mol} \cdot \mathrm{dm}^{-3}$ koncentrációjú kalcium-klorid-oldatot, valamint fordított adagolással is elvégeztem a kísérletet folyamatos kevertetés közben.

\subsubsection{Az enzimreakció tanulmányozása}

A reakció előrehaladásakor jelentős kémhatásváltozás történik, amelyet pH-mérô elektród (VWR) segítségével detektáltam. A keletkező csapadékot digitális kamerával (Unibrain Ultra Compact Firewire-400 camera) követtem nyomon $20 \mathrm{~cm}^{3}$ térfogatú oldatban, házi készítésû́ programok alkalmazásával. A kísérleteket kétféle reakcióedényben hajtottam végre: egy zártban, illetve egy, a külvilág felé nyitott cellában. A reakcióedény a nyílt felszínú kísérletek során $3 \times 3 \mathrm{~cm}$ alapterületú, $9 \mathrm{~cm}$ magas síküveg oldalfalakkal határolt üvegedény volt. Ezáltal nincs görbület, mely szórná a fényt, és zavarná a szürkeségi skála értékeinek meghatározását. Zárt reakcióedényként egy folytonosan kevert plexi reaktort használtam. Ezekben a folyamatos keverést mágneses keverôvel és keverôbottal biztosítottam (Velp Scientific Microstirrer). 


\subsection{Alkalmazott múszzerek és eszközök}

\subsubsection{Termogravimetria}

Termogravimetriás (TG) analízis során a szilárd por programozott hevítésekor bekövetkező tömegváltozását egy érzékeny analitikai mérleg detektálja. A kapott adatok alapján a minta anyagi minőségére következtethetünk. Az általunk vizsgált csapadékok esetén ezt a módszert a kalcium-oxalát különböző hidratált formáinak megkülönböztetésére alkalmaztuk.

A méréseket MOM Derivatograph Q-1500D és Mettler Toledo TGA/SDTA 851 ${ }^{e}$ típusú készülékkel végeztük. A mintákat kerámia tégelyben hevítettük, miközben referenciának $\alpha$ - $\mathrm{Al}_{2} \mathrm{O}_{3}$-at használtunk. Analitikai mérlegen $100 \mathrm{mg}$ mintát mértünk be, majd $5^{\circ} \mathrm{C} \cdot \mathrm{min}^{-1}$ lineáris fútési sebességgel fútöttük fel levegó atmoszférában $25^{\circ} \mathrm{C}$-ról $1000{ }^{\circ} \mathrm{C}$-ra. A minta elôkészítése úgy történt, hogy az áramlásvezérelt kísérlet során képződött csapadékot hagytuk ülepedni majd az oldat jelentôs részletét pipettával eltávolítottuk. A maradék folyadék az egy napos állás közben elpárolgott. A jól kevert rendszerben előállított csapadékot dekantáltuk, majd a száradást követően vizsgáltuk.

\subsubsection{Infravörös spektroszkópia}

Az infravörös spektroszkópiás (IR) eljárás során a mintát az elektromágneses sugárzás infravörös tartományába esố hullámhosszúságú fénnyel sugározzuk be. Az abszorpciós technika alkalmazásakor a minta sajátrezgéseinek megfelelő energiájú fényt nyeli el, amiből a minőségre következtethetünk. Az IR-spektroszkópia a vizsgált szilárd mintáinkban a kalciumklorid só jelenlétének kizárását tette lehetôvé.

A szilárd minták elnyelési színképeinek felvételét egy Bio-Rad Digilab Division FTS 65A/896 FTIR-spektrométerrel végeztük. DTGS típusú detektort, és Harrick Meridian Split Pea Diamond ATR-feltétet alkalmaztunk. A spektrumokat $4 \mathrm{~cm}^{-1}$ optikai felbontással, a $400-4000 \mathrm{~cm}^{-1}$ tartományban rögzítettuik, és a végsô színkép 256 interferogram átlagaként adódott.

\subsubsection{Raman-spektroszkópia}

Ha a monokromatikus lézerfény segítségével megvilágított mintán a foton rugalmatlanul szóródik, akkor a minta rezgési és forgási energiája változhat, és a visszaszóródó fény minőségi információt szolgáltat. Ezen módszer segítségével megkülönböztettük a vizsgált minták különböző hidratált formáit, illetve polimorf módosulatait.

Mintáink szerkezeti vizsgálatait egy Bio-Rad Digilab Division Dedicated FT Raman típusú készülékkel végeztük. Méréseinkhez 290 mW teljesítményú ADLAS-321 Nd:YAG típusú lézert, és folyékony nitrogénnel hûtött Ge-detektort használtunk $180^{\circ}$ adatgyújtési

szög mellett. A spektrumokat $4 \mathrm{~cm}^{-1}$ optikai felbontással, a $100-3600 \mathrm{~cm}^{-1}$ tartományban 
vettük fel. Egy színképet 1024 interferogram átlagaként kaptunk. A kiszárított mintákat egy házi készítésú mintatartóba helyeztük. A mintatartó egy kb. $1 \mathrm{~cm}$-es korong alakú réztömb, amelynek közepében egy 1,4mm átmérőjú mélyedés található, ahová a mintánkat helyeztük. A színképeken az alapvonal korrekcióját, majd a sávokra Gauss-Lorentz-görbe illesztését a fityk programmal hajtottam végre [117].

Az egyedi részecskék spektrumát THERMO DXR Raman-mikroszkóp segítségével rögzítettuik. A készülék térbeli felbontása $\sim 1 \mu \mathrm{m}$, a mérésekhez $\lambda=532 \mathrm{~nm}$ hullámhosszúságú lézert alkalmaztunk; a lézerteljesítmény 1-10 mW volt, és 30 spektrumot átlagoltunk a végső színkép létrehozása érdekében. A minta elkészítése során vékony üveg fedőlemezeket helyeztem a reakcióedény belsejébe, amelyek felületén végül a csapadék kialakult. A mintázat különböző területeinél lévô üveglemezeket összegyújtve, egy nap száradást követôen vizsgáltuk az egyedi részecskéket.

Az enzimreakcióból származó mintákat G4-es szúrôn szűrtem, majd tisztított vízzel átmostam és kiszárítottam a mérések előtt.

\subsubsection{Spektrofotometria}

Turbiditásméréseket egy ultraibolya-látható (UV-Vis) spektrofotométer segítségével végeztünk (VWR, UV3100-PC), $2 \mathrm{~cm}^{3}$ térfogatú keverékben, $\lambda=400 \mathrm{~nm}$ hullámhosszon, $25^{\circ} \mathrm{C}$ hőmérsékleten.

A küvettákban a folyamatos kevertetést és a levált csapadék ülepedésének megakadályozását Starna 'Spinette' Electronic Cell Stirrer SCS 1.22 miniatûr mágneses keverővel biztosítottam.

\subsubsection{Mikroszkópiás vizsgálatok}

A legtöbb általunk vizsgált részecske mérete abba a mérettartományba esik, hogy optikai mikroszkóp segítségével is tanulmányozható. Ezekhez a mérésekhez Optika B600 TIFL mikroszkópot 4, 10, 20 és 40-szeres nagyítással alkalmaztam. Ez a nagy területú edényben kialakult mintázat reprezentatív jellemzését tette lehetővé számunkra.

A pásztázó elektronmikroszkóp (SEM) azonban már jóval szebb, és nagyobb felbontású felvételek készítésére képes. A képalkotás alapja, hogy egy vékony elektronnyaláb tapogatja le a megfigyelni kívánt területet. Mintáinkban a felületi morfológia vizsgálata mellett méreteloszlás meghatározására is szolgált a Hitachi S4700 típusú pásztázó elektronmikroszkóp. Segítségével szekunder elektron detektálási üzemmódban ( 2 db Everhart Thornley típusú másodlagos elektron detektor), $10 \mathrm{kV}$ gyorsítófeszültségnél vizsgáltuk a kristályokat. A korábban leírt mintaelôkészítési eljárás során keletkezett szilárd anyagot rászórtuk a mindkét oldalán tapadó felülettel bíró vezetô szénszalagra, bizonyos esetekben pedig lenyomatot készítettünk a mintáról. A szénszalagot a mintatartó korongra ragasztottuk fel, majd a mintákat vékony aranyréteggel vontuk be vezető felület kialakítása érdekében. 


\subsubsection{A sứrúség és a viszkozitás meghatározása}

Az egyes oldatok sưrűségét úgy határoztam meg, hogy lemértem a száraz lombik, és az oldattal töltött lombik tömegét, majd a különbségüket elosztottam a lombik térfogatával, más esetekben Anton Paar DMA 500 típusú sürüségmérőt használtam.

A pormintáink sưrűségét Micrometrics Pycnometer-rel mérték meg.

Az elkészített oldatok viszkozitását Ostwald-féle viszkoziméter segítségével határoztam meg. Először a tisztított víznek a két jel közötti átfolyási idejét mértem meg, majd a többi oldatét ehhez viszonyítva, a sưrűség figyelembe vételével kaptam meg az oldatok relatív viszkozitását:

$$
\eta_{\mathrm{rel}}=\frac{\rho \cdot t}{\rho_{\mathrm{víz}} \cdot t_{\mathrm{víz}}}
$$

\subsection{Kiértékelési módszerek}

\subsubsection{Az áramlásvezérelt csapadékmintázatok esetén alkalmazott mód- szerek}

\section{A csapadékgyứrúk méretének meghatározása}

A kísérletekről azonos idő elteltével ( $\mathrm{t}=240 \mathrm{~s})$ készített képekről képpontegységben olvastam le a jellemzố alakzatok méretét (lásd a 4.2. ábrát). Kalibrációs képeket készítettem milliméterpapír segítségével az egyes kísérletek elôtt, és a képek feldolgozásakor kapott kalibrációs egyenes segítségével a kapott távolságokat hosszúságegységbe váltottam át. Adott gyưrúsugarak átlagát és szórását öt mérés adataiból állapítottam meg.

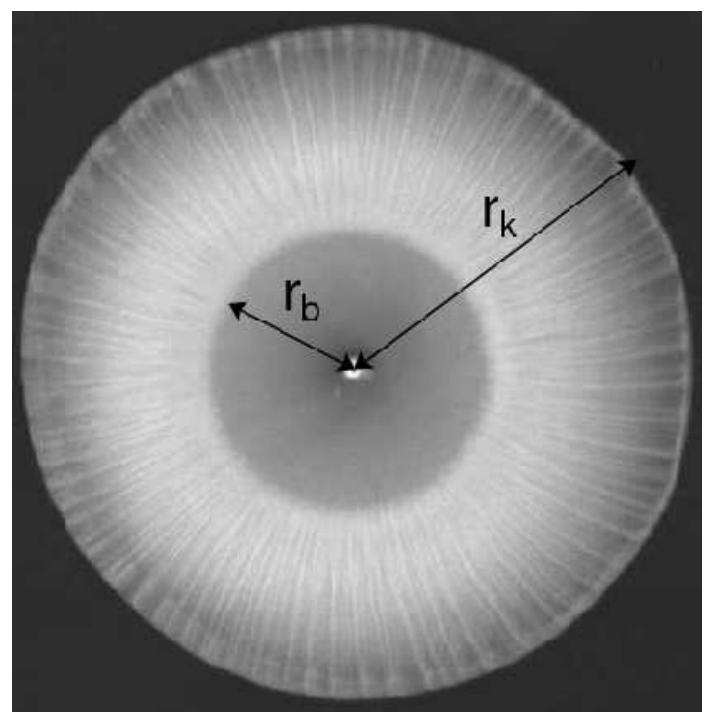

4.2. ábra. A belső $\left(r_{\mathrm{b}}\right)$ és a külső $\left(r_{\mathrm{k}}\right)$ kör sugara. A fehér rész a csapadéknak, míg a fekete a háttérnek felel meg. 


\section{A gravitációs áram átlagos magasságának meghatározása}

A gravitáció miatt nyomáskiegyenlítôdési folyamat indul el akkor, ha egy sưrú folyadékréteg véges, vízszintes tartományra terjed szét. A kiegyenlítődés erős áramlással jár a folyadék alján, ezért ezeket a mozgásokat gravitációs áramlatoknak nevezzük [118].

A csapadékképződés térbeli eloszlása követi a folyadék alján haladó sưrú réteget, ezért a szétterülő csapadékkorong felületéből egyben következtetni lehet a gravitációs áram átlagos magasságára $(\bar{h})$. A csapadékkorong felszínét $(A)$ az

$$
A=r^{2} \cdot \pi
$$

összefüggésból számíthatjuk, ahol $r$ a csapadékkör sugara, a beáramló oldat térfogatát $(V)$ pedig a

$$
V=q_{\mathrm{V}} \cdot t
$$

szorzat segítségével adhatjuk meg, ahol $q_{\mathrm{V}}$ a térfogat-áramlási sebesség, $t$ pedig az eltelt idő. Az előbbi két mennyiség hányadosából meghatározható a gravitációs áram átlagos magassága:

$$
\bar{h}=\frac{V}{A}=\frac{q \mathrm{~V} \cdot t}{r^{2} \cdot \pi}
$$

\section{A csapadék idốbeli változásának tanulmányozása}

A szabályos csapadékmintázatok területváltozásának meghatározásához házi készítésú program segítségével szürkeségi profilt készítettem a képfelvételekrôl. A szürkeségi skála a 0 értéktôl 255-ig terjed, ahol 0 a fekete színnek felel meg, a 255 pedig a fehérnek. Megadtam a középpont koordinátáit és a vizsgálni kívánt csapadékkör maximális sugarát képpontegységben. Ezek alapján a program elkészítette a szürkeségi profilt adott időközönként - például minden második, vagy ötödik stb. képenként - a megadott hosszúságú sugár mentén. Minden képről származó adat egy átlagérték (a program a teljes kör mentén átlagolta a megadott hosszúságú sugárról leolvasott adatokat). Így a 4.3. ábrán is bemutatott görbéket kaptam. Egy görbe egy idôponthoz tartozik. Elôször egy „,nagyon fehér” ( $\mathrm{I}=80 \mathrm{r}=85$ px) részt láthatunk, ami a 4.2. ábrán a külsố kör kezdetének felel meg. Tovább haladva a sugár mentén a nagyon éles intenzitáscsökkenés pedig a csapadékmintázat szélét, és a fekete háttér megjelenését mutatja. Azok inflexiós pontjaiból számítható a csapadék külsố és belsô körének sugara. Az előbbi a derivált görbék minimumaként, az utóbbi pedig a derivált görbék maximumaként definiálható. 


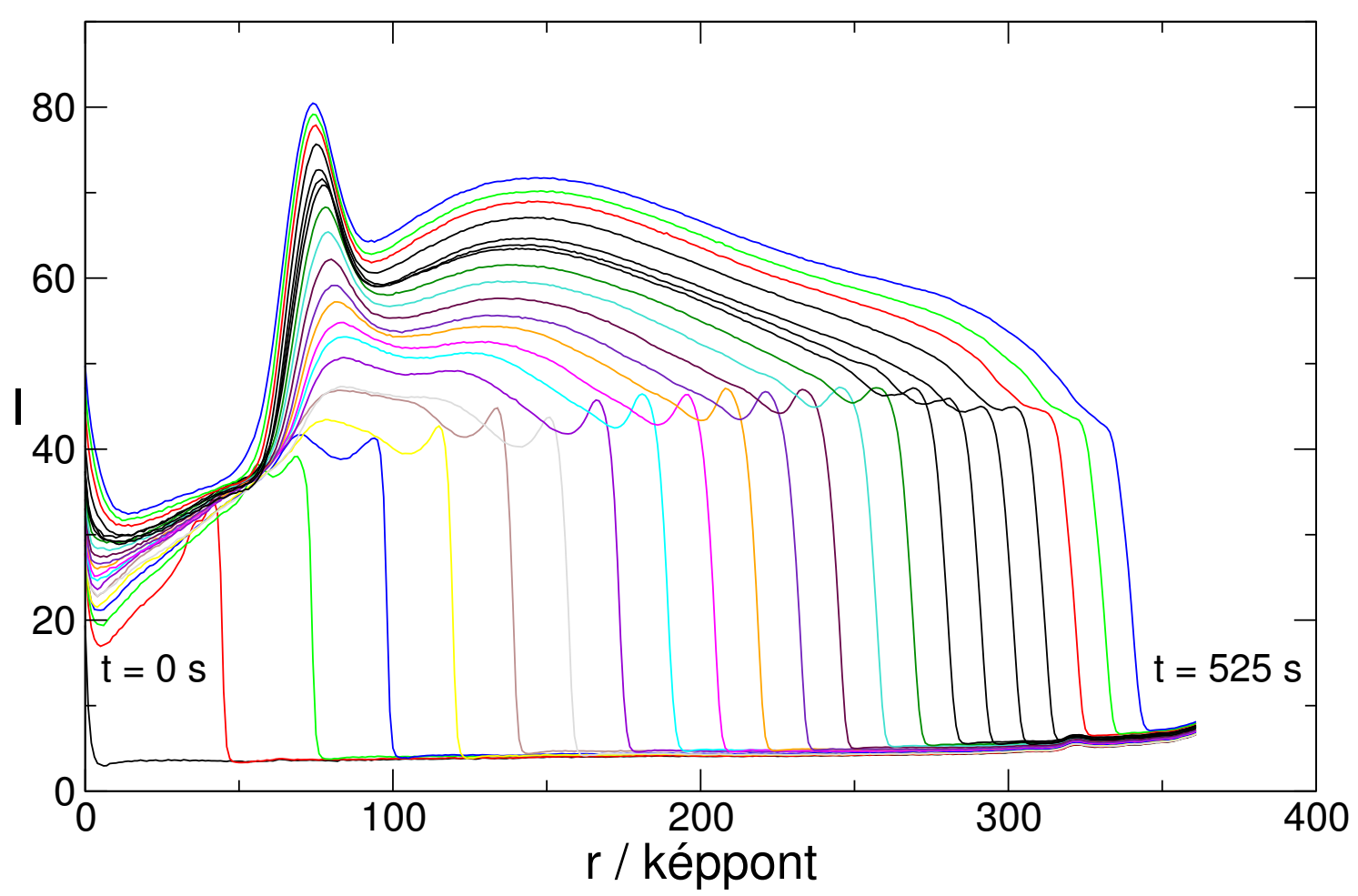

4.3. ábra. Szürkeségi skála intenzitás $(I)$ a távolság (sugár, $\left.r_{\mathrm{k}}\right)$ függvényében $(\Delta \mathrm{t}=25 \mathrm{~s})$.

Egy sưrú folyadékréteg kevésbé sûrű közeg alján sugárirányban történő szétterülése négyzetgyökös összefüggést mutat $(\mathrm{r} \sim \sqrt{t})$ a következő elgondolások alapján:

$$
\frac{d V}{d t}=q_{\mathrm{V}}
$$

A kísérleteink során állandó térfogat-áramlási sebességet biztosítottam a perisztaltikus pumpa segítségével, azaz a (4.5) egyenletben szereplő hányados értéke konstans, a kifejezés a következő módon átrendezhetô:

$$
V=q_{\mathrm{V}} \cdot t
$$

Behelyettesítve a (4.4) egyenletet a következő összefüggéshez jutunk:

$$
\bar{h} \cdot r^{2} \cdot \pi=q_{\mathrm{V}} \cdot t
$$

Amelyből a sugár kifejezhető:

$$
r=\sqrt{\frac{q_{\mathrm{V}}}{\pi \cdot \bar{h}}} \cdot \sqrt{t} .
$$




\section{A szálak számának meghatározása}

A szálak számának meghatározása érdekében egy adott kör mentén készítettem szürkeségi profilt. Az ívmérték függvényében ábrázoltam ezen szürkeségi skála értékeit (lásd a 4.4. ábrát). A diagram helyi maximumai a csapadék fehér szálainak felelnek meg, amelyek viszonylag jól elkülönülnek a sötétebb háttértől, így számuk és helyük könnyen leolvasható az ábráról. Minden körnegyedben összeszámoltam a szálak számát, majd a kapott értékeket átlagoltam.

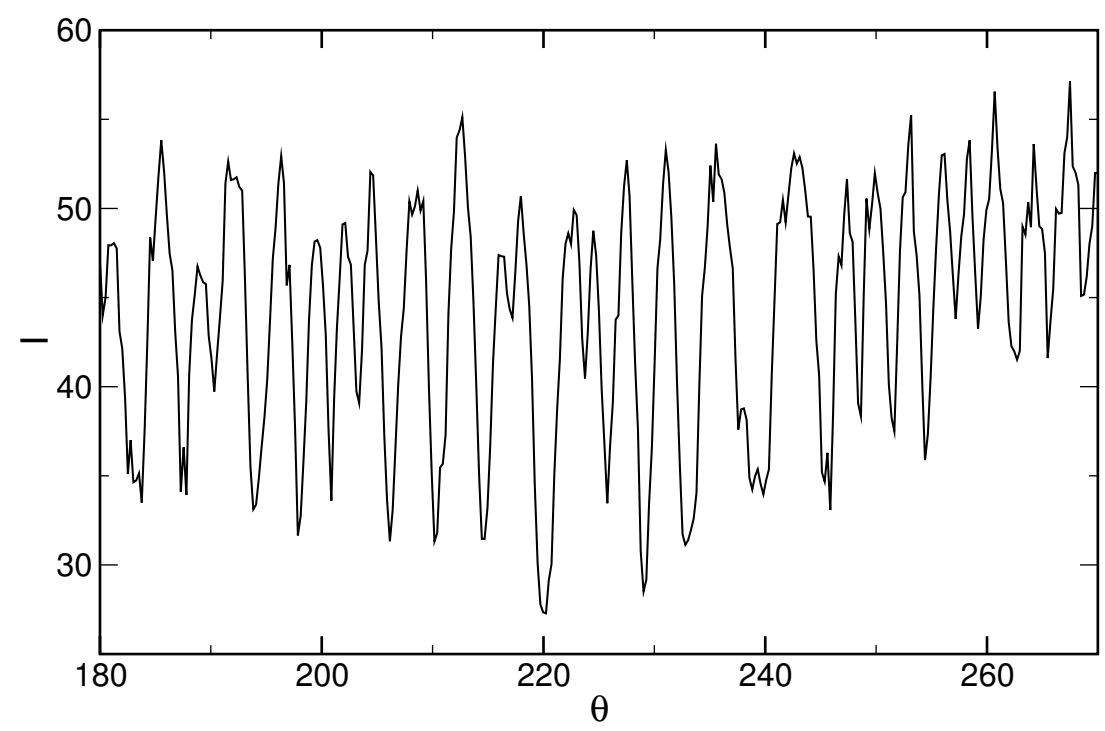

4.4. ábra. Szürkeségi skála intenzitás $(I)$ az ívmérték $(\theta)$ függvényében.

\section{Perisztaltikus pumpa kalibrálása}

A perisztaltikus pumpa kalibrálásakor ismert hőmérsékletú tisztított vizet áramoltattam át a folyadékot szállító csöveken. A pumpa skálarészét véletlenszerúen 10 és 90 között állítottam be különböző értékekre a szisztematikus hiba elkerülése végett. Mértem az átáramlott víz tömegét kiválasztott tömegegységenként, és ezzel párhuzamosan az eltelt idôt is. Az átáramlott víz tömegét az idő függvényében ábrázoltam, majd a kapott pontokra egyenest illesztettem. Az így kapott meredekséget, azaz a tömegáramlási sebességet, elosztottam a víz adott hőmérsékleten mért sưrüségével és meghatároztam a pumpára és a csövekre jellemző térfogat-áramlási sebességet. A kapott adatokat a pumpaskálarész függvényében ábrázolva, a pontokra a 4.5. ábra szerint illesztettem egyenest. A kapott egyenlet:

$$
y=(0,2667 \pm 0,0036) x,
$$

ahol $y$ a térfogat-áramlási sebesség, és $x$ a beállítható áramlási sebesség a pumpán, skálarészben kifejezve. Az egyenlet segítségével a kísérletek előtt könnyedén kiszámolható, hogy a kívánt térfogat-áramlási sebesség eléréséhez mekkora skálarészt kell beállítani a pumpán. 


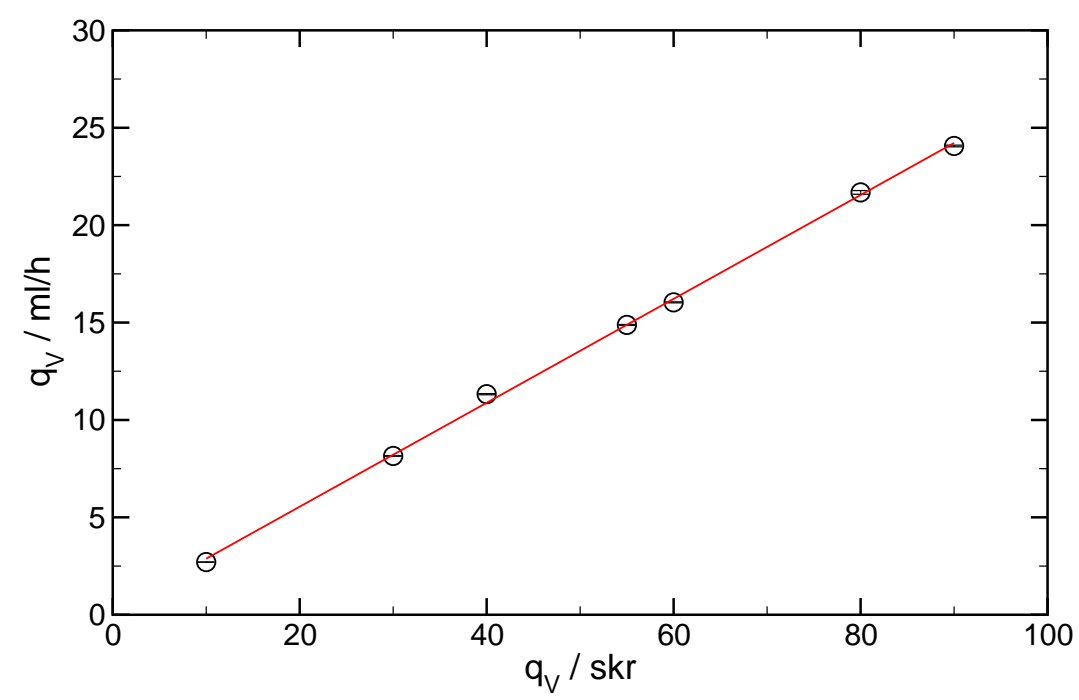

4.5. ábra. Térfogat-áramlási sebesség a pumpán beállítható skálarész függvényében.

\subsubsection{Az enzimreakciók során alkalmazott módszerek}

\section{Szürkeségi skála intenzitás meghatározása}

A kalcium-karbonát csapadékot tartalmazó jól kevert rendszerről két másodpercenként fotókat készítettem. Egy házi készítésú program egymás után megjelenítette az órareakciók illetve az oszcilláló reakció során felvett képeket, és a kijelölt területen belül meghatározta a szürkeségi skála értékét. Minden egyes képponthoz értéket rendelt, majd azt a teljes területen átlagolta. Ezt az átlagot ábrázolva az idő függvényében megkaptam a kívánt szürkeségi skála intenzitás-idő görbét.

\section{Az oszcilláció periódusidejének meghatározása}

Az enzimreakcióban bekövetkező oszcilláció periódusidejét a pH-görbe alapján számítottam. Fourier-transzformációt alkalmaztam, ezt követôen a kapott lokális maximumokat leolvastam, melyek közül az elsô megadja az oszcilláció karakterisztikus frekvenciáját.

\section{5. Ábrázolás}

A kiértékelés végeredményeként kapott ábrákat az xmgrace [119] programmal ábrázoltam, valamint a lineáris és nemlineáris illesztéseket is ezen program segítségével hajtottam végre. A fényképes ábrákat az xfig [120] programmal készítettem. 


\subsection{Egyensúlyi számítások}

Az egyensúlyi számítások egy részének célja az volt, hogy adott reaktánskoncentrációk mellett meghatározzam a csapadékok leválásának pontos pH-értékeit. Ezen számítások elvégzéséhez a Wolfram Mathematica [121] programot alkalmaztam. Megkerestem a csapadékok oldhatósági szorzatait, a komplexek stabilitási állandóit és a protonálódási állandókat. Egy új fájlba beírtam ezeket az értékeket és a hozzájuk tartozó egyensúlyokat, amint az a Függelék III.1. fejezetében olvasható. Majd felírtam a komponenesmérleg-egyenleteket az egyes komponensekre, például a kalciumionra, az oxalátionra és a karbonátionra.

Ezt követően a homogén rendszer összes egyensúlyára megoldottam az egyenletrendszert. A numerikus megoldások egyik - általam is használt - lehetősége a FindRoot parancs, mely tetszőleges egyenletre vagy egyenletrendszerre alkalmazható. Ezen belül meg kellett adnom a komponensek összmennyiségét, kiindulási értékeket, valamint azt a pH-tartományt, amelyen belül a számításokat végzi a program. A csapadékok leválását ekkor még csak a kö-

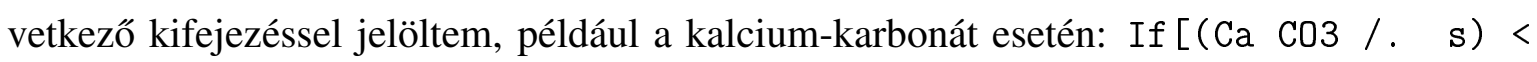
KspCaCO3, 0, 1]. Ez azt jelenti, hogy amint a kalciumionok és karbonátionok koncentrációjának szorzata eléri az oldhatósági szorzatot, akkor a kimeneti fájlban a 0 értéket felváltja az 1. A kimeneti fájl ezen sorától kezdve a számítások érvénytelenek.

Innentől a csapadék mennyiségét is figyelembe kell venni a mérlegegyenletek felírásakor, és az adott pH-értéktől új futtatást szükséges indítani. Ezt a számítást úgy érdemes elkezdeni, hogy az előző számítás végeredményeként kapott számadatokat adom meg kezdeti értékeknek, így a program könnyedén megtalálja a jó megoldást. Amennyiben ez sikertelen, akkor elképzelhetô hogy a bemeneti fájlt úgy kell átírni, hogy az adott komponens legnagyobb mennyiségben jelenlévő formájával fejezzük ki az egyenleteket, például karbonátion helyett hidrogén-karbonátionnal. Elképzelhető, hogy a számításaink csak akkor adnak megfelelôen pontos eredményt, ha $\mathrm{pH}=7$ felett a hidrogénion helyett hidroxidionnal fejezzük ki az egyenleteket. Abban az esetben, ha további csapadék leválása is szóba jöhet, akkor azt is a korábban említett feltételes kifejezéssel illetjük, és addig folytatjuk a számítást, amíg 0 helyett 1-re vált a kifejezés eredményeképpen kapott érték.

Ha a második csapadék is leválik, akkor a számítások egyszerúsítése végett újabb egyenleteket definiálva kiszámíthatóvá válik két komponens koncentrációja, például a kalciumion és a karbonátion (lásd a Függelék III.1. fejezetét). Így már nem egyenletrendszert kell megoldani, ami jelentôsen leegyszerúsíti a problémát. További csapadékok megjelenése esetén ugyanígy kell eljárni.

Amennyiben a pH-t szeretnénk meghatározni egy adott koncentrációtartományon, csapadék leválása közben, akkor a komponensmérleg-egyenletek mellett a töltésmérleg-egyenletre is szükségünk lehet. Ekkor a számítások nagyon hasonlítanak az előzőekben bemutatott számításokhoz, lásd a Függelék III.3. alfejezetét. 


\section{5. fejezet}

\section{Kalcium-oxalát csapadékmintázat}

\subsection{A koncentrációeloszlás számítása}

Egyensúlyi számításokkal határoztam meg a lehetséges komponensek egymáshoz viszonyított arányát, amihez az alábbi reakciókat vettem figyelembe [122].

A kalcium-oxalát csapadék leválása:

$$
\mathrm{Ca}(\mathrm{COO})_{2}(\mathrm{sz}) \rightleftharpoons \mathrm{Ca}^{2+}(\mathrm{aq})+(\mathrm{COO})_{2}^{2-}(\mathrm{aq}) \quad \mathrm{p} K_{\mathrm{SP}}=7,9
$$

A kalcium-hidroxid csapadék leválása:

$$
\mathrm{Ca}(\mathrm{OH})_{2}(\mathrm{sz}) \rightleftharpoons \mathrm{Ca}^{2+}(\mathrm{aq})+2 \mathrm{OH}^{-}(\mathrm{aq}) \quad \mathrm{p} K_{\mathrm{SP}}=5,1
$$

Különböző komplexképződési reakciók a kalciumionnal:

$$
\begin{aligned}
\mathrm{Ca}^{2+}(\mathrm{aq})+\mathrm{OH}^{-}(\mathrm{aq}) & \rightleftharpoons \mathrm{CaOH}^{+}(\mathrm{aq}) & & \lg \beta_{\mathrm{OH}}=1,15 \\
\mathrm{Ca}^{2+}(\mathrm{aq})+(\mathrm{COO})_{2}^{2-}(\mathrm{aq}) & \rightleftharpoons \mathrm{Ca}(\mathrm{COO})_{2}(\mathrm{aq}) & & \lg \beta_{1}=1,66 \\
\mathrm{Ca}(\mathrm{COO})_{2}(\mathrm{aq})+(\mathrm{COO})_{2}^{2-}(\mathrm{aq}) & \rightleftharpoons \mathrm{Ca}\left[(\mathrm{COO})_{2}\right]_{2}^{2-}(\mathrm{aq}) & & \lg \beta_{2}=2,69 \\
\mathrm{Ca}^{2+}(\mathrm{aq})+\mathrm{HOOC}-\mathrm{COO}^{-}(\mathrm{aq}) & \rightleftharpoons \mathrm{Ca}(\mathrm{HOOC}-\mathrm{COO})^{+}(\mathrm{aq}) & & \lg \beta_{\mathrm{H}_{1}}=1,38 \\
\mathrm{Ca}^{2+}(\mathrm{aq})+2 \mathrm{HOOC}-\mathrm{COO}^{-}(\mathrm{aq}) & \rightleftharpoons \mathrm{Ca}(\mathrm{HOOC}-\mathrm{COO})_{2}(\mathrm{aq}) & & \lg \beta_{\mathrm{H}_{2}}=1,80
\end{aligned}
$$

Az oxálsav protonálódási folyamatai:

$$
\begin{aligned}
\mathrm{H}^{+}(\mathrm{aq})+(\mathrm{COO})_{2}^{2-}(\mathrm{aq}) & \rightleftharpoons \mathrm{HOOC}-\mathrm{COO}^{-}(\mathrm{aq}) & & \lg K_{\mathrm{H}_{1}}=4,266 \\
\mathrm{H}^{+}(\mathrm{aq})+\mathrm{HOOC}-\mathrm{COO}^{-}(\mathrm{aq}) & \rightleftharpoons(\mathrm{COOH})_{2}(\mathrm{aq}) & & \lg K_{\mathrm{H}_{2}}=1,252
\end{aligned}
$$

A számításokat pH 1-14 tartományban, 1,0 és 4,0 mol · dm $\mathrm{dm}^{-3}$ össz kalciumion- és 0,1 és $0,025 \mathrm{~mol} \cdot \mathrm{dm}^{-3}$ össz oxalátion koncentrációkkal végeztem, 0,01 pH-egység lépésközönként, valamint $10^{-14}$ relatív hibát állítottam be a numerikus megoldáshoz. Ebben az esetben 
a homogén rendszerre végzett számításom azt mutatta, hogy már a legelső pontban leválik a csapadék, így a komponensmérleg-egyenletben rögtön számolnom kell a kalcium-oxalát szilárd anyag megjelenésével. A második futtatást a pH =11,12-14,00 tartományon végeztem a kalcium-hidroxid csapadékkal kiegészítve.

$A z$ 5.1. ábrán négy diagram, az $A$ és $B$ diagramon a kalciumiont tartalmazó, a $C$ és $D$ ábrán az oxalátion tartalmú részecskék eloszlása látható. Az A és B ábrán a szabad kalciumion van jelen nagy mennyiségben, mely érthetô hiszen nagy felesleget állítottam be. A tanulmányozott $\mathrm{pH}$-tartományban a kalcium-oxalát, erôsen lúgos tartományban $(\mathrm{pH}>11)$ pedig a kalcium-hidroxid szilárd fázis válik ki meghatározó mennyiségben. Ekkor a kalciumhidroxid komplex mennyisége is csökkenni kezd. A C és D ábrán jól látható, hogy a kalciumhidroxid csapadék megjelenésével az oxalátion felszabadul. A komplexek, valamint az oxálsav protonált formái nagyon kis mennyiségben vannak jelen a számítások szerint.
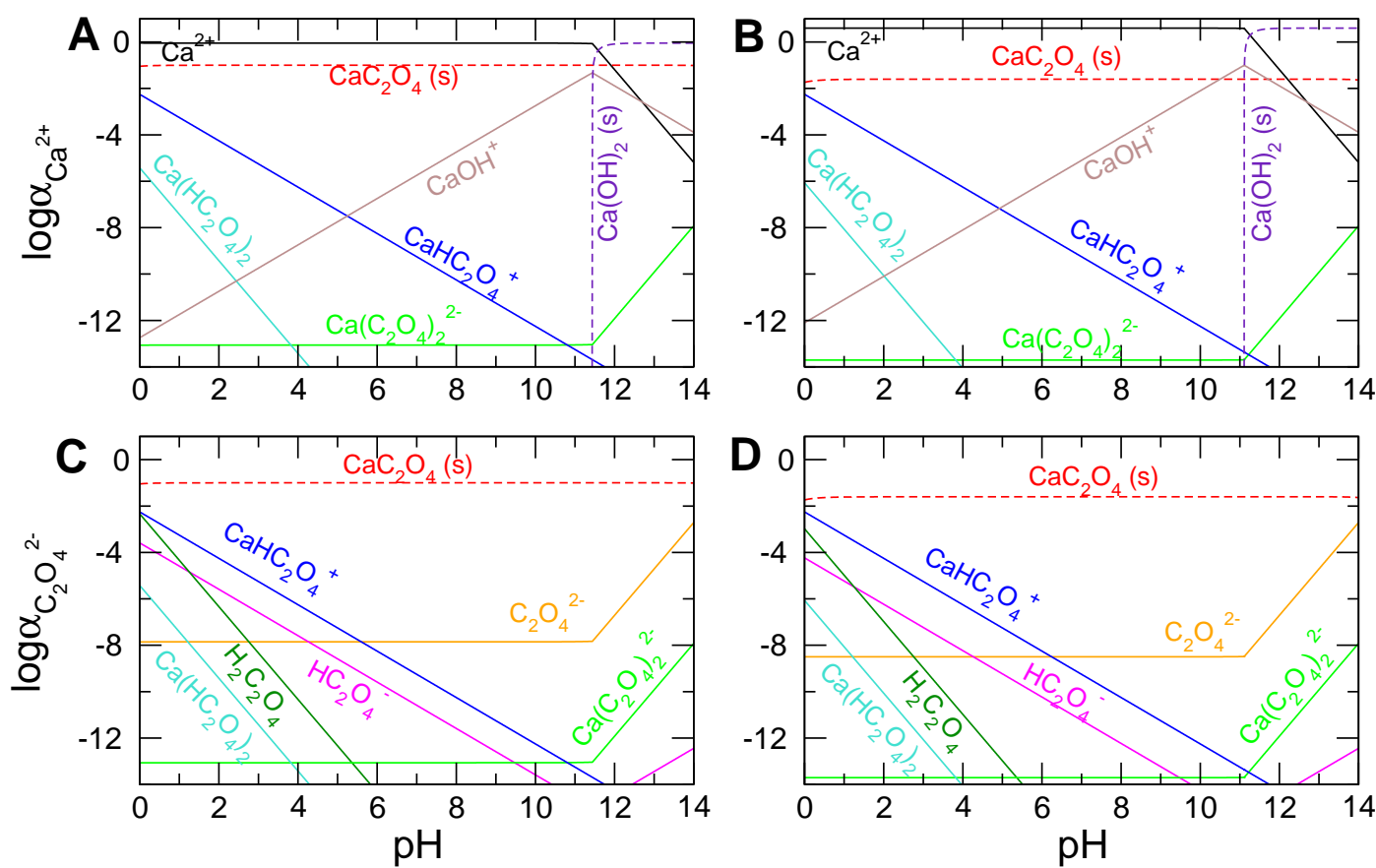

5.1. ábra. A komponensek aránya a $\mathrm{pH}$ függvényében $1,0 \mathrm{~mol} \cdot \mathrm{dm}^{-3}$ kalcium-klorid, $0,1 \mathrm{~mol} \cdot \mathrm{dm}^{-3}$ nátrium-oxalát (A) és (C); 4,0 $\mathrm{mol} \cdot \mathrm{dm}^{-3} \mathrm{kalcium}$-klorid, $0,025 \mathrm{~mol} \cdot \mathrm{dm}^{-3}$ nátrium-oxalát (B) és (D) koncentráció esetén. 


\subsection{A reaktánsok koncentrációjának változtatása}

Ha jól kevert rendszerben a nátrium-oxalát-oldatot a kalcium-klorid-oldattal elegyítettem, akkor - függetlenül attól, hogy kalciumion vagy oxalátion feleslegébe adagoltam a másik reaktánst - mindig fehér színú csapadék pillanatszerú megjelenését tapasztaltam.

Áramlásvezérelt körülmények között, a kalcium-klorid-oldat betáplálásának helye körül szintén fehér színú kalcium-oxalát-csapadék képződik, csapadékrészecskékkel szegényebben borított belső kör formájában. Körülötte szimmetrikusan helyezkedik el egy fehér gyûrú, amely a kutatócsoportban már vizsgált oxalátcsapadékokhoz hasonlóan, sugárirányban szálszerú képződményeket tartalmaz (5.2. ábra).

A pumpa leállítását követően az edényben lévő el nem reagált komponensek között is lejátszódott a reakció, így a csapadékkorong sugara tovább nő és új csapadékréteg válik le a meglévő mintázatra.

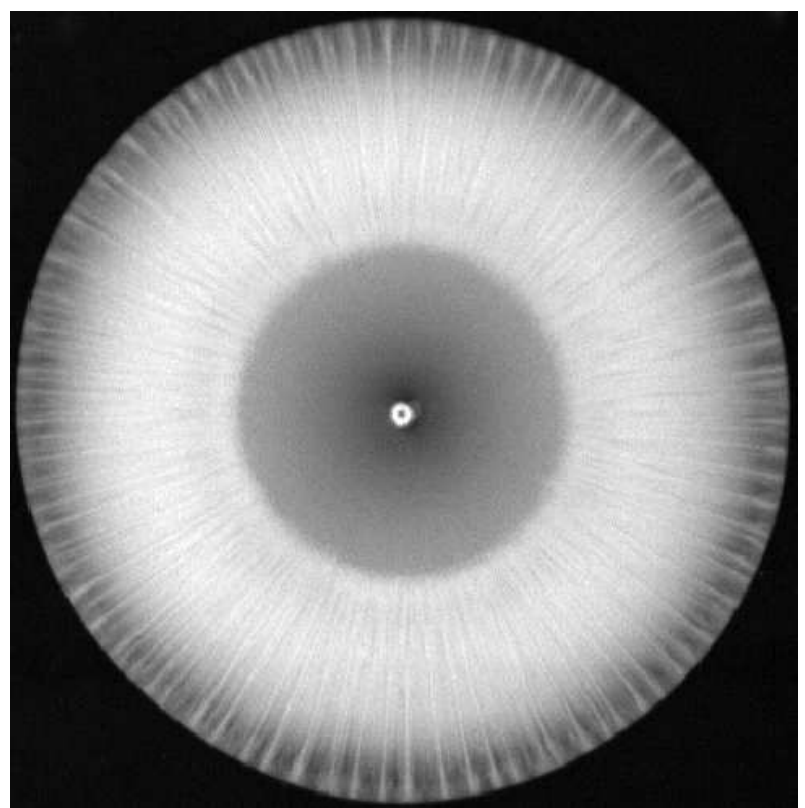

5.2. ábra. A kalcium-oxalát csapadék áramlásvezérelt körülmények között kialakult mintázata. Az ábra világos részei a kalcium-oxalát csapadékmintázatnak, míg a fekete szín a háttérnek felel meg 4 perc eltelte után.

Az áramlásvezérelt körülmények között kialakuló mintázat feltérképezésének elsô lépéseként a reaktánsoldatok kezdeti koncentrációit változtattam, miközben a nátrium-oxalátoldat kémhatását állandó értéken $(\mathrm{pH}=9,0)$ tartottam, a térfogat-áramlási sebességet pedig $20 \mathrm{~cm}^{3} \cdot \mathrm{h}^{-1}$-nak választottam.

Az 5.3. ábrán a csapadékokról a beáramoltatás kezdetétől számított negyedik percben készített fotók láthatóak. Megfigyelhetjük, hogy szimmetrikus geometria, azaz kör csupán néhány kísérleti összetételnél alakult ki. Ez annak köszönhetô, hogy a beáramló nagy sűrúségú folyadékréteg úgy mozgott az edényben, hogy a kisebb sûrúségû oldat alatt maradjon. Így 


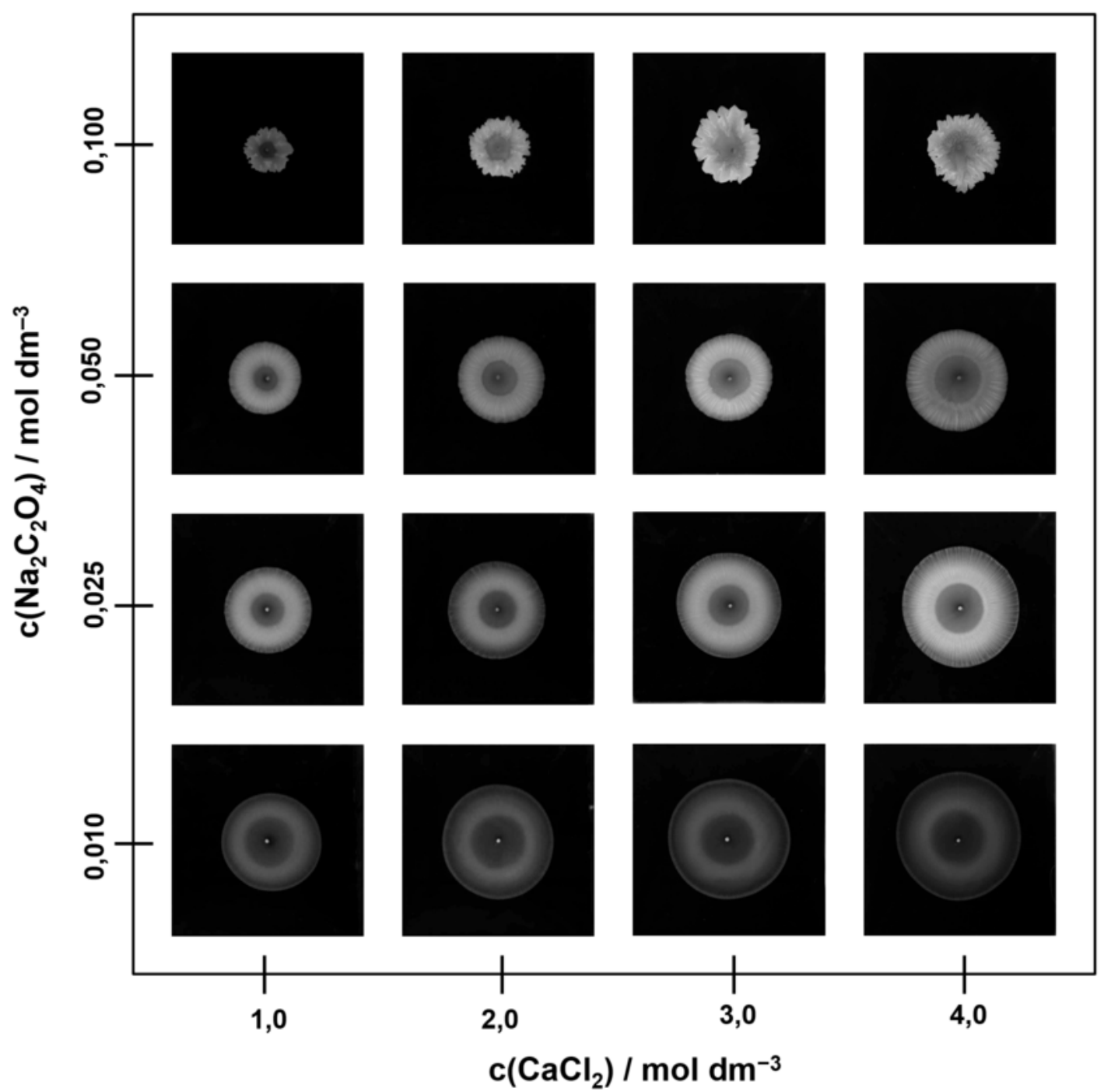

5.3. ábra. A kalcium-oxalát csapadékmintázat feltérképezése: a reagensek koncentrációinak változtatása $\left(t=240 \mathrm{~s}, q_{\mathrm{V}}=20 \mathrm{~cm}^{3} \cdot \mathrm{h}^{-1}\right.$ és $\left.\mathrm{pH}=9,0\right)$. A fényképeken látható terület: $24 \times 24 \mathrm{~cm}$.

ebben a vékony térrészben sugárirányba folyt, konvekciós gyưrük kialakulása mellett. Ezen gyưrû́k azt eredményezik, hogy a nagyobb sűrúségű folyadék bizonyos „vonalak” mentén feldúsul. Mivel esetünkben a csapadékképződés pillanatszerú, és tág koncentrációhatárok között végbemegy, azt feltételezzük, hogy minden idôpillanatban követni tudja a nagy súrúségú folyadék (esetünkben a kalcium-klorid-oldat) mozgását. A kísérlet elvégzése alatt szemtanúi lehettünk annak, ahogyan a csapadékképződési reakció mint egy indikátor, jelzi a folyadék mozgásának az útvonalát, és megőrzi azt a perisztaltikus pumpa kikapcsolása, azaz az áramlás megszúnése után is.

Hogy ezt megvizsgáljam, az 5.1. táblázatban az 5.3. ábrának megfelelő módon összegeztem az oldatok közötti sûrúségkülönbségeket, úgy, hogy pozitív értékhez jussak (azaz mindig a nagyobb sûrúségú kalcium-kloridból vontam ki a nátrium-oxalátnak az értékét). 
5.1. táblázat. A fázisdiagram pontjaihoz tartozó számított sűrűségkülönbség értékek, melyeket a $\Delta \rho=\rho\left(\mathrm{CaCl}_{2}\right)-\rho\left(\mathrm{Na}_{2} \mathrm{C}_{2} \mathrm{O}_{4}\right)$ egyenlet segítségével adtam meg $\mathrm{g} \cdot \mathrm{cm}^{-3}$ egységben.

\begin{tabular}{ccccc}
\hline \hline nátrium-oxalát & \multicolumn{4}{c}{ kalcium-klorid $\left(\mathrm{mol} \cdot \mathrm{dm}^{-3}\right)$} \\
$\left(\mathrm{mol} \cdot \mathrm{dm}^{-3}\right)$ & 1,0 & 2,0 & 3,0 & 4,0 \\
\hline 0,100 & 0,0780 & 0,1483 & 0,2064 & 0,3230 \\
0,050 & 0,0833 & 0,1536 & 0,2117 & 0,3283 \\
0,025 & 0,0860 & 0,1563 & 0,2144 & 0,3310 \\
0,010 & 0,0861 & 0,1564 & 0,2145 & 0,3311 \\
\hline \hline
\end{tabular}

Nagy oxalátkoncentrációk, azaz kis sưrúségkülönbségek esetében szabálytalan alakú csapadékokat kapunk. Ekkor a folyadék áramlása során szálak nem képződnek. Ha azonban jelentôs a sûrűségkülönbség a két reaktánsoldat között, akkor nagyobb sugarú és vékonyabb, szabályos és szálas csapadékréteg alakul ki.

A mintázatról a negyedik percben készített fénykép alapján meghatároztam a jellemző paramétereket (a belsô, és a külső kör sugara, szálak száma, gravitációs áram átlagos magassága). Az 5.2. táblázat soraiból kiolvasható, hogy a szálak számára sem hat kedvezően az oxalátion koncentrációjának a növelése. A gravitációs áram átlagos magassága adott térfogatáramlási sebesség mellett úgy nő, ahogy csapadék területe csökken (a (4.4) képlet alapján).

5.2. táblázat. A fázisdiagram pontjaihoz tartozó mintázatot leíró mennyiségek: a belső $\left(r_{\mathrm{b}}\right)$ és a külső $\left(r_{\mathrm{k}}\right)$ sugara, a szálak száma $(N)$, és a gravitációs áram átlagos magassága $(\bar{h})$.

\begin{tabular}{cccccc}
\hline \hline \multicolumn{2}{c}{ koncentrációk } & \multicolumn{4}{c}{ a mintázat jellemzó paraméterei } \\
$\begin{array}{c}\mathrm{CaCl}_{2} \\
\mathrm{Na}_{2} \mathrm{C}_{2} \mathrm{O}_{4}\end{array}$ & $r_{\mathrm{b}}$ & $r_{\mathrm{k}}$ & $N$ & $\bar{h}$ \\
$\left(\mathrm{~mol} \cdot \mathrm{dm}^{-3}\right)$ & $\left(\mathrm{mol} \cdot \mathrm{dm}^{-3}\right)$ & $(\mathrm{mm})$ & $(\mathrm{mm})$ & $(\mathrm{db})$ & $(\mathrm{mm})$ \\
\hline \multirow{3}{*}{1,0} & 0,010 & $29(0,5)$ & $59(1,0)$ & - & 0,12 \\
& 0,025 & $20(0,5)$ & $52(0,5)$ & - & 0,16 \\
& 0,050 & $14(0,5)$ & $44(0,5)$ & $76(4)$ & 0,22 \\
2,0 & 0,010 & $33(1,5)$ & $67(0,5)$ & - & 0,10 \\
& 0,025 & $24(0,5)$ & $59(0,5)$ & $112(4)$ & 0,12 \\
& 0,050 & $21(0,5)$ & $50(0,5)$ & $88(4)$ & 0,17 \\
3,0 & 0,010 & $30(0,5)$ & $72(0,5)$ & - & 0,08 \\
& 0,025 & $25(0,5)$ & $64(0,5)$ & $100(4)$ & 0,10 \\
& 0,050 & $24(1,0)$ & $53(1,0)$ & $76(4)$ & 0,15 \\
4,0 & 0,010 & $32(1,0)$ & $77(1,0)$ & - & 0,07 \\
& 0,025 & $29(0,5)$ & $69(0,5)$ & $156(8)$ & 0,09 \\
& 0,050 & $28(0,5)$ & $61(0,5)$ & $84(8)$ & 0,12 \\
\hline \hline
\end{tabular}




\subsubsection{A csapadékkorong területének változása az idôben}

Az 5.4. ábrán a csapadékok sugarának növekedését ábrázoltam. Mivel a mintázat két területe - a belső és a külsô kör is - jól elszeparálódik, házi készítésú programunk segítségével változásaikat külön-külön is nyomon tudjuk követni. A külső kör méretének változásait szemléltetố görbék alakja a négyzetgyökös összefüggéshez hasonlít. Amikor a kalciumklorid-oldat koncentrációját $1,0-4,0 \mathrm{~mol} \cdot \mathrm{dm}^{-3}$ között változtattam adott nátrium-oxalát koncentráció mellett, akkor az 5.4. ábra bal oldalán látható módon nőtt a belső és a külsô kör sugara is a beáramló oldat töménységével.

Amikor a nátrium-oxalát-oldat koncentrációját 0,01-rôl $0,1 \mathrm{~mol} \cdot \mathrm{dm}^{-3}$-re növeltem, akkor a legnagyobb értéknél még volt megfelelő sûrűségkülönbség a szabályos mintázat létrejöttéhez. Csökkenő nátrium-oxalát-koncentrációnál már meg tudtam vizsgálni az idôbeli változást, és azt tapasztaltam, hogy a belsô és a külső kör sugara is nô az 5.4. ábra jobb oldalán látható módon.
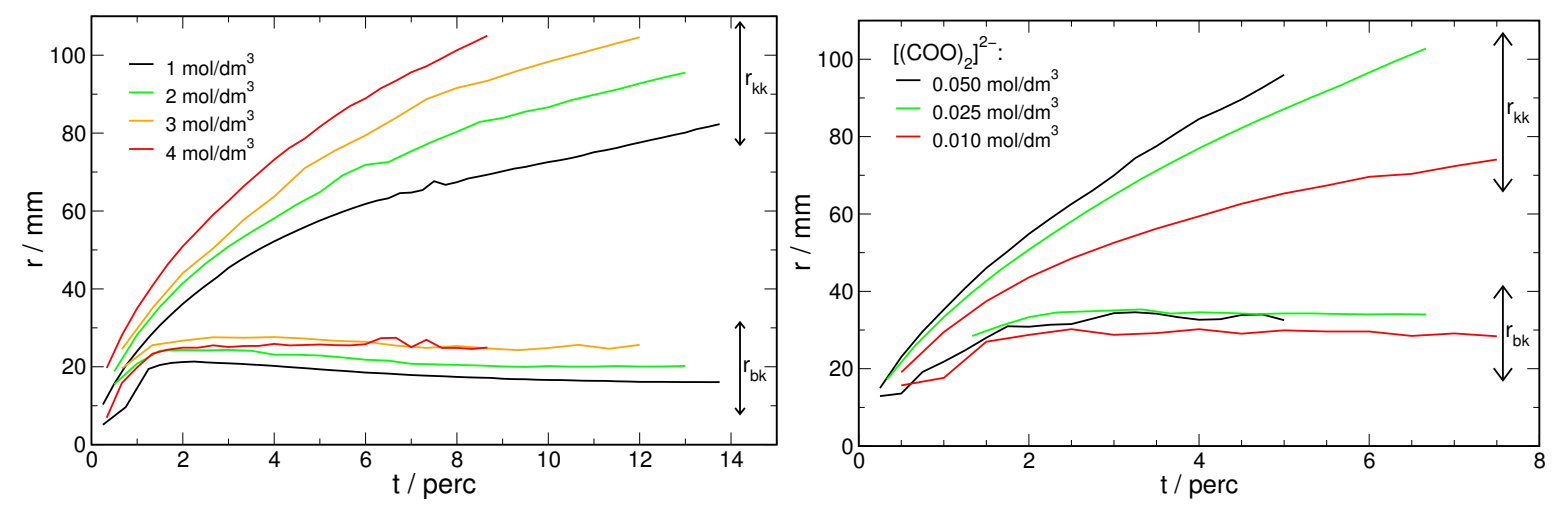

5.4. ábra. A csapadéksugarak változása $0,025 \mathrm{~mol} \cdot \mathrm{dm}^{-3}$ koncentrációjú nátrium-oxalát (bal) és 4,0 mol $\cdot \mathrm{dm}^{-3}$ kalcium-klorid-oldat (jobb) mellett ( $\mathrm{pH}=9,0$ és $\left.q_{\mathrm{V}}=20 \mathrm{~cm}^{3} \cdot \mathrm{h}^{-1}\right)$.

Minden kísérleti összetételnél hasonló lefutású görbéket kaptam. Az is látható, hogy a belső kör mérete a kezdeti periódus után állandó értékhez tart, míg a külső kör a levezetett (4.8) négyzetgyökös összefüggésnek megfelelően változik. A kísérleti adatokra egy háromparaméteres egyenletet illesztettem:

$$
y=a_{0} \cdot \sqrt{x+a_{1}}+a_{2} .
$$

Az illesztés paraméterei: $a_{0}=35,4 \pm 0,4 \mathrm{~cm} \cdot \mathrm{s}^{-1} ; a_{1}=-0,13 \pm 0,04 \mathrm{~s} ; a_{2}=2,8 \pm 1,1 \mathrm{~cm}$. Négyzetgyökös összefüggést abban az esetben kapnánk, ha a gravitációs áram magassága minden pontban egyenlő lenne. A kísérletek során azonban a betáplálás helyén a legmagasabb, a csapadék pereménél pedig a legalacsonyabb. Az $a_{0}$ érték a csapadékmintázat méretének növekedését jellemzi. Az $a_{1}$ és $a_{2}$ értékek megfeleltethetőek a kamera és a pumpa indítása időbeli különbségének, valamint a kiértékelés pontatlanságának. A betáplálás helyének pontos meghatározása nem lehetséges, mert a program szürkeségi skála alapján különíti 
el a csapadékot a háttértől. Így a szilikonragasztóval lezárt intenzív fehér rész zavarja a kiértékelést. Ezáltal a betáplálás valódi és a program által meghatározott helye különbözhet.

Az 5.5. ábrán láthatjuk, hogy a négyzetgyökös függés igaznak bizonyul, ezáltal azt is igazoltam, hogy a csapadékképződés minden pillanatban követi a sugárirányban terjedô nagy sûrúségú folyadék útját. Ez pedig a folyamat kinetikájában rejlik, azaz a pillanatszerú csapadékképződésben.

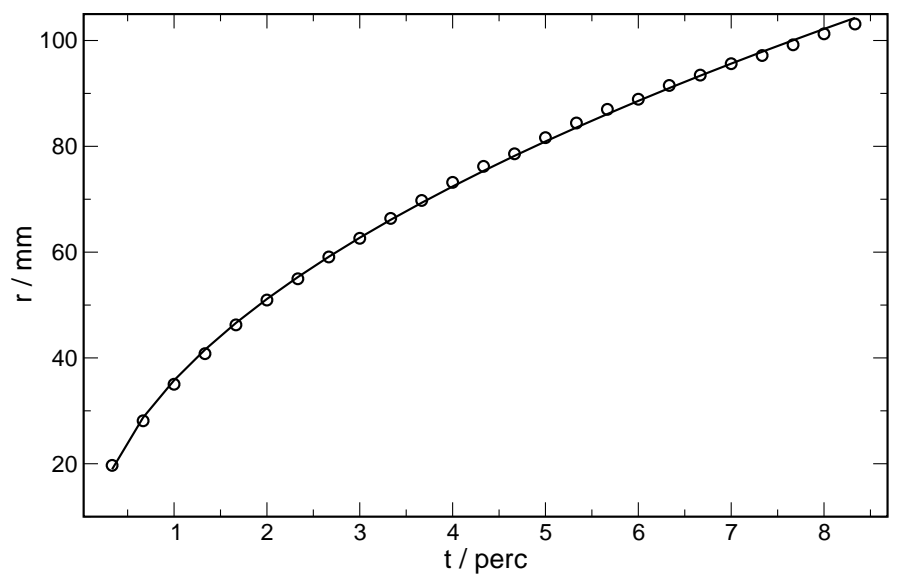

5.5. ábra. A kalcium-oxalát csapadékmintázat külsố sugarának növekedése. A pontok a kísérleti adatokat, míg a folytonos vonal az illesztett függvényt jelöli. A kísérleti paraméterek: $c\left(\mathrm{CaCl}_{2}\right)=4,0 \mathrm{~mol} \cdot \mathrm{dm}^{-3}, c\left(\mathrm{Na}_{2} \mathrm{C}_{2} \mathrm{O}_{4}\right)=0,025 \mathrm{~mol} \cdot \mathrm{dm}^{-3}, \mathrm{pH}=9,0$ és $q_{\mathrm{V}}=20 \mathrm{~cm}^{3} \cdot \mathrm{h}^{-1}$. 


\subsection{A nátrium-oxalát-oldat kémhatásának változtatása}

A következô kísérletsorozatban úgy állítottam elő a mintázatokat, hogy 4,0 $\mathrm{mol} \cdot \mathrm{dm}^{-3} \mathrm{kal}$ cium-klorid-oldatot áramoltattam $0,025 \mathrm{~mol} \cdot \mathrm{dm}^{-3}$ nátrium-oxalát-oldatba, melynek kémhatását pH-egységenként növeltem a 4,0 és 12,0 pH-tartományban. A kiértékelés során azt tapasztaltam, hogy a belsố és a külső kör sugarának nagysága hibán belül azonos a különböző pH-értékeken. Méretük növekedését az 5.6. ábrán, pontos értékeit az 5.3. táblázatban szemléltetem.

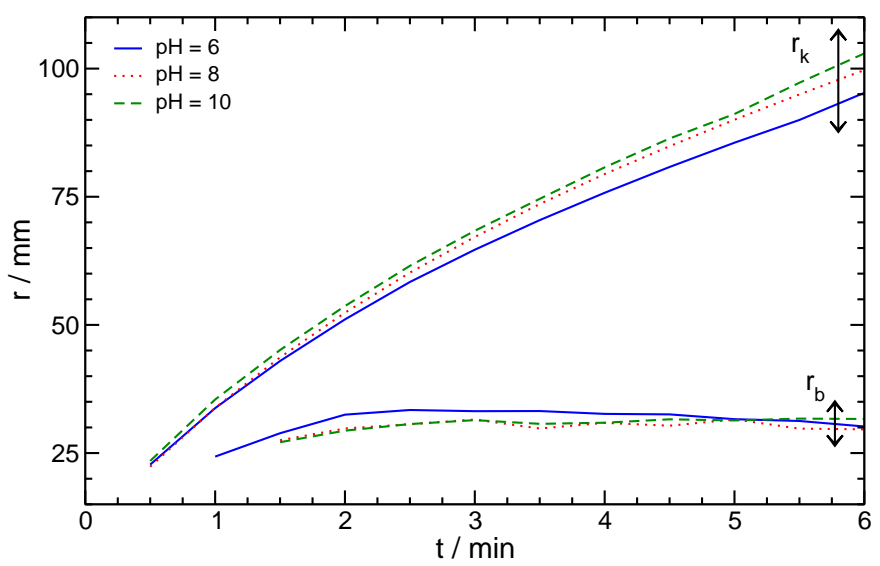

5.6. ábra. Különböző kémhatású nátrium-oxalát-oldatok hatása a belső és a külsô kör növekedésére $\left(c\left(\mathrm{CaCl}_{2}\right)=4,0 \mathrm{~mol} \cdot \mathrm{dm}^{-3}, c\left(\mathrm{Na}_{2} \mathrm{C}_{2} \mathrm{O}_{4}\right)=0,025 \mathrm{~mol} \cdot \mathrm{dm}^{-3}, q_{\mathrm{V}}=20 \mathrm{~cm}^{3} \cdot \mathrm{h}^{-1}\right)$.

Lúgosabb kémhatású oldatban nem végeztem kísérleteket, hogy elkerüljem a kalciumhidroxid csapadék kiválását. A szabályos kör alakú mintázatban $\mathrm{pH}=4,0$-nél sok szál található, de a csapadék átlátszóbb volta miatt nem jól láthatóak. A pH növelésének hatására, már pH = 5,0-nél jól észlelhetőek a mintázatban a szálszerú képződmények. A kísérletek lejátszódását követően az oldat kémhatása átlagosan két pH-egységgel csökkent ahhoz képest, amennyire a nátrium-oxalát-oldat kémhatását a kísérletet megelőzôen beállítottam, melynek magyarázatát az (5.1), az (5.8) és az (5.9) egyensúlyi folyamatok adják meg. 
5.3. táblázat. A nátrium-oxalát-oldat kémhatásának változtatása és a csapadékmintázat paraméterei $\left(c\left(\mathrm{CaCl}_{2}\right)=4,0 \mathrm{~mol} \cdot \mathrm{dm}^{-3}, c\left(\mathrm{Na}_{2} \mathrm{C}_{2} \mathrm{O}_{4}\right)=0,025 \mathrm{~mol} \cdot \mathrm{dm}^{-3}, q_{\mathrm{V}}=20 \mathrm{~cm}^{3} \cdot \mathrm{h}^{-1}\right)$

\begin{tabular}{ccccc}
\hline \hline $\mathrm{pH}$ & \multicolumn{4}{c}{ a mintázat jellemzó paraméterei } \\
- & $r_{\mathrm{k}}(\mathrm{cm})$ & $r_{\mathrm{b}}(\mathrm{mm})$ & $N(\mathrm{db})$ & $\bar{h}(\mathrm{~mm})$ \\
\hline 6,0 & $76(0,1)$ & $31(0,1)$ & $134,4(8)$ & 0,07 \\
7,0 & $74(0,1)$ & $31(0,1)$ & $136,7(8)$ & 0,08 \\
8,0 & $74(0,1)$ & $32(0,1)$ & $141,3(8)$ & 0,08 \\
9,0 & $70(0,0)$ & $29(0,1)$ & $156,0(8)$ & 0,09 \\
10,0 & $74(0,1)$ & $33(0,1)$ & $128,8(12)$ & 0,08 \\
11,0 & $74(0,2)$ & $33(0,1)$ & $145,6(16)$ & 0,08 \\
12,0 & $74(0,2)$ & $33(0,2)$ & $140,0(16)$ & 0,08 \\
\hline \hline
\end{tabular}

\subsection{A közegmozgás mintázatképződésre gyakorolt hatása}

\subsubsection{A kalcium-klorid-oldat térfogat-áramlási sebességének változta- tása}

A kísérleteket - melyek során a kalcium-klorid-oldat beáramoltatásának sebességét módosítottam - hat különböző $\left(2,5,10,15,20\right.$, illetve $\left.25 \mathrm{~cm}^{3} \cdot \mathrm{h}^{-1}\right)$ térfogat-áramlási sebességnél, állandó kalcium-klorid $\left(4,0 \mathrm{~mol} \cdot \mathrm{dm}^{-3}\right)$ és nátrium-oxalát koncentráció $\left(0,025 \mathrm{~mol} \cdot \mathrm{dm}^{-3}\right)$ mellett végeztem. Az 5.7. ábra szemlélteti az előállított mintázatokat a 4. percben.
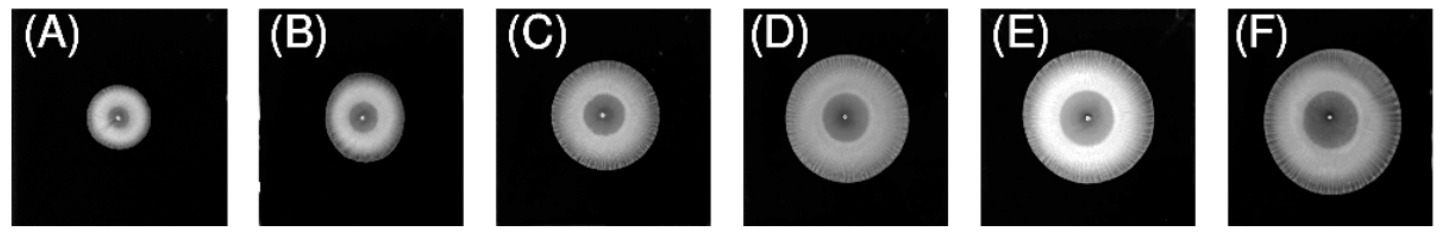

5.7. ábra. A mintázatok fényképe a negyedik percben különböző áramlási sebességeken: $2 \mathrm{~cm}^{3} \cdot \mathrm{h}^{-1}$ (A); $5 \mathrm{~cm}^{3} \cdot \mathrm{h}^{-1}$ (B); $10 \mathrm{~cm}^{3} \cdot \mathrm{h}^{-1}$ (C); $15 \mathrm{~cm}^{3} \cdot \mathrm{h}^{-1}$ (D); $20 \mathrm{~cm}^{3} \cdot \mathrm{h}^{-1}$ (E); és $25 \mathrm{~cm}^{3} \cdot \mathrm{h}^{-1}(\mathrm{~F})$. A képeken látható terület $23 \mathrm{~cm} \times 23 \mathrm{~cm}$. Az oldatösszetétel: $c\left(\mathrm{CaCl}_{2}\right)=$ $4,0 \mathrm{~mol} \cdot \mathrm{dm}^{-3}, c\left(\mathrm{Na}_{2} \mathrm{C}_{2} \mathrm{O}_{4}\right)=0,025 \mathrm{~mol} \cdot \mathrm{dm}^{-3}$, és $\mathrm{pH}=9,0$.

Azt tapasztaltam, hogy ha növelem a kalcium-klorid-oldat beáramoltatásának a sebességét, akkor nagyobb mennyiségben válik le a csapadék, mivel egyre több reaktáns került az oldatba. A mintázatot tanulmányozva láthatjuk, hogy $10 \mathrm{~cm}^{3} \cdot \mathrm{h}^{-1}$ térfogat-áramlási sebességig (az 5.7. ábra A-C képein) a belső korong még szabálytalan alakú, de $15 \mathrm{~cm}^{3} \cdot \mathrm{h}^{-1}$ térfogat-áramlási sebességtôl kezdve a belsố korong is szabályos kör alakot vesz fel és állandósul a szálak száma. A csapadékok széle valamennyi esetben sûrûn csipkézett, de egyértelmú kapcsolatot a szálak száma és a peremen levő csipkézettség között nem állapítottam 
meg. Az 5.4. táblázatban összegeztem a belső $\left(r_{\mathrm{b}}\right)$ és külső kör $\left(r_{\mathrm{k}}\right)$ sugarait, továbbá a szálak számát $(N)$ és a gravitációs áram átlagos magasságát $(\bar{h})$. A gravitációs áram átlagos magassága a térfogat-áramlási sebesség növelésével párhuzamosan nôtt. Megvizsgáltam a gyưrúk méretének növekedését is az idő függvényében, ami szintén a négyzetgyökös összefüggést mutatta.

5.4. táblázat. A térfogat-áramlási sebesség növelésének hatása a csapadékmintázat paramétereire $\left(c\left(\mathrm{CaCl}_{2}\right)=4,0 \mathrm{~mol} \cdot \mathrm{dm}^{-3}, c\left(\mathrm{Na}_{2} \mathrm{C}_{2} \mathrm{O}_{4}\right)=0,025 \mathrm{~mol} \cdot \mathrm{dm}^{-3}, \mathrm{pH}=9,0\right)$.

\begin{tabular}{ccccc}
\hline \hline$q_{\mathrm{V}}$ & \multicolumn{4}{c}{ a mintázat jellemzó paraméterei } \\
$\mathrm{cm}^{3} \cdot \mathrm{h}^{-1}$ & $r_{\mathrm{b}}(\mathrm{mm})$ & $r_{\mathrm{k}}(\mathrm{mm})$ & $N(\mathrm{db})$ & $\bar{h}(\mathrm{~mm})$ \\
\hline 2 & $34(1)$ & $11(1)$ & $68(8)$ & 0,04 \\
5 & $46(1)$ & $16(1)$ & $84(8)$ & 0,05 \\
10 & $59(1)$ & $22(2)$ & $92(8)$ & 0,06 \\
15 & $64(1)$ & $26(1)$ & $120(8)$ & 0,08 \\
20 & $69(2)$ & $29(1)$ & $120(8)$ & 0,09 \\
25 & $76(2)$ & $32(1)$ & $128(16)$ & 0,10 \\
\hline \hline
\end{tabular}

A szálak kialakulásának jobb megértése érdekében közelebbrôl is követtem a csapadék peremének változását. Az 5.8. ábra képein jól látható, hogy kialakul egy csapadékfelhő az áramló folyadékban. A növekvő csapadékkorong peremének hullámszerú mintázatát felveszi a leváló kalcium-oxalát részecskék halmaza. Az ezt követően képződő szilárd részecskék pedig a már kialakult csapadékra ülepednek áramlásvezérelt körülmények között, azaz a csapadék képződése csak a széleken figyelhető meg.
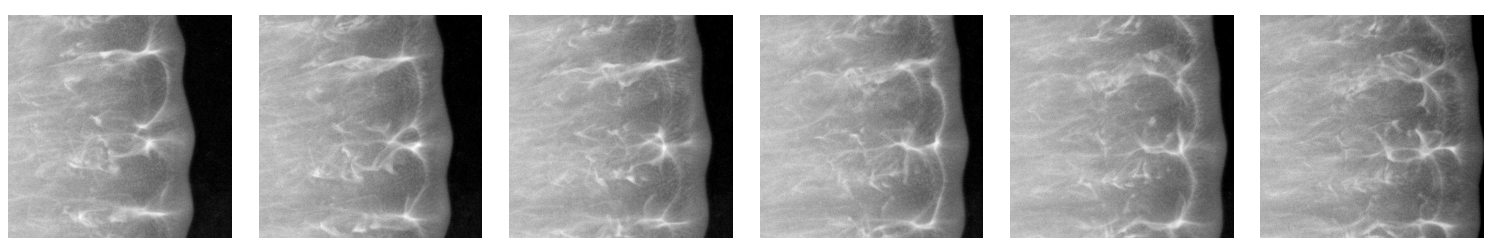

5.8. ábra. A csapadék peremének mozgása. A fényképeken látható terület $19 \mathrm{~mm} \times 19 \mathrm{~mm}$, a kísérleti paraméterek: $c\left(\mathrm{CaCl}_{2}\right)=4,0 \mathrm{~mol} \cdot \mathrm{dm}^{-3}, c\left(\mathrm{Na}_{2} \mathrm{C}_{2} \mathrm{O}_{4}\right)=0,025 \mathrm{~mol} \cdot \mathrm{dm}^{-3}$, $\mathrm{pH}=9,0$ és $q_{\mathrm{V}}=20 \mathrm{~cm}^{3} \cdot \mathrm{h}^{-1}$.

\subsubsection{A viszkozitás és a sû́rúség hatása a mintázatképző́désre}

A közegmozgás nem csak az áramlási sebesség növelésével változtatható, hanem a konvekciót befolyásoló sûrúségkülönbség és az oldatviszkozitás módosításával is. Referenciaként az $1 \mathrm{~mol} \cdot \mathrm{dm}^{-3}$ koncentrációjú kalcium-klorid-oldat sưrúségét és viszkozitását vettem alapul, és ebben az oldatban oldottam fel a sứrúséget és az oldatviszkozitást módosító anyagokat. 
Kísérleteimhez olyan anyagot kerestem, ami növeli a beáramló kalcium-klorid-oldat súrűségét, ezért nátrium-kloridot oldottam fel a kalcium-kloriddal együtt. A közös ion hatás miatt ezt csak akkor tehettem meg, ha az $1 \mathrm{~mol} \cdot \mathrm{dm}^{-3}$ kalcium-klorid mellett az oldat nátrium-kloridra nézve 1 , maximum $2 \mathrm{~mol} \cdot \mathrm{dm}^{-3}$ koncentrációjú volt. Azt tapasztaltam, hogy ez hatással van ugyan a mintázatképződésre, de a szálak kevésbé látszódnak, „,homályos" lesz a csapadék. Minél több nátrium-kloridot tartalmazott az oldat, annál nagyobb sugarú csapadékok alakultak ki. Továbbá az ionerôsséget is nagy mértékben megváltoztatja a hozzáadott só. Emiatt kerestem más, nem ionos, nagy sûrúségú vagy viszkózus anyagot. Választásom a glicerinre esett, ami a viszkozitást növeli, de nem lép reakcióba a csapadékképződési folyamat reagenseivel, így készítettem kalcium-kloridra nézve $1 \mathrm{~mol} \cdot \mathrm{dm}^{-3} \mathrm{kon}$ centrációjú, glicerinre nézve 1 és $2 \mathrm{~mol} \cdot \mathrm{dm}^{-3}$ töménységú oldatokat. Szintén azt tapasztaltam, amit a nátrium-kloridnál, hogy a csapadékok áttetszőek lettek. A glicerinre nézve töményebb oldat szétterülésének sebessége gyorsul az $1 \mathrm{~mol} \cdot \mathrm{dm}^{-3}$ koncentrációjú glicerines oldatéhoz képest, ráadásul több szál is található benne. A viszkozitás mellett az oldat sûrúsége is nagy mértékben változott, ezért kerestem másik anyagot, amelynél csak az egyik fizikai tulajdonság változik meg nagy mértékben.

A poli(vinil-alkohol)-t tartalmazó, $1 \mathrm{~mol} \cdot \mathrm{dm}^{-3}$ töménységú kalcium-klorid-oldattal elvégzett kísérlet szintén azt mutatta, hogy ugyan a viszkozitás nőtt, de a sưrûségkülönbség még mindig túl kicsi.

Poliakrilamiddal is végeztem kísérleteket, amelynek előnye, hogy a készített oldat sûrûsége nem változott jelentősen, viszont az oldat viszkozitása nagyon nagy mértékben megnőtt az adagolás hatására. Ekkor $1 \mathrm{~mol} \cdot \mathrm{dm}^{-3}$ koncentrációjú, $25 \mathrm{~cm}^{3}$ térfogatú kalciumkloridban 5, 10, $15 \mathrm{~g}$ viszkózus $0,5 \mathrm{~g} \cdot \mathrm{cm}^{-3}$ töménységú poliakrilamid-oldatot oldottam fel. Ebben az esetben a nátrium-oxalát koncentrációját 0,01 és $0,025 \mathrm{~mol} \cdot \mathrm{dm}^{-3}$-nek választottam. Az 5.9. ábrán olyan kísérleteket ábrázoltam, amelyeket a $0,025 \mathrm{~mol} \cdot \mathrm{dm}^{-3}$ nátriumoxalát koncentráció mellett végeztem el. Azoknál a kísérleteknél, ahol 5 g poliakrilamid-
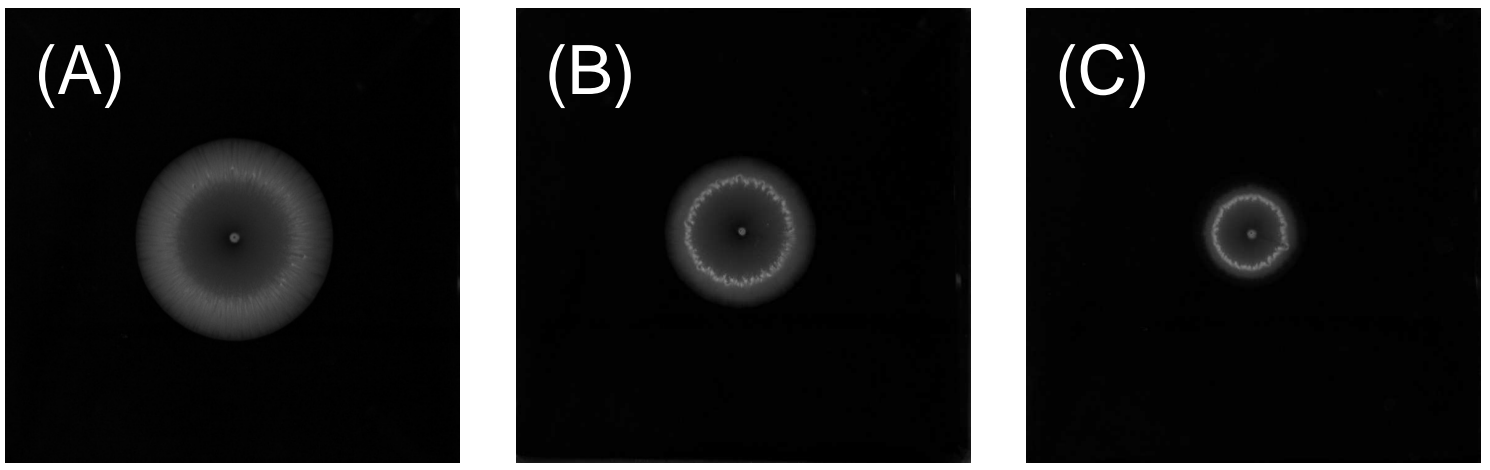

5.9. ábra. A nátrium-oxalát-oldatban oldott $0,1 \mathrm{~g} \cdot \mathrm{cm}^{-3}(\mathrm{~A}), 0,2 \mathrm{~g} \cdot \mathrm{cm}^{-3}(\mathrm{~B})$ és $0,3 \mathrm{~g} \cdot \mathrm{cm}^{-3}$ (C) poliakrilamid hatása a mintázatra. A fényképeken látható terület $24 \mathrm{~cm} \times 24 \mathrm{~cm}$, a kísérleti paraméterek: $c\left(\mathrm{CaCl}_{2}\right)=1,0 \mathrm{~mol} \cdot \mathrm{dm}^{-3}, c\left(\mathrm{Na}_{2} \mathrm{C}_{2} \mathrm{O}_{4}\right)=0,025 \mathrm{~mol} \cdot \mathrm{dm}^{-3}, \mathrm{pH}=9,0$, és $q_{\mathrm{V}}=20 \mathrm{~cm}^{3} \cdot \mathrm{h}^{-1}$. 
oldatot adtam hozzá, még nem tapasztaltam szabálytalan alakváltozást, csak a belső kör körül kis szálak alakultak ki (5.9. A ábra). Kétszeresére növelve a hozzáadott poliakrilamid mennyiségét, a belsô kör az 5.9. B. ábrán látható módon változott meg, vagyis szabálytalanná vált. A poliakrilamidra nézve legtöményebb oldattal már a külső kör sem vett fel szabályos alakot (5.9. C ábra).

Az 5.5. táblázatban összegeztem a különböző keverék oldatok sưrűségét és viszkozitását, a sugarak és a szálak számát, $0,025 \mathrm{~mol} \cdot \mathrm{dm}^{-3}$ nátrium-oxalát és az $1,0 \mathrm{~mol} \cdot \mathrm{dm}^{-3} \mathrm{kalcium}$ klorid mellett feloldott anyagokkal készült kísérleteket.

5.5. táblázat. Különböző adalékanyagokat tartalmazó $1,0 \mathrm{~mol} \cdot \mathrm{dm}^{-3}$ koncentrációjú kalcium-klorid-oldatok sûrúsége $(\rho)$ és viszkozitása $\left(\eta_{\text {rel }}\right)$, valamint ezen oldatok felhasználása során kialakult csapadékmintázatok jellemzô paraméterei. Referencia: $1,0 \mathrm{~mol} \cdot \mathrm{dm}^{-3}$ kalcium-klorid-oldat és $0,025 \mathrm{~mol} \cdot \mathrm{dm}^{-3}$ nátrium-oxalát-oldat reakciója.

\begin{tabular}{|c|c|c|c|c|c|c|c|}
\hline \multicolumn{2}{|c|}{ hozzáadott anyag } & \multicolumn{2}{|c|}{ többkomponensú oldat } & \multicolumn{4}{|c|}{ csapadékmintázat paraméterei } \\
\hline vegyület & koncentráció & $\begin{array}{c}\rho \\
\left(\mathrm{g} \cdot \mathrm{cm}^{-3}\right)\end{array}$ & $\eta_{\text {rel }}$ & $\begin{array}{c}r_{\mathrm{b}} \\
(\mathrm{mm})\end{array}$ & $\begin{array}{c}r_{\mathrm{k}} \\
(\mathrm{mm})\end{array}$ & $\begin{array}{c}N \\
(\mathrm{db})\end{array}$ & $\begin{array}{c}\bar{h} \\
(\mathrm{~mm})\end{array}$ \\
\hline ref. & $1,0 \mathrm{~mol} \cdot \mathrm{dm}^{-3}$ & 1,0859 & 1,27 & $20(1)$ & $52(1)$ & - & 0,16 \\
\hline \multirow{3}{*}{$\mathrm{NaCl}$} & $0,50 \mathrm{~mol} \cdot \mathrm{dm}^{-3}$ & 1,1135 & 1,36 & $21(1)$ & $54(1)$ & $120(4)$ & 0,15 \\
\hline & $1,00 \mathrm{~mol} \cdot \mathrm{dm}^{-3}$ & 1,1214 & 1,42 & $21(1)$ & $60(1)$ & $104(8)$ & 0,12 \\
\hline & $2,00 \mathrm{~mol} \cdot \mathrm{dm}^{-3}$ & 1,1569 & 1,73 & $22(1)$ & $67(1)$ & $92(8)$ & 0,10 \\
\hline \multirow{2}{*}{ glicerin } & $1,00 \mathrm{~mol} \cdot \mathrm{dm}^{-3}$ & 1,1063 & 1,80 & $22(1)$ & $53(1)$ & $144(4)$ & 0,15 \\
\hline & $2,00 \mathrm{~mol} \cdot \mathrm{dm}^{-3}$ & 1,1249 & 2,25 & $24(1)$ & $56(1)$ & $156(4)$ & 0,13 \\
\hline \multirow[t]{2}{*}{ PVA } & $0,05 \mathrm{~g} \cdot \mathrm{cm}^{-3}$ & 1,1177 & 7,25 & $25(1)$ & $49(1)$ & - & 0,17 \\
\hline & $0,10 \mathrm{~g} \cdot \mathrm{cm}^{-3}$ & 1,1744 & 4,97 & $27(1)$ & $49(1)$ & - & 0,18 \\
\hline \multirow[t]{2}{*}{ PAA } & $0,20 \mathrm{~g} \cdot \mathrm{cm}^{-3}$ & 1,1843 & 17,84 & - & $39(1)$ & - & 0,28 \\
\hline & $0,30 \mathrm{~g} \cdot \mathrm{cm}^{-3}$ & 1,2176 & 57,20 & - & - & - & - \\
\hline
\end{tabular}

Ha a kalcium-klorid-oldat viszkozitását növeltem valamilyen hozzáadott ionos, vagy töltéssel nem rendelkező anyag segítségével, akkor azt tapasztaltam, hogy a csapadék növekedése lelassul, mert a viszkozitás növelése a közegmozgás csökkentésével jár. A beáramló kalcium-klorid-oldat sû́rúségét növelve a csapadékmintázat területének növekedése felgyorsult a két oldat közti sûrûségkülönbség növekedése következtében. A nátrium-oxalát-oldat sûrûségét nem érdemes növelni, hiszen ha a sưrűsége nagyobb lenne, mint a kalcium-kloridoldaté, akkor a kalcium-klorid-oldat felfelé áramolna, és a csapadék nem az edény alján terülne szét szálas formában. 


\subsection{Termogravimetriás analízis}

Az irodalomból jól ismert tény, hogy a kalcium-oxalát több kristályvíztartalmú formában is létezik. Annak érdekében, hogy kiderítsük, az áramlásvezérelt körülmények között melyik módosulat van jelen, termogravimetriás méréseket hajtottunk végre. Azt egyértelmúen sikerült alátámasztani a lépcsôk számának és a százalékos tömegveszteségek figyelembe vételével, hogy a jól kevert és az áramlásvezérelt körülmények között is kalcium-oxalát csapadék képződik.

Az 5.10. ábrán együtt tüntettük fel a TG-, DTG-, és a DTA-görbéket, de az y-tengelyhez nem rendeltük hozzá a DTG-görbét. A TG-görbén három lépcső különül el, amelyek a következő folyamatokhoz rendelhetôk. A legalacsonyabb hőmérsékleten $\left(290{ }^{\circ} \mathrm{C}\right)$ először a kristályvíz távozik:

$$
\mathrm{Ca}(\mathrm{COO})_{2} \cdot 2 \mathrm{H}_{2} \mathrm{O}(\mathrm{sz}) \longrightarrow \mathrm{Ca}(\mathrm{COO})_{2}(\mathrm{sz})+2 \mathrm{H}_{2} \mathrm{O}(\mathrm{g}) \text {. }
$$

Majd $550{ }^{\circ} \mathrm{C}$-on karbonátosodás figyelhetô meg

$$
\mathrm{Ca}(\mathrm{COO})_{2}(\mathrm{sz}) \longrightarrow \mathrm{CaCO}_{3}(\mathrm{sz})+\mathrm{CO}(\mathrm{g}),
$$

míg a harmadik lépcsốben $900{ }^{\circ} \mathrm{C}$-on az oxidképződés következik be:

$$
\mathrm{CaCO}_{3}(\mathrm{sz}) \longrightarrow \mathrm{CaO}(\mathrm{sz})+\mathrm{CO}_{2}(\mathrm{~g})
$$

A kétféle oxalátcsapadék elméleti tömegveszteségeit az 5.6. táblázatban összegeztem. A számítások részletei a Függelék II. fejezetében találhatóak. A relatív tömegcsökkenést az egyes folyamatok előtti állapothoz viszonyítottam, hogy kiküszöböljem a kiindulási állapotban bizonytalanságot okozó zárványvíz hatását.

5.6. táblázat. A kalcium-oxalát csapadékok elméleti tömegveszteségei.

\begin{tabular}{rccc}
\hline \hline \multicolumn{4}{c}{ elméleti tömegveszteségek } \\
kiindulási anyag & $\Delta m_{290}{ }^{\circ} \mathrm{C}(\%)$ & $\Delta m_{550}{ }^{\circ} \mathrm{C}(\%)$ & $\Delta m_{900{ }^{\circ} \mathrm{C}}(\%)$ \\
\hline $\mathrm{Ca}(\mathrm{COO})_{2} \cdot 1 \mathrm{H}_{2} \mathrm{O}$ & 12,3 & 21,9 & 44,0 \\
$\mathrm{Ca}(\mathrm{COO})_{2} \cdot 2 \mathrm{H}_{2} \mathrm{O}$ & 21,9 & 21,9 & 44,0 \\
\hline \hline
\end{tabular}

Az 5.10. ábrán szereplő DTA-görbéken a vízvesztéshez tartozó endoterm, a karbonátosodáshoz tartozó exoterm, valamint az oxidképződéshez tartozó endoterm csúcs látható. A jól kevert rendszerben képződött minták esetén szintén a vízvesztéshez, az oxidképződéshez és a karbonátosodáshoz tartozó három lépcsôt láthatjuk a TG-görbén. A háromféle mintában mért százalékos tömegveszteségeket az 5.7. táblázatban összegeztem. A jól kevert minták tömegveszteségei gyakorlatilag megegyeznek az egy kristályvizet tartalmazó 
kalcium-oxalátéval. Az áramlás során kialakuló csapadékban nagyobb ugyan a víztartalom, ez azonban nem utal egyértelmúen a két kristályvizet tartalmazó kalcium-oxalát jelenlétére.

5.7. táblázat. A kalcium-oxalát csapadékok tömegveszteségei.

\begin{tabular}{lccc}
\hline \hline \multicolumn{4}{c}{ kísérleti tömegveszteségek } \\
\multicolumn{1}{c}{ minta } & $\Delta m_{290{ }^{\circ} \mathrm{C}}(\%)$ & $\Delta m_{550{ }^{\circ} \mathrm{C}}(\%)$ & $\Delta m_{900}{ }^{\circ} \mathrm{C}(\%)$ \\
\hline $\mathrm{CaC}_{2} \mathrm{O}_{4}$, jól kevert & 14,5 & 22,3 & 44,9 \\
$\mathrm{CaC}_{2} \mathrm{O}_{4}$, áramlásvezérelt külső kör & 14,7 & 19,5 & 41,8 \\
$\mathrm{CaC}_{2} \mathrm{O}_{4}$, áramlásvezérelt belső kör & 16,9 & 18,4 & 37,5 \\
$5 \mathrm{~m} / \mathrm{m} \% \mathrm{CaCl}_{2}, 95 \mathrm{~m} / \mathrm{m} \% \mathrm{CaC}_{2} \mathrm{O}_{4}$ & 16,3 & 21,3 & 42,2 \\
\hline \hline
\end{tabular}

Az áramlásvezérelt és a jól kevert kísérleti adatok eltérésének oka lehet a szárított mintában nyomnyi mennyiségben jelen lévő kalcium-klorid. Ez a nagy feleslegben beáramoltatott kalcium-klorid-oldat miatt maradhatott az oldatban, ezért felvettuik a két kristályvizet tartalmazó kalcium-klorid (5.10. B ábra), illetve az $5 \mathrm{~m} / \mathrm{m} \%$ kalcium-kloridot és $95 \mathrm{~m} / \mathrm{m} \%$ kalcium-oxalátot tartalmazó porminta TG-, DTG- és DTA-görbéjét is (5.10. C ábra). A diagramok alapján nem tudtuk kizárni a kalcium-klorid jelenlétét. Az 5.10. D ábrán együtt ábrázoltam a jól kevert, a belsô és a külső körből származó kalcium-oxalát, valamint a kalciumklorid TG-görbéjét.

Az áramlásvezérelt és a jól kevert minták közti eltérések további oka lehet, hogy nem tisztán az egy vagy a két kristályvizes kalcium-oxalátot szintetizálom, hanem vegyesen alakul ki a két anyag. Ennek bizonyítása érdekében azonban további szerkezetvizsgáló módszerek bevetése szükséges.

A kétféleképpen előállított csapadékot kiszárítottam, és a minták porsűrúségeit megmérettük, a jól kevert rendszerből származó mintának a sûrúsége volt a nagyobb, azaz 2,23 $\mathrm{g} \cdot \mathrm{cm}^{-3}$, az áramlásvezérelt mintáé $2,14 \mathrm{~g} \cdot \mathrm{cm}^{-3}$ volt. 

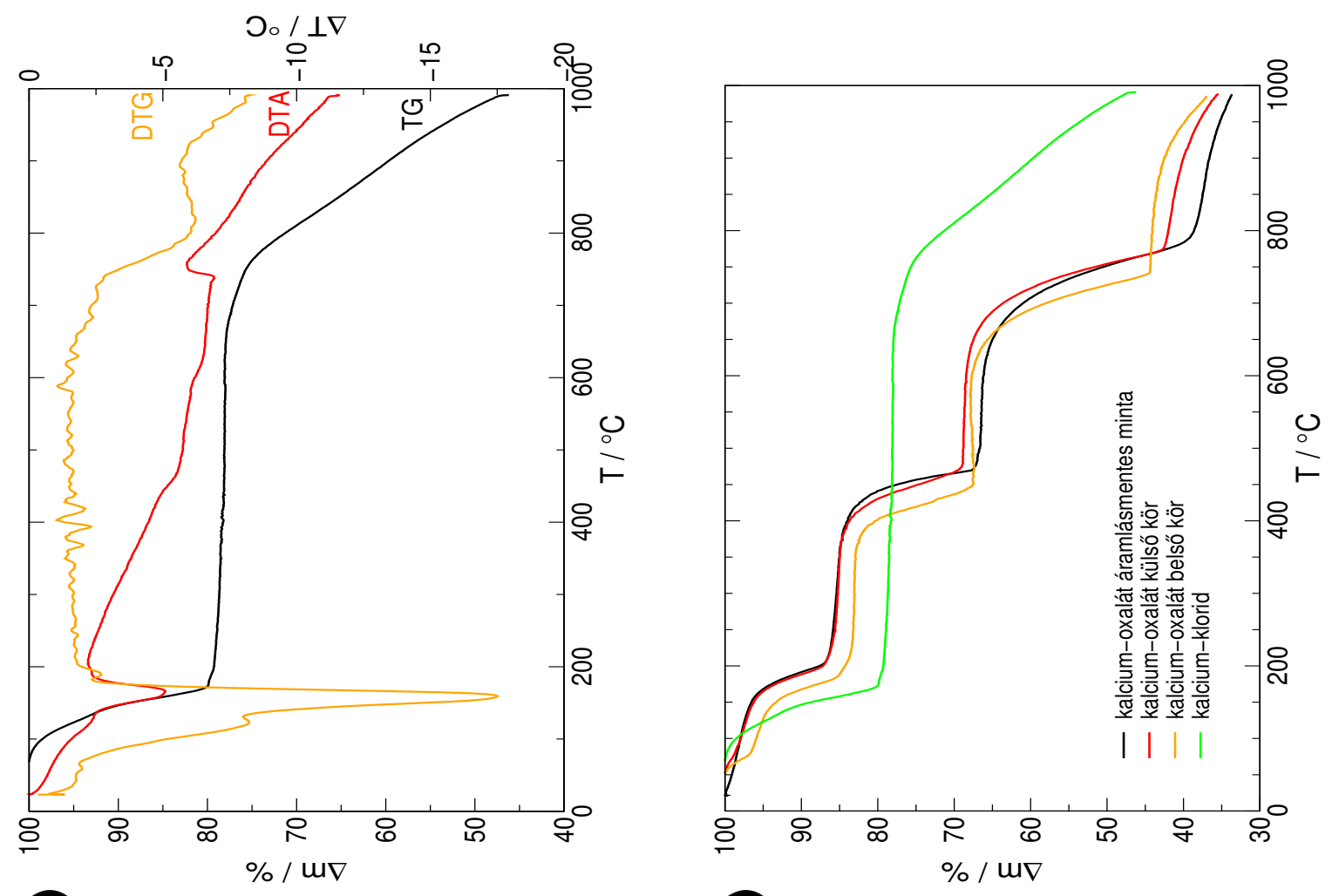

$\widehat{\underline{\underline{m}}}$
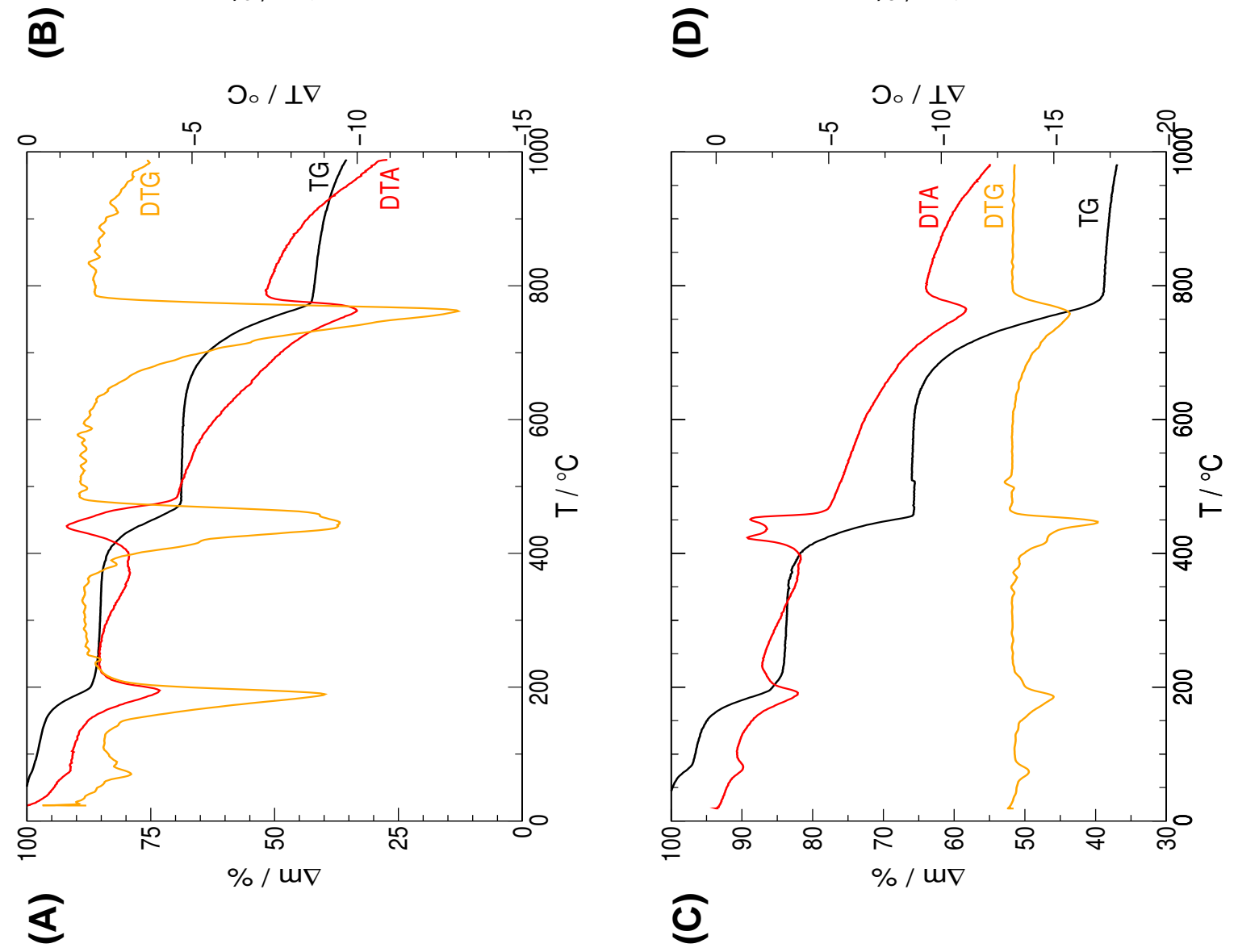

5.10. ábra. A külsô körből készített kalcium-oxalát porminta TG-, DTG-, DTA-görbéje (A). A két kristályvizet tartalmzó kalcium-klorid TG-, DTG-, DTA-görbéje (B). Az $5 \mathrm{~m} / \mathrm{m} \%$ kalcium-kloridot és $95 \mathrm{~m} / \mathrm{m} \%$ kalcium-oxalátot tartalmazó porminta TG-, DTG-, DTAgörbéje (C) a jól kevert, a belsô és a külsô körből származó kalcium-oxalát, valamint a kalcium-klorid TG-görbéje (D). 


\subsection{Infravörös spektroszkópiás vizsgálat}

Felvettük két különbözô térfogat-áramlási sebességú $\left(20 \mathrm{~cm}^{3} \cdot \mathrm{h}^{-1}\right.$ és $\left.100 \mathrm{~cm}^{3} \cdot \mathrm{h}^{-1}\right)$, valamint a jól kevert rendszerből származó mintának az infravörös spektrumát. Ugyanis a TG-görbék alapján nem dönthető el egyértelmúen, hogy mi okozza az áramlásvezérelt és jól kevert mintáink tömegveszteségei közötti eltéréseket: a kristályvíztartalom közötti különbség vagy a kalcium-klorid jelenléte. Felvettuik tehát a két kristályvizet tartalmazó kalciumklorid spektrumát is, amelyre a $400 \mathrm{~cm}^{-1}$-nél lévő szignifikáns elnyelés jellemző [123]. Az 5.11. ábrán a kalcium-klorid és a kalcium-oxalát spektrumának egy részlete található, ahol a kalcium-oxalát spektrumán $400 \mathrm{~cm}^{-1}$-nél nem jelenik meg intenzív elnyelés. Ezek a spektrumok alapján ugyan nem tudtuk meghatározni a csapadék kristályvíztartalmát, de azt igen, hogy a kiszáradt mintánkban nem kalcium-klorid okozza az eltérést.

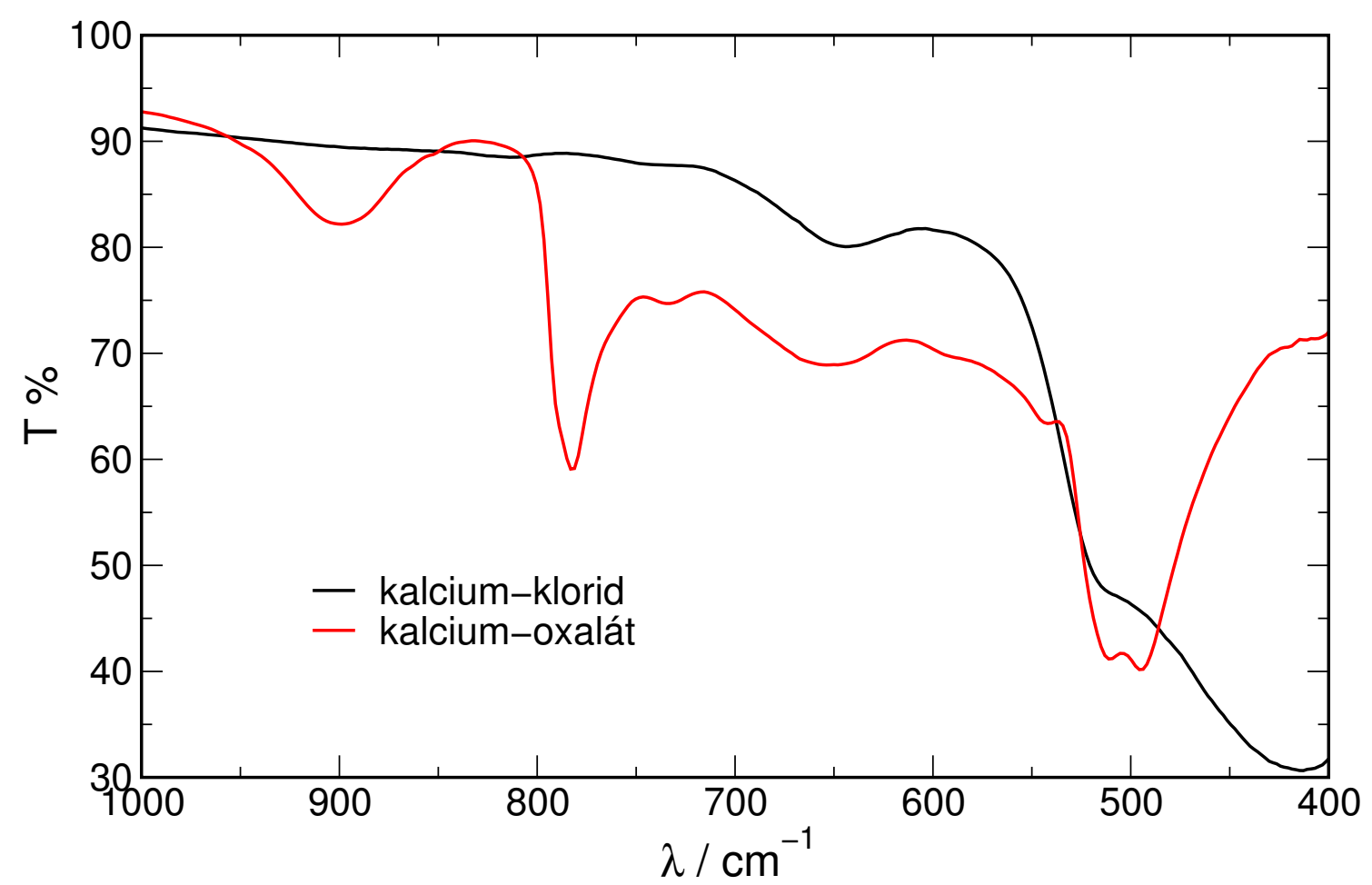

5.11. ábra. A $100 \mathrm{~cm}^{3} \cdot \mathrm{h}^{-1}$ térfogat-áramlási sebességgel kialakult kalcium-oxalát csapadék külső körének (piros), és a kalcium-klorid csapadék (fekete) infravörös színképe. A kísérleti paraméterek: $c\left(\mathrm{CaCl}_{2}\right)=4,0 \mathrm{~mol} \cdot \mathrm{dm}^{-3}, c\left(\mathrm{Na}_{2} \mathrm{C}_{2} \mathrm{O}_{4}\right)=0,025 \mathrm{~mol} \cdot \mathrm{dm}^{-3}$, és $\mathrm{pH}=9,0$. 


\subsection{Raman-spektroszkópiás vizsgálat}

A kalcium-oxalát különböző hidratált formái közül csak a monohidrát kristályok a termodinamikailag stabilak, így a reaktánsoldatok egyszerú összeöntésekor is ez a forma keletkezik [124]. Ha képződik is vizes oldatban a dihidrát forma, akkor sincs jelen hosszú ideig, gyorsan átalakul a stabilabb monohidrát formává. Ennek ellenére van lehetôség vizes közegben a kalcium-oxalát-dihidrát kristályok előállítására is, de ez nehézkes folyamat, mivel stabilizálása csak különböző hozzáadott szervetlen és szerves anyagok (foszfátok, szulfátok, citrát stb.) segítségével valósítható meg [125-127]. A kalcium-oxalát-dihidrát kristályok annak ellenére, hogy termodinamikailag nem stabilak, vesekövekben gyakran előfordulnak tiszta állapotban, azaz nem kristályosodnak együtt karbonátokkal, foszfátokkal, szemben a kalcium-oxalát-monohidráttal.

Az irodalomban ugyan találtam példát arra, hogy a tiszta monohidrát, dihidrát és trihidrát kristályokat termogravimetriás mérések segítségével megkülönböztették [124], de a legtöbb esetben, fôleg ha nem csak az egyik komponenst tartalmazza a minta, a termogravimetriás mérések nem szolgáltatnak megfelelő pontosságú eredményt. Leginkább Raman spektroszkópiás mérésekkel állapítható meg a pontos összetétel, mivel a színképeken az 1400-1500 $\mathrm{cm}^{-1}$ és a $900 \mathrm{~cm}^{-1}$ körüli tartományban lévő jellegzetes sávok alapján jól elkülöníthetőek a kalcium-oxalát különféle hidratált formái [98, 128].

A kalcium-oxalát-monohidrát spektrumában $1463 \mathrm{~cm}^{-1}$ és $1490 \mathrm{~cm}^{-1}$-nél jelenik meg két jellemző sáv, amelyek közül az elsőnek az intenzitása nagyobb. A kalcium-oxalátdihidrát spektrumában ugyanebben a tartományában csupán egyetlen intenzív sáv található $1477 \mathrm{~cm}^{-1}$-nél. A kalcium-oxalát-monohidrát spektrumában $896 \mathrm{~cm}^{-1}$-nél, míg a dihidrát spektrumában $911 \mathrm{~cm}^{-1}$-nél látható még egy-egy jellemző sáv.

Két különbözô térfogat-áramlási sebességú $\left(20 \mathrm{~cm}^{3} \cdot \mathrm{h}^{-1}\right.$ és $\left.100 \mathrm{~cm}^{3} \cdot \mathrm{h}^{-1}\right)$ és jól kevert rendszerből származó mintának vettük fel a Raman-spektrumát. A kiszárított mintázat belsô és a külső körében kialakult csapadékot összegyújtöttem majd homogenizáltam, hiszen a mintának csak egy kis mennyisége volt szükséges a mérés elvégzéséhez, így a reprodukálhatóság esélyét növeltem.

Igazoltuk a termogravimetriás mérés eredményét, azaz, hogy a jól kevert rendszerből származó minta kalcium-oxalát-monohidrátból áll. A $20 \mathrm{~cm}^{3} \cdot \mathrm{h}^{-1}$ térfogat-áramlási sebességú áramlásvezérelt körülmények között kialakult kalcium-oxalát csapadék külsố köre tartalmaz dihidrátot ugyan, de nagyrészt monohidrátból áll. A $100 \mathrm{~cm}^{3} \cdot \mathrm{h}^{-1}$ térfogatáramlási sebességú áramlásvezérelt rendszerben kialakult kalcium-oxalát csapadék belső köre kb. ugyanolyan mennyiségút tartalmaz mindkét formából. Nem mondható el ugyanez a külső körről, mert abban dominánsan a dihidrát forma van jelen (5.12. ábra). Tehát ez az áramlásvezérelt, egyensúlytól távoli rendszer a termodinamikailag nem stabil dihidrát forma képződésének kedvez (lásd a 5.8. táblázatot) [114]. A minta vizsgálatát egy héttel késôbb megismételve ugyanezt az eredményt kaptuk. 
5.8. táblázat. A kalcium-oxalát csapadékok Raman-spektrumában lévő jellemző sávmaximumok csökkenő intenzitásnak megfelelő sorrendben.

\begin{tabular}{cccccc}
\hline \hline \multicolumn{2}{c}{\begin{tabular}{c} 
referencia spektrumok $\left(\mathrm{cm}^{-1}\right)$ \\
\multicolumn{2}{c}{ kalcium-oxalát }
\end{tabular}} & \multicolumn{4}{c}{ a mért spektrumok eredményei $\left(\mathrm{cm}^{-1}\right)$} \\
monohidrát & dihidrát & - & külsố kör & $\begin{array}{c}100 \mathrm{~cm}^{3} \cdot \mathrm{h}^{-1} \\
\text { belsố kör }\end{array}$ & $\begin{array}{c}100 \mathrm{~cm}^{3} \cdot \mathrm{h}^{-1} \\
\text { külsố kör }\end{array}$ \\
\hline 1463 & 1477 & 1463 & 1463 & 1483 & 1483 \\
1490 & 911 & 1490 & 1487 & 1491 & 911 \\
896 & 1463 & 896 & 896 & 1461 & 1461 \\
\hline \hline
\end{tabular}
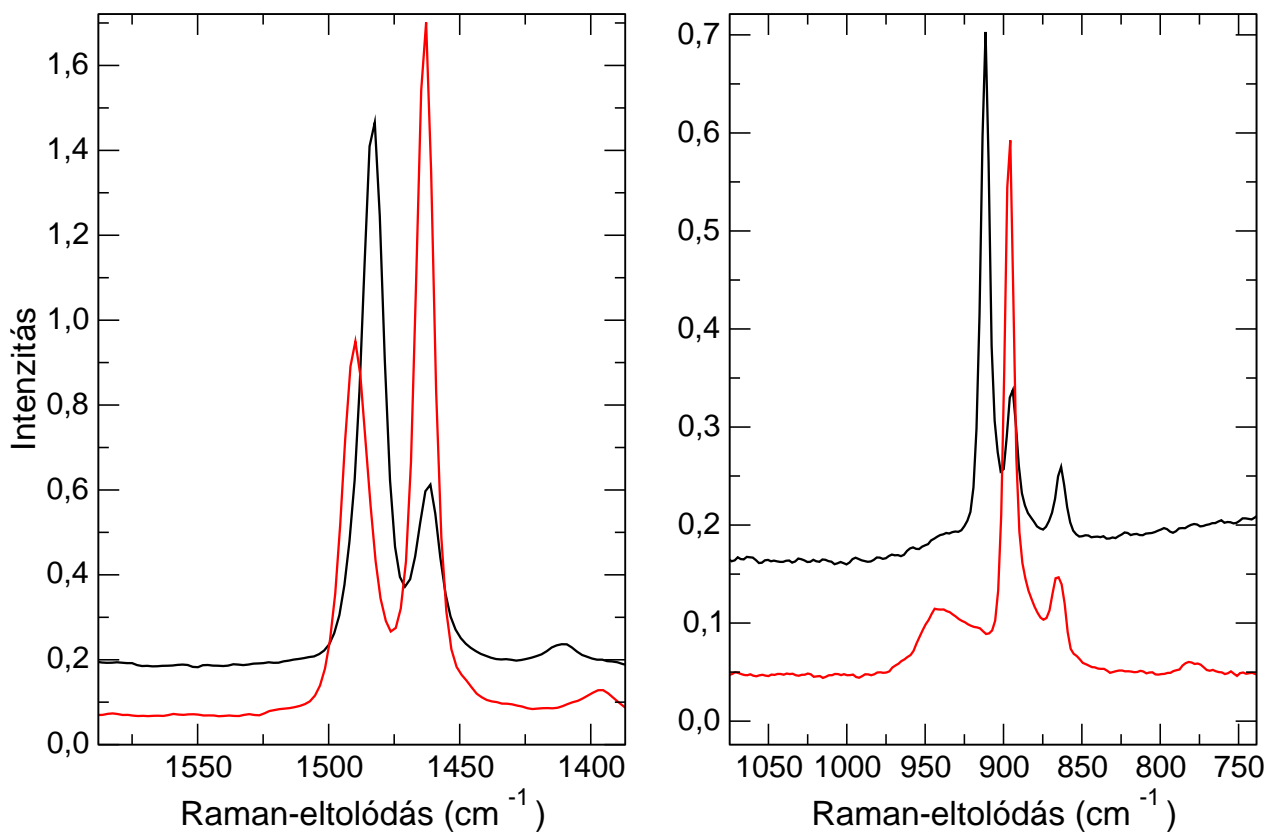

5.12. ábra. A $100 \mathrm{~cm}^{3} \cdot \mathrm{h}^{-1}$ térfogat-áramlási sebességgel kialakult kalcium-oxalát csapadék külső körének (fekete), és a $20 \mathrm{~cm}^{3} \cdot \mathrm{h}^{-1}$ térfogat-áramlási sebességgel kialakult kalciumoxalát csapadék belsố körének (piros) Raman-színképe. A kísérleti paraméterek: $c\left(\mathrm{CaCl}_{2}\right)=$ $4,0 \mathrm{~mol} \cdot \mathrm{dm}^{-3}, c\left(\mathrm{Na}_{2} \mathrm{C}_{2} \mathrm{O}_{4}\right)=0,025 \mathrm{~mol} \cdot \mathrm{dm}^{-3}$, és $\mathrm{pH}=9,0$.

Mivel a vesekövek esetében fontos paraméternek számít, hogy az anyagok együtt kristályosodnak-e vagy sem, úgy döntöttem, hogy megvizsgálom az egyedi részecskéket is. Ehhez a méréshez már Raman-mikroszkóp állt a rendelkezésemre. Megállapítottuk, hogy a két anyag elkülönülten kristályosodik, és meghatároztuk a különböző morfológiájú kalciumoxalát-monohidrát és a kalcium-oxalát-dihidrát részecskéket. A 5.13. ábra közepén piros + jellel a vizsgált részecskék vannak megjelölve. 

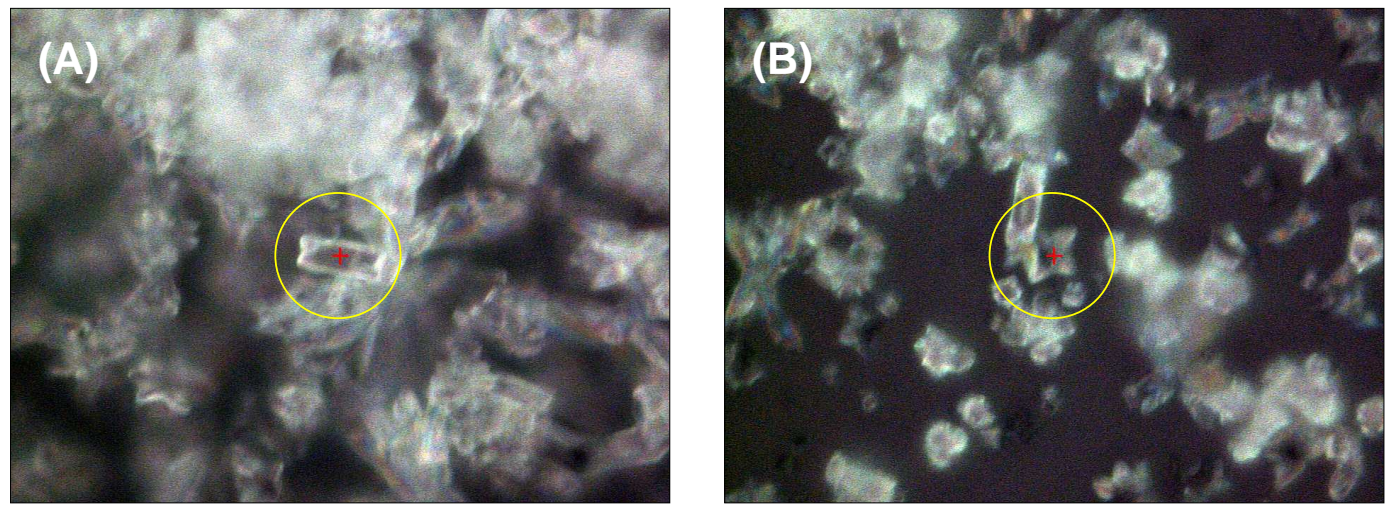

5.13. ábra. A kalcium-oxalát áramlásvezérelt körülmények között képződött részecskék Raman-mikroszkópiás felvétele. A piros + jellel megjelölt részecskéket vizsgáltuk. A kísérleti paraméterek: $c\left(\mathrm{CaCl}_{2}\right)=4,0 \mathrm{~mol} \cdot \mathrm{dm}^{-3}, c\left(\mathrm{Na}_{2} \mathrm{C}_{2} \mathrm{O}_{4}\right)=0,025 \mathrm{~mol} \cdot \mathrm{dm}^{-3}, \mathrm{pH}=9,0$, és $q_{\mathrm{V}}=20 \mathrm{~cm}^{3} \cdot \mathrm{h}^{-1}$.

Az 5.13. A ábrán lévő részecskéhez az 5.14. ábrán található fekete színú görbék tartoznak. A sávokra Gauss-Lorentz-görbéket illesztve megállapítottuk, hogy ez a morfológiájú kristály kalcium-oxalát-monohidrát. Az 5.13. B ábrán lévő részecske kalcium-oxalátdihidrátból áll, és a spektruma az 5.14. ábrán piros színnel látható.
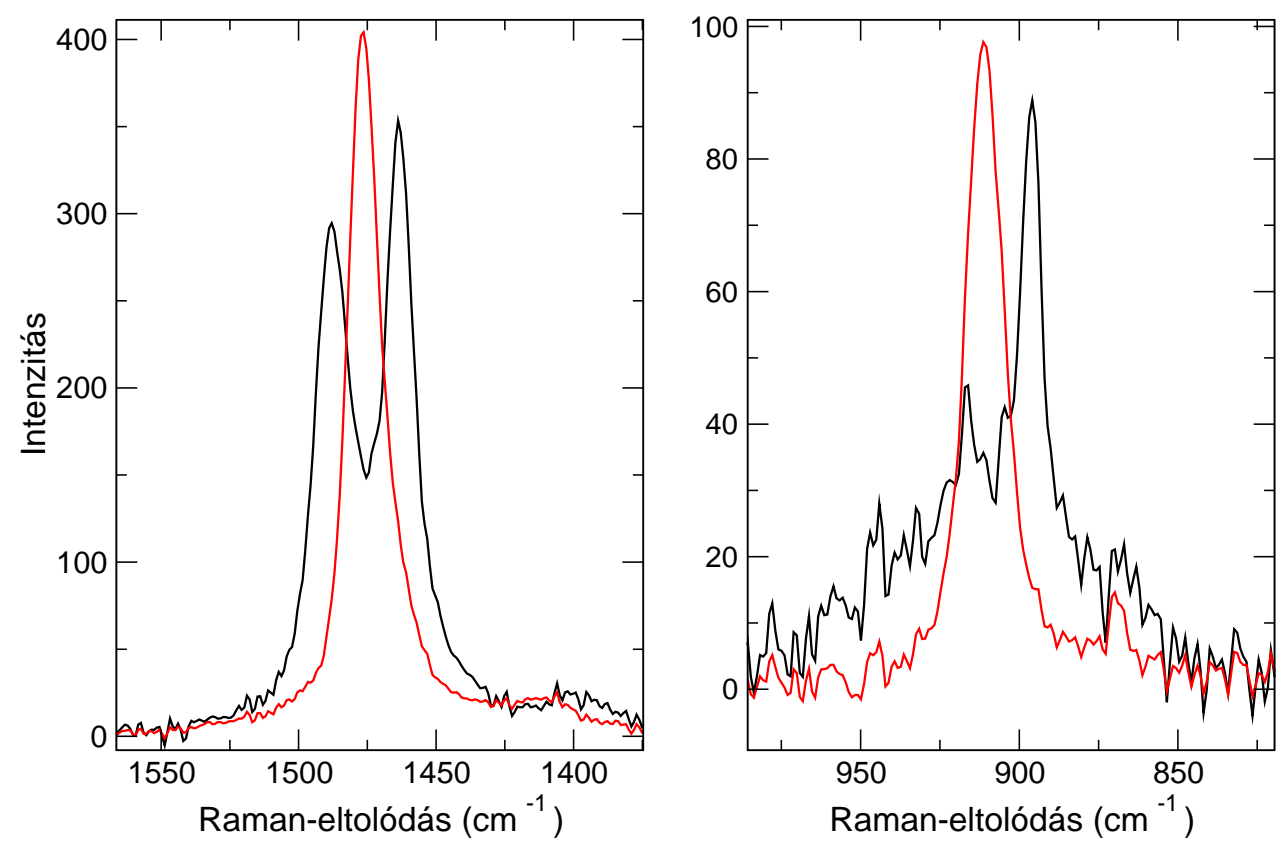

5.14. ábra. A kalcium-oxalát áramlásvezérelt körülmények között képződött egyedi részecskék Raman-spektruma. A fekete görbe az 5.13. A ábrán lévő részecskéhez tartozó színkép (COM), míg a piros görbe az 5.13. B ábrán lévő részecske spektruma (COD). 
Az 5.14. ábrán az 1400-1500 cm cm $^{-1}$ közötti tartományban a szimmetrikus C-O nyújtórezgés látható, amely a kalcium-oxalát-dihidrát esetében (piros görbe) egy darab ekvivalens sáv. A $900 \mathrm{~cm}^{-1}$ körüli tartományon pedig a $\mathrm{C}-\mathrm{C}$ nyújtórezgés látható, a COM (fekete görbe) esetén kisebb hullámszám értéknél.

Kihasználva a Raman-mikroszkóp adta lehetőségeket, egy térképet is készítettünk, a $20 \mathrm{~cm}^{3} \cdot \mathrm{h}^{-1}$ térfogat-áramlási sebességgel előállított csapadékról. Az 5.18. ábra igazolja, hogy a kétféle kristályvizes forma egyszerre van jelen, de elkülönülten kristályosodik. A térképet úgy készítettük, hogy a két legintenzívebb hullámhosszon detektált a készülék (1463 és $1477 \mathrm{~cm}^{-1}$ ), és a megfelelố területet megszínezte. Pirossal a kalcium-oxalát-dihidrátot jelöltem.

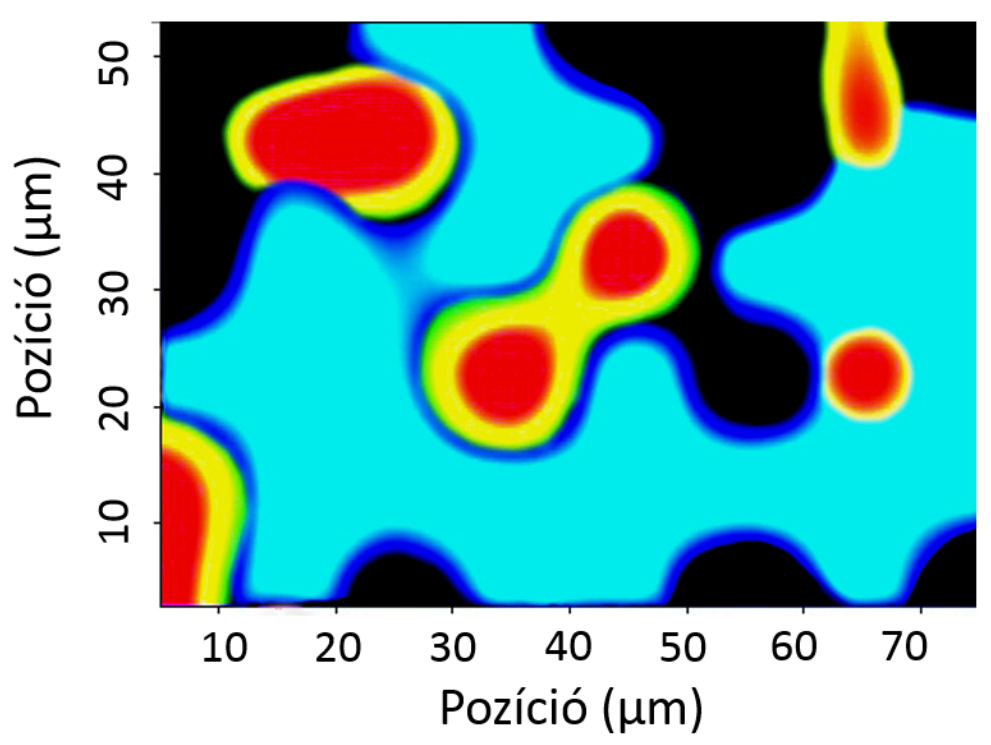

5.15. ábra. Az áramlásvezérelt körülmények között képződött kalcium-oxalát részecskék Raman-mikroszkóppal detektált eloszlása (fekete a háttér, piros a kalcium-oxalát dihidrát, míg kék a kalcium-oxalát monohidrát). A kísérleti paraméterek: $c\left(\mathrm{CaCl}_{2}\right)=4,0 \mathrm{~mol} \cdot \mathrm{dm}^{-3}$, $c\left(\mathrm{Na}_{2} \mathrm{C}_{2} \mathrm{O}_{4}\right)=0,025 \mathrm{~mol} \cdot \mathrm{dm}^{-3}, \mathrm{pH}=9,0$, és $q_{\mathrm{V}}=20 \mathrm{~cm}^{3} \cdot \mathrm{h}^{-1}$. 


\subsection{Pásztázó elektronmikroszkópiás felvételek}

A jól kevert rendszerben előállított csapadékrészecskék pásztázó elektronmikroszkópiás felvételét az 5.16. A ábrán tüntettem fel: méretük jóval kisebb, mint $1 \mu \mathrm{m}$, formájuk lekerekített. Az áramlásvezérelt körülmények között képződött csapadékminták mikrostruktúrája az 5.16. B-F ábrán látható.
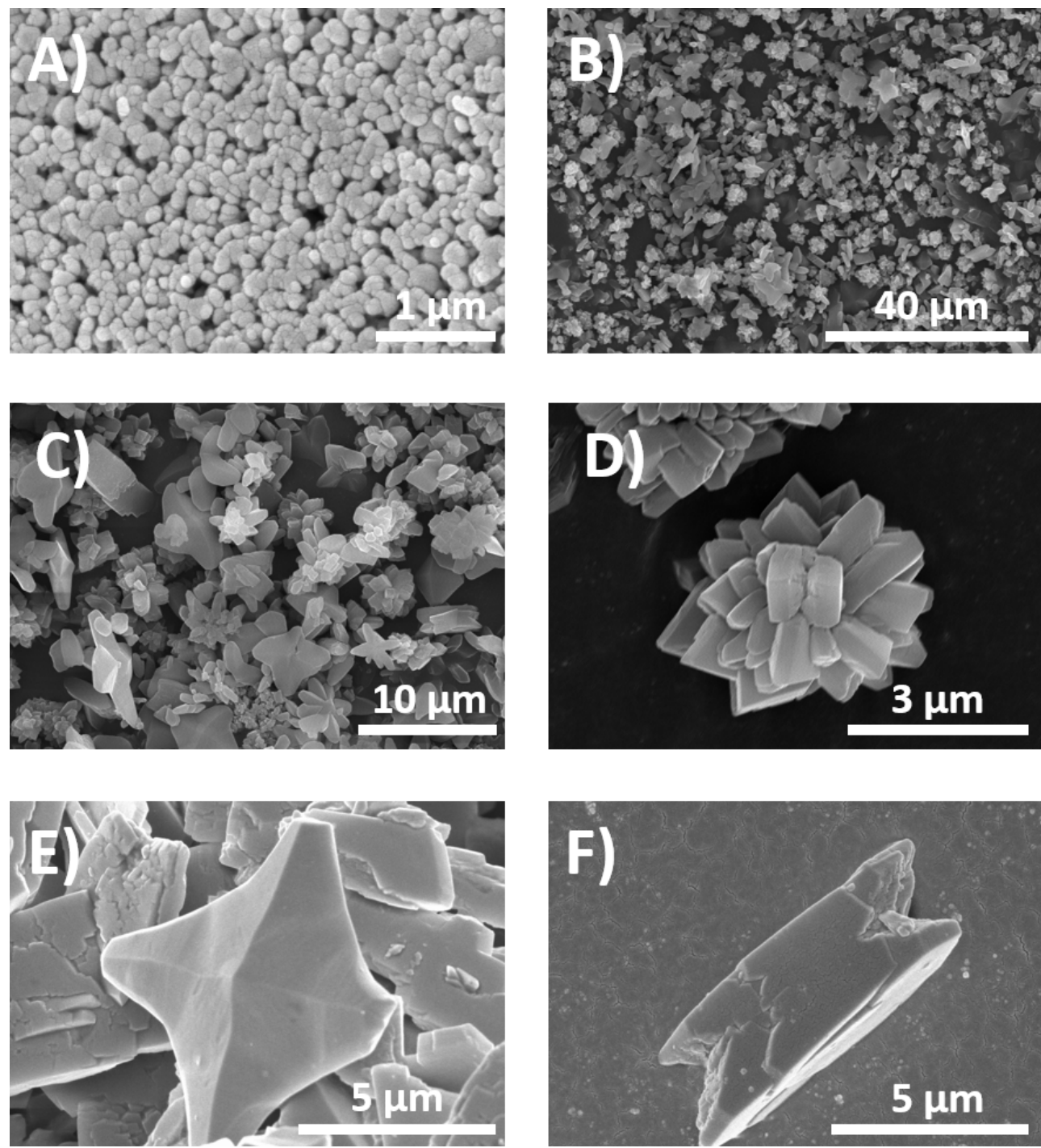

5.16. ábra. A jól kevert minta (A), és az áramlásvezérelt körülmények között keletkezett csapadékminta jellegzetes pásztázó elektronmikroszkópiás képe (B-F). Az áramlásvezérelt kísérletek esetében a kísérleti paraméterek: $c\left(\mathrm{CaCl}_{2}\right)=4,0 \mathrm{~mol} \cdot \mathrm{dm}^{-3}, c\left(\mathrm{Na}_{2} \mathrm{C}_{2} \mathrm{O}_{4}\right)=$ $0,025 \mathrm{~mol} \cdot \mathrm{dm}^{-3}, \mathrm{pH}=9,0$, és $q_{\mathrm{V}}=20 \mathrm{~cm}^{3} \cdot \mathrm{h}^{-1}$.

A képeket szemlélve rögtön szembetűnik a méretbeli különbség (5.16. B és C ábra): az áramlásvezérelt rendszerben (akár a szálakban, akár a szálak közötti térben, akár a belsô kevesebb csapadékot tartalmazó korongból is vettem a mintát), a részecskék mérete $\mu \mathrm{m}$ feletti. A $20 \mathrm{~cm}^{3} \cdot \mathrm{h}^{-1}$ térfogat-áramlási sebességgel a $0,025 \mathrm{~mol} \cdot \mathrm{dm}^{-3}$ koncentrációjú nátrium-oxalát-oldatba $(\mathrm{pH}=9,0)$ áramoltatott $4,0 \mathrm{~mol} \cdot \mathrm{dm}^{-3}$ koncentrációjú kalcium- 
klorid-oldatból kapott csapadékot az 5.16. D, E és F ábrán bemutatott rózsaszerú, oktaéderes, és hosszúkás képződmények jellemzik. A kialakult rózsák átlagos mérete a mintavétel helyén, a betáplálástól kb. $6 \mathrm{~cm}$-es távolságban, $3 \mu \mathrm{m}$, de a rózsákon kívül a mintában kisebb mennyiségben előforduló, $5 \mu \mathrm{m}$-nél nagyobb pillangó vagy oktéderes részecskéket is megfigyeltem. A belső és a külső kör, valamint a különböző pH-jú minták részecskéinek alakja között nem figyeltem meg változást.

A Raman-mikroszkóp korlátozott felbontása miatt leginkább a pásztázó elektronmikroszkóp segítségével figyelhetjük meg a monohidrát és dihidrát kristályokat. A jól kevert rendszerben hasábra vagy rózsára emlékeztetố alakkal rendelkező kalcium-oxalát-monohidrát részecskék képződtek (kinagyított felvételek láthatóak az 5.17. ábrán).
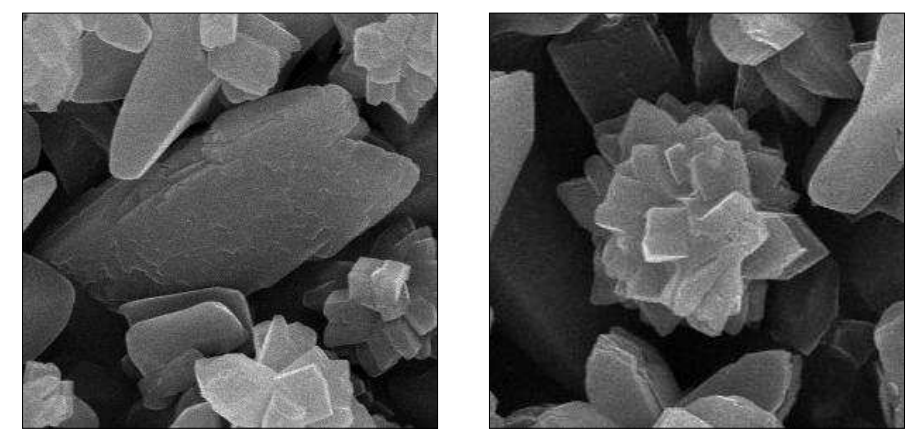

5.17. ábra. A kalcium-oxalát-monohidrát részecskék pásztázó elektronmikroszkópiás felvétele. A képek szélessége 8,4 és 7,0 $\mu \mathrm{m}$.

Az áramlásvezérelt körülmények között képződött bipiramisos vagy pillangóra emlékeztető kalcium-oxalát-dihidrát részecskérôl készült felvételek láthatóak az 5.18. ábrán kinagyítva.
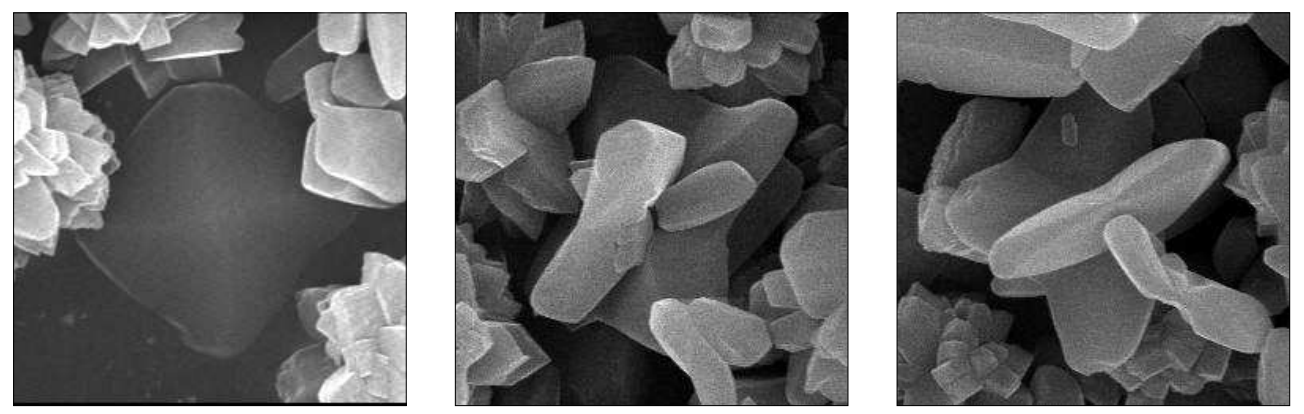

5.18. ábra. A kalcium-oxalát-dihidrát részecskék pásztázó elektronmikroszkópiás felvétele. A képek szélessége 7,0 $\mu \mathrm{m}$.

A megnövelt sûrűségû és viszkozitású folyadékokból előállított csapadékok mikroszerkezetét is tanulmányoztuk pásztázó elektronmikroszkóppal (5.19. ábra). A $0,5 \mathrm{~mol} \cdot \mathrm{dm}^{-3}$ koncentrációjú nátrium-kloridot tartalmazó minta belsô köre x-szerú részekből állt inkább, melyek mérete $15 \mu \mathrm{m}$, míg a külső körben rózsaszerú képződmények találhatók, melyek mérete $6 \mu \mathrm{m}$, nagyobbak, mint a nátrium-kloridot nem tartalmazó mintáké. 

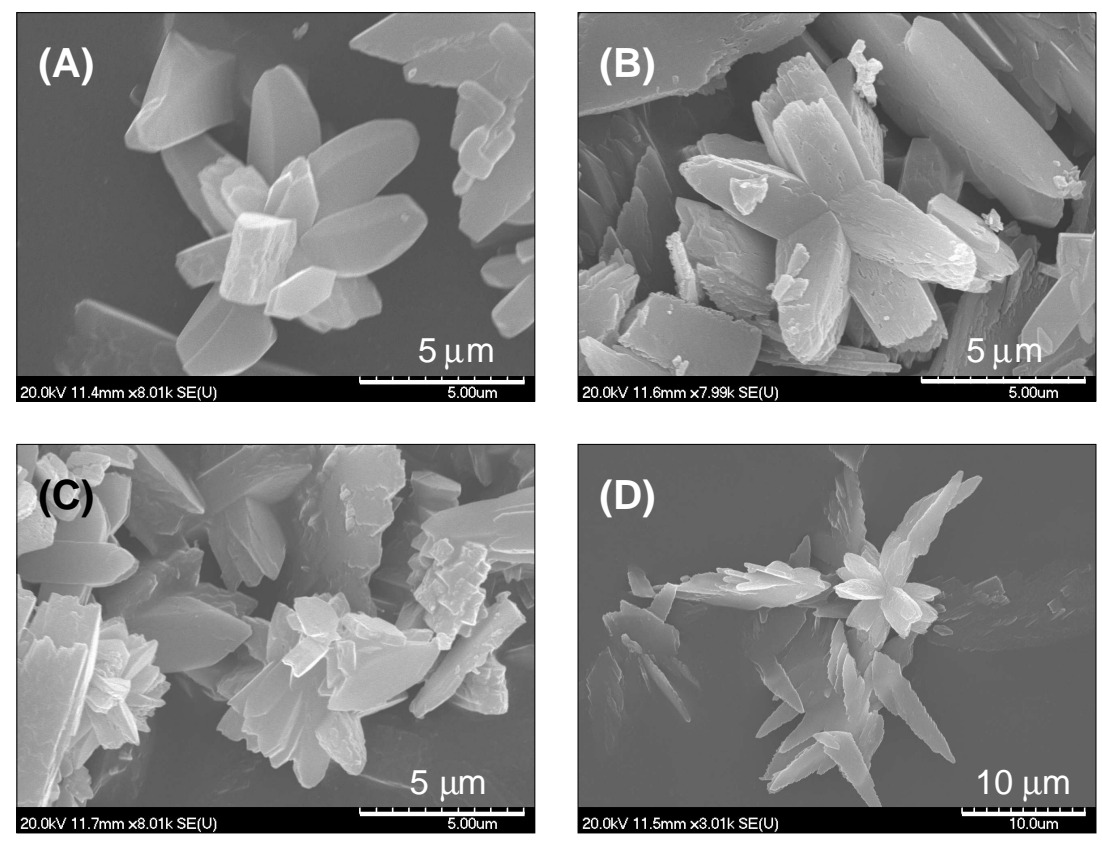

5.19. ábra. A $0,5 \mathrm{~mol} \cdot \mathrm{dm}^{-3}$ nátrium-kloridot (A), a $2 \mathrm{~mol} \cdot \mathrm{dm}^{-3}$ glicerint (B), az $0,1 \mathrm{~g} \cdot \mathrm{cm}^{-3}$ poli(vinil-alkohol)-t (C) és a $0,3 \mathrm{~g} \cdot \mathrm{cm}^{-3}$ poliakrilamidot (D) tartalmazó minták külső körének pásztázó elektronmikroszkópiás felvétele. Kísérleti körülmények megegyeznek az előző képekével.

A jól kevert és az áramlásvezérelt kísérletekből származó, $1000{ }^{\circ} \mathrm{C}$ hőmérsékletưre felhevített kalcium-oxiddá alakult mintákat is megvizsgáltam. Az áramlás hatására létrejött részecskék hevítés után lekerekített formát vettek fel, melyről készült felvétel az 5.20. A ábrán található. A jól kevert rendszerből származó hevített minta $20 \mu \mathrm{m}$ méretú négyzet alakú részecskékból áll, mely az 5.20. B ábrán látható. Megfigyelhetjük, hogy ez a minta jelentősen nagyobb méretú részeket tartalmaz, mint a hevítés nélküli.
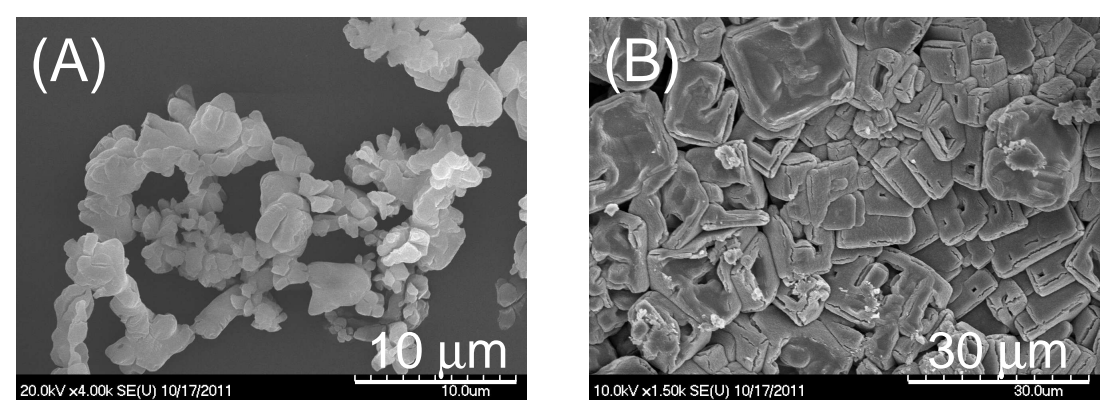

5.20. ábra. Pásztázó elektronmikroszkópiás felvételek az áramlásvezérelt körülmények között kialakult csapadék külső köréből (A) és a jól kevert rendszerből származó mintáról (B) $1000{ }^{\circ} \mathrm{C}$-ra hevítést követően. 


\section{6. fejezet}

\section{Kalcium-karbonát csapadékmintázat}

\subsection{A koncentrációeloszlás számítása}

A lehetséges komponensek arányát egyensúlyi számításokkal határoztam meg a pH függvényében az alábbi reakciók figyelembevételével [122].

A kalcium-karbonát csapadék leválása:

$$
\mathrm{CaCO}_{3}(\mathrm{sz}) \rightleftharpoons \mathrm{Ca}^{2+}(\mathrm{aq})+\mathrm{CO}_{3}^{2-}(\mathrm{aq}) \quad \mathrm{p} K_{\mathrm{SP}}=8,35
$$

A kalcium-hidroxid csapadék leválása:

$$
\mathrm{Ca}(\mathrm{OH})_{2}(\mathrm{sz}) \rightleftharpoons \mathrm{Ca}^{2+}(\mathrm{aq})+2 \mathrm{OH}^{-}(\mathrm{aq}) \quad \mathrm{p} K_{\mathrm{SP}}=5,10
$$

Különböző komplexképződési reakciók a kalciumionnal:

$$
\begin{aligned}
\mathrm{Ca}^{2+}(\mathrm{aq})+\mathrm{OH}^{-}(\mathrm{aq}) & \rightleftharpoons \mathrm{CaOH}^{+}(\mathrm{aq}) & & \lg \beta_{\mathrm{OH}}=1,15 \\
\mathrm{Ca}^{2+}(\mathrm{aq})+\mathrm{CO}_{3}^{2-}(\mathrm{aq}) & \rightleftharpoons \mathrm{CaCO}_{3}(\mathrm{aq}) & & \lg \beta_{1}=3,15 \\
\mathrm{Ca}^{2+}(\mathrm{aq})+\mathrm{HCO}_{3}^{-}(\mathrm{aq}) & \rightleftharpoons \mathrm{CaHCO}_{3}^{+}(\mathrm{aq}) & & \lg \beta_{\mathrm{H}_{1}}=1,00
\end{aligned}
$$

A karbonátion protonálódási folyamatai:

$$
\begin{aligned}
\mathrm{H}^{+}(\mathrm{aq})+\mathrm{CO}_{3}^{2-}(\mathrm{aq}) & \rightleftharpoons \mathrm{HCO}_{3}^{-}(\mathrm{aq}) & & \lg K_{\mathrm{H}_{1}}=10,33 \\
\mathrm{H}^{+}(\mathrm{aq})+\mathrm{HCO}_{3}^{-}(\mathrm{aq}) & \rightleftharpoons \mathrm{H}_{2} \mathrm{CO}_{3}(\mathrm{aq}) & & \lg K_{\mathrm{H}_{2}}=6,35
\end{aligned}
$$

A számításokat a $\mathrm{pH}=1-14$ tartományban, $4,0 \mathrm{~mol} \cdot \mathrm{dm}^{-3}$ teljes kalciumion- és $0,01 \mathrm{~mol} \cdot \mathrm{dm}^{-3}$ teljes karbonátion koncentrációkkal végeztem, 0,01 pH-egység lépésközönként. A numerikus számolásokhoz $10^{-14}$ relatív hibát állítottam be. Ebben az elegyben a pH függvényében két különböző csapadék alakul ki, a (6.1) és a (6.2) egyenleteknek megfelelôen, így három futtatást kellett indítanom. Az elsốt a homogén rendszerre $\mathrm{pH}=0,00-5,13$ 
között, egyet a kalcium-karbonát csapadék leválásakor $\mathrm{pH}=5,14-11,11$ között, valamint az utolsót $\mathrm{pH}=11,12-14,00$ között, mely során a következó egyenleteket definiáltam, figyelembe véve, hogy a kalciumion mennyisége nagy:

$$
\begin{aligned}
{\left[\mathrm{Ca}^{2+}\right] } & =K_{\mathrm{SP}}\left(\mathrm{Ca}(\mathrm{OH})_{2}\right) \cdot \frac{\left[\mathrm{H}^{+}\right]^{2}}{\mathrm{~K}_{\mathrm{V}}^{2}} \\
{\left[\mathrm{HCO}_{3}^{-}\right] } & =\frac{K_{\mathrm{SP}}\left(\mathrm{CaCO}_{3}\right) \cdot\left[\mathrm{H}^{+}\right] \cdot \mathrm{K}_{\mathrm{H}_{1}}}{\left[\mathrm{Ca}^{2+}\right]}
\end{aligned}
$$

A harmadik futtatás bemeneti adatait tartalmazó fájlja a Függelék III.1. fejezetében található.

A 6.1. ábrán látható diagram a részecskék eloszlását mutatja be. Savas oldatban a reaktánsok koncentrációinak szorzata nem éri el az oldhatósági szorzatot, így még nem válik le csapadék. A kalcium-karbonát $\mathrm{pH}=5,14$-nél, míg kalcium-hidroxid $\mathrm{pH}=11,11$-nél jelenik meg. A kalcium-karbonát csapadék mennyisége nem állandó érték, maximumot ér el 11,27 pH-értéknél. Számításaink szerint a különböző kalciumion-, és karbonátiontartalmú komplexek kis mennyiségben vannak jelen az oldatban.

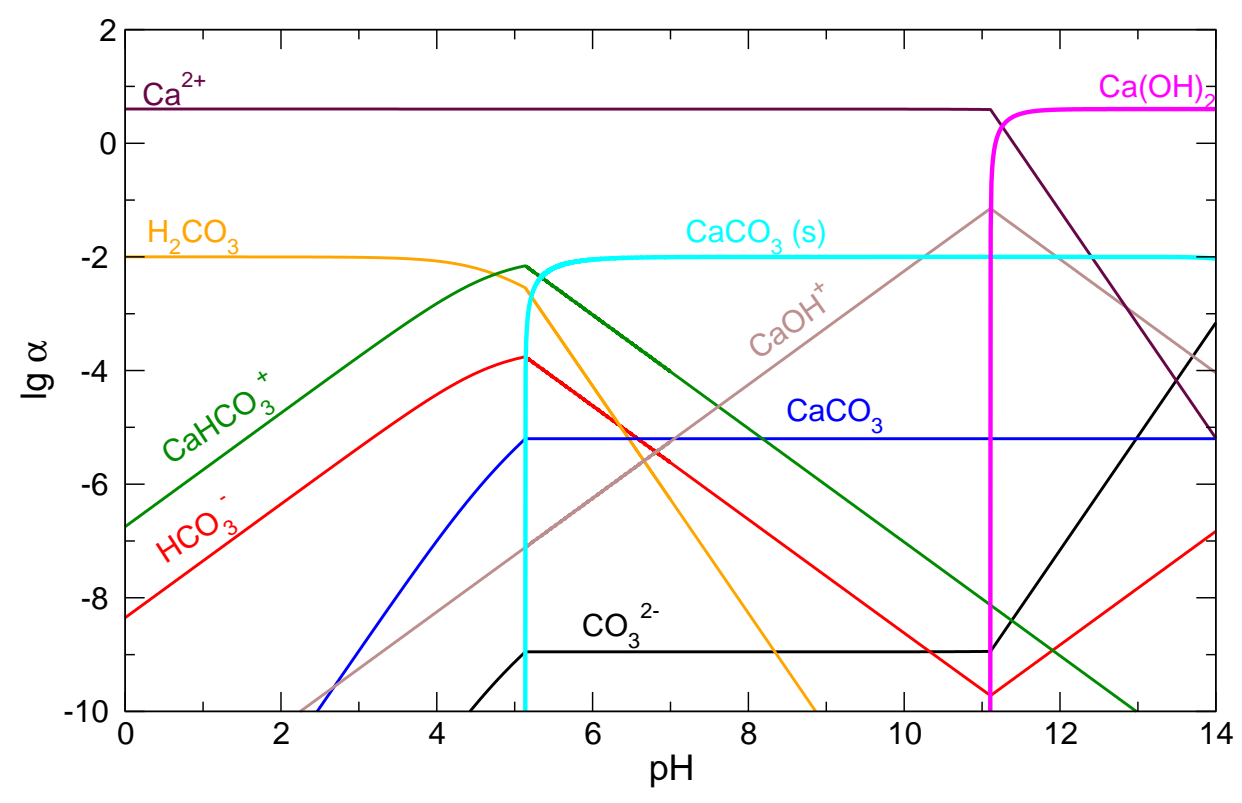

6.1. ábra. Egyensúlyi számítások: a komponensek aránya $(\alpha)$ a pH függvényében. A kétféle csapadékot (kalcium-karbonát és kalcium-hidroxid) vastagított vonallal jelöltem az ábrán. 


\subsection{A mintázat jellemzése}

Jól kevert rendszerben a reaktánsok összeöntésekor a csapadék pillanatszerú megjelenését tapasztaltam, függetlenül attól, hogy melyik reagens feleslegébe adagoltam a másikat.

Ha kalcium-klorid-oldatot áramoltattam nátrium-karbonát-oldatba, akkor a reaktánsok koncentrációjától függően vagy szabályos kör alakú vagy szabálytalan alakzatokat figyeltem meg. A kalcium-karbonát csapadék mintázata (6.2. ábra), nagyon hasonlóan a kalciumoxalát csapadék mintázatához, mivel mindkettő tartalmaz a betáplálás helye körül egy csapadékrészecskékkel szegényebben borított belsô kört valamint egy külsô gyưrût is. A szabályos kalcium-karbonát mintázatoknál azonban a belső kör körül és a csapadék pereménél is található egy fehérebb gyưrú, amelyek élesen elhatárolódnak a többi résztôl. A szálak a kalcium-karbonát esetén nem, vagy csak a peremén jelennek meg, szabad szemmel láthatóak, de a felvételeken alig észrevehetôek.

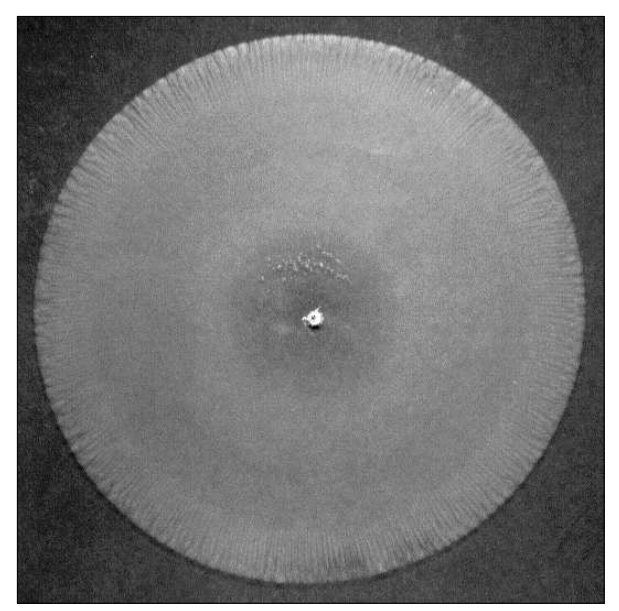

6.2. ábra. A kalcium-karbonát mintázat fényképe $t=4$ min idôpontban. A kalcium-kloridoldat koncentrációja $4 \mathrm{~mol} \cdot \mathrm{dm}^{-3}$, a $\mathrm{pH}=10,0$ kémhatású nátrium-karbonát-oldat koncentrációja pedig $0,01 \mathrm{~mol} \cdot \mathrm{dm}^{-3}$. A kép eredeti szélessége $17,0 \mathrm{~cm}$.

A koncentrációeloszlási görbékből jól látható, hogy $\mathrm{pH}=5$ felett jelenik meg a kalciumkarbonát csapadék, $\mathrm{pH}=11$ felett pedig a kalcium-hidroxid csapadék a meghatározó a rendszerben. Kísérleteinket ezért olyan pH-tartományban végeztem, ahol csupán a kalciumkarbonát csapadék leválása valószínúsíthető, de ezt a tényt késôbbi fejezetek során szerkezetvizsgáló módszerek bevetésével igazolni is fogom. Ennek érdekében nátrium-karbonátból pH = 10,0 kémhatású, 0,1-0,01 $\mathrm{mol} \cdot \mathrm{dm}^{-3}$ koncentrációjú oldatokat készítettem.

A 6.3. ábrán a kalcium-klorid és a nátrium-karbonát-oldat koncentráció változtatásának hatása látható. Ha csökken a nátrium-karbonát-oldat koncentrációja, akkor nô a reaktánsoldatok közötti sûrúségkülönbség, ami nagyobb sugarú, és vékonyabb, szabályosabb csapadékréteg kialakulását eredményezi. A szabályos mintázat létrejöttének a kalcium-kloridoldat koncentrációjának növelése kedvez. Megállapítottuk, hogy a nagyobb súrúségkülönbség okozza a szabályosabb és nagyobb méretư mintázat kialakulását (6.1. táblázat). 


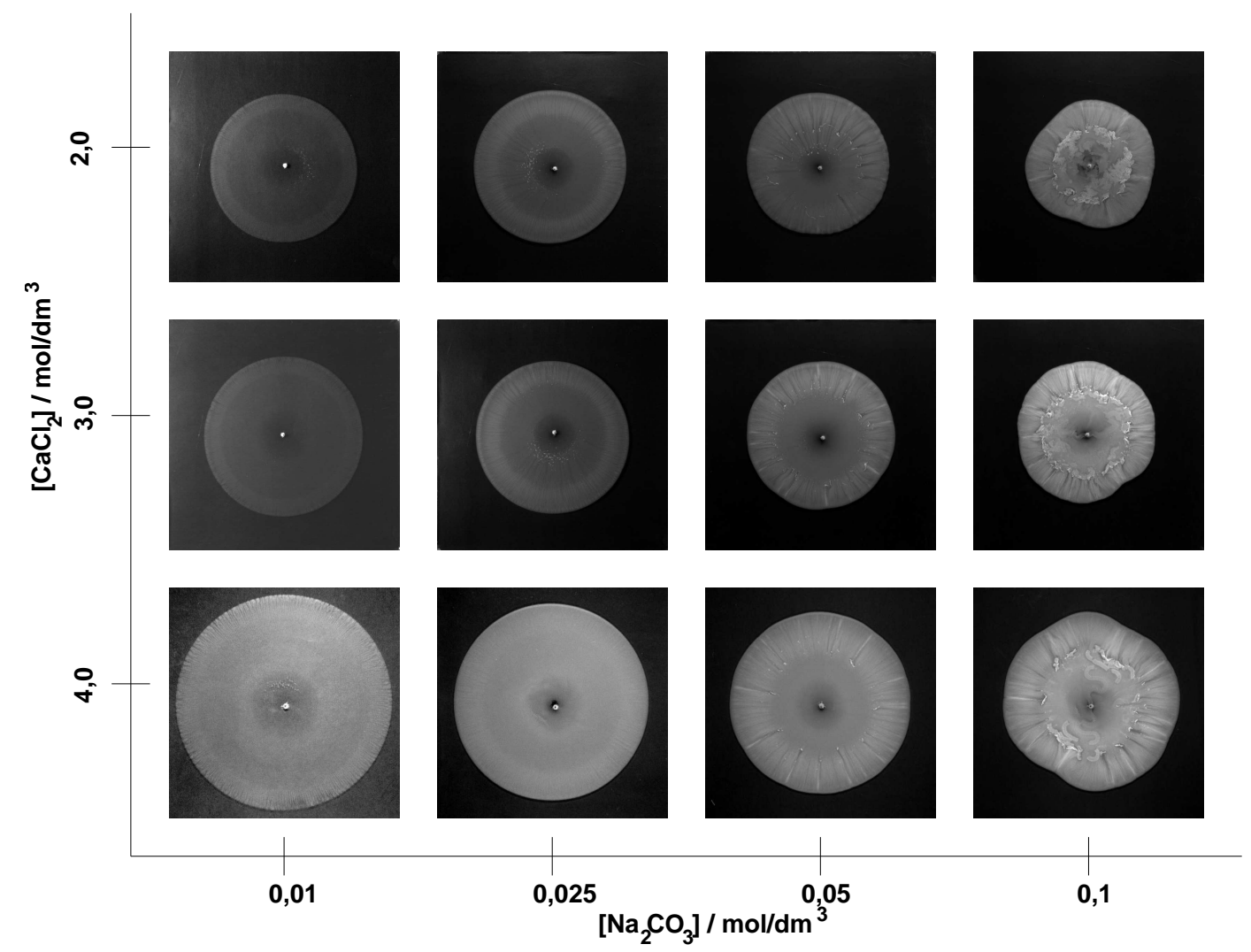

6.3. ábra. Kalcium-karbonát mintázatok fényképe $t=4$ min idôpontban. A képeken látható terület $18 \mathrm{~cm} \times 18 \mathrm{~cm}$. A kísérleti paraméterek: $\mathrm{pH}=10,0$, és $q_{\mathrm{V}}=20 \mathrm{~cm}^{3} \cdot \mathrm{h}^{-1}$.

A $0,1 \mathrm{~mol} \cdot \mathrm{dm}^{-3}$ koncentrációjú nátrium-karbonát-oldattal elvégzett kísérletben létrejövő csapadék szabálytalan alakú, az áramlásnak a mintázatra gyakorolt hatása összetett. A mintázat felett kisebb csövek is kifejlődjenek, mely arra enged következtetni, hogy már nincs elegendôen nagy sưrúségkülönbség a két reaktánsoldat között, és a csapadéknak nem csak vízszintes, hanem függőleges irányú növekedése is megvalósul. Ha adott (például 4,0 $\mathrm{mol} \cdot \mathrm{dm}^{-3}$ ) kalcium-klorid-oldat koncentráció mellett csökkentettem a nátriumkarbonát-oldat koncentrációját, akkor azt tapasztaltam, hogy nő a belsô és a külső kör mérete lásd a 6.2. táblázatot.

6.1. táblázat. A fázisdiagram pontjaihoz tartozó számított sűrûségkülönbség értékek, melyeket a $\Delta \rho=\rho\left(\mathrm{CaCl}_{2}\right)-\rho\left(\mathrm{Na}_{2} \mathrm{CO}_{3}\right)$ egyenlet segítségével adtam meg $\mathrm{g} \cdot \mathrm{cm}^{-3}$ egységben.

\begin{tabular}{ccccc}
\hline \hline kalcium-klorid & \multicolumn{4}{c}{ nátrium-karbonát $\left(\mathrm{mol} \cdot \mathrm{dm}^{-3}\right)$} \\
$\left(\mathrm{mol} \cdot \mathrm{dm}^{-3}\right)$ & 0,010 & 0,025 & 0,050 & 0,100 \\
\hline 2,0 & 1,1566 & 0,1565 & 0,1535 & 0,1487 \\
3,0 & 0,2147 & 0,2146 & 0,2116 & 0,2068 \\
4,0 & 0,3313 & 0,3312 & 0,3282 & 0,3234 \\
\hline \hline
\end{tabular}


A beáramló oldat térfogatának ismeretében a csapadékkorong felszínéből meghatároztam a gravitációs áram átlagos magasságát, ami a nátrium-karbonát-oldat koncentrációjának emelkedésével nôtt. Egy újabb fehér gyưrú jelent meg halványan a mintázatban 0,025 $\mathrm{mol} \cdot \mathrm{dm}^{-3}$-re csökkentett nátrium-karbonát-oldat koncentráció alkalmazásánál. Ez a fehér gyứrú tovább erôsödött a $0,01 \mathrm{~mol} \cdot \mathrm{dm}^{-3}$ koncentrációjú nátrium-karbonát-oldatot felhasználó kísérletek során.

6.2. táblázat. A koncentráció változtatásának hatása a csapadék paramétereire. A kísérleti paraméterek: $\mathrm{pH}=10,0, q_{\mathrm{V}}=20 \mathrm{~cm}^{3} \cdot \mathrm{h}^{-1}$.

\begin{tabular}{ccccc}
\hline \hline \multicolumn{2}{c}{ koncentrációk } & \multicolumn{3}{c}{ a mintázat jellemzó paraméterei } \\
$\begin{array}{c}\mathrm{CaCl}_{2} \\
\left(\mathrm{~mol} \cdot \mathrm{dm}^{-3}\right)\end{array}$ & $\begin{array}{c}\mathrm{Na}_{2} \mathrm{CO}_{3} \\
\left(\mathrm{~mol} \cdot \mathrm{dm}^{-3}\right)\end{array}$ & $\begin{array}{c}r_{\mathrm{b}} \\
(\mathrm{mm})\end{array}$ & $\begin{array}{c}r_{\mathrm{k}} \\
(\mathrm{mm})\end{array}$ & $\begin{array}{c}\bar{h} \\
(\mathrm{~mm})\end{array}$ \\
\hline 4 & 0,010 & $23(2,0)$ & $77(1,0)$ & 0,07 \\
4 & 0,025 & $20(1,1)$ & $75(0,4)$ & 0,08 \\
4 & 0,050 & $17(1,1)$ & $68(0,9)$ & 0,09 \\
3 & 0,010 & $25(3,7)$ & $84(4,1)$ & 0,15 \\
3 & 0,025 & $22(1,9)$ & $81(0,8)$ & 0,16 \\
3 & 0,050 & $14(1,4)$ & $59(0,9)$ & 0,16 \\
2 & 0,010 & $21(2,4)$ & $76(1,4)$ & 0,18 \\
2 & 0,025 & $20(0,7)$ & $74(3,0)$ & 0,20 \\
2 & 0,050 & - & $68(0,8)$ & 0,21 \\
\hline \hline
\end{tabular}




\subsection{A külsố csapadékkör méretének változása a reakció idốtartama alatt}

Vizsgáltam a $20 \mathrm{~cm}^{3} \cdot \mathrm{h}^{-1}$ térfogat-áramlási sebességen, $4,0 \mathrm{~mol} \cdot \mathrm{dm}^{-3}$ kalcium-kloridoldat és $0,025 \mathrm{~mol} \cdot \mathrm{dm}^{-3}$ nátrium-oxalát-oldat koncentrációkkal elvégzett kísérletekben a kialakult csapadékmintázat méretének időbeli változását. A 6.4. ábrán a pontok segítségével ábrázoltam a külső kör sugarának növekedését az idô függvényében. Egyértelmú, hogy ez a növekedés egyre kevésbé intenzív az idő előrehaladásával, hiszen állandó térfogat-áramlási sebesség mellett a mintázat egyre nagyobb térrészt foglal el, azaz a sebesség csökken.

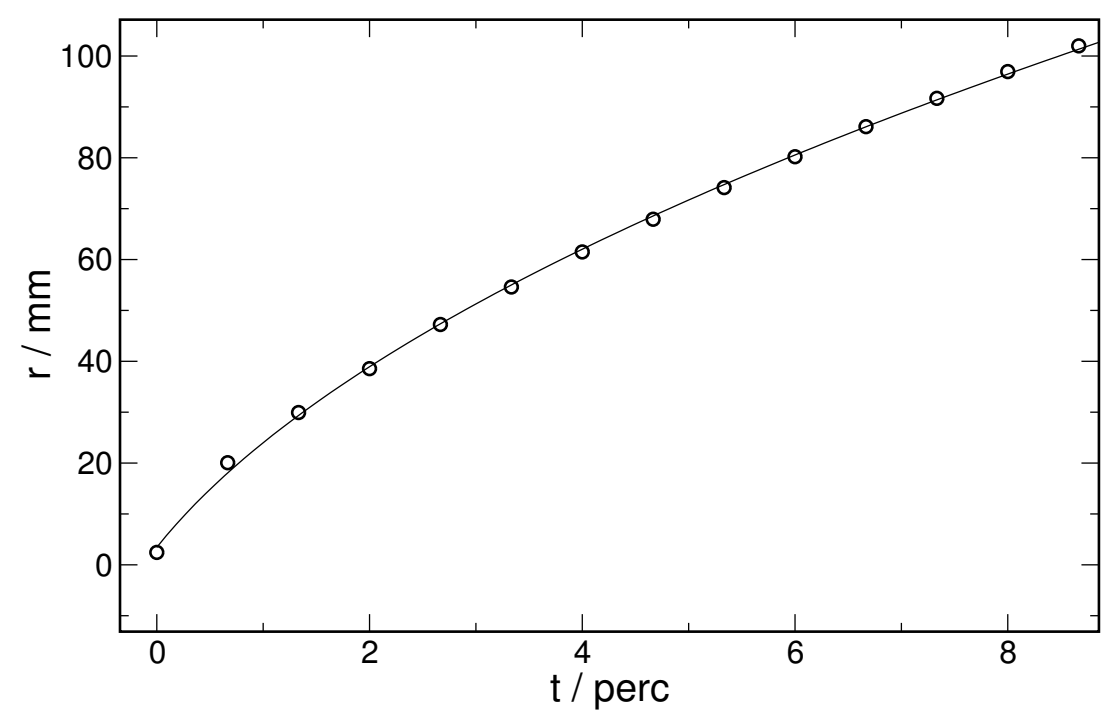

6.4. ábra. A kalcium-karbonát csapadékmintázat sugarának növekedése. A pontok a kísérleti adatokat, míg a folytonos vonal az illesztett függvényt jelöli. A kísérleti paraméterek: $c\left(\mathrm{CaCl}_{2}\right)=4,0 \mathrm{~mol} \cdot \mathrm{dm}^{-3}, c\left(\mathrm{Na}_{2} \mathrm{CO}_{3}\right)=0,025 \mathrm{~mol} \cdot \mathrm{dm}^{-3}, \mathrm{pH}=10$, és $q_{\mathrm{V}}=20 \mathrm{~cm}^{3} \cdot \mathrm{h}^{-1}$.

A kísérleti adatokra (az 5.10) háromparaméteres egyenletet illesztettem (lásd a Függelék III.2. fejezetét). Az illesztés paraméterei: $a_{0}=44,0 \pm 0,9 \mathrm{~mm} \cdot \mathrm{s}^{-1} ; a_{1}=0,7 \pm 0,1 \mathrm{~s}$; $a_{2}=-33 \pm 3 \mathrm{~mm}$. A 6.4. ábrán folytonos vonallal jelölve láthatjuk az illesztett egyenletet, tehát a közel négyzetgyökös függés igaznak bizonyul, ezáltal azt is igazoltam, hogy a pillanatszerú csapadékképződés folyamatosan követi a sugárirányban terjedő nagy sûrúségú folyadék útját. 


\subsection{Termogravimetriás analízis}

A kiszárított csapadékot az összegyújtést követően termogravimetriás analízisnek vetettük alá. A 6.5. ábrán a jól kevert rendszerből származó porminta TG- és DTG-görbéje látható. Elsôként a megkötött víz távozik, majd a görbén elkülönülő lépcsôben az oxidképzôdés következik be:

$$
\mathrm{CaCO}_{3}(\mathrm{sz}) \longrightarrow \mathrm{CaO}(\mathrm{sz})+\mathrm{CO}_{2}(\mathrm{~g})
$$

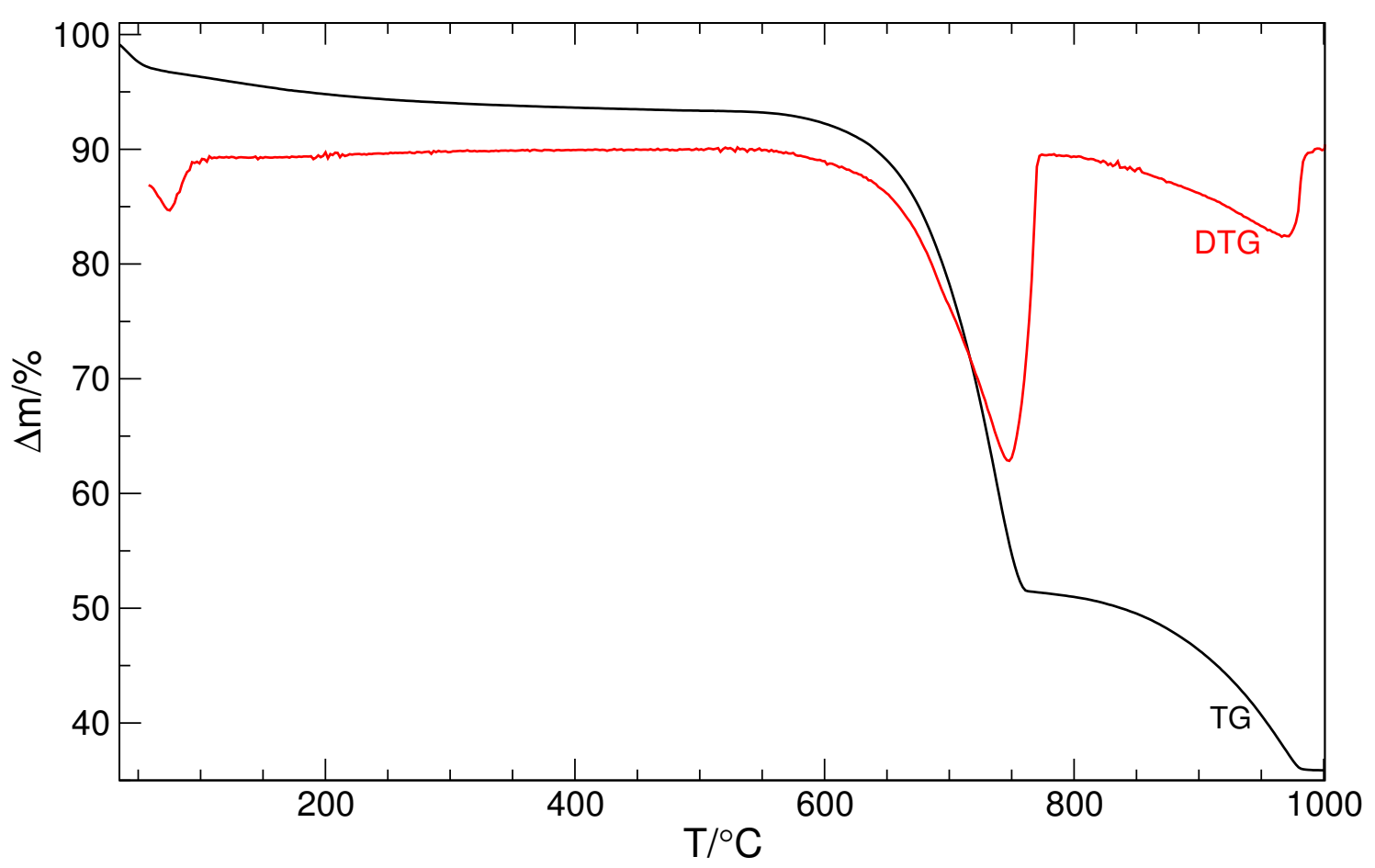

6.5. ábra. A jól kevert rendszer TG-, és DTG-görbéje. A kísérleti paraméterek: $c\left(\mathrm{CaCl}_{2}\right)=$ $4,0 \mathrm{~mol} \cdot \mathrm{dm}^{-3}, c\left(\mathrm{Na}_{2} \mathrm{CO}_{3}\right)=0,025 \mathrm{~mol} \cdot \mathrm{dm}^{-3}$, és $\mathrm{pH}=10$.

Az elméleti és gyakorlati százalékos tömegveszteségek jó egyezést mutattak. Megállapítottuk, hogy az áramlásvezérelt és a jól kevert rendszer kémiai összetétele között nincsen kristályvíztartalomból származó eltérés (6.3. táblázat). További vizsgálatok szükségesek ahhoz azonban, hogy kiderítsük, vajon a morfológia is azonos-e.

6.3. táblázat. A kalcium-karbonát csapadékok tömegveszteségei.

\begin{tabular}{lc}
\hline \hline kiindulási anyag, állapot & $\Delta m_{900}{ }^{\circ} \mathrm{C}(\%)$ \\
\hline elméleti (számolt) & 44,00 \\
kísérleti jól kevert & 43,97 \\
kísérleti áramlásvezérelt $\left(20 \mathrm{~cm}^{3} \cdot \mathrm{h}^{-1}\right)$ & 44,00 \\
\hline \hline
\end{tabular}

A kalcium-karbonát minta porsưrúsége $2,70 \mathrm{~g} \cdot \mathrm{cm}^{-1}$. 


\subsection{A mikroszerkezet és a méreteloszlás vizsgálata}

A kísérleti részben leírt módon kiszárított áramlásvezérelt és jól kevert csapadékokból mintákat vettem, hogy optikai és pásztázó elektronmikroszkópiás felvételeket készítsek. Az áramlásvezérelt csapadék esetében a szálakról, a szálak közötti részből, a belső kevés csapadékot tartalmazó korongból és az amellett elhelyezkedô gyưrút alkotó kristályokról is készítettem felvételeket. A jól kevert körülmények között kialakult csapadékban romboéderek, néhol a kevésbé szabályos téglatestek mellett gömbszerü részecskéket is megfigyeltem (6.6. ábra).
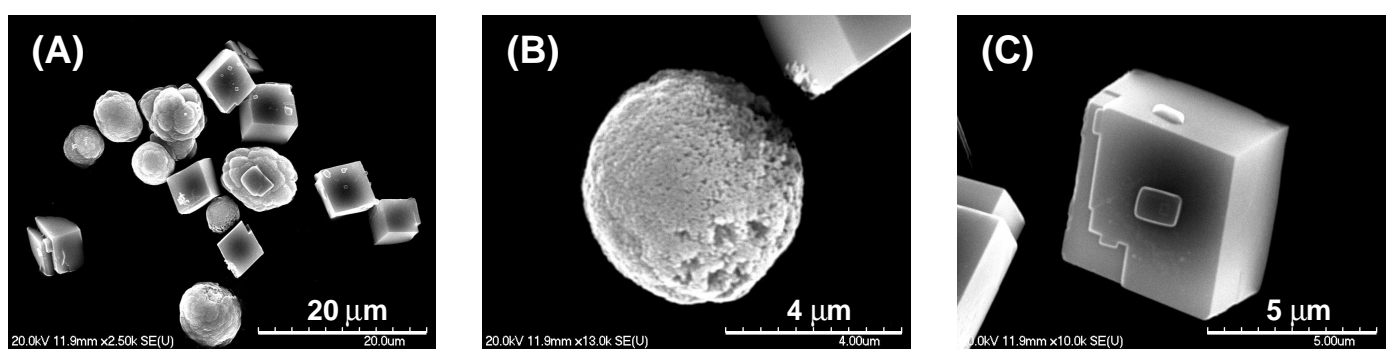

6.6. ábra. A jól kevert rendszer pásztázó elektronmikroszkópiás felvétele (A), a kialakult gömbszerú $(\mathrm{B})$ és romboéder $(\mathrm{C})$ alakú részecskék. A kísérleti paraméterek: $c\left(\mathrm{CaCl}_{2}\right)=$ $4,0 \mathrm{~mol} \cdot \mathrm{dm}^{-3}, c\left(\mathrm{Na}_{2} \mathrm{CO}_{3}\right)=0,025 \mathrm{~mol} \cdot \mathrm{dm}^{-3}$, és $\mathrm{pH}=10,0$.

Azt tapasztaltam, hogy $5 \mathrm{~cm}^{3} \cdot \mathrm{h}^{-1}$ térfogat-áramlási sebesség esetén romboéderes és gömbszerú struktúrákat is tartalmaz a minta. A csapadékmintázat különbözô területein azonban eltérô arányban fordulnak elő (lásd a 6.4. táblázatot). A betáplálás helyétôl $(x)$ mért $7 \mathrm{~cm}$ távolságban már szinte kizárólag csak romboéder alakú részecskék alakulnak ki. A százalékos értékeket 30 felvétel alapján számítottam, amelyen átlagosan kb. 40 részecske található.

6.4. táblázat. $\mathrm{Az} 5 \mathrm{~cm}^{3} \cdot \mathrm{h}^{-1}$ térfogat-áramlási sebességen kialakult kalcium-karbonát csapadék esetén a kalcium-klorid-oldat betáplálásának helyétől mért adott távolságban $(x)$ lévő romboéder és gömb alakú részecskék aránya.

\begin{tabular}{ccc}
\hline \hline$x$ & gömb (\%) & romboéder (\%) \\
\hline $1 \mathrm{~cm}$ & 36 & 64 \\
$3 \mathrm{~cm}$ & 26 & 74 \\
$7 \mathrm{~cm}$ & 2 & 98 \\
\hline \hline
\end{tabular}

Áramlásvezérelt körülmények között $20 \mathrm{~cm}^{3} \cdot \mathrm{h}^{-1}$ térfogat-áramlási sebességnél nem találtam gömbszerú részecskéket, csak romboéderek, valamint szórványosan téglatestek alakultak ki (6.7. ábra). A mintát optikai mikroszkóp segítségével is tanulmányoztuk, melynek előnye, hogy jóval nagyobb területet tudunk tüzetesen átvizsgálni, mint a pásztázó elektronmikroszkópiás minták esetén. Pásztázó elektronmikroszkóppal is azt tapasztaltam, hogy 
kizárólag romboéderes részecskék alakultak ki a mintában, amennyiben $20 \mathrm{~cm}^{3} \cdot \mathrm{h}^{-1}$ vagy nagyobb térfogat-áramlási sebességet alkalmaztam. A csapadékmintázat különböző területein elhelyezkedő részecskék azonos alakúak (6.7. A és B ábra).
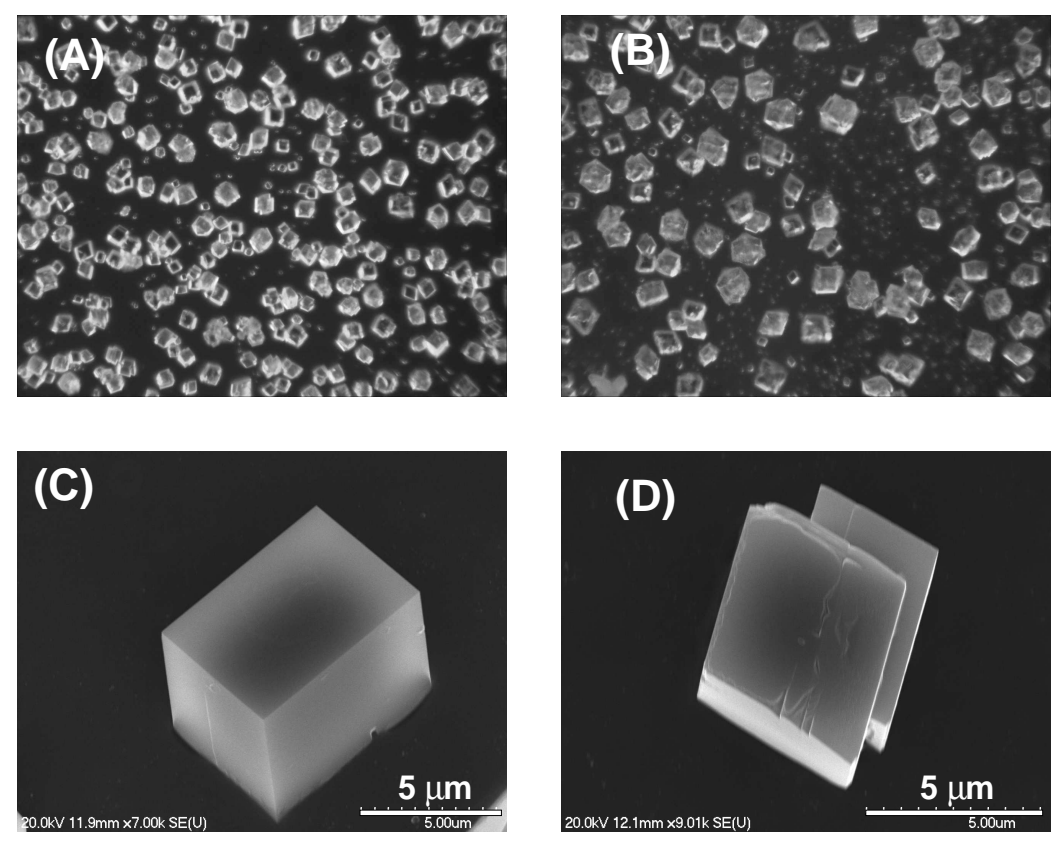

6.7. ábra. Az áramlásvezérelt $\left(q_{\mathrm{V}}=20 \mathrm{~cm}^{3} \cdot \mathrm{h}^{-1}\right)$ kalcium-karbonát csapadék optikai mikroszkópiás (képszélesség: 486 $\mu \mathrm{m}$ ) (A) és (B) valamint pásztázó elektronmikroszkópiás (C) és (D) felvételei. A kísérleti paraméterek: $c\left(\mathrm{CaCl}_{2}\right)=4,0 \mathrm{~mol} \cdot \mathrm{dm}^{-3}, c\left(\mathrm{Na}_{2} \mathrm{CO}_{3}\right)=0,025$ $\mathrm{mol} \cdot \mathrm{dm}^{-3}$, és $\mathrm{pH}=10,0$.

A 10 és $15 \mathrm{~cm}^{3} \cdot \mathrm{h}^{-1}$ térfogat-áramlási sebesség esetén azonban a mikroszerkezetben véletlenszerúen változott a romboéderek és gömbök aránya. Az optikai mikroszkópiás felvételek készítése során megállapítottuk, hogy a kalcium-klorid-oldat betáplálásának helyétől távolodva egyre nô a részecskék mérete, ezért ezt a méreteloszlást is tanulmányoztuk. Az ábrák kétdimenziósak, így a részecske leghosszabb $(a)$, és az arra merôleges $(b)$ tengelyét mértem meg, majd a képpontegységben megkapott adatot $\mu \mathrm{m}$ mértékegységbe átszámítottam. A részecske leghosszabb $(a)$, és az arra merôleges $(b)$ tengelyét egymással elosztottam egymással $(a / b)$, és a kapott értékeket a részecskeszám függvényében ábrázoltam a 6.8. ábrán. 


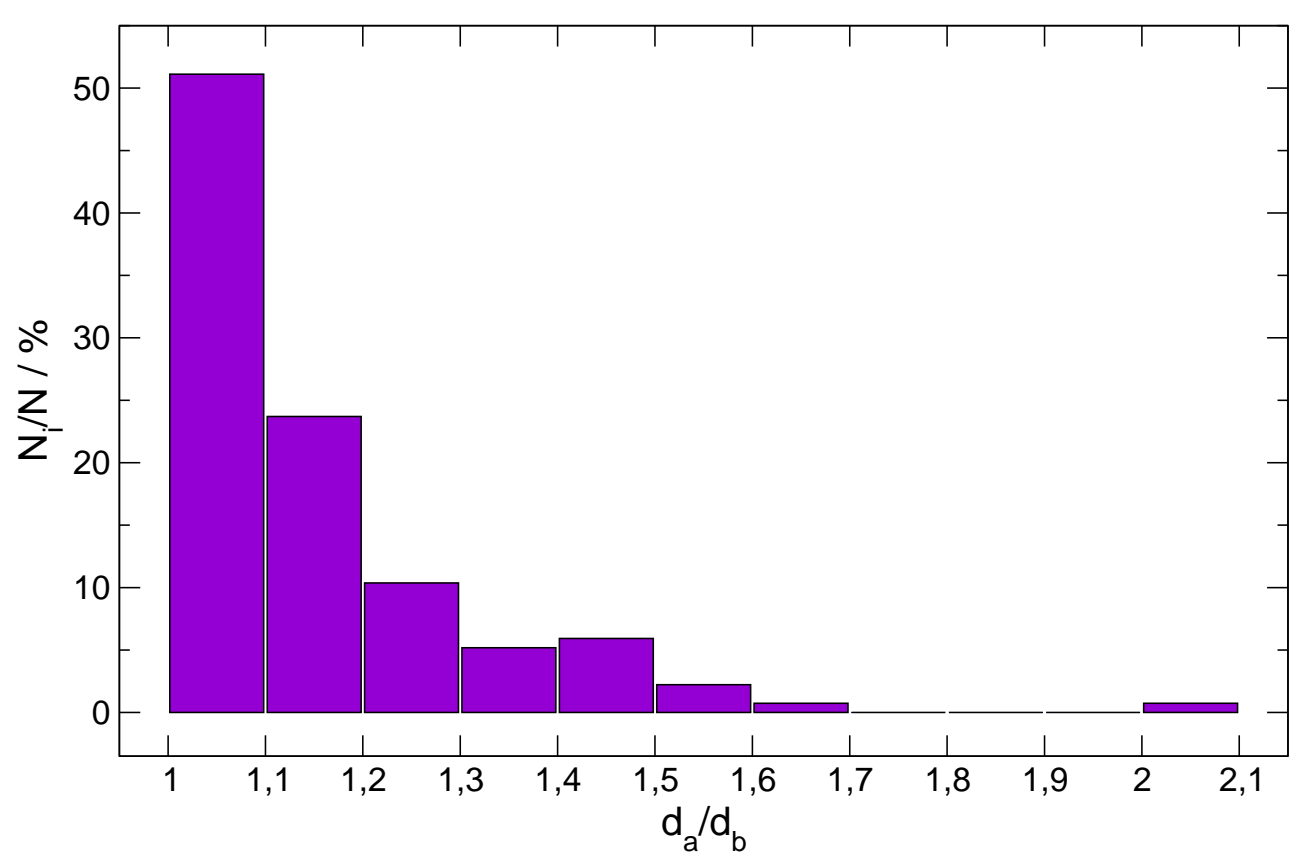

6.8. ábra. A romboéder alakú részecske leghosszabb ( $a$ ), és az arra merőleges $(b)$ tengelyéhez tartozó hosszúság hányadosa a részecskék százalékos előfordulásának függvényében.

Ebből az oszlopdiagramból az látható, hogy a részecskék nagy része romboéder alakúnak tekinthetô, és a méreteloszlást elegendő az $a$-tengelyhez tartozó adatokból kiszámítani.

A 6.9. ábrán az $5 \mathrm{~cm}^{3} \cdot \mathrm{h}^{-1}$ térfogat-áramlási sebességgel történô kalcium-klorid-oldat betáplálásának helyétôl mért távolságban ((A) $x=1 \mathrm{~cm},(\mathrm{~B}) x=3 \mathrm{~cm},(\mathrm{C}) x=7 \mathrm{~cm})$ lévő romboéder alakú részecskék eloszlásdiagramja látható. Az ábrán a maximum $6 \mu \mathrm{m}, 10$ $\mu \mathrm{m}$, majd $17 \mu \mathrm{m}$-nél jelenik meg. A betáplálás helyétől számított $1 \mathrm{~cm}$-es távolságban (6.9. A ábra) közel szimmetrikus eloszlás helyett $7 \mathrm{~cm}$ távolságban (6.9. C ábra) már egy jóval laposabb eloszlást detektáltam, azaz a részecskék mérete kevésbé egységes, és nagyobb méretú részecskék is kialakulhatnak. 

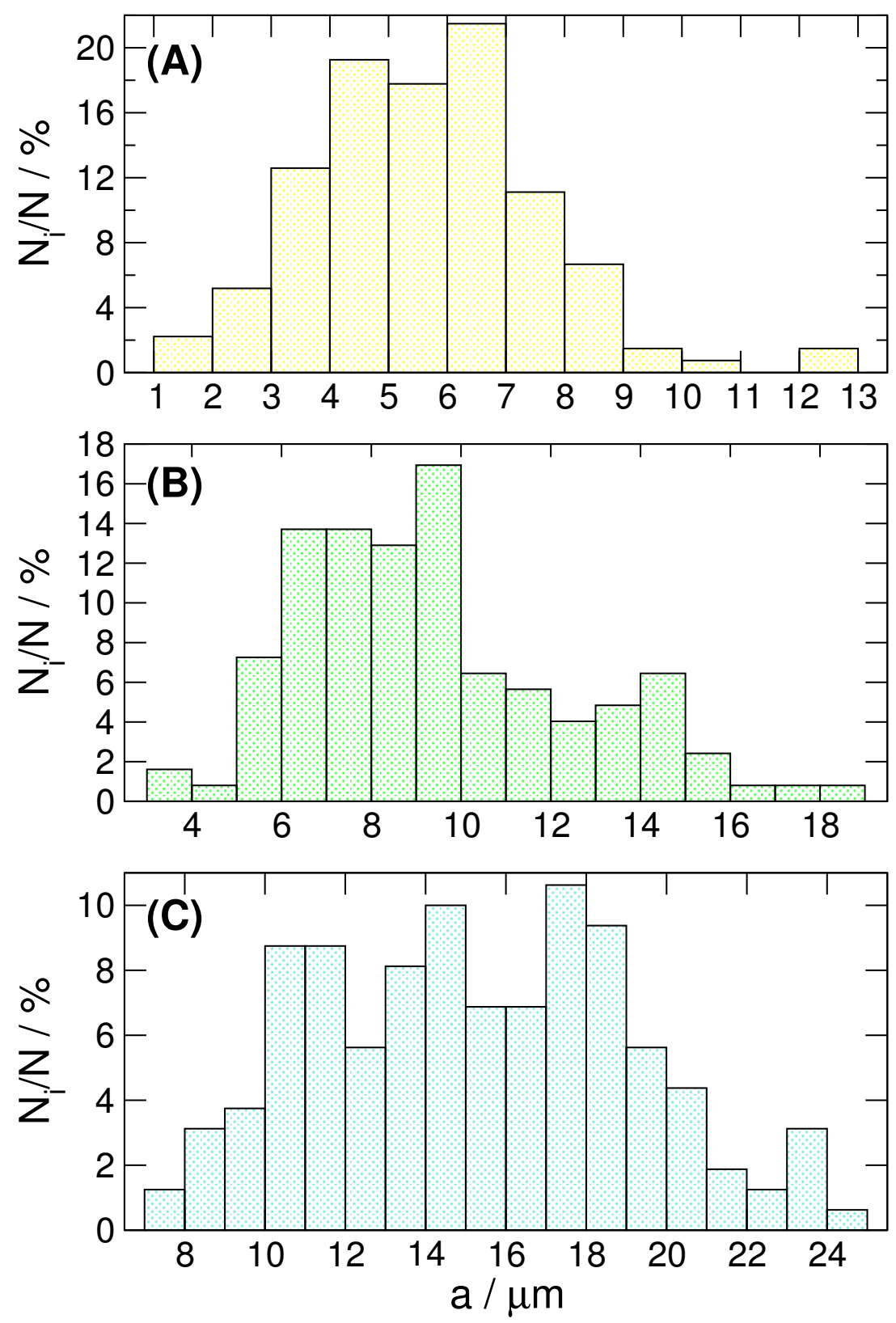

6.9. ábra. Eloszlásdiagramok a romboéderek esetén az $5 \mathrm{~cm}^{3} \cdot \mathrm{h}^{-1}$ térfogat-áramlási sebességnél kialakult kalcium-karbonát csapadékmintázatban. A betáplálás helyétôl mért távolságok: $x=1 \mathrm{~cm}(\mathrm{~A}), x=3 \mathrm{~cm}(\mathrm{~B})$, és $x=7 \mathrm{~cm}(\mathrm{C})$.

A gömbök vizsgálatakor a tengelyek hányadosát tekintve szintén elég az $a$-tengelyhez tartozó adatokkal jellemezni a méreteloszlást. A 6.10. ábrán jól látható, hogy távolodva a betáplálási helytôl, a gömbök mérete is nő. Ezzel ellentétben, 7 cm távolságban már annyira kevés gömb alakú részecske képződött, hogy nem állt rendelkezésre elegendő adat egy eloszlásdiagram készítéséhez. A méreteloszlásokon továbbá az is megfigyelhetô, hogy a gömbök mérete egységesebb, kisebb mérettartományba esnek. Míg $1 \mathrm{~cm}$ távolságon a romboéderek $\sim 23 \%$-a kb. $6 \mu \mathrm{m}$, a gömbök több mint 30\%-a $4 \mu \mathrm{m}$. Az eloszlás jellemző paramétereit a 6.5. táblázatban összegeztem. 
6.5. táblázat. Az $5 \mathrm{~cm}^{3} \cdot \mathrm{h}^{-1}$ áramlási sebességnél kialakult részecskék méreteloszlásának jellemzó paraméterei: az átlag, a szórás és a maximum.

\begin{tabular}{ccccccc}
\hline \hline távolság & \multicolumn{3}{c}{ romboéderek $(\mu \mathrm{m})$} & \multicolumn{3}{c}{ gömbök $(\mu \mathrm{m})$} \\
$x(\mathrm{~cm})$ & átlag & szórás & maximum & átlag & szórás & maximum \\
\hline $1-1,5$ & 5,65 & 1,99 & 12,64 & 4,29 & 1,69 & 8,39 \\
$3-3,5$ & 9,39 & 3,07 & 18,29 & 5,27 & 2,55 & 13,48 \\
$7-7,5$ & 15,22 & 3,95 & 24,46 & - & - & - \\
\hline \hline
\end{tabular}

A betáplálás helyétől számítva szintén nő a romboéder alakú részecskék mérete $20 \mathrm{~cm}^{3} \cdot \mathrm{h}^{-1}$ térfogat-áramlási sebesség esetén, de sok apró romboéder is kialakul, hiszen túltelített az oldat, és jelentős mértékû a gócképződés. Így kevésbé észlelhető az áramlás részecskeméretet növelố hatása, mint az $5 \mathrm{~cm}^{3} \cdot \mathrm{h}^{-1}$ térfogat-áramlási sebességgel elvégzett kísérlet esetén.

A jól kevert rendszerben a gömbök és a romboéderek aránya véletlenszerúen változik az 50-50\% közelében. A gömbök mérete átlagosan 8,9 $\mu \mathrm{m}( \pm 3,0 \mu \mathrm{m})$ míg a romboéderek mérete kb. 11,6 $\mu \mathrm{m}( \pm 2,7 \mu \mathrm{m})$.
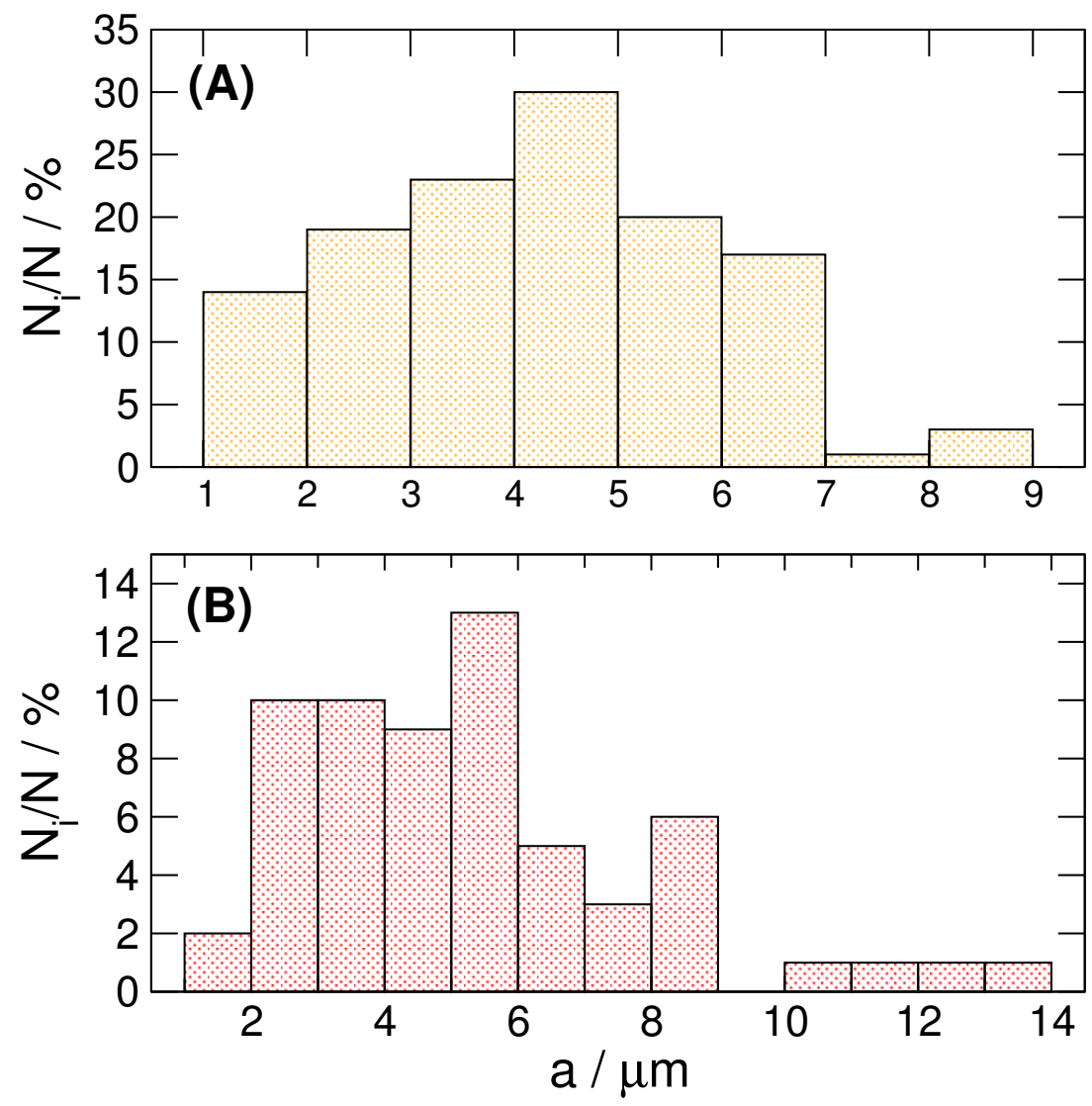

6.10. ábra. A gömbök méretének eloszlásdiagramjai az $5 \mathrm{~cm}^{3} \cdot \mathrm{h}^{-1}$ térfogat-áramlási sebességnél kialakult kalcium-karbonát csapadékban. A betáplálás helyétôl mért távolságok: $x=$ $1 \mathrm{~cm}(\mathrm{~A}), x=3 \mathrm{~cm} \mathrm{(B).}$ 


\subsection{Raman-mikroszkópiás vizsgálatok}

A pásztázó elektronmikroszkóp segítségével már megállapítottuk, hogy két különbözô alakú részecske található a mintában. Mivel különbözik a kristályszerkezetük, rezgési színképek segítségével azonosíthatóak a különbözô polimorf módosulatok (6.6. ábra). A kalciumkarbonát különböző formáinak (aragonit, kalcit, vaterit) Raman-színképében található legintenzívebb sávok az 1084, az 1086 és a 1089 cm ${ }^{-1}$ hullámszám értékhez tartoznak.

6.6. táblázat. A kalcium-karbonát csapadékok Raman spektrumában lévő jellemző sávmaximumok irodalmi értékei csökkenő intenzitásnak megfelelő sorrendben [98].

\begin{tabular}{ccccc}
\hline \hline \multicolumn{2}{c}{ referencia spektrumok $\left(\mathrm{cm}^{-1}\right)$} & \multicolumn{2}{c}{ mért spektrumok $\left(\mathrm{cm}^{-1}\right)$} \\
aragonit & kalcit & vaterit & romboéder & gömb \\
\hline 1084 & 1086 & 1089 & 1086 & 1090 \\
703 & 712 & 713 & 712 & 1074 \\
1460 & 1436 & 752 & 1436 & 751 \\
& 1749 & 1750 & 1749 & 1750 \\
& & 1437 & & 1443 \\
\hline \hline
\end{tabular}

Elsôként a $20 \mathrm{~cm}^{3} \cdot \mathrm{h}^{-1}$ térfogat-áramlási sebességú áramlásvezérelt minta külsô körének és a jól kevert mintának a spektrumát vettük fel. Az illesztés során megállapítottuk, hogy a két rendszerben a legintenzívebb sáv nem azonos hullámszámértéknél jelent meg, ezért a további kísérletek során üveglapon elkészített mintát vizsgáltam. Megfelelő nagyítással $(40 \times)$ képfelvételt készítettem a különbözô részecskékről, és felvettük a 6.11. ábrán piros + jellel jelölt egyedi részecskék spektrumát is. Megállapítottuk, hogy a romboéder alakú részecske kalcit [129], a gömb alakú részecske pedig a polikristályos vaterit [130] módosulatból áll (6.12. ábra).
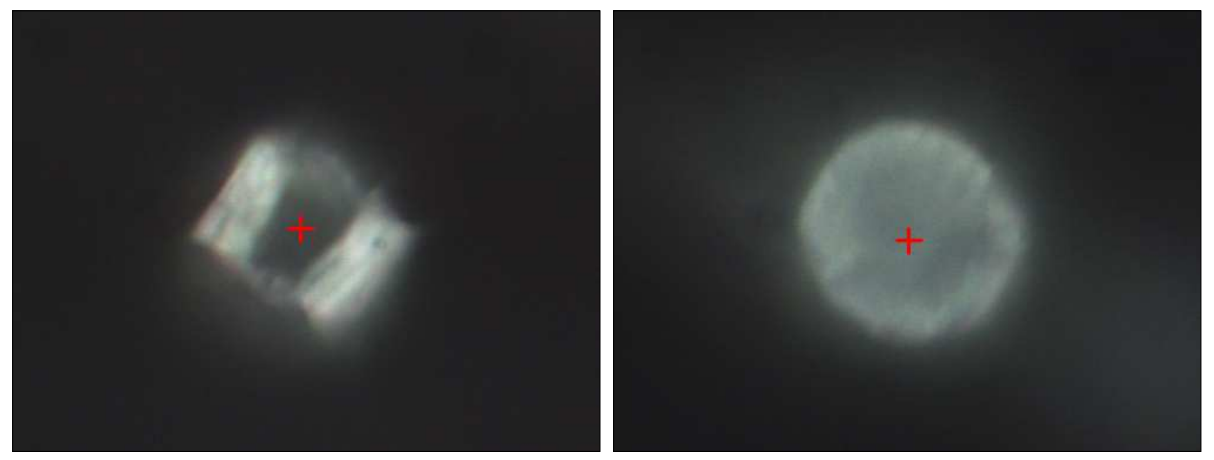

6.11. ábra. A kalcium-karbonát áramlásvezérelt körülmények között képződött romboéder és gömb alakú formájának Raman-mikroszkóppal készített felvétele $40 \times$ nagyításban. A kísérleti paraméterek: $c\left(\mathrm{CaCl}_{2}\right)=4,0 \mathrm{~mol} \cdot \mathrm{dm}^{-3}, c\left(\mathrm{Na}_{2} \mathrm{CO}_{3}\right)=0,025 \mathrm{~mol} \cdot \mathrm{dm}^{-3}, \mathrm{pH}=10,0$ és $q_{\mathrm{V}}=5 \mathrm{~cm}^{3} \cdot \mathrm{h}^{-1}$. 
A gömb alakú részecske színképére Gauss-Lorentz-görbéket illesztettem, és az általunk referenciaként használt adatokon kívül még egy, $1074 \mathrm{~cm}^{-1}$-nél megjelenő sávot találtam (6.6. táblázat). Azt várnánk, hogy a karbonátion szimmetrikus $\mathrm{C}-\mathrm{O}$ rezgése nem degenerált, de ez az $1089 \mathrm{~cm}^{-1}$-nél lévő rezgési mód felhasad egy dublettre, ami azt jelenti, hogy kétféle szimmetrikus nyújtórezgés történik (6.12. ábra). Ez bizonyítja azt is, hogy a vaterit elemi cellájában kétféle módon is elhelyezkedhet a karbonátion [131].

Ezekkel a kísérletekkel azt támasztottuk alá, hogy áramlásvezérelt körülmények között a kalcium-karbonátból tisztán kalcit módosulat alakul ki, ha $20 \mathrm{~cm}^{3} \cdot \mathrm{h}^{-1}$ vagy annál nagyobb térfogat-áramlási sebességet alkalmazunk.

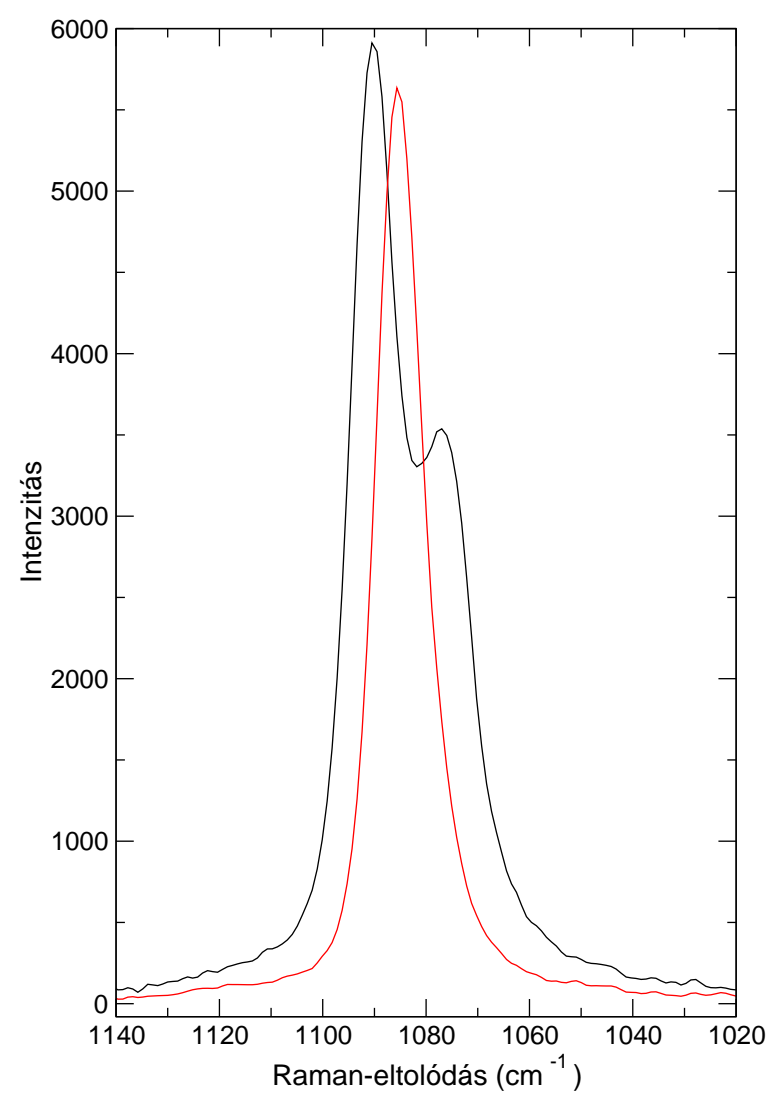

6.12. ábra. A kalcit (romboéder, $1086 \mathrm{~cm}^{-1}$ ) és a vaterit $\left(1090\right.$ és $1074 \mathrm{~cm}^{-1}$ ) Raman-spektrumában mért legintenzívebb sávok. A kísérleti paraméterek: $c\left(\mathrm{CaCl}_{2}\right)=4,0 \mathrm{~mol} \cdot \mathrm{dm}^{-3}, c\left(\mathrm{Na}_{2} \mathrm{CO}_{3}\right)=0,025 \mathrm{~mol} \cdot \mathrm{dm}^{-3}, \mathrm{pH}=10,0$, és $q_{\mathrm{V}}=5 \mathrm{~cm}^{3} \cdot \mathrm{h}^{-1}$. 


\section{7. fejezet}

\section{Kalcium-oxalát-kalcium-karbonát mintázatok}

\subsection{A koncentrációeloszlás számítása}

A vegyes csapadékok mennyiségének meghatározásakor olyan egyensúlyi számolásokat végeztem, amelyek során figyelembe vettem a kalcium-oxalát ((5.1) egyenlet), a kalcium-karbonát ((6.1) egyenlet), és a kalcium-hidroxid ((5.2) egyenlet) csapadék leválását, valamint a komplexképződési és protonálódási egyensúlyokat is. A számítást a korábbiakban bemutatott módon hajtottam végre három futtatás során, melyeket $\mathrm{pH}=0,00,5,14$ és 11,11-tôl indítottam. Az elsőben a kalcium-oxalát csapadék leválásával számoltam, míg a kalciumkarbonátot és a kalcium-hidroxidot olyan formában vettem figyelembe, hogy eléri-e az oldhatósági szorzatot a komponenseik koncentrációjának a szorzata. Ezt követően elsôként 5,14-nél a kalcium-karbonát jelent meg, majd a harmadik számításban a kalcium-hidroxid is szerepelt, melyet 11,12-tôl indítottam. Ebben a tartományban a múveletek megkönnyítéséhez három egyszerúsítést vezettem be:

$$
\begin{aligned}
{\left[\mathrm{Ca}^{2+}\right] } & =K_{\mathrm{SP}}\left(\mathrm{Ca}(\mathrm{OH})_{2}\right) \cdot \frac{\left[\mathrm{H}^{+}\right]^{2}}{\mathrm{~K}_{\mathrm{V}}^{2}} \\
{\left[\mathrm{COO}_{2}^{2-}\right] } & =\frac{K_{\mathrm{SP}}\left(\mathrm{Ca}(\mathrm{COO})_{2}\right)}{\left[\mathrm{Ca}^{2+}\right]} \\
{\left[\mathrm{HCO}_{3}^{-}\right] } & =\frac{K_{\mathrm{SP}}\left(\mathrm{CaCO}_{3}\right) \cdot\left[\mathrm{H}^{+}\right] \cdot \mathrm{K}_{\mathrm{H}_{1}}}{\left[\mathrm{Ca}^{2+}\right]}
\end{aligned}
$$

A paraméterek megadásakor $0,025 \mathrm{~mol} \cdot \mathrm{dm}^{-3}$ nátrium-karbonát, $0,025 \mathrm{~mol} \cdot \mathrm{dm}^{-3}$ nátrium-oxalát, és 4,0 $\mathrm{mol} \cdot \mathrm{dm}^{-3}$ kalcium-klorid-oldatot adtam meg, a számítást a 0-14 pHtartományon végeztem, és $10^{-14}$ relatív hibát állítottam be. Az eredmények azt mutatták, hogy a csapadékok és a komplexek közel azonos mennyiségben vannak jelen a tisztán kalcium-oxalátot és kalcium-karbonátot tartalmazó számításokkal. A 7.1. ábrán a komplexek nagy száma miatt csupán a csapadékokat ábrázoltam. Látható, hogy a legkevesebb 
mennyiségben a kalcium-karbonát válik le, a legtöbb pedig a kalcium-hidroxid csapadék. $\mathrm{Az}$ is látható, ha a kísérletek során a nátrium-oxalátot és -karbonátot tartalmazó oldat kémhatását $\mathrm{pH}=10$-re állítom, akkor továbbra is el tudom kerülni a kalcium-hidroxid csapadék leválását.

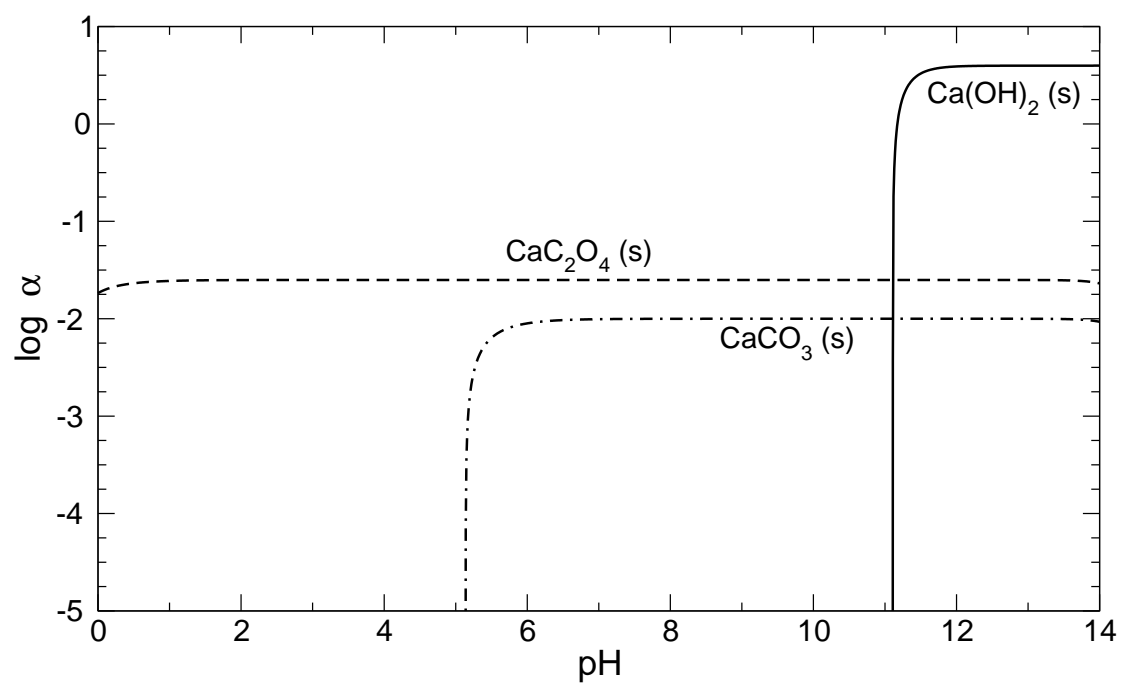

7.1. ábra. Az egyensúlyi számítások végeredménye: kalcium-oxalát, kalcium-karbonát, és kalcium-hidroxid csapadékok aránya a $\mathrm{pH}$ fügvényében $0,025 \mathrm{~mol} \cdot \mathrm{dm}^{-3}$ nátrium-karbonát, nátrium-oxalát, és $4,0 \mathrm{~mol} \cdot \mathrm{dm}^{-3} \mathrm{kalcium}-\mathrm{klorid}$-oldat esetén. 


\subsection{Az oldatok koncentrációinak változtatása}

Elsôként nátrium-oxalát és nátrium-karbonát oldatok 1:1 anyagmennyiség-arányú elegyét készítettem el, melyben az anionok összkoncentrációja $0,05 \mathrm{~mol} \cdot \mathrm{dm}^{-3}$ volt. Ebbe áramoltattam $20 \mathrm{~cm}^{3} \cdot \mathrm{h}^{-1}$ térfogat-áramlási sebességgel 4,0 $\mathrm{mol} \cdot \mathrm{dm}^{-3}$ kalcium-klorid-oldatot. Ekkor a 7.2. ábrán látható mintázat fejlődését követhettem nyomon.
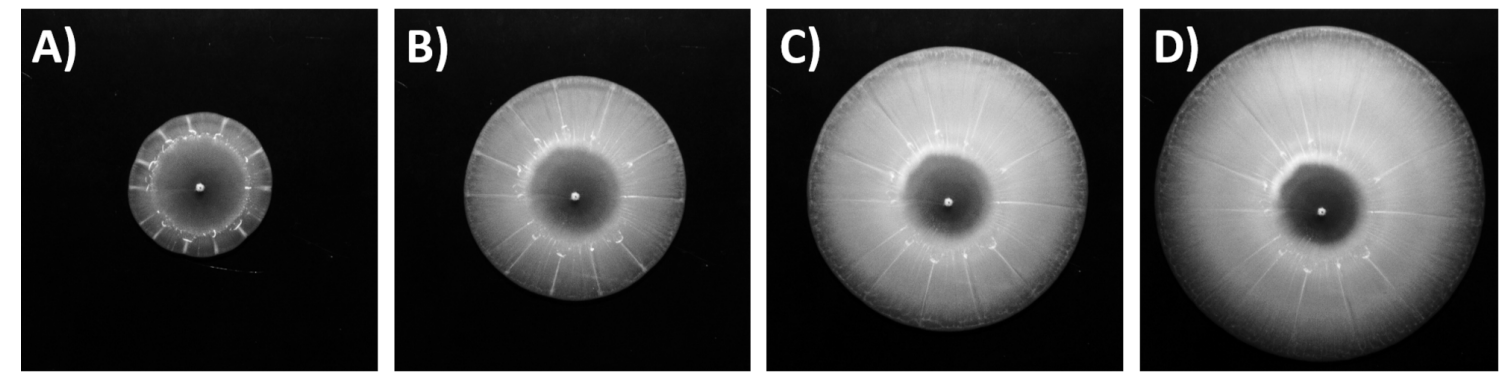

7.2. ábra. A csapadékmintázat kialakulása $0,025 \mathrm{~mol} \cdot \mathrm{dm}^{-3}$ koncentrációjú nátrium-oxalát és nátrium-karbonát-oldat alkalmazása mellett a 2., 4., 6., és 8. percben. A kísérleti paraméterek: $c\left(\mathrm{CaCl}_{2}\right)=4,0 \mathrm{~mol} \cdot \mathrm{dm}^{-3}, c\left(\mathrm{Na}_{2} \mathrm{C}_{2} \mathrm{O}_{4}\right)=c\left(\mathrm{Na}_{2} \mathrm{CO}_{3}\right)=0,05 \mathrm{~mol} \cdot \mathrm{dm}^{-3}$, $q \mathrm{~V}=20 \mathrm{~cm}^{3} \cdot \mathrm{h}^{-1}$, és $\mathrm{pH}=10,0$.

A kísérlet indításakor leválik egy masszív csapadékhártya, amely nem engedi a csapadék további terjedését. További kalcium-klorid-oldat áramoltatására ez a membrán elszakad, és a töréspontokon intenzív kiáramlás indul meg. Ennek köszönhető, hogy 12 helyen élesen elkülönülő szálak alakultak ki. Az ilyen nagy anionkoncentráció alkalmazásának hátránya, hogy túl sok csapadék keletkezik, továbbá, hogy nem elegendően nagy a sưrúségkülönbség a szálas mintázat létrehozásához.

Emiatt olyan oldatot készítettem, amelyben a nátrium-karbonát és a nátrium-oxalát-oldatok összkoncentrációja $0,025 \mathrm{~mol} \cdot \mathrm{dm}^{-3}$. Ezáltal kisebb mennyiségú csapadék képződik, és szálasabb, áramlásvezérelt mintázat alakul ki. Ezen belül három eltérő koncentrációarányt választottam: nátrium-oxalát:nátrium-karbonát $=1: 1,1: 2$, valamint 2:1. A kiértékelés során meghatároztam a mintázatra jellemző paramétereket (a belső $\left(r_{\mathrm{b}}\right)$ és a külsô $\left(r_{\mathrm{k}}\right)$ sugár, a szálak száma $(N)$, és a gravitációs áram átlagos magassága $(\bar{h})$, melyeket a 7.1. táblázatban összegeztem.

A külső kör sugarának számadatai arról tanúskodnak, hogy a nagy karbonátiontartalom esetén a masszív csapadékréteg kialakulása meggátolja a folyadék normál ütemú terjedését, ezáltal kisebb méretú mintázatok keletkeznek. A legnagyobb csapadékkorong pedig a nátrium-oxalátot feleslegben tartalmazó oldatok esetén jött létre, és ez tartalmazta a legtöbb szálat is, melyet a 7.3. ábra jól szemléltet. 
7.1. táblázat. A vegyes csapadékmintázatot leíró mennyiségek: a belső $\left(r_{\mathrm{b}}\right)$ és a külső $\left(r_{\mathrm{k}}\right)$ sugár, a szálak száma $(N)$, és a gravitációs áram átlagos magassága $(\bar{h})$.

\begin{tabular}{cccccccc}
\hline \hline \multicolumn{2}{c}{ koncentrációk } & arány & \multicolumn{4}{c}{$\Delta \rho$} & \multicolumn{3}{c}{ mintázat jellemzó paraméterei } \\
$c\left(\mathrm{Na}_{2} \mathrm{C}_{2} \mathrm{O}_{4}\right)$ & $c\left(\mathrm{Na}_{2} \mathrm{CO}_{3}\right)$ & $c\left(\mathrm{Na}_{2} \mathrm{C}_{2} \mathrm{O}_{4}\right) /$ & $\left(\mathrm{g} \cdot \mathrm{cm}^{-3}\right)$ & $r_{\mathrm{b}}$ & $r_{\mathrm{k}}$ & $N$ & $\bar{h}$ \\
$\left(\mathrm{~mol} \cdot \mathrm{dm}^{-3}\right)$ & $\left(\mathrm{mol} \cdot \mathrm{dm}^{-3}\right)$ & $c\left(\mathrm{Na}_{2} \mathrm{CO}_{3}\right)$ & & $(\mathrm{mm})$ & $(\mathrm{mm})$ & $(\mathrm{db})$ & $(\mathrm{mm})$ \\
\hline 0,0125 & 0,0125 & $1: 1$ & 0,3311 & 30 & 70 & - & 0,021 \\
0,0167 & 0,0083 & $2: 1$ & 0,3310 & 34 & 79 & 100 & 0,017 \\
0,0083 & 0,0167 & $1: 2$ & 0,3311 & - & 50 & - & 0,043 \\
\hline \hline
\end{tabular}
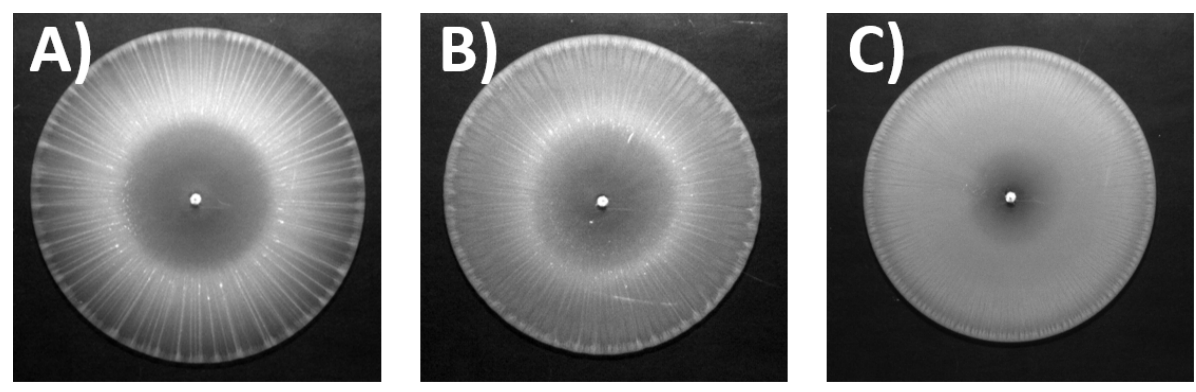

7.3. ábra. A kalcium-oxalát-kalcium-karbonát vegyes csapadékmintázat $0,025 \mathrm{~mol} \cdot \mathrm{dm}^{-3}$ összes anionkoncentrációnál. A koncentrációarány $\left(c\left(\mathrm{Na}_{2} \mathrm{C}_{2} \mathrm{O}_{4}\right): c\left(\mathrm{Na}_{2} \mathrm{CO}_{3}\right)\right)$ az egyes esetekben: 2:1 (A), 1:1 (B), és 1:2 (C). A kísérleti paraméterek: $c\left(\mathrm{CaCl}_{2}\right)=4,0 \mathrm{~mol} \cdot \mathrm{dm}^{-3}$, $q_{\mathrm{V}}=20 \mathrm{~cm}^{3} \cdot \mathrm{h}^{-1}$, és $\mathrm{pH}=10,0$.

Az oxalátionban gazdagabb csapadék a legszálasabb, amely annak köszönhetô, hogy ebben az esetben megvan a megfelelő sûrűségkülönbség, és a megfelelő mennyiségû csapadék is, hiszen ha alaposan szemügyre vesszük a 7.1. ábrát, akkor látható, hogy kalciumkarbonátból kevesebb csapadék válik le, mint a kalcium-oxalátból, ami miatt jobban látható a csapadék felhalmozódása a szálak mentén.

Meghatároztam a csapadékok területének az időbeli növekedését is, mely a 7.4. ábrán látható. A pontokkal a kísérleti adatokat, míg a folytonos vonallal az illesztést szemléltetem. Ugyan az ábra az 1:1 arányú csapadék méretének időfüggését szemlélteti, a csapadékkör sugara mindhárom esetben négyzetgyökös összefüggést mutat az eltelt idôvel. A (4.8) egyenlet illesztésének paramétereit a 7.2. táblázatban összegeztem. Látható, hogy az állandók $\left(a_{0}, a_{1}\right.$, és $a_{2}$ ) eltérőek. 
7.2. táblázat. A csapadékmintázatok idôbeli változására illesztett paraméterek.

\begin{tabular}{ccccccc}
\hline \hline $\begin{array}{c}c\left(\mathrm{CaCl}_{2}\right) \\
\left(\mathrm{mol} \cdot \mathrm{dm}^{-3}\right)\end{array}$ & $\begin{array}{c}c\left(\mathrm{Na}_{2} \mathrm{C}_{2} \mathrm{O}_{4}\right) \\
\left(\mathrm{mol} \cdot \mathrm{dm}^{-3}\right)\end{array}$ & $\begin{array}{c}c\left(\mathrm{Na}_{2} \mathrm{CO}_{3}\right) \\
\left(\mathrm{mol} \cdot \mathrm{dm}^{-3}\right)\end{array}$ & arány & $\begin{array}{c}a_{0} \\
\mathrm{~cm} \mathrm{~s}^{-1}\end{array}$ & $\begin{array}{c}a_{1} \\
\mathrm{~s}\end{array}$ & $\begin{array}{c}a_{2} \\
\mathrm{~cm}\end{array}$ \\
\hline 4 & 0,0125 & 0,0125 & $1: 1$ & $55,0(0,53)$ & $0,7(0,05)$ & $-40,3(1,77)$ \\
4 & 0,0167 & 0,0083 & $2: 1$ & $53,4(0,19)$ & $0,6(0,02)$ & $-34,0(0,66)$ \\
4 & 0,0083 & 0,0167 & $1: 2$ & $53,1(0,41)$ & $0,9(0,06)$ & $-45,2(1,64)$ \\
\hline \hline
\end{tabular}

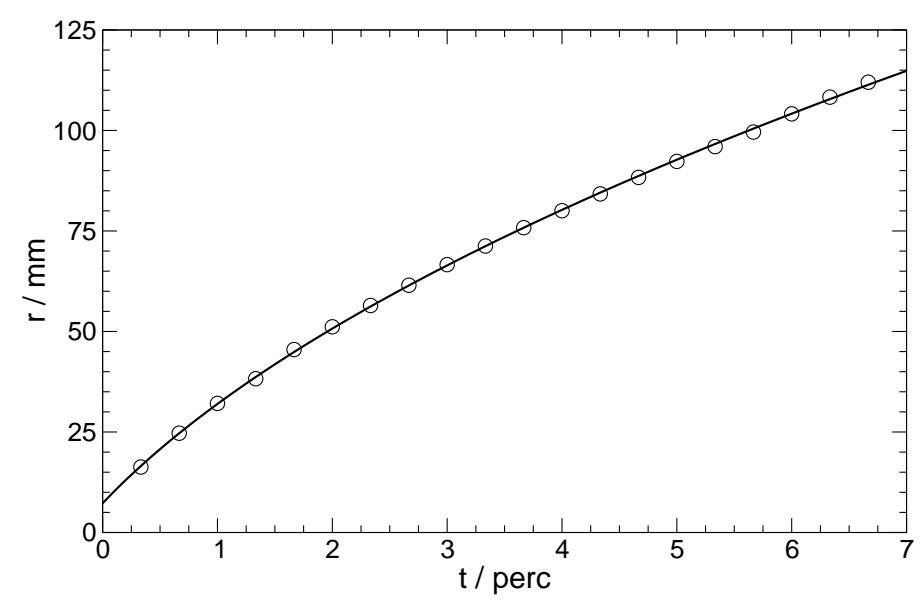

7.4. ábra. A kalcium-karbonát csapadékmintázat sugarának növekedése. A pontok a kísérleti adatokat, míg a folytonos vonal az illesztett függvényt jelöli. A kísérleti paraméterek: $c\left(\mathrm{Na}_{2} \mathrm{C}_{2} \mathrm{O}_{4}\right)=c\left(\mathrm{Na}_{2} \mathrm{CO}_{3}\right)=0,0125 \mathrm{~mol} \cdot \mathrm{dm}^{-3}, c\left(\mathrm{CaCl}_{2}\right)=4,0 \mathrm{~mol} \cdot \mathrm{dm}^{-3}$, $q_{\mathrm{V}}=20 \mathrm{~cm}^{3} \cdot \mathrm{h}^{-1}$, és $\mathrm{pH}=10,0$.

A módszer pontosságát úgy határoztam meg, hogy visszaszámoltam a kapott $a_{0}$ értékek felhasználásával a gravitációs áram átlagos magasságát. Ezek az értékek $\left(\bar{h}_{2}\right)$ nagyságrendileg jó egyezést mutatnak (7.3. táblázat), ráadásul az eltérések a képpontokban mért bizonytalanságon belül lévő értékek. Ezek alapján, a módszer becslésre alkalmasnak bizonyult.

7.3. táblázat. A gravitációs áram átlagos magasságának megadása kétféle módon.

\begin{tabular}{ccccc}
\hline \hline $\begin{array}{c}c\left(\mathrm{Na}_{2} \mathrm{C}_{2} \mathrm{O}_{4}\right) \\
\left(\mathrm{mol} \cdot \mathrm{dm}^{-3}\right)\end{array}$ & $\begin{array}{c}c\left(\mathrm{Na}_{2} \mathrm{CO}_{3}\right) \\
\left(\mathrm{mol} \cdot \mathrm{dm}^{-3}\right)\end{array}$ & $\begin{array}{c}\text { koncentráció- } \\
\text { arány }\end{array}$ & $\begin{array}{c}\bar{h}_{1} \\
(\mathrm{~mm})\end{array}$ & $\begin{array}{c}\bar{h}_{2} \\
(\mathrm{~mm})\end{array}$ \\
\hline 0,0125 & 0,0125 & $1: 1$ & 0,021 & 0,026 \\
0,0167 & 0,0083 & $2: 1$ & 0,017 & 0,024 \\
0,0083 & 0,0167 & $1: 2$ & 0,043 & 0,033 \\
\hline \hline
\end{tabular}




\subsection{Pásztázó elektronmikroszkópiás és Raman-mikroszkó- piás analízis}

A kalcium-oxalát csapadék részecskéi olyan kis méretúek, hogy az optikai mikroszkópiás felvételek nem szolgáltatnak megfelelő képeket a kristályokról. Így, korábbi tapasztalatainkra alapozva, pásztázó elektronmikroszkópiás felvételeket készítettem. A felvételeken felismertem a kalcium karbonát jellegzetes romboéderes kalcit formáját, a kalcium-oxalátmonohidrátra jellemző rózsaszerú, összetett struktúrákat, oktaéderes kalcium-oxalát-dihidrátot, valamint egy új, $x$ alakú részecskét is. A vaterit polikristályos formáját azonban egyik felvételen sem találtam. Az ábrákat tüzetesebben megvizsgálva egy érdekes következtetésre jutunk: a rózsa alakú részecske mégsem teljesen ugyanaz a rózsa. A kalcium-oxalátmonohidrát „szirmai” lekerekítettebbek és legtöbbször háromszögú csúcsban érnek véget, míg a vegyes rendszerben inkább téglatestekből épül fel a virág.
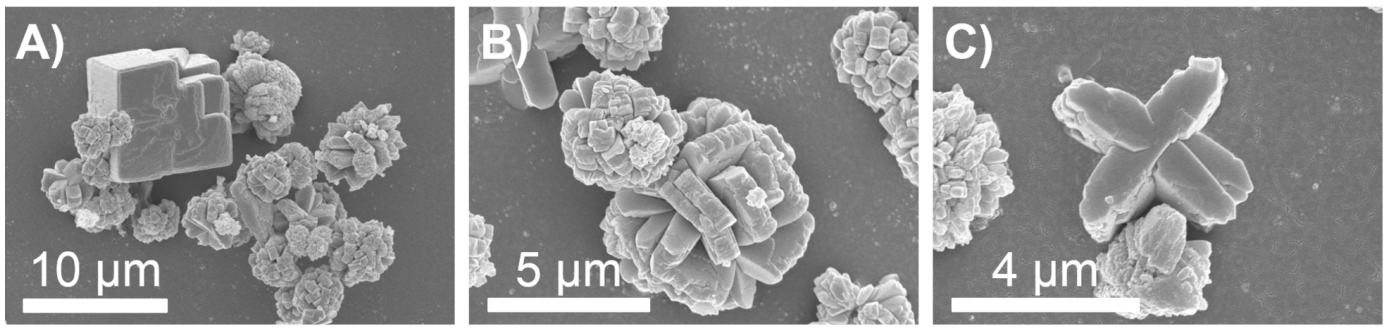

7.5. ábra. Pásztázó elektronmikroszkóp felvételei az 1:1 arányú áramlásvezérelt csapadékmintázatból. Romboéderes kalcit kristály (A), tipikus rózsára emlékeztetô, kalcium-oxalátmonohidrátot biztosan tartalmazó gömb formájú, összetett struktúrájú részecskék (B), és az x alakot öltött kristály (C).

Hogy megállapíthassuk a részecskék összetételét, Raman-spektrumokat vettünk fel. Amint a 7.6. ábrán látható, a részecskék méretétôl nagyban függ, hogy tudtunk-e spektrumot detektálni. A kiértékelés során továbbra is az 5.8. és a 6.6. táblázatokat vettem figyelembe. A 7.6. A ábrán az oktaéderes kalcium-oxalát-dihidrát látható, míg a B ábrán túl kis méretúek a kristályok, ezáltal nem beazonosíthatóak. Az üveglemezekre futtatott csapadékban is megtaláltuk az x alakú részecskéket (7.6. ábra), melynek spektrumát a 7.7. ábrán tüntettem fel. Jól látható, hogy a kokristály fő összetevője a kalcium-oxalát-monohidrát, de a kalcit apró sávját is felfedezhetjük, ha $1086 \mathrm{~cm}^{-1}$ körül kémleljük a spektrumot.

Feltételezzük, hogy nem elegendően nagy felbontás mellett a mikroszkóp lencséje gömbszerú formát kölcsönzött minden komplex struktúrájú, rózsaszerú képződménynek is. Egy ilyen spektrumot a 7.8. ábrán mutatok be. Ezen a kalcium-oxalát-monohidrát, a -dihidrát, és a kalcit jeleit tudtam azonosítani. Ez azért érdekes, mert ezen kísérleti tapasztalat ellentétben áll az emberi vesekövekben megfigyelt kristályosodási folyamatokkal, miszerint tiszta kalcium-oxalát-dihidrát kő létezik csupán, a monohidrát forma pedig együtt kristályosodik más szervetlen vegyületekkel. 

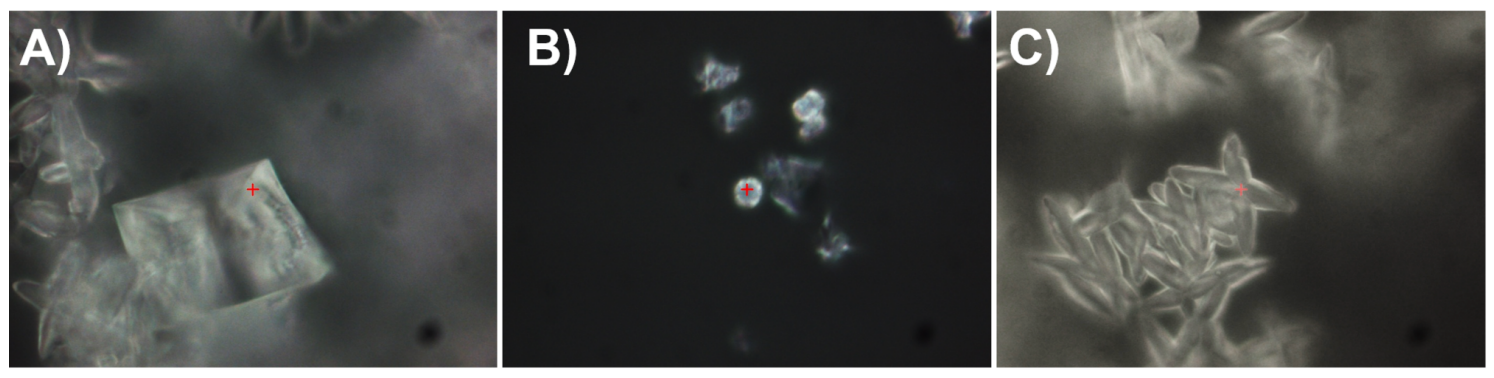

7.6. ábra. Raman-mikroszkóp képe néhány részecskékről, melyek spektrumát detektáltuk. Kalcium-oxalát-dihidrát (A), kalcium-oxalát-monohidrát-vaterit (B), és kalcium-oxalátmonohidrát-kalcit (C) kristályok. A kísérleti paraméterek: $c\left(\mathrm{CaCl}_{2}\right)=4,0 \mathrm{~mol} \cdot \mathrm{dm}^{-3}$, $c\left(\mathrm{Na}_{2} \mathrm{C}_{2} \mathrm{O}_{4}\right)=c\left(\mathrm{Na}_{2} \mathrm{CO}_{3}\right)=0,025 \mathrm{~mol} \cdot \mathrm{dm}^{-3}, q_{\mathrm{V}}=20 \mathrm{~cm}^{3} \cdot \mathrm{h}^{-1}$, és $\mathrm{pH}=10,0$.

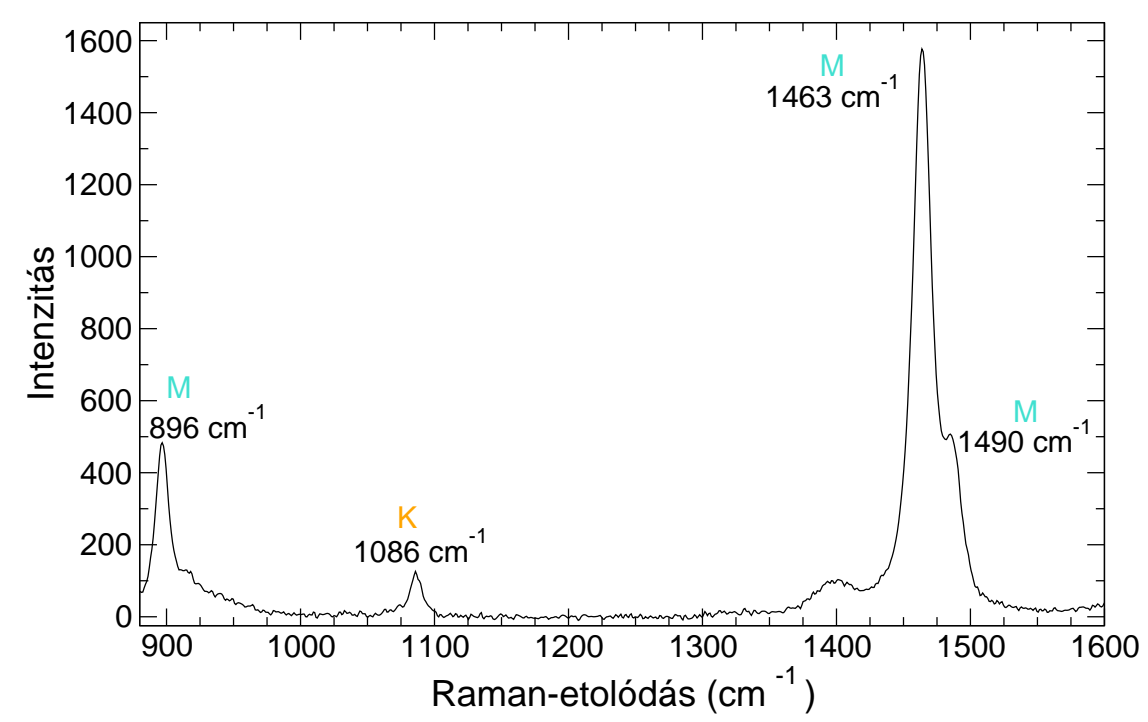

7.7. ábra. Raman-mikroszkóppal felvett Raman-spektrum: a kalcium-oxalát-monohidrát $(\mathrm{M})$ és a kalcit $(\mathrm{K})$ módosulatok jellemző sávjai. A kísérleti paraméterek: $c\left(\mathrm{CaCl}_{2}\right)=4,0 \mathrm{~mol} \cdot \mathrm{dm}^{-3}, c\left(\mathrm{Na}_{2} \mathrm{C}_{2} \mathrm{O}_{4}\right)=c\left(\mathrm{Na}_{2} \mathrm{CO}_{3}\right)=0,025 \mathrm{~mol} \cdot \mathrm{dm}^{-3}$, $q_{\mathrm{V}}=20 \mathrm{~cm}^{3} \cdot \mathrm{h}^{-1}$, és $\mathrm{pH}=10,0$.

További mérések során detektáltam tisztán kalcit, kalcium-oxalát-monohidrát, -dihidrát, kristályt is. Olyan esetek is előfordultak, amelyekben vaterit módosulatra bukkantam, amely kalcium-oxalát-monohidráttal együtt keletkezett. Különálló polikristályos vaterit gömböt ahogyan a pásztázó elektronmikroszkópiás felvételek alapján - nem tudtam azonosítani. Az $1630 \mathrm{~cm}^{-1}$ körül megjelenő sáv pedig a minta alatt lévő üveglapnak tudható be. 


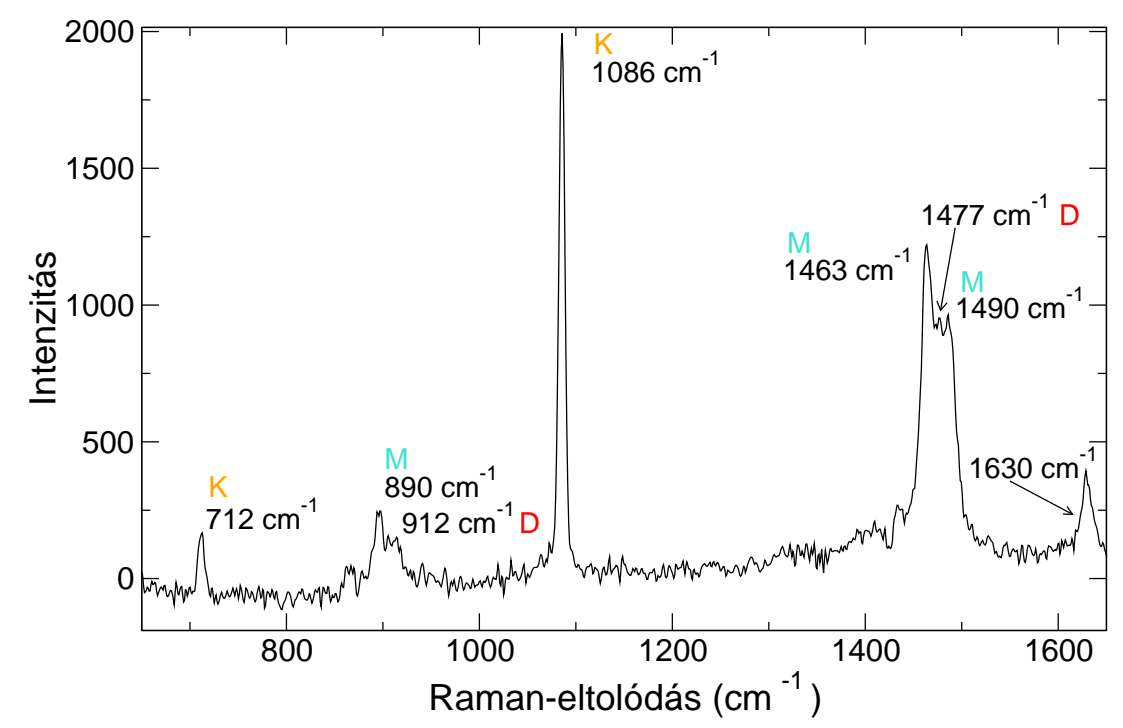

7.8. ábra. Raman-mikroszkóppal felvett Raman-spektrum: kalcium-oxalát-monohidrát (M) és -dihidrát $(\mathrm{D})$, valamint kalcit $(\mathrm{K})$ módosulatok jellemzô sávjai. A kísérleti paraméterek: $c\left(\mathrm{CaCl}_{2}\right)=4,0 \mathrm{~mol} \cdot \mathrm{dm}^{-3}, c\left(\mathrm{Na}_{2} \mathrm{C}_{2} \mathrm{O}_{4}\right)=c\left(\mathrm{Na}_{2} \mathrm{CO}_{3}\right)=0,025 \mathrm{~mol} \cdot \mathrm{dm}^{-3}$, $q_{\mathrm{V}}=20 \mathrm{~cm}^{3} \cdot \mathrm{h}^{-1}$, és $\mathrm{pH}=10,0$. 


\section{8. fejezet}

\section{Kalcium-karbonát csapadék elóállítása a karbamid-ureáz enzimreakcióban}

Az ureáz enzim a karbamid bontását katalizálja, miközben szén-dioxid és ammónia keletkezik végtermékként. Ezt az ún. biokatalitikus folyamatot a (8.1) egyenlet írja le:

$$
\mathrm{CO}\left(\mathrm{NH}_{2}\right)_{2}(\mathrm{aq})+\mathrm{H}_{2} \mathrm{O}(\mathrm{f}) \longrightarrow 2 \mathrm{NH}_{3}(\mathrm{aq})+\mathrm{CO}_{2}(\mathrm{aq})
$$

A reakció vizes közegben megy végbe, így az oldat kémhatását meghatározó, különféle sav-bázis folyamatok játszódnak le. Ezek az egyensúlyok a következô reakcióegyenletekkel adhatóak meg:

$$
\begin{aligned}
\mathrm{NH}_{3}(\mathrm{~g})+\mathrm{H}^{+}(\mathrm{aq}) & \rightleftharpoons \mathrm{NH}_{4}^{+}(\mathrm{aq}) \\
\mathrm{CO}_{2}(\mathrm{~g})+\mathrm{H}_{2} \mathrm{O}(\mathrm{f}) & \rightleftharpoons \mathrm{H}^{+}(\mathrm{aq})+\mathrm{HCO}_{3}^{-}(\mathrm{aq}) \\
\mathrm{HCO}_{3}^{-}(\mathrm{aq}) & \rightleftharpoons \mathrm{CO}_{3}^{2-}(\mathrm{aq})+\mathrm{H}^{+}(\mathrm{aq})
\end{aligned}
$$

\subsection{A karbamid és az ureáz enzim között lejátszódó órare- akció}

A hidroxidionra autokatalitikus karbamid-ureáz órareakció az irodalomból Prof. Taylor munkájának köszönhetően már korábban is ismert volt [30]. Kísérleteimben elsôként a cikkeikben publikált kísérletsorozat módosítását tûztem ki célul. Kénsav helyett sósavoldatot alkalmaztam annak tudatában, hogy kalcium-klorid-oldatot is fogok elegyíteni az oldathoz, és így (1) redukálhatom a komponensek számát, valamint (2) csökkenthetem a változók mennyiségét, ami a számolások során előnyös lesz. 


\subsubsection{A karbamid-ureáz enzim órareakció nyílt és zárt edényben}

Mágneses keverővel kevertettem a megfelelő sorrendben elegyített reaktánsok oldatát, miközben a kémhatásváltozást pH-mérô segítségével detektáltam. Ennek következtében tipikus S-alakú, szigmoidális görbéket kaptam a következő összetételnél: $0,08 \mathrm{~mol} \cdot \mathrm{dm}^{-3}$ karbamid, $20 \mathrm{u} \cdot \mathrm{cm}^{-3}$ ureáz enzim, és $1,85 \mu \mathrm{mol} \cdot \mathrm{dm}^{-3}$ brómkrezollila, valamint 2,23,0 $\mathrm{mmol} \cdot \mathrm{dm}^{-3}$ sósavoldat. Megfigyeltem, hogy nyílt rendszerben, azaz szabad felszín esetén, az egyre töményebb sósavoldat növeli a kezdeti, indukciós periódust, azonban a végső pH-t nem befolyásolja ( $\mathrm{pH}>9,0)$, lásd a 8.1. ábrát.

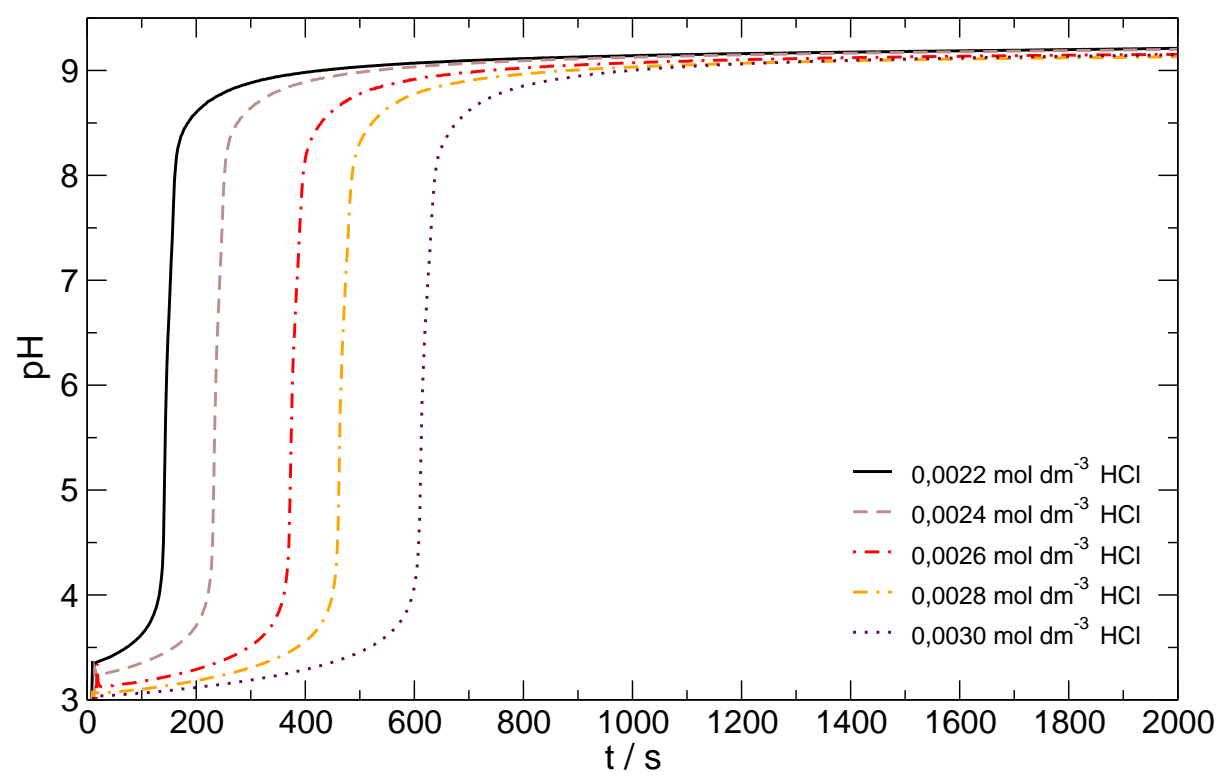

8.1. ábra. A sósavoldat mennyiségének változtatása a karbamid-ureáz enzim órareakcióban, nyitott edényben. Az elegy összetétele $0,08 \mathrm{~mol} \cdot \mathrm{dm}^{-3} \mathrm{karbamid}, 20 \mathrm{u} \cdot \mathrm{cm}^{-3}$ ureáz enzim, és $1,85 \mu \mathrm{mol} \cdot \mathrm{dm}^{-3}$ brómkrezollila, valamint $2,2-3,0 \mathrm{mmol} \cdot \mathrm{dm}^{-3}$ sósavoldat.

Tekintve, hogy a reakció eredményeképpen gáz halmazállapotú termékek is keletkezhetnek a (8.2) és a (8.3) egyensúlyoknak megfelelően, egy teljesen zárt reakcióedényben ismételtem meg a méréssorozatot. Ekkor azonban nem észleltem változást sem a görbék alakjában, sem pedig a végső kémhatás tekintetében. Így arra a következtetésre jutottam, hogy nyílt reaktorban is dolgozhatok, mely megkönnyíti a munkámat. A 8.2. ábrán található kísérleti hiba a kísérletek kezdetekor annak a következménye, hogy a pH detektálását az enzim hozzáadásának pillanatában kezdtem, és mivel a reaktoron csak egyetlen bemeneti nyílás található, az elektródot csak ezt követően tudtam a teljesen zárt edénybe helyezni. Így az elsô 10-20 másodpercben mért pH-adatok hamisak, azonban a pontos időmeghatározás célját szolgálják. 


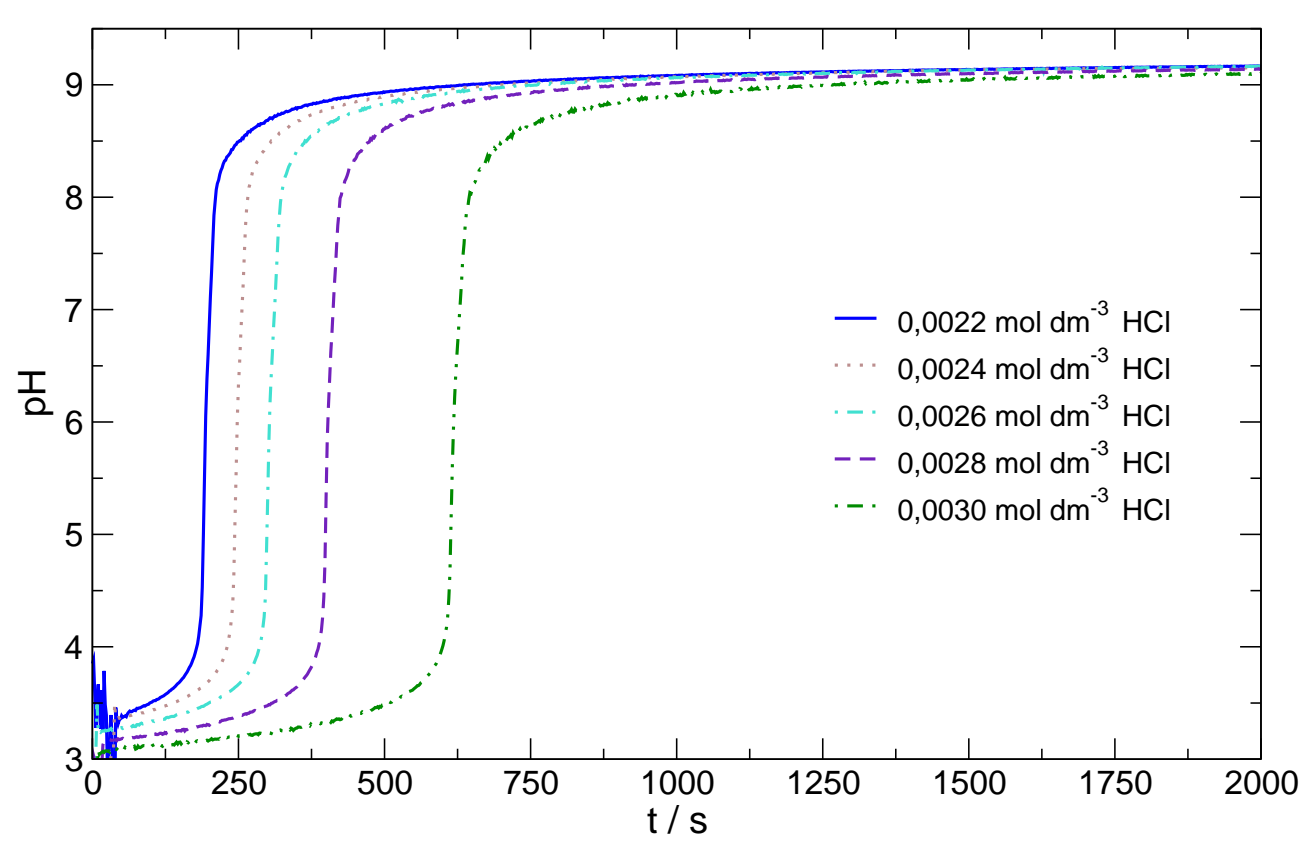

8.2. ábra. A sósavoldat mennyiségének változtatása a karbamid-ureáz enzim órareakcióban, zárt reaktorban. Az elegy összetétele: $0,08 \mathrm{~mol} \cdot \mathrm{dm}^{-3} \mathrm{karbamid}, 20 \mathrm{u} \cdot \mathrm{cm}^{-3}$ ureáz enzim, és $1,85 \mu \mathrm{mol} \cdot \mathrm{dm}^{-3}$ brómkrezollila, valamint $2,2-3,0 \mathrm{mmol} \cdot \mathrm{dm}^{-3}$ sósavoldat.

\subsubsection{A karbamid-ureáz enzim órareakció kalciumionokkal}

Kalciumionokat adva az elegyhez, a képződő szén-dioxid a (8.3) és a (8.4) egyensúlyokon keresztül karbonátionná alakul. A hipotézisünk az volt, hogy várhatóan a karbonátion csapadékot képez a kalciumionnal a (6.1) egyenletnek megfelelően, ami hatást gyakorol a lejátszódó jelenségekre.

\section{A kalciumionok mennyiségének változtatása}

Kalcium-kloridot $\left(1,0 \mathrm{mmol} \cdot \mathrm{dm}^{-3}\right)$ adva a jól-kevert rendszerhez fehér színú csapadék megjelenését figyeltem meg. Amint a 8.3. ábrán látható, a görbék alakja megváltozik: a szigmoidális alak eltorzul, és a pH-ugrás is később következik be. Nagy pH-értéket elérve egy kis törést is megfigyeltem a görbék alakjában. A kalcium-klorid mennyiségét azonban nem tudom minden határon túl növelni, ugyanis ha a kalcium-klorid-oldat koncentrációja $5,0 \mathrm{mmol} \cdot \mathrm{dm}^{-3}$-nél nagyobb, akkor az órareakció már nem megy végbe. 


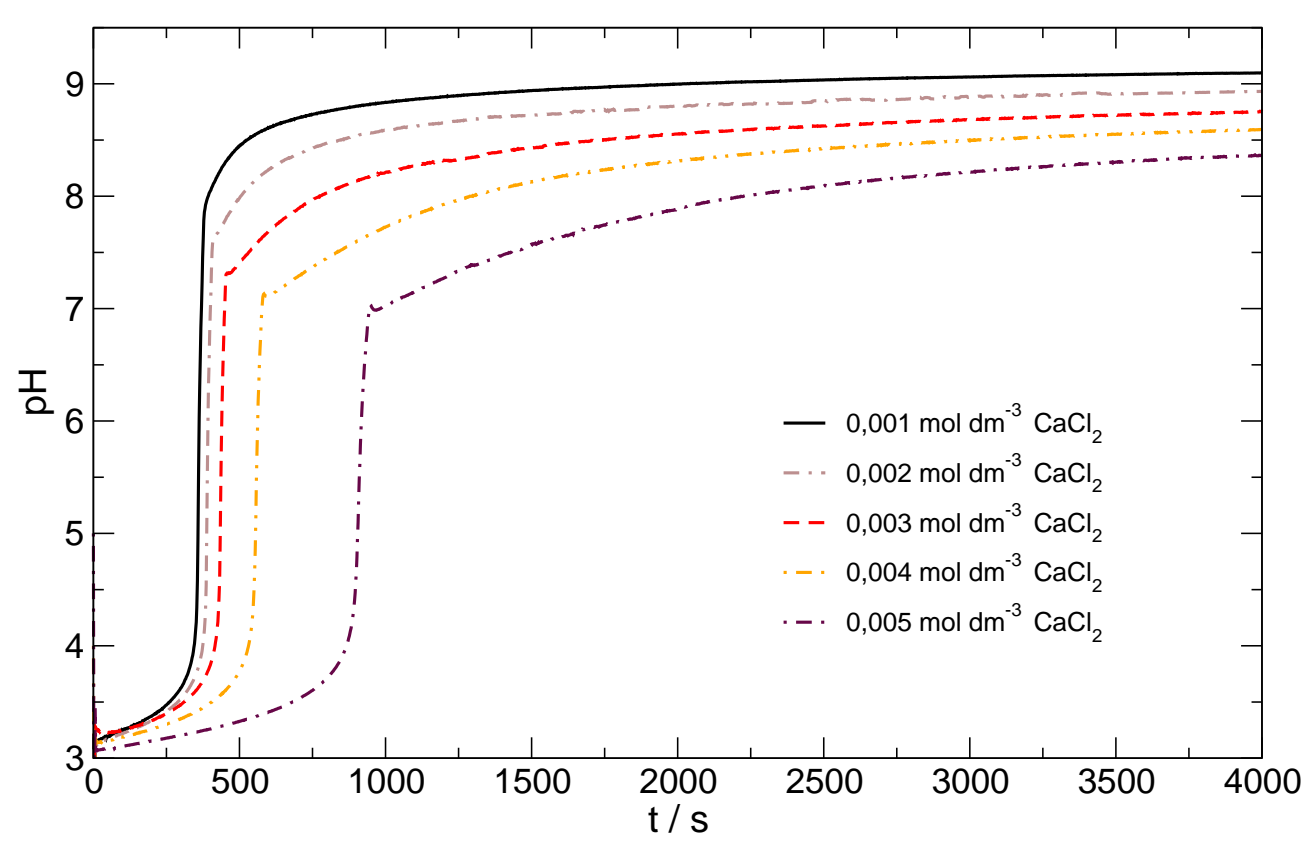

8.3. ábra. A kalcium-klorid-oldat mennyiségének változtatása a karbamid-ureáz enzim órareakcióban Az elegy összetétele: $0,08 \mathrm{~mol} \cdot \mathrm{dm}^{-3} \mathrm{karbamid}, 20 \mathrm{u} \cdot \mathrm{cm}^{-3}$ ureáz enzim, és $3,0 \mathrm{mmol} \cdot \mathrm{dm}^{-3}$ sósavoldat.

A növekvő csapadékmennyiséget turbiditásméréssel határoztuk meg $\lambda=400 \mathrm{~nm}$-en $2 \mathrm{~cm}^{3}$ térfogatú reaktánselegyben (8.4. ábra). Ezen kísérletsorozatban az előzôvel megegyező koncentrációkat alkalmaztam, úgy hogy a küvettában mágneses keverő segítségével biztosítottam a jól kevert rendszer meglétét. Ekkor azt tapasztaltuk, hogy minél töményebb a kalcium-klorid-oldat, annál nagyobb mennyiségú csapadék képződik, de a reakció továbbhaladásakor a csapadék mennyisége konstans, nem képződik több csapadék, mint ami a pH-ugrást követően levált. Ezekben a kísérletekben is látható a kalcium-klorid indukciós periódus-növelố hatása.

Az órareakciókat megismételtem brómkrezollila indikátor jelenlétében is. Ekkor úgy tûnt, mintha a csapadék a színváltást követôen kezdett volna keletkezni. Az azonban észrevehetô, hogy befolyásolta a kísérleteket, mert ebben az oldatban már 5,0 $\mathrm{mmol} \cdot \mathrm{dm}^{-3}$ kalcium-klorid-oldattal sem játszódott le órareakció (8.5. ábra). 


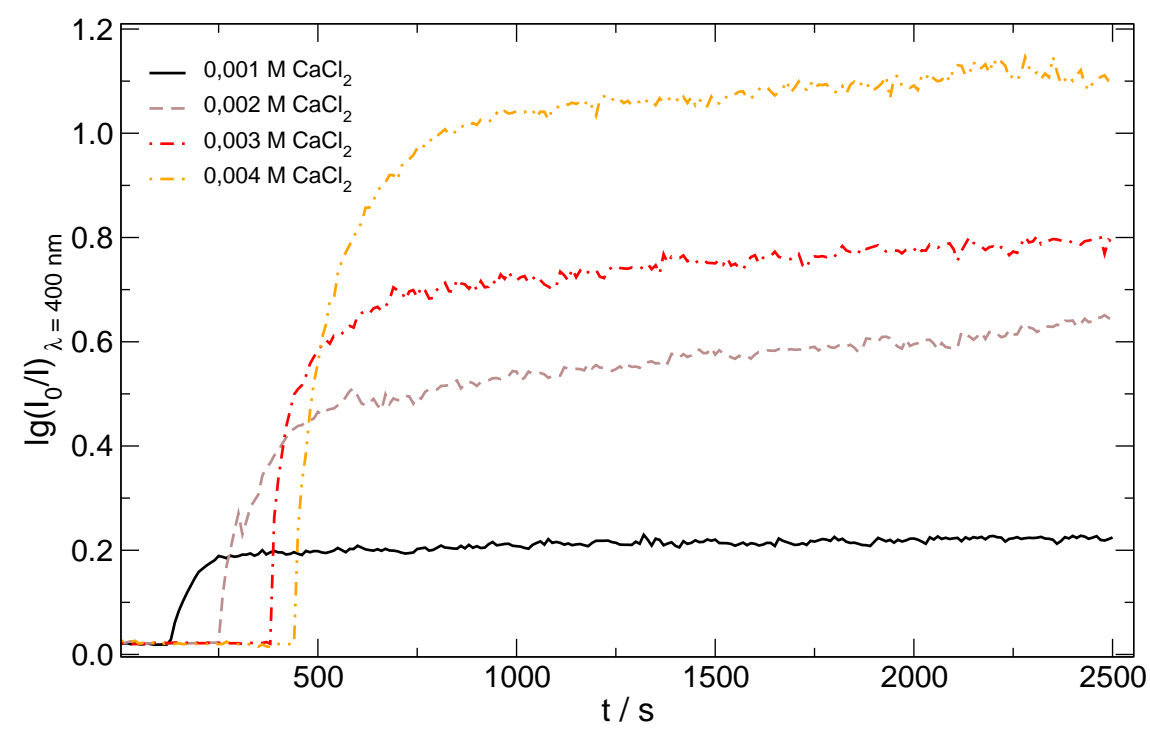

8.4. ábra. Turbiditásmérés a kalcium-klorid-oldat mennyiségének változtatása mellett a karbamid-ureáz enzim órareakcióban. Az elegy összetétele: $0,08 \mathrm{~mol} \cdot \mathrm{dm}^{-3} \mathrm{karbamid}$, $20 \mathrm{u} \cdot \mathrm{cm}^{-3}$ ureáz enzim, és $3,0 \mathrm{mmol} \cdot \mathrm{dm}^{-3}$ sósavoldat.

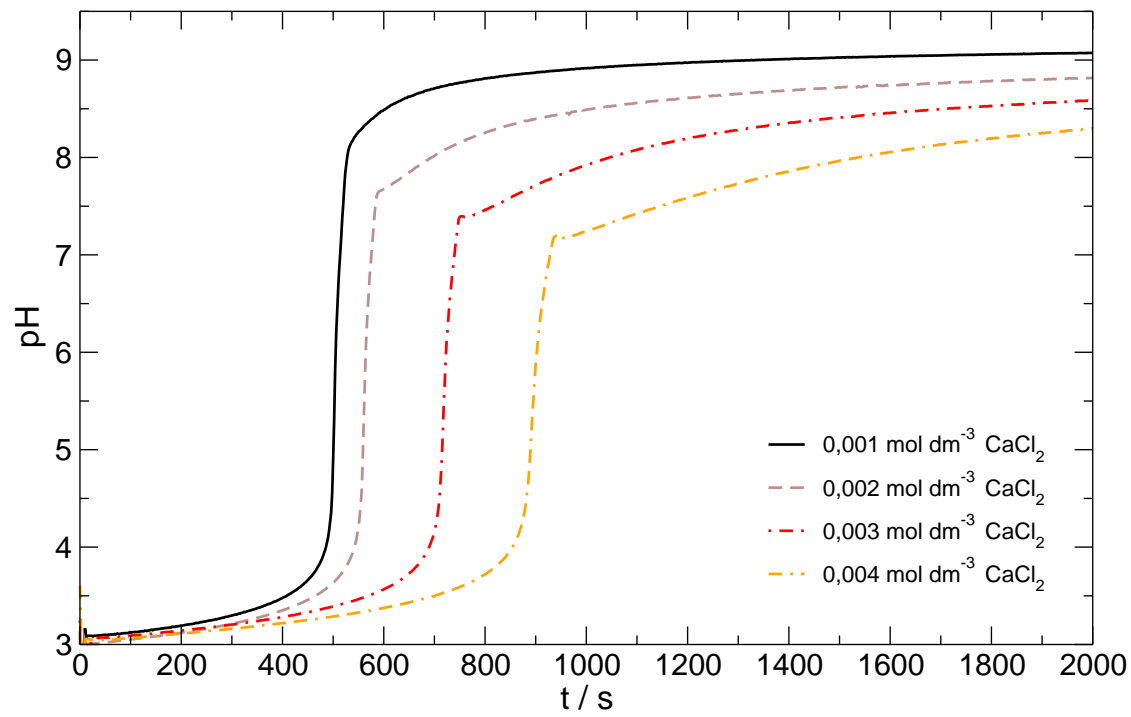

8.5. ábra. A kalcium-klorid-oldat mennyiségének változtatása a karbamid-ureáz enzim órareakcióban. Az elegy összetétele: $0,08 \mathrm{~mol} \cdot \mathrm{dm}^{-3}$ karbamid, $20 \mathrm{u} \cdot \mathrm{cm}^{-3}$ ureáz enzim, $1,85 \mu \mathrm{mol} \cdot \mathrm{dm}^{-3}$ brómkrezollila indikátor oldata és $3,0 \mathrm{mmol} \cdot \mathrm{dm}^{-3}$ sósavoldat. 
Annak érdekében, hogy pontos képet kapjunk a csapadékképződés és a pH-ugrás egymáshoz viszonyított megjelenéséról, a pH-t és a szürkeségi skála intenzitásokat párhuzamosan detektáltam. Amint az a 8.6. ábrán is látható, a csapadék csak a pH-ugrást követôen válik le. Ezen az ábrán még azt is megfigyelhetjük, hogy a csapadékképződés folyamata igen gyors.

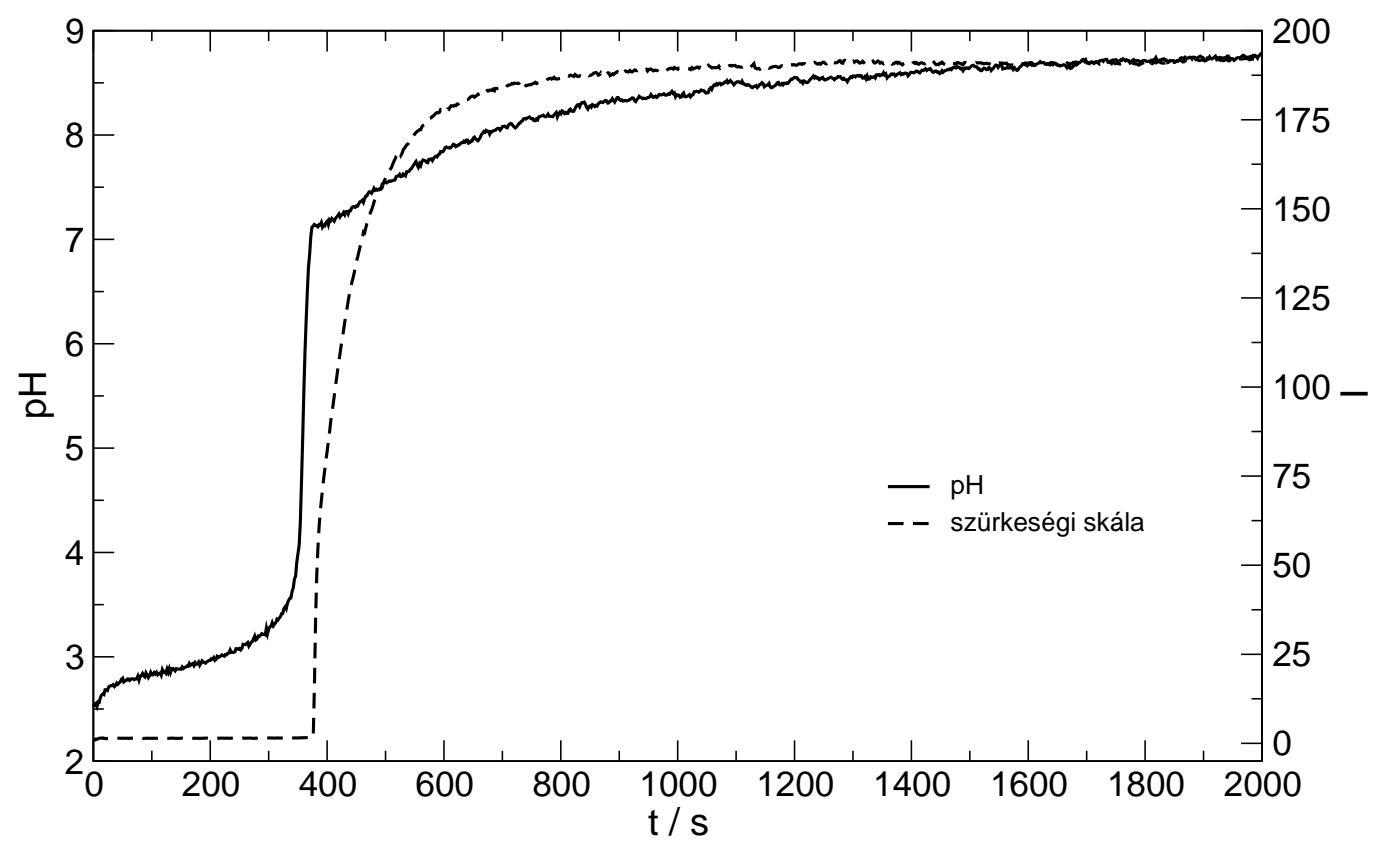

8.6. ábra. Szürkeségi skála intenzitás (I, szaggatott vonal) és pH-értékek (folytonos vonal) a karbamid-ureáz enzim órareakcióban. Az elegy összetétele: $0,08 \mathrm{~mol} \cdot \mathrm{dm}^{-3} \mathrm{karbamid}$, $20 \mathrm{u} \cdot \mathrm{cm}^{-3}$ ureáz enzim és $2,2 \mathrm{mmol} \cdot \mathrm{dm}^{-3}$ sósavoldat, $4,0 \mathrm{mmol} \cdot \mathrm{dm}^{-3} \mathrm{kalcium}-\mathrm{klorid}$ oldat.

\section{A kialakult csapadék pásztázó elektronmikroszkópiás vizsgálata}

Az órareakció során keletkezett csapadékról elektronmikroszkópiás felvételeket készítettem, melyek azt szemléltetik (8.7. ábra), hogy a mintában nem találtam kristályos fázis jelenlétét, ami arra enged következtetni, hogy nem kalcium-karbonát csapadék képződik. A két felvétel a minta két különböző területét hivatott bemutatni. 

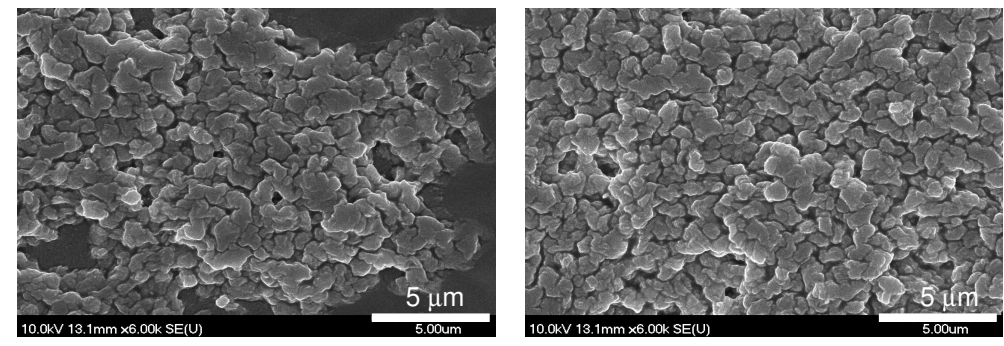

8.7. ábra. Pásztázó elektronmikroszkópiás felvételek a $0,08 \mathrm{~mol} \cdot \mathrm{dm}^{-3} \mathrm{karbamid}$, $20 \mathrm{u} \cdot \mathrm{cm}^{-3}$ ureáz enzim és $2,2 \mathrm{mmol} \cdot \mathrm{dm}^{-3}$ sósavoldat, $4,0 \mathrm{mmol} \cdot \mathrm{dm}^{-3} \mathrm{kalcium}-\mathrm{klorid}$ oldatok reakciójában képződött csapadékról.

\section{A kialakult csapadék Raman-mikroszkópiás vizsgálata}

Egy olyan méréssorozatot terveztem, melyben felvettük a por állagú ureáz enzim, kalciumkarbonát, kalcium-hidroxid, és az órareakció folyamán képződött ismeretlen összetételû csapadék spektrumát. Azt tapasztaltuk, hogy a csapadékunknak sem a kalcium-karbonát módosulataival, sem pedig a kalcium-hidroxiddal nincs közös sávja. Meglepő módon a kapott színkép hasonlított az enzim spektrumára, amint az a 8.8. ábrán is látható. A két spektrum közötti különbség, hogy kb. $40 \mathrm{~cm}^{-1}$-el eltolódtak a sávok, valamint a $100 \mathrm{~cm}^{-1}$-nél lévő sáv hiányzik. Ebből arra következtettem, hogy a kalciumionok lúgos közegben kicsapódnak az ureáz enzimmel.

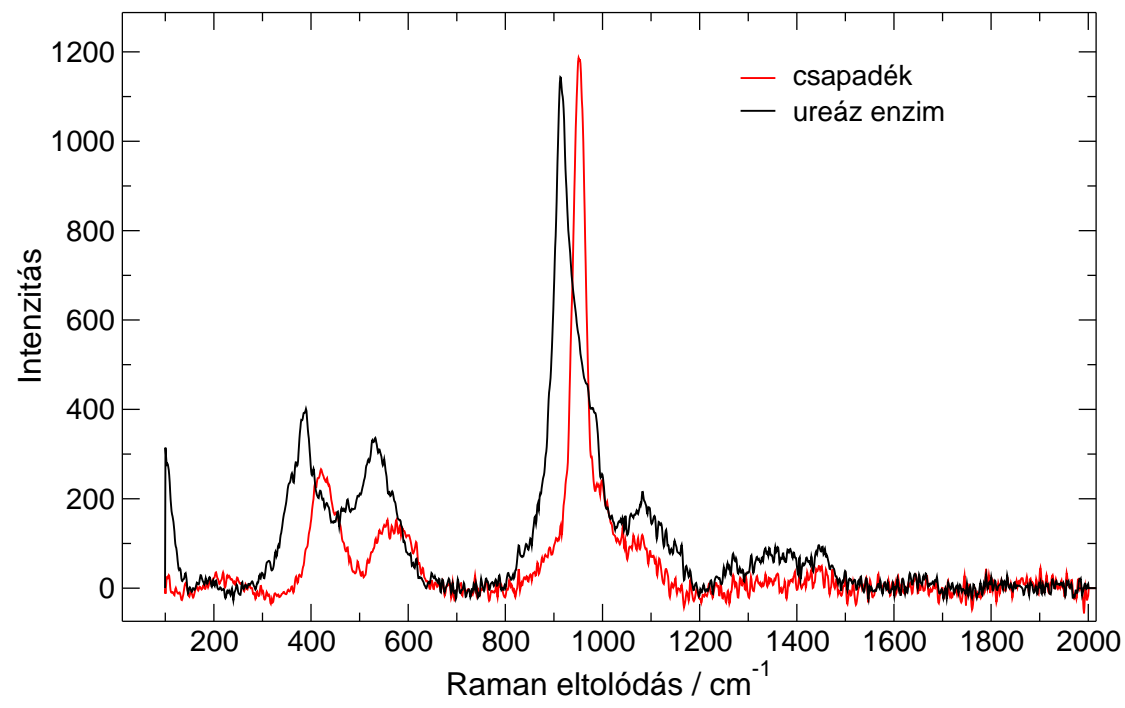

8.8. ábra. Az ureáz enzim és az órareakcióban képződött csapadék Raman-színképe. Az elegy összetétele: $0,08 \mathrm{~mol} \cdot \mathrm{dm}^{-3}$ karbamid, $20 \mathrm{u} \cdot \mathrm{cm}^{-3}$ ureáz enzim, 3,0 $\mathrm{mmol} \cdot \mathrm{dm}^{-3}$ sósavoldat és $4,0 \mathrm{mmol} \cdot \mathrm{dm}^{-3} \mathrm{kalcium}$-klorid-oldat. 


\section{Kontrollkísérlet karbamid nélkül}

Tisztázni szerettük volna, hogy vajon tényleg csak egy ureáz enzim-kalciumion csapadék jön létre lúgos kémhatású oldatban, vagy valami más folyamat megy végbe. Ezért kontrollkísérletként olyan reakcióelegyet állítottam össze, amelyhez karbamidot nem adtam, így az enzimmúködést megakadályoztam. Bórax-oldatban (puffer) oldottam fel az ureáz enzimet, kalcium-kloridot adtam hozzá, és megfigyeltem, hogyan válik le a csapadék (8.1. táblázat).

8.1. táblázat. Kontrollkísérletek karbamid hiányában.

\begin{tabular}{cccc}
\hline \hline bórax-oldat & kalcium-klorid & ureáz enzim & csapadék \\
\hline $\mathrm{pH}=9,18$ & $4,0 \mathrm{mmol} \cdot \mathrm{dm}^{-3}$ & - & - \\
$\mathrm{pH}=9,18$ & $4,0 \mathrm{mmol} \cdot \mathrm{dm}^{-3}$ & $50 \mathrm{u} \cdot \mathrm{cm}^{-3}$ & fehér színú \\
\hline \hline
\end{tabular}

A kapott csapadék sósav hatására nem pezsegve oldódott fel, Raman-spektruma pedig teljesen megegyezett a 8.8. ábrán lévő piros színú spektrummal (csapadék). Ebből arra következtettem, hogy nem kalcium-karbonát képződött, hanem a kialakult szilárd anyag annak következménye, hogy az ureáz enzim lúgos pH-n csapadékot képez a kalciumionokkal. Ez magyarázatot ad a periódusidô növekedésére valamint a végső $\mathrm{pH}$ csökkenésére is. 


\subsection{Lépcsốzetes kalcittermelés és az oszcilláló karbamid- ureáz enzimreakció}

Korábbi eredményeimre való tekintettel elhatároztam, hogy tovább növelem a komponensek koncentrációit $\left(10-40 \mathrm{u} \cdot \mathrm{cm}^{-3}, 0,25 \mathrm{~mol} \cdot \mathrm{dm}^{-3}, 0,50 \mathrm{~mol} \cdot \mathrm{dm}^{-3}\right.$, és $0,5 \mathrm{mmol} \cdot \mathrm{dm}^{-3}$ sósavoldat), hogy több karbonátion keletkezzen az oldatban, hátha abba a tartományba érünk, melyben kalcium-karbonátot tudunk létrehozni.

Ekkor nagyon különös dolgot tapasztaltam (8.10. ábra): a csapadék mennyisége lépcsôzetesen nô, miközben a pH-görbén oszcillációt figyelhetünk meg. Három lépcsô különül el egymástól 10 és $20 \mathrm{u} \cdot \mathrm{cm}^{-3}$ enzim mennyiségnél, és az első két lépcsőfok között jelentôs a szürkeségi skála intenzitás növekedése. Ezen szakaszokon kb. $300 \mu 1$ mintát vettem, és pásztázó elektronmikroszkóppal megvizsgáltam a kialakult csapadék mikroszerkezetét. Megállapítottam, hogy az elsô szakaszon amorf csapadék válik le (8.9. A ábra), vélhetôen az ureáz enzim-kalciumion csapadék, míg a további lépcsôkben romboéder, illetve téglatest alakú részecskék kristályosodnak ki (8.9. B és C ábra).

Tovább növelve az ureáz enzim mennyiségét, 5-6 oszcillációs periódus is megfigyelhetővé válik a pH-görbén (8.10. ábra). Ezzel párhuzamosan mindig nagyobb mennyiségú csapadék jelenik meg az oldatban. Az oszcilláció periódusának $(T)$ változása az enzimkoncentráció növelésének hatására: 350, 574, 1228, majd 558 s volt. Továbbá, azt is megfigyelhetjük, hogy a pH-ban történő növekedés és a csapadék leválása ezen kísérletek során egyszerre történik, ellentétben az órareakciónál tapasztaltakkal. Ezt követően a kalcium-klorid-oldat koncentrációját is változtattam $0,125,0,250$, és $0,750 \mathrm{~mol} \cdot \mathrm{dm}^{-3} \mathrm{között} \mathrm{(8.11.} \mathrm{ábra).} \mathrm{Eb-}$ ben a tartományban is megjelent a lépcsőzetes csapadékképződés és a pH-oszcilláció is, a periódusidő pedig 1326, 1280, és 525 s volt. Majd megnöveltem a karbamid koncentrációját 0,5 -rôl $1 \mathrm{~mol} \cdot \mathrm{dm}^{-3}$-re, a periódusidő pedig 500-ról 459-re csökkent (8.12. ábra). Mindegyik kísérlet során 0,34-0,35 pH-egység amplitúdójú oszcillációt tapasztaltam, mely a periódusok alatt csillapodik, csökkenő tendenciát mutat.
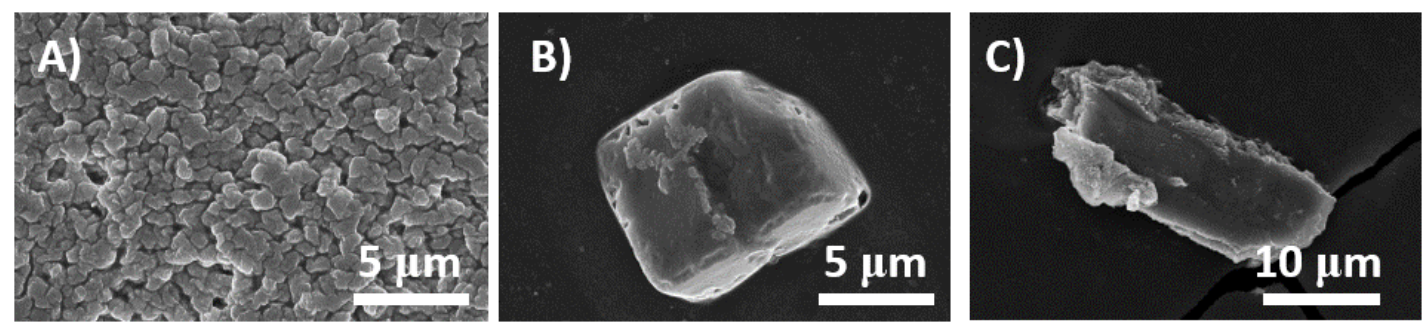

8.9. ábra. Pásztázó elektronmikroszkópiás felvételek az oszcilláló reakcióban képződött csapadékról $80 \mathrm{~s}$ (a), és $2500 \mathrm{~s}$ (b,c) alatt. Az elegy összetétele: $0,5 \mathrm{~mol} \cdot \mathrm{dm}^{-3} \mathrm{karbamid}$, $20 \mathrm{u} \cdot \mathrm{cm}^{-3}$ ureáz enzim, $0,5 \mathrm{mmol} \cdot \mathrm{dm}^{-3}$ sósavoldat és $0,25 \mathrm{~mol} \cdot \mathrm{dm}^{-3} \mathrm{kalcium}-\mathrm{klorid}$ oldat. 

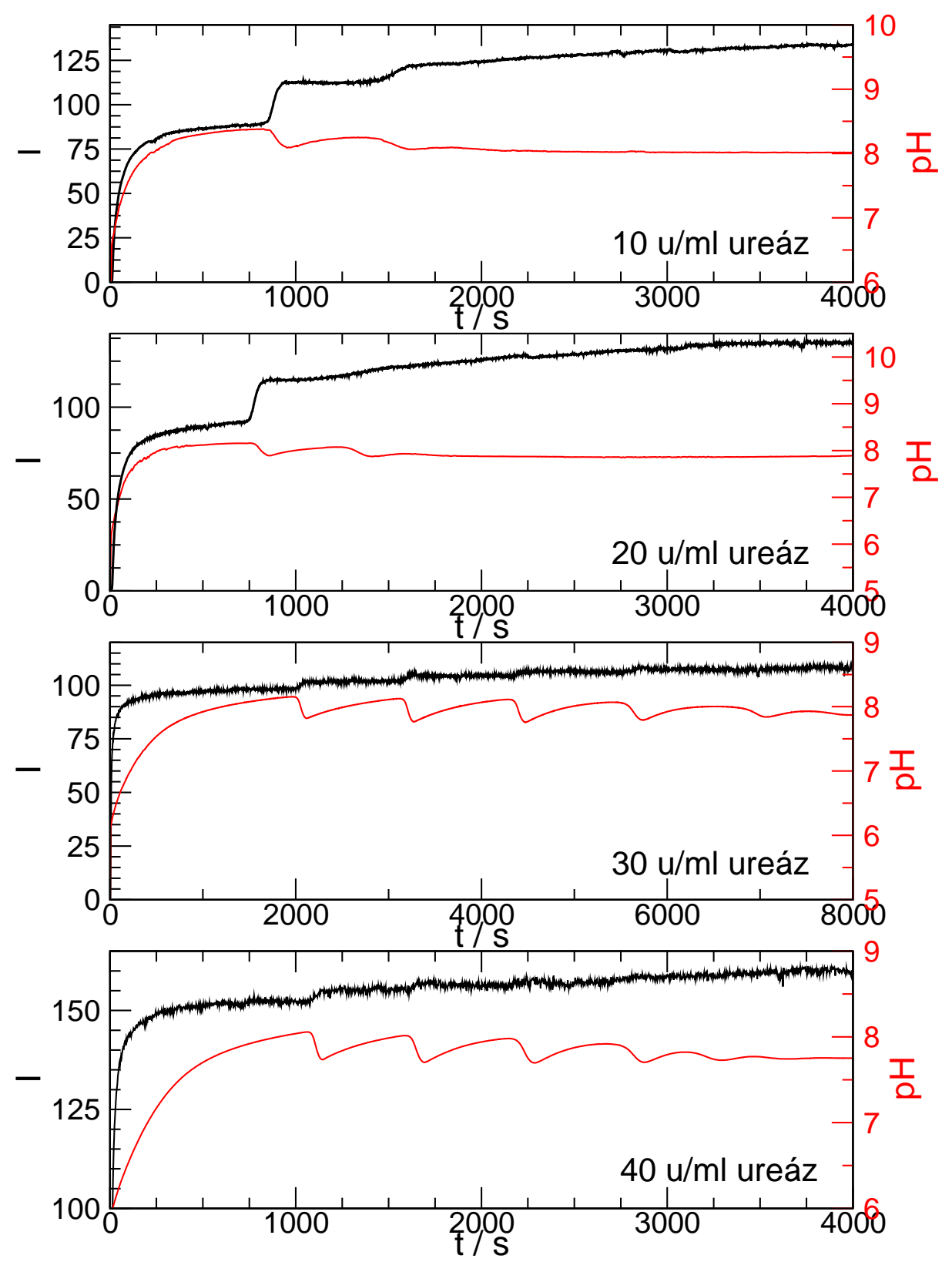

8.10. ábra. pH-oszcilláció és lépcsőzetes csapadékképződés a karbamid-ureáz enzimreakcióban. Az elegy összetétele: $0,5 \mathrm{~mol} \cdot \mathrm{dm}^{-3}$ karbamid, $10-40 \mathrm{u} \cdot \mathrm{cm}^{-3}$ ureáz enzim, $0,5 \mathrm{mmol} \cdot \mathrm{dm}^{-3}$ sósavoldat és $0,25 \mathrm{~mol} \cdot \mathrm{dm}^{-3} \mathrm{kalcium}$-klorid-oldat. 


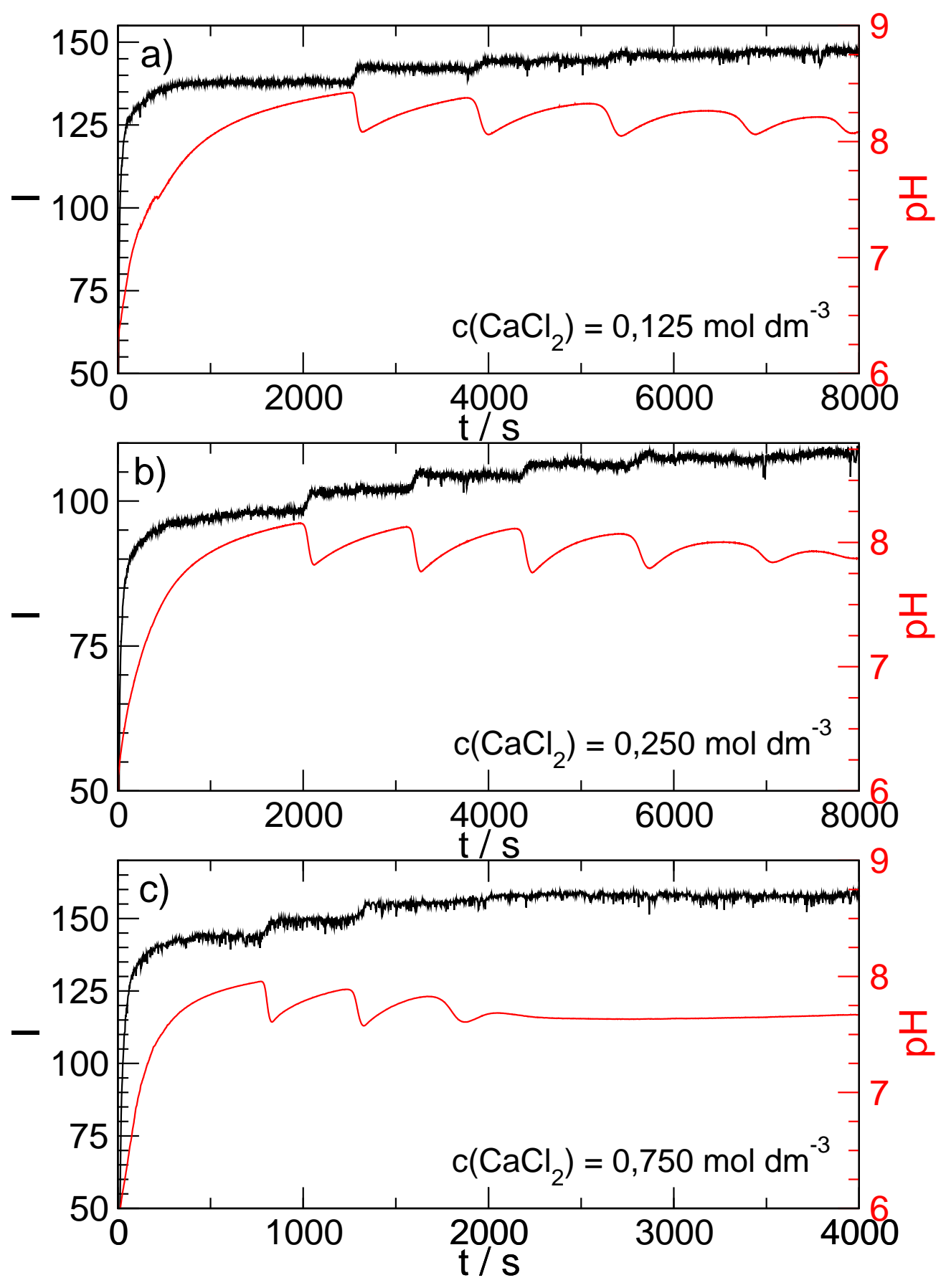

8.11. ábra. pH-oszcilláció és lépcsôzetes csapadékképződés a karbamid-ureáz enzimreakcióban. Az elegy összetétele: $0,5 \mathrm{~mol} \cdot \mathrm{dm}^{-3}$ karbamid, $30 \mathrm{u} \cdot \mathrm{cm}^{-3}$ ureáz enzim, $0,5 \mathrm{mmol} \cdot \mathrm{dm}^{-3}$ sósavoldat és $0,25-0,75 \mathrm{~mol} \cdot \mathrm{dm}^{-3} \mathrm{kalcium}-\mathrm{klorid}$-oldat. 

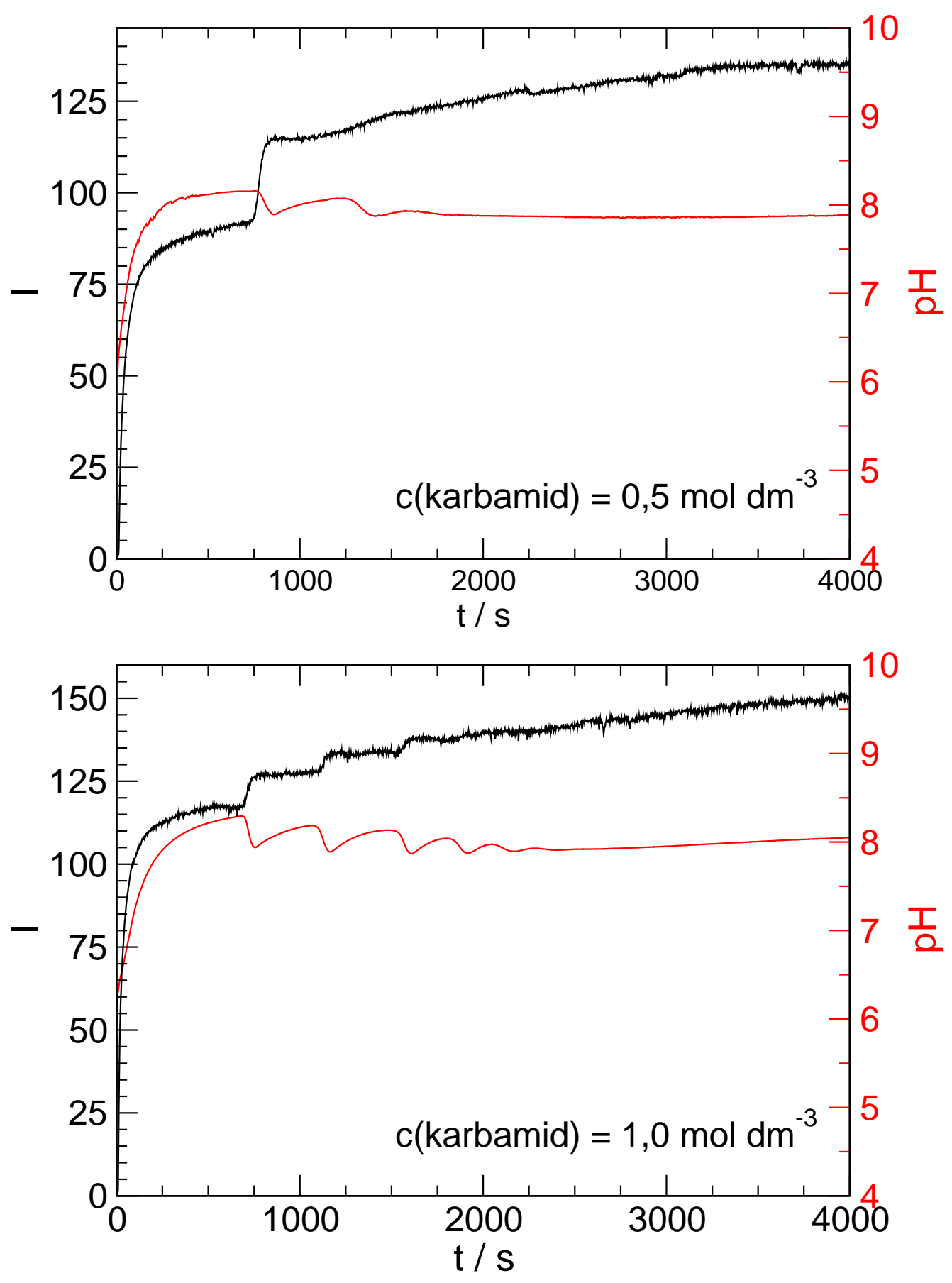

8.12. ábra. pH-oszcilláció és lépcsőzetes csapadékképződés a karbamid-ureáz enzimreakcióban. Az elegy összetétele: $0,5-1,0 \mathrm{~mol} \cdot \mathrm{dm}^{-3}$ karbamid, $20 \mathrm{u} \cdot \mathrm{cm}^{-3}$ ureáz enzim, $0,5 \mathrm{mmol} \cdot \mathrm{dm}^{-3}$ sósavoldat és $0,25 \mathrm{~mol} \cdot \mathrm{dm}^{-3} \mathrm{kalcium}$-klorid-oldat. 


\section{A koncentrációeloszlás számítása}

Annak érdekében, hogy a kalciumionok hatására bekövetkező pH-csökkenést meg tudjam magyarázni, koncentrációeloszlási görbéket számoltam. Ha feltételezzük, hogy kizárólag a 8.2. táblázatban összegzett komponensek, és azokból egyensúlyi folyamatok során létrejövő részecskék vannak jelen jelentős mennyiségben, valamint, hogy a képződő termék, ammónium-karbonát mennyisége $0,0-1,0 \mathrm{~mol} \cdot \mathrm{dm}^{-3}$ között van, akkor minden komponens mennyiségét meg tudjuk adni. A számításokat a Wolfram Mathematica [121] programmal végeztem, először kalciumionok nélkül, majd különböző kalciumion koncentrációk esetén (lásd a Függelék III.3. alfejezetét): 0,001; 0,010; 0,025; 0,010; 0,050; és 0,100 $\mathrm{mol} \cdot \mathrm{dm}^{-3}$.

8.2. táblázat. Az egyensúlyi számítások során figyelembe vett komponensek: az egyensúlyi állandók értékeit valamint a szilárd anyagok oldhatósági szorzatát megadó mennyiségek.

\begin{tabular}{llc}
\hline \hline komponensek & értékek & egyenlet \\
\hline $\mathrm{CaCO}_{3}(\mathrm{sz})$ & $\mathrm{p} K_{\mathrm{SP}}=8,35$ & $(6.1)$ \\
$\mathrm{Ca}(\mathrm{OH})_{2}(\mathrm{sz})$ & $\mathrm{p} K_{\mathrm{SP}}=5,19$ & $(6.2)$ \\
$\mathrm{CaOH}^{+}(\mathrm{aq})$ & $\log \beta=1,15$ & $(6.3)$ \\
$\mathrm{CaCO}_{3}(\mathrm{aq})$ & $\log \beta=3,15$ & $(6.4)$ \\
$\mathrm{CaHCO}_{3}^{+}(\mathrm{aq})$ & $\log \beta=1,00$ & $(6.5)$ \\
$\mathrm{HCO}_{3}^{-}(\mathrm{aq})$ & $\log \beta=6,35$ & $(6.6)$ \\
$\mathrm{H}_{2} \mathrm{CO}_{3}(\mathrm{aq})$ & $\log \beta=10,33$ & $(6.7)$ \\
$\mathrm{NH}_{4}^{+}(\mathrm{aq})$ & $\log \beta=9,24$ & $(8.2)$ \\
\hline \hline
\end{tabular}

Végül, az ammónium-karbonát koncentrációjának függvényében ábrázoltam a számítások végeredményeként kapott pH-értékeket (8.13. ábra). Jól látszik, hogy kalciumionok nélkül az oldat pH-ja nagyobb, mint 9, de egyre több kalciumionnal egyre kisebbé válik. A pH csökkenése kis ammónium-karbonát koncentráció mellett figyelhetô meg. A kalciumionok mennyiségének növekedésével azonban az oldat savasodása szélesebb ammónium-karbonát koncentrációtartományon következik be. Ha $0,1 \mathrm{~mol} \cdot \mathrm{dm}^{-3}$-re növelem a kalcium-klorid koncentrációját, akkor a számítások szerint még $1,0 \mathrm{~mol} \cdot \mathrm{dm}^{-3}$ ammónium-karbonát esetén is savas az oldat kémhatása. Ha a (8.3) és a (8.4) egyensúlyokat tekintjük, akkor ez nem egy váratlan esemény, ugyanis a karbonátion elvonásával hidrogéniont termelünk, ami savasítja az oldatot. 

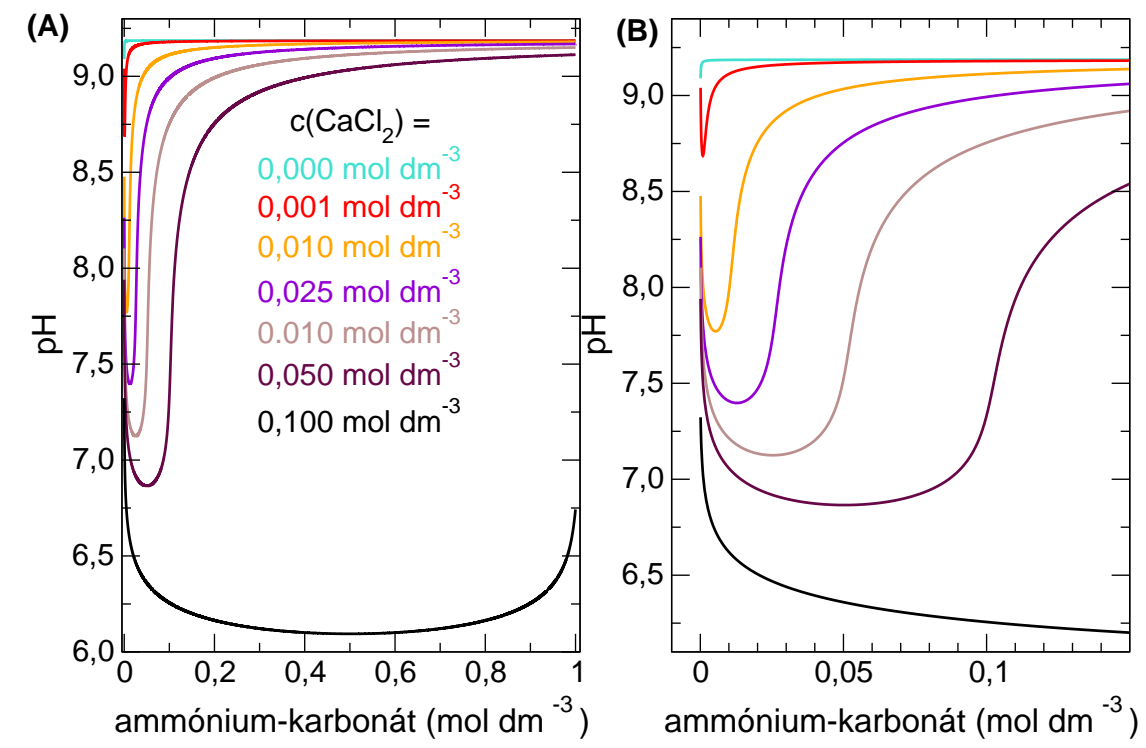

8.13. ábra. Számolt $\mathrm{pH}$ az ammónium-karbonát koncentrációjának függvényében különböző kalciumion-koncentrációk esetén. A jobb oldali ábrán kinagyított rész látható arról a tartományról, melyben intenzív pH-csökkenést tapasztaltam.

\subsubsection{A kialakult csapadék pásztázó elektronmikroszkópiás vizsgálata}

Pásztázó elektronmikroszkóppal vizsgáltam a kialakult csapadékot az oszcilláló reakció végbemenetele után $(t=8000 \mathrm{~s})$. Azt tapasztaltam, hogy a kis méretú részecskéken túl sok nagyobb, akár $\sim 10 \mu \mathrm{m}$ nagyságú romboéder is kristályosodott. Ezt az inhomogén részecskeméret-eloszlást az ún. Ostwald-féle öregedésnek tudjuk be.
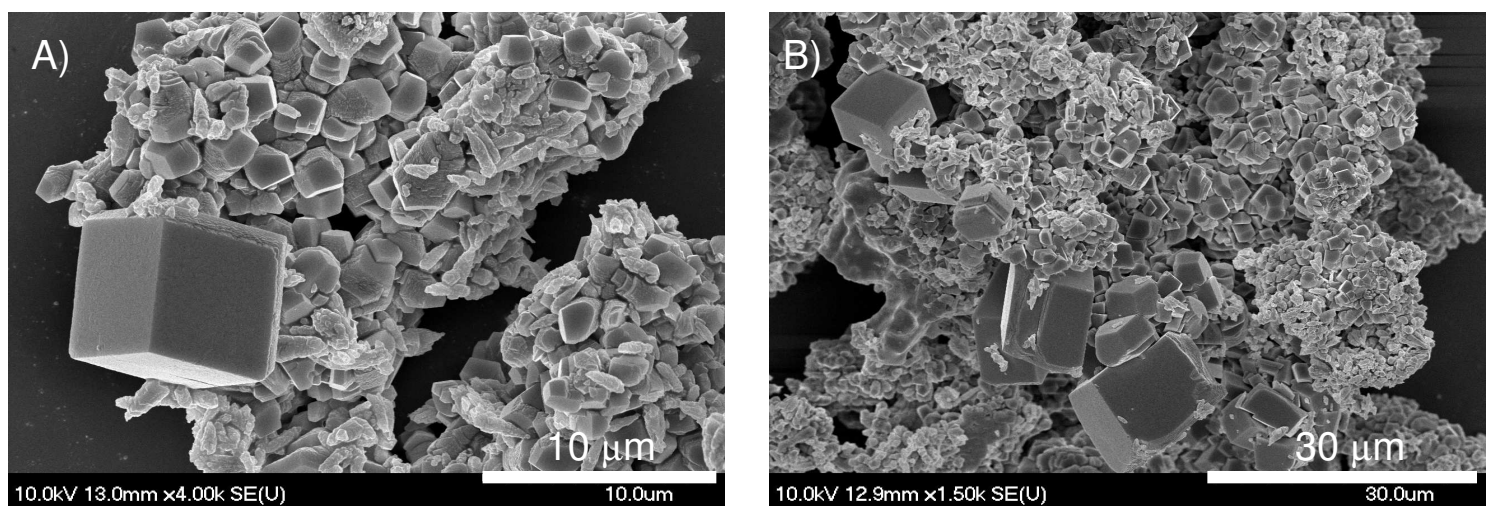

8.14. ábra. Pásztázó elektronmikroszkópiás felvételek az oszcilláló reakcióban kialakult csapadékról. Az elegy összetétele: $0,5 \mathrm{~mol} \cdot \mathrm{dm}^{-3}$ karbamid, $30 \mathrm{u} \cdot \mathrm{cm}^{-3}$ ureáz enzim, $0,5 \mathrm{mmol} \cdot \mathrm{dm}^{-3}$ sósavoldat és $0,25 \mathrm{~mol} \cdot \mathrm{dm}^{-3} \mathrm{kalcium}$-klorid-oldat. 


\subsubsection{A kialakult csapadék Raman-mikroszkópiás vizsgálata}

Raman-spektrumot vettem fel az oszcilláló reakcióban termelt csapadékról. Azt tapasztaltam, hogy jól definiált sávok találhatóak a színképen 712, 1086, 1436, és $1749 \mathrm{~cm}^{-1}$ hullámszámnál (lásd a 6.6. táblázatot). Ezek alapján a kalcium-karbonát kalcit módosulatát azonosítottam.

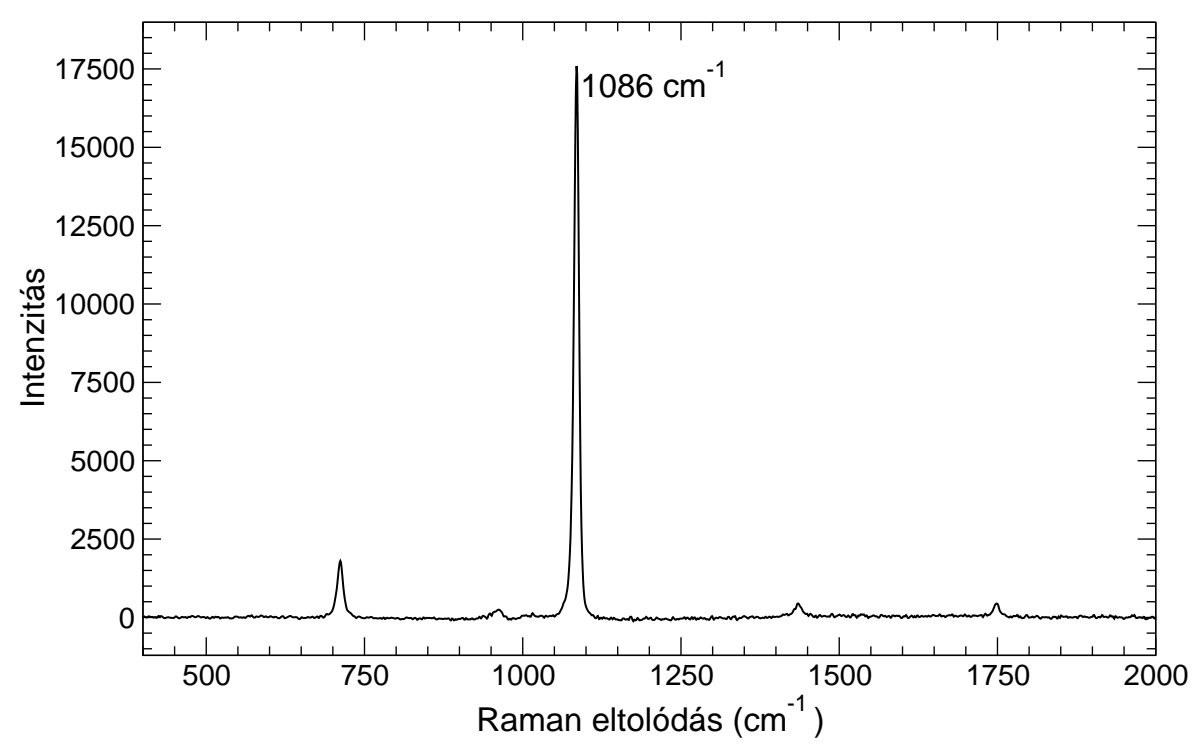

8.15. ábra. A karbamid-ureáz reakcióban kialakult kalcit módosulat spektruma. Az elegy összetétele: $0,5 \mathrm{~mol} \cdot \mathrm{dm}^{-3} \mathrm{karbamid}, 30 \mathrm{u} \cdot \mathrm{cm}^{-3}$ ureáz enzim, $0,5 \mathrm{mmol} \cdot \mathrm{dm}^{-3}$ sósavoldat, és $0,25 \mathrm{~mol} \cdot \mathrm{dm}^{-3} \mathrm{kalcium}-\mathrm{klorid}-$ oldat.

\subsubsection{Az oszcilláló kémiai reakció kontrollkísérlete}

Olyan kísérletsorozatot terveztem, melyben az enzim múködését a termék lassú injektálásával váltottam ki, azaz kalcium-klorid-oldatba áramoltattam ammónium-karbonát-oldatot. Eközben a pH-t és a szürkeségi skála intenzitásokat is detektáltam.

Sem pH-oszcillációt, sem pedig lépcsőzetes csapadékképződést nem tapasztaltam, bármelyik összetételt vagy bármelyik térfogat-áramlási sebességet is választottam.

Minden esetben a 8.16. ábrán látható tipikus lefutású szürkeségi skála intenzitás és pHgörbéket detektáltam. Azaz, a pH kezdetben az ammónium-karbonát-oldat áramoltatása végett nô. Eközben még nem értük el azt a tartományt, ahol az oldhatósági szorzatnak megfelelően leválik a csapadék. Majd amint a csapadék megjelenik, a pH csökkenni kezd. 


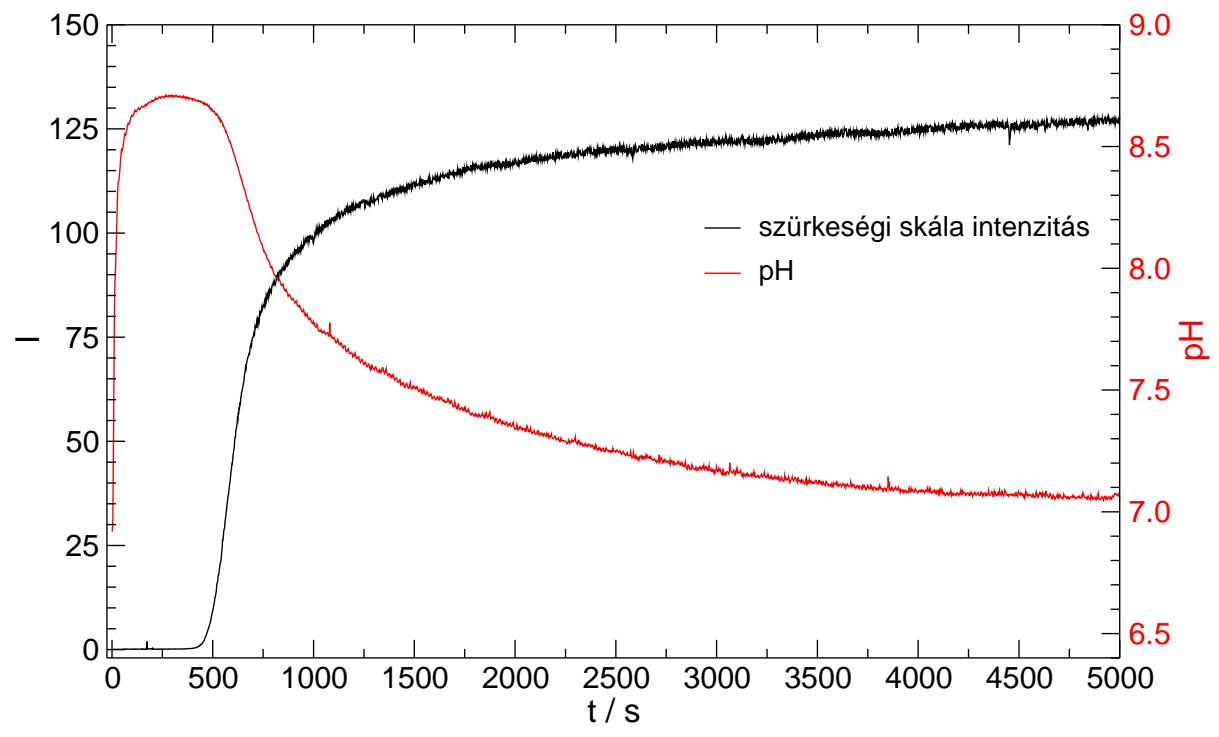

8.16. ábra. Ammónium-karbonát-oldat $\left(c=1,00 \mathrm{~mol} \cdot \mathrm{dm}^{-3}\right)$ áramoltatása $0,1 \mathrm{dm}^{3}$ térfogatú kalcium-klorid $0,125 \mathrm{~mol} \cdot \mathrm{dm}^{-3}$ koncentrációjú oldatába $0,25 \mathrm{~cm}^{3} \cdot \mathrm{h}^{-1}$ térfogat-áramlási sebességen.

A 8.3. táblázatban összegeztem a méréseket. A görbék alapján leolvastam a csapadék megjelenésének az idôpontját és a végsô pH-t. A változások a várakozásnak megfelelően alakultak, vagyis a kisebb koncentrációk és a kisebb térfogat-áramlási sebesség a csapadék időben későbbi megjelenését eredményezi. Kis áramlási sebességeknél adott idôpontban még nagyobb $\mathrm{pH}$-t detektáltam. A legsavasabb kémhatást $(\mathrm{pH}=6,00)$ pedig a legnagyobb $\left(5 \mathrm{~cm}^{3} \cdot \mathrm{h}^{-1}\right)$ térfogat-áramlási sebességen mértem. Ezek a tapasztalatok egyértelmúen a beáramló lúgos kémhatású anyag mennyiségével vannak összhangban.

8.3. táblázat. Kontrollkísérletek: ammónium-karbonát lassú injektálása kalcium-kloridoldatba.

\begin{tabular}{cccccc}
\hline \hline $\begin{array}{c}c\left(\left(\mathrm{NH}_{4}\right)_{2} \mathrm{CO}_{3}\right) \\
\mathrm{mol} \cdot \mathrm{dm}^{-3}\end{array}$ & $\begin{array}{c}c\left(\mathrm{CaCl}_{2}\right) \\
\mathrm{mol} \cdot \mathrm{dm}^{-3}\end{array}$ & $\begin{array}{c}q \mathrm{~V} \\
\mathrm{~cm}^{3} \cdot \mathrm{h}^{-1}\end{array}$ & reaktortípus & $\begin{array}{c}\text { csapadék } \\
\text { leválása }(\mathrm{s})\end{array}$ & $\begin{array}{c}\text { végsô } \mathrm{pH} \\
(t=8000 \mathrm{~s})\end{array}$ \\
\hline 1,0 & 0,25 & 0,250 & nyílt & $\sim 730$ & 6,45 \\
1,0 & 0,25 & 0,250 & zárt & $\sim 750$ & 6,25 \\
1,0 & 0,25 & 0,100 & nyílt & $\sim 1235$ & 6.60 \\
1,0 & 0,25 & 0,125 & nyílt & $\sim 410$ & 7,07 \\
1,0 & 0,25 & 0,500 & nyílt & $\sim 1390$ & 6,18 \\
1,0 & 0,25 & 5,000 & nyílt & $\sim 305$ & 6,00 \\
1,0 & 0,50 & 0,250 & nyílt & $\sim 1340$ & 6,18 \\
0,5 & 0,25 & 0,250 & nyílt & $\sim 2010$ & 6,55 \\
\hline \hline
\end{tabular}




\subsection{Az órareakció és az oszcilláció együttes megjelenése}

Ezt követôen arra voltam kíváncsi, hogy vajon megjelenik-e egyszerre az órareakció és az oszcilláció. Ennek érdekében töményebb sósavoldattal is végeztem kísérleteket. Abban az esetben, ha 2,5 $\mathrm{mmol} \cdot \mathrm{dm}^{-3}$, vagy annál töményebb sósavoldatot alkalmaztam, akkor nem játszódott le reakció. A 8.17. ábrán a $0,5 \mathrm{~mol} \cdot \mathrm{dm}^{-3}$ karbamid, $20 \mathrm{u} \cdot \mathrm{cm}^{-3}$ ureáz enzim, $1,5 \mathrm{mmol} \cdot \mathrm{dm}^{-3}$ sósavoldat, és $0,25 \mathrm{~mol} \cdot \mathrm{dm}^{-3} \mathrm{kalcium}$-klorid-oldat összetételú elegyben végbement folyamat $\mathrm{pH}$-görbéje és szürkeségi skálája látható. Az ureáz enzimet $t=100 \mathrm{~s}$-nál adtam a kevertetett többkomponensû oldathoz. A 8.17. ábra jobb szélén kinagyított részlet látható a reakció kezdetéről, amelyen megfigyelhetô az órareakcióra jellemző szigmoidális lefutású görbe, és az oszcilláció is. Jól látható, hogy ebben az esetben is, a pH-ugrás elóbb következik be, mint a csapadékleválás.
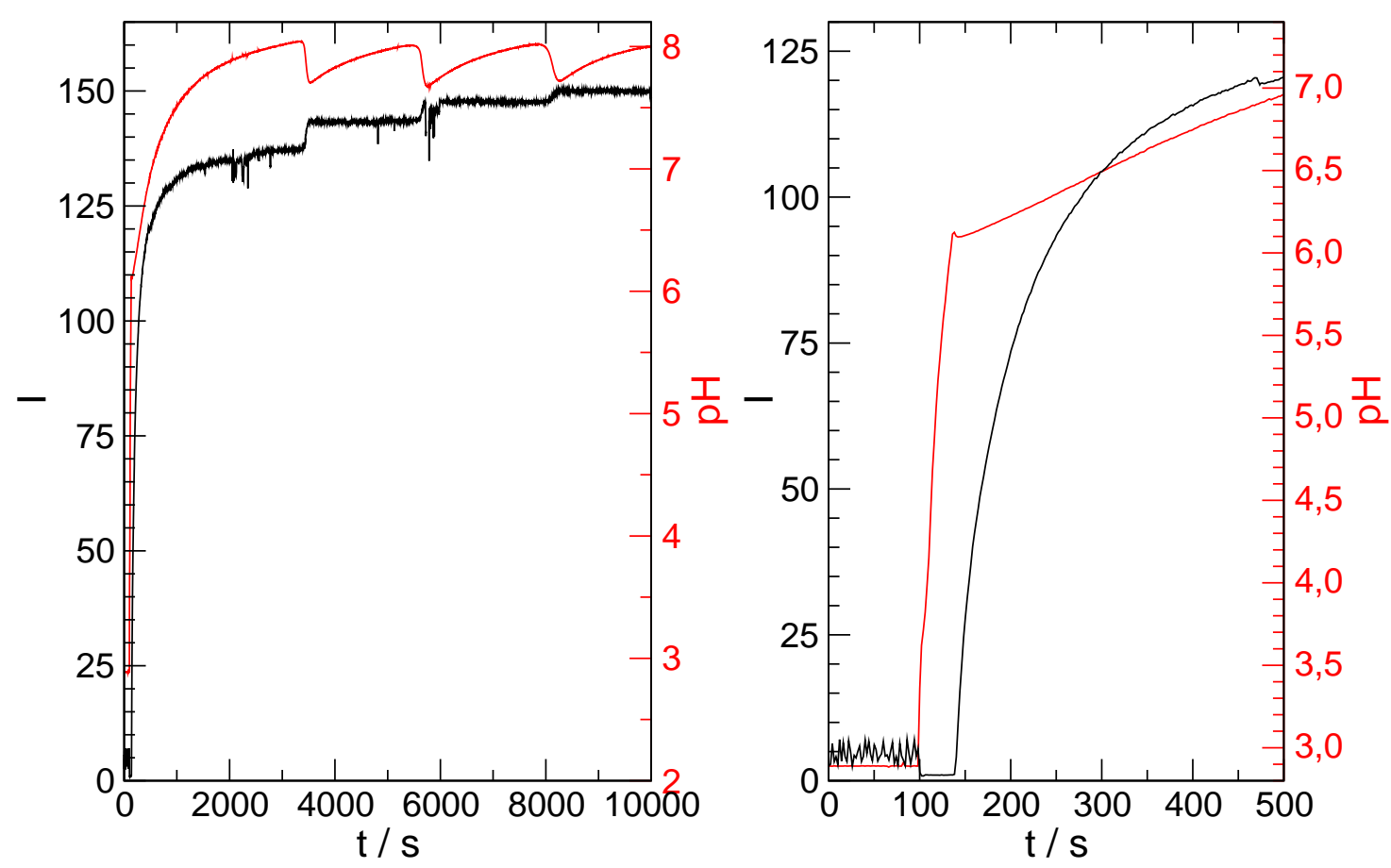

8.17. ábra. Az oszcilláció és az órareakció együttes megjelenése. A jobb oldali ábrán az órareakció kinagyítva látható. Az elegy összetétele: $0,5 \mathrm{~mol} \cdot \mathrm{dm}^{-3}$ karbamid, $20 \mathrm{u} \cdot \mathrm{cm}^{-3}$ ureáz enzim, 1,5 $\mathrm{mmol} \cdot \mathrm{dm}^{-3}$ sósavoldat, és $0,25 \mathrm{~mol} \cdot \mathrm{dm}^{-3}$ kalcium-klorid-oldat. 


\section{9. fejezet}

\section{Összefoglalás és diszkusszió}

Kutatócsoportunkban korábban szálas csapadékmintázatokra bukkantak a réz-oxalát és a kobalt-oxalát csapadékok felülnézeti vizsgálata során. Ezekben a kísérletekben a nagyobb sûrúségú fémsók oldatát nátrium-oxalát-oldatba áramoltatták, aminek következtében a csapadék sugárirányú szálaknak megfelelő alakban vált le. A szálas mintázat kialakulásának modellezésével kutatócsoportunk jelenleg is foglalkozik. Az eredmények alapján a beáramló nagy sûrûségú folyadék pereménél egy nagy konvekciós gyưrú alakul ki [85]. Oldalirányból nézve ezen a ponton a folyadék alján a mozgás előrefelé, míg a folyadékfelszín közelében visszafelé irányú. A peremtôl kicsit beljebb pedig a Rayleigh-Taylor-instabilitást figyelhetjük meg, ami gravitációs erőtérben az eltérő sûrűségkülönbségből adódó stabilitásvesztés. Az eltérő sûrúségkülönbségből eredő instabil rétegzôdés okozza rendszerünkben a Rayleigh-Taylor-instabilitást, melynek felülnézeti képe adja a szálakat. Ha ennek a rétegződésnek a keresztmetszeti (az áramlásra merőleges) metszetét tekintjük, akkor egy sor kisebb konvekciós gyưrút láthatunk, melyek egymással ellentétesen mozognak. Így egymás szomszédságában felfelé és lefelé áramló helyek alakulnak ki a folyadékban. A lefelé áramlás helyén pedig a csapadék ülepedése valósul meg, ezzel láthatóvá válnak a szálak.

Ha a reakcióedény alján nagyobb sûrűségú kalcium-klorid-oldatot áramoltattam be nátrium-oxalát vagy karbonát oldatába, akkor a konvekció miatt szálas mintázat formájában nem triviális csapadékeloszlás jött létre. Ezt a térbeli eloszlást képfeldolgozó rendszer segítségével jellemeztem. Ismertettem, hogy az oldatok közötti sưrúségkülönbségnek ezeknél a kísérleteknél is nagy szerep jut, és a csapadék szétterülése az eltelt idôvel négyzetgyökös összefüggéshez közelít. Ez azt jelenti, hogy a gyors reakció minden pillanatban követi, indikálja az áramlást, azaz a nagyobb sưrüségú folyadék pillanatnyi pozícióját. Ezzel ellentétben, a lassú csapadékképződés miatt korábban ezt nem tapasztalták a kutatócsoportunkban hasonló áramlásvezérelt kísérletek kiértékelésekor.

Ha összehasonlítjuk a kalcium-oxalát és a kalcium-karbonát mintázatának paramétereit, akkor azt tapasztalhatjuk, hogy azonos sưrúségkülönbség esetén a csapadékkorong hasonló területre terjed szét, a különbség kb. 3\%, lásd a 9.1. táblázatban szereplő külső kör sugarainak értékeit $\left(r_{\mathrm{k}}\right)$. Ez a nagyon kis eltérés még a kísérleti hibák tartományán belül van, 
tehát levonhatjuk azt a következtetést, hogy a mintázat kialakításában a sűrúségkülönbség az egyik döntő tényező.

A belső kör létrejötte azonban már nem függ ettől a paramétertől. Egy lehetséges magyarázatnak azt tartom, hogy mások az áramlási viszonyok a kísérlet kezdetekor, mint a reakció további részében. Amikor elindítom a kalcium-klorid-oldat beáramoltatását, akkor hirtelen gyorsan megindul az áramlás. Minél nagyobb területre áramlik adott térfogat-áramlási sebességgel az anyag, annál inkább lecsökken a nagy sưrúségú folyadék áramlásának sebessége (ezt mutatja tulajdonképpen a négyzetgyökös összefüggés is az 5.5., és a 6.4. ábrákon). Mivel a kísérlet elején kisebb méretű kristályok alakulnak ki, azt a nagymértékú, intenzív áramlás még képes magával ragadni és eloszlatni. Ez nagyon hasonló ahhoz a folyamathoz, ahogyan a folyó viszi magával a hordalékát. Amint külsôbb területekre érünk, az áramlás kisebb lesz, a részecskék pedig nagyobbak. A folyadékáramlás itt már nem képes magával vinni a csapadékrészecskéket. Ennek a határnak a pozíciója mindig az adott rendszertől függő tulajdonság, azaz minden csapadékmintázat esetén más-más értékeket várhatunk, és kapunk is. Az általam vizsgált reakciókban, azonos áramlás esetén a kalcium-oxalát részecskéi kisebbek, a belső kör ezáltal nagyobb. A nagyobb kristályokkal rendelkező kalcium-karbonát belső köre így kisebb méretet vesz fel.

A vegyesen karbonátiont és oxalátiont tartalmazó számítások azt mutatták, hogy a többféle csapadék zavartalanul megjelenik ugyanazon pH-értékeken, mint a tiszta csapadékok számításakor. A mintázatok esetén azt a tendenciát figyeltem meg, hogy a kalcium-karbonátot feleslegben tartalmazó minta rendelkezik a legkisebb sugárral. A szálak tekintetében a vegyes mintázatok közül a legszebb a nátrium-oxalát:nátrium-karbonát $=2: 1$ volt, hiszen itt megfelelően nagy a sưrúségkülönbség, azonban a 7.1. ábra alapján következtethetünk arra, hogy kevesebb szilárd anyag válik le, mint a csupán kalcium-oxalát csapadékot tartalmazó kísérlet esetén. Ez, valamint a feleslegben lévő kalcium-oxalát kisebb porsưrúsége kedvez a szálképződésnek.

A szálak tekintetében a kalcium-oxalát csapadék megjelenése előnyösebb, mint a kalciumkarbonáté. Ez annak köszönhetô, hogy a kalcium-karbonát porsúrúsége a nagyobb, így a gyorsabb ülepedésnek köszönhetôen egyenletesebben eloszlik a csapadék, és kevésbé láthatóak a szálak. A legelőnyösebb, ha lassú a csapadékképződés, így az csupán a szálak mentén dúsul fel (mint az előzőekben vizsgált réz-oxalát és kobalt-oxalát csapadék). Ezen kísérleti eredmények alapján a szálas csapadékmintázatok képződésének kritériumai:

(1) a reaktánsoldatok közötti nagy sûrúségkülönbség (ami a gravitációs áram létrejöttének is a feltétele),

(2) a lassú csapadékképződési reakció,

(3) a minél kisebb porsürüség, és

(4) a megfelelően kis mennyiségben leváló csapadék. 
9.1. táblázat. A kalcium-oxalát, a kalcium-karbonát és a kalcium-oxalát-kalcium-karbonát csapadékok mintázatának paraméterei.

\begin{tabular}{|c|c|c|c|c|c|}
\hline & \multirow{2}{*}{$\begin{array}{l}\text { kalcium-oxalát } \\
\text { mintázat }\end{array}$} & \multirow{2}{*}{$\begin{array}{c}\text { kalcium-karbonát } \\
\text { mintázat }\end{array}$} & \multicolumn{3}{|c|}{ vegyes mintázat } \\
\hline & & & $1: 2$ & $1: 1$ & $2: 1$ \\
\hline $\begin{array}{l}c\left(\mathrm{Na}_{2} \mathrm{C}_{2} \mathrm{O}_{4}\right) \\
\left(\mathrm{mol} \cdot \mathrm{dm}^{-3}\right)\end{array}$ & 0,010 & - & 0,0083 & 0,0125 & 0,0167 \\
\hline $\begin{array}{l}c\left(\mathrm{Na}_{2} \mathrm{CO}_{3}\right) \\
\left(\mathrm{mol} \cdot \mathrm{dm}^{-3}\right)\end{array}$ & - & 0,025 & 0,0167 & 0,0125 & 0,0083 \\
\hline $\begin{array}{l}c\left(\mathrm{CaCl}_{2}\right) \\
\left(\mathrm{mol} \cdot \mathrm{dm}^{-3}\right)\end{array}$ & 4,00 & 4,00 & 4,00 & 4,00 & 4,00 \\
\hline$q_{\mathrm{V}}\left(\mathrm{cm}^{3} \cdot \mathrm{h}^{-1}\right)$ & 20 & 20 & 20 & 20 & 20 \\
\hline $\mathrm{pH}$ & 9,0 & 10,0 & 10,0 & 10,0 & 10,0 \\
\hline$\Delta \rho\left(\mathrm{g} \cdot \mathrm{cm}^{-3}\right)$ & 0,3311 & 0,3312 & 0,3311 & 0,3311 & 0,3310 \\
\hline$r_{\mathrm{k}}(\mathrm{mm})$ & 77 & 75 & 50 & 71 & 79 \\
\hline$r_{\mathrm{b}}(\mathrm{mm})$ & 32 & 20 & - & 31 & 34 \\
\hline
\end{tabular}

A levált csapadék jellemzésekor azt is bemutattam, hogy a termodinamikailag instabil kalcium-oxalát-dihidrát kristályok áramlásvezérelt körülmények között szelektíven előállíthatók nagy feleslegben lévő kalciumionok és nagy térfogat-áramlási sebesség alkalmazásával. Ugyanakkor, a jól kevert rendszerben csupán a kalcium-oxalát-monohidrát kristályokat tudtuk azonosítani. A kalcium-karbonát csapadékmintázat esetén pedig azt is szemléltettem, hogy a kristályok morfológiája és méreteloszlása a térfogat-áramlási sebességgel szabályozható, azaz, ha $20 \mathrm{~cm}^{3} \cdot \mathrm{h}^{-1}$-nál kisebb térfogat-áramlási sebességet alkalmaztam, akkor a betáplálás helyétôl távolodva egyre nagyobb vaterit és kalcit kristályok keletkeztek. Ha $20 \mathrm{~cm}^{3} \cdot \mathrm{h}^{-1}$ vagy annál nagyobb a térfogat-áramlási sebesség, akkor pedig csupán kalcit kristályok képződtek. A 9.2. táblázatban összehasonlítottam a jól kevert és az áramlásvezérelt körülmények között képződő csapadékok tulajdonságait. A vegyesen karbonátiont és oxalátiont tartalmazó csapadékmintázat részecskéi pedig együtt kristályosodtak ki. Továbbá, több érdekes, x alakú kristályt is megfigyeltem, melyek összetétele kalcium-oxalátmonohidrát és kalcit keveréke.

A karbamid-ureáz enzimreakció során az ureáz enzim a karbamid bontását katalizálja, miközben szén-dioxid és ammónia keletkezik termékként. Ebben a rendszerben nemlineáris viselkedést, órareakciót figyeltek meg. A szakirodalomban már azt is ismertették, hogy a szén-dioxid-hidrogénkarbonátion-karbonátion egyensúlyokon keresztuil a karbonátiontartalmat kalciumionokkal elvonva szintén előállítható kalcium-karbonát csapadék. Mi ezt a nemlineáris viselkedéssel kívántuk kombinálni. A karbamid-ureáz hidroxidionra autokatalitikus órareakcióhoz kalciumiont adva az indukciós periódus nő, a végsố pH pedig csökken, melynek oka, hogy lúgos körülmények között, kis reaktánskoncentrációk esetén az ureáz enzim a kalciumionnal csapadékot képez. 
9.2. táblázat. A kalcium-oxalát és a kalcium-karbonát csapadékok jellemzői jól kevert és áramlásvezérelt kísérletek során.

\begin{tabular}{lcccc}
\hline \hline & kalcium-oxalát csapadék & \multicolumn{2}{c}{ kalcium-karbonát csapadék } \\
\hline egyezés: & & & $\begin{array}{l}\text { kalcit és vaterit is képződik, ha } \\
(1) \text { jól kevert az oldat, vagy } \\
\text { (2) } q_{\mathrm{V}} \geq 20 \mathrm{~cm}^{3} \cdot \mathrm{h}^{-1}\end{array}$ \\
& & & azonos morfológia & \\
eltérések: & jól kevert & áramlásvezérelt & jól kevert & áramlásvezérelt \\
vegyület & $\mathrm{COM}$ & $\mathrm{COM}, \mathrm{COD}$ & kalcit, vaterit & csak kalcit \\
méret & $\mu \mathrm{m}$ alatt & $1-13 \mu \mathrm{m}$ & $4-5 \mu \mathrm{m}$ & $1-24 \mu \mathrm{m}$ \\
alak & lekerekített & oktaéder, virág & gömb, romboéder & romboéder \\
struktúra & egyszerún & komplexebb & egyszerú & egyszerú \\
\hline \hline
\end{tabular}

Ezáltal a kevesebb aktív enzim hatását láthatjuk a diagramokon. A reaktánsok töményebb oldatait felhasználva az enzimmúködés következményeként kalcit alakul ki. Továbbá, tranziens pH-oszcillációt és lépcsôzetes kalcitképződést is megfigyeltem, melynek modellezése jelenleg folyamatban van. Ezekben a kísérletekben is csökkent a végső $\mathrm{pH}$, melynek oka, hogy a kalciumion a termékként képződő szén-dioxidot a hidrogén-karbonátion-karbonátion egyensúlyon keresztül elvonja, miközben hidrogénion szabadul fel. Az elôzetes eredmények közül a IV.1. ábra a Függelék IV. fejezetében található, melyen a periódusidő, és az amplitúdó is jó egyezést mutat a kísérleti tapasztalatokkal. Annyit biztosan tudunk, hogy a kalcium-karbonát csapadék kialakulása a pH csökkenését eredményezi, valamint, hogy az enzim nagy része a kalciumionnal kialakított csapadék következtében inaktív, ami egy nagyon lassú karbonátiontermelést eredményez. Ezt igazoltam is a pásztázó elektronmikroszkópiás felvételek segítségével (8.9. A ábra). A modellezés során figyelembe kell vennünk olyan további paramétereket, mint például egy bizonyos túltelítési határérték, ezen túl a kisebb részecskék visszaoldódásának és kikristályosodásának a dinamikus egyensúlyát is. $\mathrm{Az}$ enzim a karbamid bontása során lúgosítja az oldatot. Amint elegendô mennyiségú karbonátion termelődik, kalciumionokkal együtt telítetté, ezt követően túltelítetté válik az oldat, majd a csapadék hirtelen leválik. Ezzel egyidőben a karbonátionok szilárd fázisba mennek, az oldatban protonok maradnak vissza, azaz a pH gyorsan lecsökken. Majd a kis mennyiségú enzim folytatja a lassú karbonátiontermelést, azonban csak egy bizonyos túltelítettség esetén fog újból leválni a csapadék. Feltehetôen ez a folyamat ismétlódik a periódusok alatt.

Készítettem egy összefoglaló táblázatot a különböző kísérleteim során előállítható módosulatokról, és méretükről (9.3. táblázat). 
9.3. táblázat. A kalcium-oxalát és a kalcium-karbonát részecskék a különböző kísérletek során.

\begin{tabular}{|c|c|c|c|c|c|}
\hline & \multicolumn{4}{|c|}{ "áramlásvezérelt csapadékmintázatok } & \multirow{3}{*}{$\begin{array}{c}\text { enzimreakció } \\
\text { kalcium-karbonát }\end{array}$} \\
\hline & \multicolumn{4}{|c|}{$\begin{array}{l}\text { kalcium-oxalát csapadék kalcium-karbonát csapadék } \\
\text { térfogat-áramlási sebesség }\left(\mathrm{cm}^{3} \cdot \mathrm{h}^{-1}\right) \text { : }\end{array}$} & \\
\hline & 20 & 100 & $<20$ & $\geq 20$ & \\
\hline módosulat & $\begin{array}{l}\text { fóként } \\
\text { COM }\end{array}$ & $\begin{array}{l}\text { főként } \\
\text { COD }\end{array}$ & $\begin{array}{l}\text { kalcit és } \\
\text { vaterit }\end{array}$ & kalcit & kalcit \\
\hline morfológia & $\begin{array}{l}\text { COM: } \\
\text { virág }\end{array}$ & $\begin{array}{c}\text { COD: } \\
\text { oktaéder }\end{array}$ & $\begin{array}{l}\text { gömb és } \\
\text { romboéder }\end{array}$ & romboéder & romboéder \\
\hline méret & & $\begin{array}{l}\text { nogén } \\
3 \mu \mathrm{m}\end{array}$ & $\begin{array}{c}\text { inhomogén } \\
1-2\end{array}$ & $\begin{array}{l}\text { inhomogén } \\
\mu \mathrm{m}\end{array}$ & $\begin{array}{l}\text { inhomogén } \\
0,5-15 \mu \mathrm{m}\end{array}$ \\
\hline $\begin{array}{l}\text { térbeli } \\
\text { eloszlás }\end{array}$ & $\begin{array}{r}\text { a betáp } \\
\mathrm{d} \\
\mathrm{g}\end{array}$ & $\begin{array}{l}\text { helyétől s } \\
\text { ntenzív } \\
\text { pzốdés } \\
\text { zítja }\end{array}$ & $\begin{array}{c}\text { irányban nô a } 1 \\
\text { jól definiált } \\
\text { eloszlások } \\
\text { 1, 3, } 7 \text { cm-nél }\end{array}$ & $\begin{array}{l}\text { zecskeméret: } \\
\text { de az intenzív } \\
\text { gócképző́dés } \\
\text { torzítja }\end{array}$ & $\begin{array}{l}\text { nem } \\
\text { releváns }\end{array}$ \\
\hline
\end{tabular}

Látható, hogy mind a kalcium-oxalát, mind a kalcium-karbonát esetében az áramlásnak szerepe van abban, hogy milyen módosulat(ok) képződik(/nek). A térfogat-áramlási sebesség ezáltal egy olyan paramétert adott a kezembe, ami szinte egy „kapcsolóként” múködött, és segítségével szabályozni tudtam a kialakult struktúrákat. Ezen túl a kalcium-karbonát kalcit formáját kétféle módszer segítségével is elő tudom állítani: az enzimreakcióban és intenzív áramlással egyaránt. 


\section{Chapter 10}

\section{Summary and Discussion}

Our research group has discovered filament-containing precipitate patterns via studying cobalt oxalate and copper oxalate precipitates. In these experiments, concentrated, dense metal ion solutions were pumped into dilute sodium oxalate solution from below. As a result, precipitation occurred in a form of filaments. According to our modeling study - a convection roll appears at the rim of the inflowing dense solution, that is particles move forward at the bottom of the dense liquid in radial direction, then turn back and flow backward near to the liquid surface [85]. A little farther from the rim, Rayleigh-Taylor instability arises, caused by the density difference in the gravitational field as a result of an unstable stratification. If we take the cross-section (perpendicularly to the flow) of this stratification, there are a number of small convection rolls that move in the opposite direction. It means that adjacent upward and downward flowing places form inside the fluid, thus, precipitate settles down at the location of downward flow, which creates the filaments.

In this work, convection was created by pumping dense calcium chloride solution into sodium oxalate or carbonate solutions, which caused a spatial distribution of calcium oxalate or calcium carbonate precipitates. These precipitate patterns were characterized by photographs. We demonstrated that the density difference between the solutions plays a key role in these experiments, and the precipitate front spreading approaches a square-root relationship over time (see Figures 5.5, and 6.4). Accordingly, the fast precipitation follows and indicates the instantaneous position of the moving, dense liquid. On the contrary, this was not experienced by evaluating similar flow-driven experiments, where slow precipitation reactions took place.

The outer circle of calcium oxalate and calcium carbonate patterns were almost identical at same density differences (Table 10.1). The average deviation between the circles was within the range of experimental errors $(\sim 3 \%)$, from which we can conclude that the density difference is one of the key factors, which govern the formation of filament-containing precipitate patterns.

The appearance of the inner circle, however, does not depend on this parameter. For a possible explanation, I think that the conditions of fluid motion are different at the beginning 
of the experiment as in the rest of the reaction. The larger the area where the flow spreads at a given flow rate, the slower the flow of the high density liquid (this is also shown by the square root dependence in Figures and 6.4). Because small crystals form at the beginning of the experiment, intensive flow can carry and disperse them farther away. This is similar to that process how the river takes its sediment with itself. When the front propagates further, the intensity of the flow reduces while larger particles form. There is the boundary, where fluid flow is no longer able to carry these large precipitate particles with itself. The position of this boundary, that is the inner circle, depends on the given system (and particle size). Thus, we obtain different values for the inner circle using different chemicals. Applying the same volume flow rate, the inner circle of calcium oxalate is larger because calcium oxalate particles are smaller than calcium carbonate crystals. The inner circle of calcium carbonate owns larger crystals thus becomes smaller in size.

The carbonate ion and oxalate ion-containing calculations demonstrated that precipitates appear exactly the same $\mathrm{pH}$ values in the complex patterns, than the pure calcium oxalate and calcium carbonate. The precipitate pattern containing excess calcium carbonate has the smallest radius. The pattern that contained the most filaments was the sodium oxalate:sodium carbonate $=2: 1$, because the density difference was high enough, and less solids settled down than in the case of only the calcium oxalate precipitate - shown in Figure 7.1. This factor, as well as the low powder density of the excess calcium oxalate, favors filament formation.

Table 10.1: Parameters of calcium oxalate, calcium carbonate, and calcium oxalatecarbonate precipitate pattern.

\begin{tabular}{lccccc}
\hline \hline & calcium oxalate & calcium carbonate & \multicolumn{3}{c}{ complex pattern } \\
& pattern & pattern & $\mathbf{1 : 2}$ & $\mathbf{1 : 1}$ & $\mathbf{2 : 1}$ \\
\hline$c\left(\mathrm{Na}_{2} \mathrm{C}_{2} \mathrm{O}_{4}\right)$ & 0,010 & - & 0,0083 & 0,0125 & 0,0167 \\
$\left(\mathrm{~mol} \cdot \mathrm{dm}^{-3}\right)$ & & & & & \\
$c\left(\mathrm{Na}_{2} \mathrm{CO}_{3}\right)$ & - & 0,025 & 0,0167 & 0,0125 & 0,0083 \\
$\left(\mathrm{~mol} \cdot \mathrm{dm}^{-3}\right)$ & & & & & \\
$c\left(\mathrm{CaCl}_{2}\right)$ & 4,00 & 4,00 & 4,00 & 4,00 & 4,00 \\
$\left(\mathrm{~mol}^{-3} \mathrm{dm}^{-3}\right)$ & & & & & \\
$q \mathrm{~V}\left(\mathrm{~cm}^{3} \cdot \mathrm{h}^{-1}\right)$ & 20 & 20 & 20 & 20 & 20 \\
$\mathrm{pH}$ & 9,0 & 10,0 & 10,0 & 10,0 & 10,0 \\
$\Delta \rho\left(\mathrm{g} \cdot \mathrm{cm}^{-3}\right)$ & 0,3311 & 0,3312 & 0,3311 & 0,3311 & 0,3310 \\
$r_{\mathrm{O}}(\mathrm{mm})$ & 77 & 75 & 50 & 71 & 79 \\
$r_{\mathrm{i}}(\mathrm{mm})$ & 32 & 20 & - & 31 & 34 \\
\hline \hline
\end{tabular}


Calcium oxalate precipitate pattern contains more filaments than the calcium carbonate one. Since the powder density of calcium carbonate is greater than calcium oxalate, it can sediment faster. Resultantly, the precipitate is more evenly distributed and the filaments are less visible. Most preferably, the kinetics of precipitation is slow, therefore the precipitate is enriched only along the filaments (smilarly to the way how copper oxalate and cobalt oxalate precipitates). Based on these experimental results, the criteria for the formation of filament-containing precipitate patterns are the following:

(1) considerable density difference between the reactant solutions (which is also the condition of creating gravity flow)

(2) slow precipitation reaction

(3) sufficiently low powder density (that is slow sedimentation), and

(4) the precipitate that forms in a sufficiently small quantity

I have also shown that thermodynamically unstable calcium oxalate dihydrate crystals can be selectively produced under flow-driven conditions using high excess calcium ions and high flow rates. At the same time, only calcium oxalate monohydrate crystals could be detected in the well-stirred system. In the case of the calcium carbonate precipitate pattern, I also demonstrated that the morphology and size distribution of the crystals can be controlled with the volume flow rate. When I pumped calcium chloride solution at $20 \mathrm{~cm}^{3} \cdot \mathrm{h}^{-1}$ or smaller volume flow rate, calcite and vaterite crystals formed. Additionally, continuously larger vaterite and calcite crystals evolved in increasing distance from the calcium chloride inlet. If the volume flow rate was $20 \mathrm{~cm}^{3} \cdot \mathrm{h}^{-1}$ or higher, only calcite crystals precipitated. The properties of the precipitates formed in the flow-driven and in the well-stirred system are compared in Table 10.2. In the complex pattern, particles co-crystallized, and several interesting $\mathrm{x}$-shaped particles formed, which contained calcium oxalate monohydrate and calcite.

In the urea-urease reaction, urease enzyme catalyzes the enzymatic decomposition of urea, resulting in the formation of carbon dioxide and ammonia. It has been reported in the literature that calcium carbonate precipitate can be obtained via the carbon dioxidehydrogen carbonate ion-carbonate ion equilibrium, because calcium ions remove the carbonate ion content from the solution. The urea-urease reaction is autocatalytic to hydroxide ions, therefore, it can show a clock reaction in a well-stirred system. By adding calcium ions, the induction period increases and the final $\mathrm{pH}$ decreases. This observation is caused by the precipitation reaction between the urease enzyme and calcium ions, thus the effect of less active enzyme can be seen in the diagrams. Using more concentrated solutions of the reactants, the enzyme reaction can display transient $\mathrm{pH}$ oscillations and stepwise calcite formation. In these experiments, the final $\mathrm{pH}$ decreased, since calcium ion removes the carbon dioxide produced by the hydrogen carbonate ion-carbonate ion equilibrium while hydrogen ions are released. The modeling study of the oscillation is currently in progress; for the 
Table 10.2: Features of calcium oxalate and calcium carbonate precipitates formed in a wellstirred and in a flow-driven system.

\begin{tabular}{lcccc}
\hline \hline & calcium oxalate precipitate & \multicolumn{1}{c}{ calcium carbonate precipitate } \\
\hline similarities: & & $\begin{array}{l}\text { calcite and vaterite forms if } \\
\text { (1) solution is well-stirred } \\
\text { (2) } q_{\mathrm{V}} \geq 20 \mathrm{~cm}^{3} \cdot \mathrm{h}^{-1}\end{array}$ \\
& & & same morphology & \\
differences: & well-stirred & flow-driven & well-stirred & flow-driven \\
compound & $\mathrm{COM}$ & $\mathrm{COM}, \mathrm{COD}$ & calcite, vaterite & only calcite \\
size & below $\mu \mathrm{m}$ & $1-13 \mu \mathrm{m}$ & $4-5 \mu \mathrm{m}$ & $1-24 \mu \mathrm{m}$ \\
shape & rounded & octahedron, flower & sphere, rhombohedron & rhombohedron \\
structure & simple & complex & simple & simple \\
\hline \hline
\end{tabular}

preliminary results, see Figure IV.1 in Chapter IV („Függelék”). Comparing the model with the experimental results, it is seen that the period and the amplitude agrees well. We know that the formation of calcium carbonate precipitate decreases the $\mathrm{pH}$ and most of the enzyme becomes inactive because of its precipitate formed with calcium ion, resulting in a very slow carbonate ion production. I confirmed the presence of this precipitate by scanning electron microscopic images (Figure 8.9 A). We have to include additional parameters into the model, such as a certain supersaturation limit, and also the dynamic equilibrium of the dissolution and crystallization of smaller crystals. When the enzyme starts decomposing urea carbonate is produced, which will precipitate immediately as the solution becomes oversaturated. In this way, protons remain in the solution, therefore the $\mathrm{pH}$ rapidly decreases. Then, the small amount of enzyme will continue producing carbonate ions slowly, but it will precipitate with calcium ions again after a certain supersaturation limit. Probably, this process is repeated during the periods. I have constructed a review table (Table 10.3) to display the polymorphs and their size. 
Table 10.3: Calcium oxalate and calcium carbonate particles formed during the flow-driven and the urea-urease experiments.

\begin{tabular}{|c|c|c|c|c|c|}
\hline & \multicolumn{4}{|c|}{ flow-driven precipitate patterns } & \multirow{3}{*}{$\begin{array}{l}\text { enzyme reaction } \\
\text { calcium carbonate }\end{array}$} \\
\hline & \multicolumn{4}{|c|}{$\begin{array}{l}\text { calcium oxalate } \\
\text { volume }\end{array}$} & \\
\hline & 20 & 100 & $<20$ & $\geq 20$ & \\
\hline polymorph & $\begin{array}{c}\text { mainly } \\
\text { COM }\end{array}$ & $\begin{array}{l}\text { mainly } \\
\text { COD }\end{array}$ & $\begin{array}{c}\text { calcite and } \\
\text { vaterite }\end{array}$ & calcite & calcite \\
\hline morphology & $\begin{array}{l}\text { COM: } \\
\text { flower }\end{array}$ & $\begin{array}{c}\text { COD: } \\
\text { octahedron }\end{array}$ & $\begin{array}{l}\text { sphere and } \\
\text { rhombohedron }\end{array}$ & rhombohedron & rhombohedron \\
\hline size & inhor & $\begin{array}{l}\text { ogeneous } \\
13 \mu \mathrm{m}\end{array}$ & $\begin{array}{r}\text { inhomogeneous } \\
1-2\end{array}$ & $\begin{array}{l}\text { inhomogeneous } \\
\mu \mathrm{m}\end{array}$ & $\begin{array}{c}\text { inhomogeneous } \\
0,5-15 \mu \mathrm{m}\end{array}$ \\
\hline $\begin{array}{l}\text { spatial } \\
\text { distribution }\end{array}$ & & $\begin{array}{l}\text { larger par } \\
\text { intense } \\
\text { leation } \\
\text { torts it }\end{array}$ & $\begin{array}{l}\text { les further from th } \\
\text { well-defined } \\
\text { distribution } \\
\text { at } 1,3 \text {, and } 7 \mathrm{~cm}\end{array}$ & $\begin{array}{l}\text { inlet } \\
\text { but intense } \\
\text { nucleation } \\
\text { distorts it }\end{array}$ & irrelevant \\
\hline
\end{tabular}

Flow has an effect both on calcium oxalate and calcium carbonate, and can dictate which polymorph(s) is(are) evolving, and this way volume flow rate provided me a parameter, which operated as a "switch". On switching the flow rate I could control the forming structures of calcium oxalate and carbonate. In addition, calcite form of calcium carbonate can be produced by two methods: within the enzyme reaction and via intensive flow. 


\section{Irodalomjegyzék}

[1] N. H. Fletcher, The Nonlinear Acoustics of Musical Instruments, Jr. Acoust. Soc. of India, 17, 78-93 (1989).

[2] Z. Néda, E. Ravasz, Y. Brechet, T. Vicsek, A. L. Barabási, The Sound of Many Hands Clapping, Nature, 403, 849-850 (2000).

[3] http://www.feilding.net/sfuad/musi3012-01/html/lectures/009_hearing_IV.htm

[4] A. K. Dickerson, Z. G. Mills, D. L. Hu, Wet Mammals Shake at Tuned Frequencies to Dry, J. R. Soc. Interface, doi:10.1098/rsif.2012.0429 (2012).

[5] T. C. Devezas (Edited), Kondratieff Waves, Warfare and World Security, IOS Press, (2006) J. Dator, Alternative Futures for K-Waves p.311-317

[6] M.D. Graham, I.G. Ioannis, G. Kevrekidis, K. Asakura, J. Lauterbach, K. Krischer, H-H. Rotermund, G. Ertl, Effects of Boundaries on Pattern Formation: Catalytic Oxidation of CO on Platinum, Science 264, 80-82 (2004).

[7] K. Okamoto, A. Kijima, Y. Umeno, H. Shima, Synchronization in Flickering of Three-Coupled Candle Flames, Scientific Reports, 636145 (2016).

[8] D. M. Forrester, Arrays of Coupled Chemical Oscillators, Scientific Reports, 516994 (2015).

[9] A. M. Zhabotinsky, A History of Chemical Oscillations and Waves, Chaos, 1379-386 (1991).

[10] C. W. Bray, A Periodic Reaction in Homogeneous Solution and Its Relation to Catalysis, J. Am. Chem. Soc., 43, 1262-1267 (1921).

[11] C. W. Bray, H. A. Liebhafsky, Reactions Involving Hydrogen Peroxide, Iodine and Iodate Ion. I. Introduction, J. Am. Chem. Soc., 53, 38-44 (1931).

[12] A. T. Winfree, The Prehistory of the Belouszov-Zhabotinsky Oscillator, J. Chem. Educ., 61, 661-663, (1984).

[13] T. Tél, M. Gruiz, Kaotikus dinamika Nemzeti Tankönyvkiadó, Budapest, 2002.

\footnotetext{
*Valamennyi internetes forráshely 2017. 02. 20-án még elérhető volt.
} 
[14] Pap János, Akusztikai dzsessz, Nemlineáris jelenségek és káosz a zenei akusztikában, Természet Világa 136, (2005).

[15] V. Petrov, V. Gáspár, J. Masere, K. Showalter, Controlling Chaos in the Belousov-Zhabotinsky Reaction, Nature, 361, 240-243 (1993).

[16] V. Gáspár, A megszelídített káosz, A káoszszabályozás Természet Világa, 136, (2005).

[17] S. Kondo, R. Asai, A Reaction-Diffusion Wave on the Skin of the Marine Angelfish Pomacanthus, Nature, 376, 765-768 (1995).

[18] P.W. Atkins, Fizikai Kémia III. Változás, Nemzeti Tankönyvkiadó, 2002.

[19] T. Nakagaki, H. Yamada, Á. Tóth, Intelligence: Maze-Solving by an Amoeboid Organism, Nature 407, 470 (2000).

[20] M. J. Fuerstman, P. Deschatelets, R. Kane, A. Schwartz, P. J. A. Kenis, J. M. Deutch, G. M. Whitesides, Solving Mazes Using Microfluidic Networks, Langmuir 19, 4714-4722 (2003).

[21] D. R. Reyes, M. M. Ghanem, G. M. Whitesidec, A. Manz, Glow Discharge in Microfluidic Chips for Visible Analog Computing, Lab Chip, 2, 113-116 (2002).

[22] Cs. Vincze, I. Lagzi and R Mészáros, Húsz éve történt a csernobili katasztrófa: baleseti kibocsátás modellezése, Légkör, 51, 11-14 (2006).

[23] A. Gelencsér et al., The Red Mud Accident in Ajka (Hungary): Characterization and Potential Health Effects of Fugitive Dust, Environ. Sci. Technol. 45, 1608-1615, (2011).

[24] R.J. Field, M. Burger, Oscillations and Traveling Waves in Chemical Systems John Wiley \& Sons, 1985.

[25] Bazsa Gy., Nemlineáris dinamika és egzotikus kinetikai jelenségek kémiai rendszerekben Debrecen-Budapest-Gödöllő, 1992.

[26] I. Lagzi, B. Kowalczyk, D. Wang, B. A. Grzybowski, Nanoparticle Oscillations and Fronts, Angew. Chem. Int. Ed., 49, 8616-8619 (2010).

[27] I. Molnár, K. Kurin-Csörgei, M. Orbán, I. Szalai, Generation of Spatiotemporal Calcium Patterns Through Coupling a pH Oscillator to a Complexation Equilibrium, Chem. Commun., 50, 4158-4160 (2014).

[28] http://www2.sci.u-szeged.hu/physchem/nld/ejegyzet/nld.html*

[29] T. Bánsági, A. F. Taylor, Role of Differential Transport in an Oscillatory Enzyme Reaction, J. Phys. Chem. B, 118, 6092-6097 (2014).

[30] G. Hu, J. A. Pojman, S. K. Scott, M. M. Wrobel, A. F. Taylor, Base-Catalyzed Feedback in the Urea-Urease Reaction, J. Phys. Chem. B, 114, 14059-14063 (2010). 
[31] M. Novák, Cs. Visy, Some Observations on Oscllatory Phenomena in Anodic Oxidation, Acta Chimica Academiae Scientiarium Hungaricae, 105, 47-56 (1980).

[32] I. Nagypál, I.R. Epstein, Fluctuations and Stirring Rate Effects in the Chlorite-Thiosulfate Reaction, J. Phys. Chem. 90, 6285-6292 (1986).

[33] R. C. Desai, R. Kapral, Dynamics of Self-Organized and Self-Assembled Structures, Cambridge University Press, 2009.

[34] R. Arnold, K. Showalter, J.J. Tyson, Propagation of Chemical Reactions in Space, J. Chem. Educ. 64, 740-742 (1987).

[35] I. Nagypál, Gy. Bazsa, I.R. Epstein, Gravity-Induced Anisotropies in Chemical Waves, J. Am. Chem. Soc. 108, 3635-3640 (1986).

[36] L. Szirovicza, I. Nagypál, E. Boga, An Algorithm for the Design of Propagating Acidity Fronts, J. Am. Chem. Soc. 111, 2842-2845 (1989).

[37] M. M. Wrobel, T. Bánsági, S. K. Scott, A. F. Taylor, C. O. Bounds, A. Carranza, J. A. Pojman, pH Wave-Front Propagation in the Urea-Urease Reaction, Biophysical Journal, 103, 610-615 (2012).

[38] E. Jee, T. Bánsági, A. F. Taylor, J. A. Pojman, Temporal Control of Gelation and Polymerization Fronts Driven by an Autocatalytic Enzyme Reaction, Angew. Chem. Int. Ed., 55, 2127-2131 (2016).

[39] E. Tóth-Szeles, Á. Tóth, D. Horváth, Diffusive Fingering in a Precipitation Reaction Driven by Autocatalysis, Chem. Commun., 42 5580-5582 (2014).

[40] B. Bohner, G. Schuszter, H. Nakanishi, D. Zámbó, A. Deák, D. Horváth, Á. Tóth, I. Lagzi, Self-Assembly of Charged Nanoparticles by an Autocatalytic Reaction Front, Langmuir, 31, 12019-12024 (2015).

[41] A. N. Zaikin, A. M. Zhabotinsky, Concentration Wave Propagation in Two-Dimensional Liquid Phase Self-oscillating System, Nature, 225, 535-537 (1970).

[42] V. Castets, E. Dulos, J. Boissonade, P. De Kepper, Experimental Evidence of a Sustained Standing Turing-Type Nonequilibrium Chemical Pattern, Phys. Rev. Lett. 64, 2953-2956 (1990).

[43] M. Orbán, Molekulák önszervezódése idóben és térben: periodikus kémiai rendszerek, Magyar Tudomány, 7, 815-820 (2009).

[44] J. Horváth, I. Szalai, P. De Kepper, An Experimental Design Method Leading to Chemical Turing Patterns, Science 324, 772-775 (2009).

[45] T. Bánsági, V.K. Vanag, I.R. Epstein Tomography of Reaction-Diffusion Microemulsions Reveals Three-Dimensional Turing Patterns, Science 331, 1309-1312 (2011). 
[46] Q. Ouyang, H.L. Swinney Transition From a Uniform State to Hexagonal and Stripped Turing Patterns, Nature 352, 610-612 (1991).

[47] I. Molnár, I. Szalai, Pattern Formation in the Bromate-Sulfite-Ferrocyanide Reaction, J. Phys. Chem. A, 119, 9954-9961 (2015).

[48] B. A. Grzybowski, K. J. M. Bishop, C. J. Campbell, M. Filakowski, S. K. Smoukov, Micro- and Nanotechnology Via Reaction-Diffusion, Soft Matter, 1, 114-128 (2005).

[49] J.M. Gracía-Ruiz, E. Melero-Gracía, S.T. Hyde, Morphogenesis of Self-Assembled Nanocrystalline Materials of Barium Carbonate and Silica, Science 323, 362-365 (2009).

[50] E. Nakouzi, P. Knoll, K. B. Hendrix, O. Steinbock, Systematic Characterization of Polycrystalline Silica-Carbonate Helices Phys. Chem. Chem. Phys. 18, 23044-23052 (2016).

[51] M. Montalti, G. Zhang, D. Genovese, J. Morales, M. Kellermeier, J. M. Gracia-Ruiz, Local pH Oscillations Witness Autocatalytic Self-Organization of Biomorphic Nanostructures, Nature Comm. 8, 14427 (2017).

[52] C. N. Kaplan, W. L. Noorduin, L. Li, R. Sadza, L. Folkertsma, J. Aizenberg, L. Mahadevan, Controlled Growth and Form of Precipitating Microsculptures, Science, 355, 1395-1399 (2017).

[53] R.E. Liesegang, Ueber einige Eigenschaften von Gallerten, Naturwissenschaftliche Wochenschrift 30, 353-363 (1896).

[54] F. Izsák, I. Lagzi, A New Universal Law for the Liesegang Pattern Formation, J. Chem. Phys. 122, 184707 (2005).

[55] I. Lagzi, Precipitation Patterns in Reaction-Diffusion Systems, Research Signpost, 2010.

[56] R. Tóth, R. M. Walliser, I. Lagzi, F. Boudoire, M. Düggelin, A. Braun, C. E. Housecroft, E. Constable, Probing the Mystery of Liesegang Band Formation: Revealing the Origin of Self-Organized Dual-Frequency Micro and Nanoparticle Arrays, Soft Matter, 12, 8367-8374 (2016).

[57] M. Ripszám, Á. Nagy, A. Volford, F. Izsák, I. Lagzi, The Liesegang Eyes Phenomenon, Chem. Phys. Lett. 414, 384-388 (2005).

[58] M. Dayeh, M. Ammar, M. Al-Ghoul, Transition From Rings To Spots in a Precipitation Reaction-Diffusion System, RSC Adv. 4, 60034 (2014).

[59] M. Fiałkowski, A. Bitner, B. Grzybowski, Wave Optics of Liesegang Rings, Phys. Rev. Lett., 94, 018303 (2005).

[60] I. Lagzi, Formation of Liesegang Patterns in an Electric Field, Phys. Chem. Chem. Phys. 4, 1268-1270 (2002). 
[61] I. Bena, M. Droz, I. Lagzi, K. Martens, Z. Rácz, A. Volford, Designed Patterns: Flexible Control of Precipitation Through Electric Currents, Phys. Rev. Lett. 101, 075701 (2008).

[62] J. George, G. Varghese, Migrating Triplet Precipitation Bands of Calcium Phosphates in Gelatinous Matrix, J. of Mat. Sci., 40, 5557-5559 (2005).

[63] M. Zrínyi, L. Gálfi, é. Smidróczki, Z. Rácz, F. Horkay, Direct Observation from Heterogeneous Travelling Wave to Liesegang Pattern Formation, J. Phys. Chem., 95, 1618-1620 (1991).

[64] A. Adamatzky, B. de L. Costello, Reaction-Diffusion Path Planning in a Hybrid Chemical and Cellular-Automaton Processor, Chaos Solit. Fract. 16, 727-736 (2003).

[65] D. Zámbó, K. Suzuno, Sz. Pothorszky, D. Bárdfalvy, G. Holló, H. Nakanishi, D. Wang, D. Ueyama, A. Deák, I. Lagzi, Self-Assembly of Like-Charged Nanoparticles Into Voronoi Diagrams, Phys. Chem. Chem. Phys., 18, 25735-25740 (2016).

[66] P. Hantz, Pattern Formation in the $\mathrm{NaOH}+\mathrm{CuCl}_{2}$ Reaction, J. Phys. Chem. B, 104, 4266-4272 (2000).

[67] D. Bárdfalvy, I. Lagzi, Mintaképzódés nanorészecskék és szervetlen sók kölcsönhatásából, XXXVI. Kémiai Előadói Napok, 2013. október 28-30.

[68] A. Volford, I. Ferenc, M. Ripszám, I. Lagzi, Pattern Formation and Self-Organization in a Simple Precipitation System, Langmuir 23, 961-964 (2007).

[69] M. R. Tinsley, D. Collison, K. Showalter, Propagating Precipitation Waves: Experiments and Modeling, J. Phys. Chem. A, 117, 12719-12725 (2013).

[70] M. M. Ayass, I. Lagzi, M. Alg-Ghoul, Targets, Ripples, and Spirals in a Precipitation System with Anomalous Dispersion, Phys. Chem. Chem. Phys., 17, 19806-19814 (2015).

[71] S. Hill, Channelling in Packed Columns, Chem. Eng. Sci. 1, 247-253 (1952).

[72] Y. Nagatsu, S. Bae, Y. Kato, Y. Tada, Miscible Viscous Fingering with a Chemical Reaction Involving Precipitation, Phys. Rev. E, 77, 067302 (2008).

[73] J. R. Glauber, LXXXV. Wie man in diesem Liquore von allen Metallen in wenig Stunden Bäume mit Farben soll wachsen machen / How one shall make grow - in this solution, from all metals, in a few hours - trees with color, Philosophischer Oefen, 186-189 (1661).

[74] V. Kaminker, J. Maselko, J. Pantaleone, The Dynamics of Open Precipitation Tubes J. Chem. Phys. 140, 244901 1-7 (2014).

[75] D.E.H. Jones, U. Walter, The Silicate Garden Reaction in Microgravity: A Fluid Interfacial Instability, J Colloid. Interf. Sci. 203, 286-293 (1998).

[76] S. Thouvenel-Romans, J.J. Pagano, O. Steinbock, Bubble Guidance of Tubular Growth in Reaction-Precipitation systems, Phys. Chem. Chem. Phys. 7, 2610-2615 (2005). 
[77] J.J. Pagano, T. Bánsági, Jr., Oliver Steinbock, Bubble-Templated and Flow-Controlled Synthesis of Macroscopic Silica Tubes Supporting Zinc Oxide Nanostructures, Angew. Chem. Int. Ed. 47, 9900-9903 (2008).

[78] R. Makki, M. Al-Humiari, S. Dutta, Oliver Steinbock, Hollow Microtubes and Shells from Reactant-Loaded Polymer Beads, Angew. Chem. Int. Ed. 48, 8752-8756 (2009).

[79] J.J. Pagano, T. Bánsági, Jr., Oliver Steinbock, The Formation in Reverse Silica Gardens, J. Phys. Chem. C 111, 9324-9329 (2007).

[80] Rauscher Evelin, Áramlásvezérelt csapadékképzôdés a réz-foszfát és szilikát rendszerben, diplomamunka, SZTE, 2015.

[81] G. Schuszter, F. Brau, A. De Wit, Flow-Driven Control of Calcium Carbonate Precipitation in a Confined Geometry, Phys. Chem. Chem. Phys. 18, 25592-25600 (2016).

[82] G. Schuszter, F. Brau, A. De Wit, Calcium Carbonate Mineralization in a Confined Geometry, Environ. Sci. Technol. Lett. 3, 156-159 (2016).

[83] G. Schuszter, A. De Wit, Comparison of Flow-Controlled Calcium and Barium Carbonate Precipitation Patterns, J. Chem. Phys. 145, 224201-1-6 (2016).

[84] Á. Tóth, D. Horváth, R. Smith, J.R. McMahan, J. Maselko, Phase Diagram of Precipitation Morphologies in the $\mathrm{Cu}^{2+}-\mathrm{PO}_{4}^{3-}$ System J. Phys. Chem. C 111, 14762-14767 (2007).

[85] A. Baker, Á. Tóth, D. Horváth, J. Walkush, A. S. Ali, W. Morgan, Á. Kukovecz, J. J. Pantaleone, J. Maselko, Precipitation Pattern Formation in the Copper(II) Oxalate with Gravity Flow and Axial Symmetry J. Phys. Chem. A 113, 8243-8248 (2009).

[86] E. Tóth-Szeles, G. Schuszter, Á. Tóth, Z Kónya, D. Horváth, Flow-Driven Morphology Control in the Cobalt-Oxalate System, CrystEngComm. 18, 2057-2064 (2016).

[87] E. Nakouzi, O. Steinbock, Self-Organization in Precipitation Reactions Far From the Equilibrium Sci. adv., 2, 1601144 (2016).

[88] http://www.nobelprize.org/nobel_prizes/chemistry/laureates/1977/*

[89] http://www.nobelprize.org/nobel_prizes/chemistry/laureates/2007/*

[90] http://www .mke.org.hu/az-egyesrainmenu-100/kittett-kkusok-mainmenu-171/ szenyi-ds-mainmenu-173.html*

[91] Sz. Sándor, Ásványrendszertan, Miskolci Egyetemi Kiadó, 2007.

[92] R.F. Martin, W.H. Blackburn, Encyclopedia of Mineral Names: First update The Can. Mineral. 37, 1045-1078 (1999). 
[93] H. Yu, R. Sheikholeslami, W. O. S. Doherty, The Effect of Silica and Sugar on the Crysallographic and Morphological Properties of Calcium Oxalate J. Cryst. Growth 265, 592-603 (2004).

[94] T. Jung, W-S. Kim, C. K. Choi Crystal Structure and Morphology Control of Calcium Oxalate Using Biopolymeric Additivites in Crystallization J. Cryst. Growth 279, 154-162 (2005).

[95] S. Sandersius, P. Rez, Morphology of Crystals in Calcium Oxalate Monohydrate Kidney Stones Urol. Res. 35, 287-293 (2007).

[96] A-J. Xie, L. Zhang, J. Zhu, Y-H. Shen, Z. Xu, J-M. Zhu, C-H. Li, L. Chen, L-B. Yang, Formation of calcium oxalate concentric precipitate rings in two-dimensional agar gel systems containing $\mathrm{Ca}^{2+}-\mathrm{RE}^{3+}(\mathrm{RE}=\mathrm{Er}, \mathrm{Gd}$, and $\mathrm{La})-\mathrm{C}_{2} \mathrm{O}_{4}^{2-}$ Colloids and Surfaces A: Physicochem. Eng. Aspects 332, 192-199 (2009).

[97] D. Jáuregui-Zuniga, M.A. Ferrer, A.A. Caldreon, R. Munoz, A. Moreno, Heavy Metal Stress Reduces the Deposition of Calcium Oxalate Crystals in Leaves of Phaseolus Vulgaris J. Plant Physiol. 162, 1183-1187 (2005).

[98] N.Q. Dao, M. Daudon, Infrared and Raman Spectra of Calculi, Elsevier, Paris, 1997.

[99] B. Kowalczyk, K. J. M. Bishop, I. Lagzi, D. Wang, Y. Wei, S. Han, B. A. Grzybowski, Charged Nanoparticles as Supramolecular Surfactants of Controlling the Growth and Stability of Microcrystals, Nature Mat., 11, 227-232 (2012).

[100] S. Huang, K. Naka, Y. Chujo, A Carbonate Controlled-Addition Method for Amorphous Calcium Carbonate Spheres Stabilized by Poly(acrylic acid)s, Langmuir, 23, 12086-12095 (2007).

[101] Z. Wu, J. H. Davidson, L. F. Francis, Effect of Water Chemistry on Calcium Carbonate Deposition on Metal and Polymer Surfaces, J. Colloid Interf. Sci., 343, 176-187, (2010).

[102] R. Beck, J-P. Andeassen, Spherulitic Growth of Calcium Carbonate, Crysal Growth \& Design, 10, 2934-2947 (2010).

[103] W. Jiang, M. S. Pacella, D. Athanasiadou, V. Nelea, H. Vali, R. M. Hazen, J. J. Gray, M. D. McKee, Chiral Acidic Amino Acids Induce Chiral Hierarchical Structure in Calcium Carbonate, Nature Comm., 815066 (2017).

[104] J. A. Juhsz-Bortuzzo, B. Myszka, R Silva, A. R. Boccaccini, Sonosynthesis of Vaterite-type Calcium Carbonate, Crysal Growth \& Design, 17, 2351-2356 (2017).

[105] J. B. Sumner, The Isolation and Crystallization of the Enzyme Urease, J. Biol. Chem., 69 435-441 (1926).

[106] L. Chen, Y. Shen, A. Xie, B. Huang, R. Jia, R. Guo, W. Tang, Bacteria-Mediated Synthesis of Metal Carbonante Minerals with Unusual Morphologies and Structures, Crysal Growth \& Design, 9, 743-754 (2009). 
[107] A. Yashina, F. Meldrum, A. deMello, Calcium Carbonate Polymorph Control Using DropletBased Microfluidics, Biomicrofluidics 6, 022001 (2012).

[108] N. Qiu, H. Yin, B. Ji, A. Klauke, Y. Glidle, Y. Zhang, H. Song, L. Cai, L. Ma, G. Wang, L. Chen, W. Wang, Calcium Carbonate Microspheres as Carriers for the Anticancer Drug Camptothecin, Mater. Sci. Eng. C 32, 2634 (2012).

[109] D. Preisig, D. Haid, F.J.O. Varum, R. Bravo, R. Alles, J. Huwyer, M. Puchkov, Drug Loading into Porous Calcium Carbonate Microparticles by Solvent Evaporation, Eur. J. Pharm. Biopharm. 87, 548 (2014).

[110] B.V. Parakhonskiy, A.M. Yaschenok, S. Donotan, D.V. Volodkin, F. Tessarolo, R. Antolini, Macromolecule Loading into Spherical, Elliptical, Star-Like and Cubic Calcium Carbonate Carrier, Chem. Phys. Chem. 15, 2817 (2014).

[111] Y.N. Lee, Calcite Production by Bacillus Amyloliquefaciens, J. Microbiol. 41, 345 (2003).

[112] F.W. Küster, A. Thiel, Rechentafeln für die Chemische Analytik, Walter de Gruyter, 1985.

[113] http://www.sigmaaldrich.com/technical-documents/protocols/ biology/enzymatic-assay-of-urease-from-jack-beans.html*

[114] B. Bohner, G. Schuszter, O. Berkesi, D. Horváth, Á. Tóth, Self-Organization of Calcium Oxalate by Flow-Driven Precipitation, Chem. Commun., 50, 4289-4291 (2014).

[115] B. Bohner, B. Endrődi, D. Horváth, Á. Tóth, Flow-Driven Pattern Formation in the Calcium Oxalate system, J. Chem. Phys., 144, 164504-1-8 (2016).

[116] B. Bohner, G. Schuszter, D. Horváth, Á. Tóth, Morphology Control by Flow-Driven SelfOrganizing Precipitation, Chem. Phys. Lett., 631-632, 114-117 (2015).

[117] http://fityk.nieto.pl/*

[118] http://karman3.elte.hu/doc/bev-kornyaram-Janosi-Tel.pdf*

[119] http://plasma-gate.weizmann.ac.il/Grace/*

[120] http://mcj.sourceforge.net/*

[121] http://www.wolfram.com/mathematica/*

[122] S. Kotrlỳ, L. Šůcha, Handbook of Chemical Equilibria in Analytical Chemistry, Ellis Horwood Limited, 1985.

[123] R.A. Nyquist, R. O. Kagel, Infrared Spectra of Inorganic Compounds, Academic Press, 1971.

[124] F. Grases, A. Millan, A. Conte, Production of Calcium Oxalate Monohydrate, Dihydrate, or Trihydrate Urol. Res. 18, 17-20 (1990). 
[125] M. Yuzawa, K. Tozuka, A. Tokue, Effect of Citrate and Pyrophosphate on the Stability of Calcium Oxalate Dihydrate Urol. Res. 26, 83-88 (1998).

[126] L. Lepage, R. Tawashi, Growth and Characterization of Calcium Oxalate Dihydrate Crystals (Weddellite) J. Pharm. Sci. 71, 1059-1062 (1982).

[127] P. Brown, D. Ackermann, B. Finlayson, Calcium Oxalate Dihydrate (Weddellite) Precipitation J. Cryst. Growth 98, 285-292 (1989).

[128] M. Kiricsi, O. Berkesi, Vesekövek osztályozása, A kémia tanítása, 3-8 (1997).

[129] S.B. Mukkamala, C.E. Anson, A.K. Powell, Modelling Calcium Carbonate Biomineralisation Processes J. Inorg. Biochem. 100, 1128-1138 (2006).

[130] http://rruff.info/*

[131] G. Behrens, L. T. Kuhn, R. Ubic, A. H. Heuer, Raman Spectra of Vateritic Calcium Carbonate Spectrosc. Lett., 28, 983-995 (1995). 


\section{Függelék}

\section{A mintázatképződés illusztrálására szolgáló kísérletek leírása}

\section{I.1. Spirálok képzódése a Belouszov-Zsabotyinszkij-reak- cióban}

Gerjeszthető rendszert állítottam elő a Belouszov-Zsabotyinszkij-reakcióban a következő recept felhasználásával: $3,8 \mathrm{ml} 1 \mathrm{~mol} \cdot \mathrm{dm}^{-3}$ kénsavat, $2,2 \mathrm{ml} 2 \mathrm{~mol} \cdot \mathrm{dm}^{-3}$ nátrium-bromátoldatot, valamint $1 \mathrm{ml} \quad 0,5 \mathrm{~mol} \cdot \mathrm{dm}^{-3}$ malonsav-oldatot elegyítettem $2 \mathrm{ml}$ $0,1 \mathrm{~mol} \cdot \mathrm{dm}^{-3}$ kálium-bromid-oldattal. Petri-csészébe öntöttem, majd a sárga szín eltú-

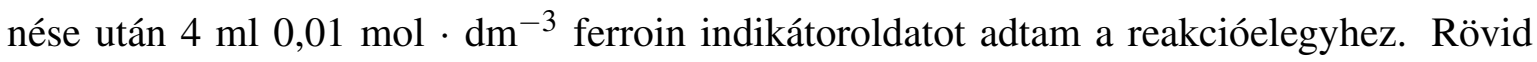
indukciós periódus után kék spirálokat figyeltem meg a piros színú folyadékban, melyrôl készült képfelvétel a 2.3. ábrán látható.

\section{I.2. Az alumínium-hidroxid mozgó csapadékmintázat}

A kísérletekhez $150 \mathrm{~cm}^{3} 1 \mathrm{~m} / \mathrm{m} \%$ agaróz gélt készítettem $0,29 \mathrm{~mol} \cdot \mathrm{dm}^{-3}$ alumínium-kloridtartalommal, melyet egy $17 \mathrm{~cm}$ átmérőjű Petri-csészébe öntöttem ki. A gél elkészítéséhez az agaróz port a megfelelô mennyiségú vízben duzzadni hagytam, majd enyhe kevertetés mellett melegíteni kezdtem. Amint a hőmérséklet elérte a $70{ }^{\circ} \mathrm{C}$-ot, kikapcsoltam a fútést, és kevertettem az oldatot addig, amíg a főzőpohár tartalma teljesen átlátszó lett. Eközben a hőmérséklet elérte 80-90 ${ }^{\circ} \mathrm{C}$-ot. Ezt követően hozzáadtam a szilárd alumínium-kloridot, és feloldottam. Állni hagytam az oldatot, hogy a kevertetés hatására képződött buborékok távozzanak még mielőtt a Petri-csészébe öntöm a gélt. Amint az agaróz gél megszilárdult, $75 \mathrm{~cm}^{3} 2,5 \mathrm{~mol} \cdot \mathrm{dm}^{-3}$ nátrium-hidroxid-oldatot öntöttem a felszínére. Perceken belül megjelentek a 2.7. B ábrán látható spirál és kettôsspirál alakzatok. A mintázat egy-két órán keresztül látható, majd telítődik és megáll. 


\section{I.3. Szilikátnövények}

A 2.9 szemléltetett szilikátnövények $200 \mathrm{~cm}^{3}$ térfogatú nátrium-szilikát vizes oldatába helyezett késhegynyi $\mathrm{MnSO}_{4^{-}}, \mathrm{NiCl}_{2^{-}}, \mathrm{NiSO}_{4^{-}}, \mathrm{CoCl}_{2^{-}}, \mathrm{Co}\left(\mathrm{NO}_{3}\right)_{2^{-}}, \mathrm{AlCl}_{3^{-}}, \mathrm{AgNO}_{3^{-}}, \mathrm{CuSO}_{4^{-}}$, $\mathrm{CuCl}_{2-}, \mathrm{FeSO}_{4-}, \mathrm{Fe}_{2}\left(\mathrm{SO}_{4}\right)_{3}$-sókból fejlôdtek ki. A sókból létrejött szilikátnövények összetételét könnyedén megállapíthatjuk az eredeti sókristály és a színük alapján, melyet az I.1. táblázatban összegeztem.

I.1. táblázat. A szilikátnövények színe.

\begin{tabular}{ll}
\hline \hline átmenetifémsó & csố színe \\
\hline $\mathrm{AlCl}_{3}$ & fehér \\
$\mathrm{AgNO}_{3}$ & sárga \\
$\mathrm{CoCl}_{2}$ & kék \\
$\mathrm{Co}\left(\mathrm{NO}_{3}\right)_{2}$ & kék \\
$\mathrm{CuSO}_{4}$ & kék \\
$\mathrm{CuCl}_{2}$ & sötétkék \\
$\mathrm{FeSO}_{4}$ & sötétszürke \\
$\mathrm{Fe}_{2}\left(\mathrm{SO}_{4}\right)_{3}$ & narancssárga \\
$\mathrm{MnSO}_{4}$ & fehér \\
$\mathrm{NiCl}_{2}$ & zöld \\
$\mathrm{NiSO}_{4}$ & zöld \\
\hline \hline
\end{tabular}

\section{I.4. Réz-oxalát szálas csapadékmintázat}

Perisztaltikus pumpa segítségével $0,8 \mathrm{~mol} \cdot \mathrm{dm}^{-3}$ koncentrációjú réz-szulfát-oldatot áramoltattam $6 \mathrm{~cm}^{3} \cdot \mathrm{h}^{-1}$ térfogat-áramlási sebességgel egy négyzet alapú üvegedénybe, amely $0,05 \mathrm{~mol} \cdot \mathrm{dm}^{-3}$ koncentrációjú nátrium-oxalát-oldatot tartalmazott. Az edény alján szálas szerkezettel rendelkező kékeszöld csapadék vált le, amelyről készült felvétel a 2.11. ábrán látható. 


\section{Függelék}

\section{Termogravimetriás számítások}

Példaszámolás az elméleti tömegveszteségek számításához:

A kalcium-oxalát-monohidrát $290{ }^{\circ} \mathrm{C}$-on történô vízvesztéséhez tartozó tömegveszteség $(a)$ számítása:

$$
a=\frac{M_{\mathrm{H}_{2} \mathrm{O}}}{M_{\mathrm{Ca}(\mathrm{COOH})_{2} \cdot 1 \mathrm{H}_{2} \mathrm{O}}}=\frac{18,02}{146,11}=0,123
$$

Az $550{ }^{\circ} \mathrm{C}$-on történő karbonátosodáshoz tartozó tömegveszteség (b) számítása:

$$
b=\frac{M_{\mathrm{CO}}}{M_{\mathrm{Ca}(\mathrm{COOH})_{2}}}=\frac{28,01}{128,10}=0,219
$$

A $900{ }^{\circ}$ C-on történő oxidképződéshez tartozó tömegveszteség $(c)$ számítása:

$$
c=\frac{M_{\mathrm{CO}_{2}}}{M_{\mathrm{CaCO}_{3}}}=\frac{44,01}{100,09}=0,440
$$

A többi számítást is ezen példa alapján végeztem el. 


\section{Függelék}

\section{Számítások a Wolfram Mathematica Programmal}

\section{III.1. Egyensúlyi számítások bemeneti adatai}

Protonálódási állandók, komplexek stabilitási állandói:

$\log \mathrm{K}=\{10.33-14,6.35-14,-1.46\}$

$\mathrm{b} 1=\left\{10^{\wedge} \log \mathrm{K}[[1]], 10^{\sim}(\log \mathrm{K}[[1]]+\log \mathrm{K}[[2]])\right\}$

$\log \mathrm{BCaCO} 3=3.15$

$\mathrm{b} 2 \mathrm{H}=10^{-}(1.00+\log \mathrm{K}[[1]])$

b3 $=10-1.15$

$\mathrm{HCO}=\mathrm{b} 1[[1]] \quad \mathrm{CO} 3 / \mathrm{OH}$

$\mathrm{H} 2 \mathrm{CO} 3=\mathrm{b} 1[[2]] \quad \mathrm{CO} 3 / \mathrm{OH}^{\wedge} 2$

$\mathrm{CaCO} 3=10^{\wedge} \operatorname{logBCaCO} 3 \mathrm{Ca} \mathrm{CO3}$

$\mathrm{CaHCO} 3=\mathrm{b} 2 \mathrm{H} \mathrm{Ca} \mathrm{CO} 3 / \mathrm{OH}$

$\mathrm{CaOH}=\mathrm{b} 3 \quad \mathrm{Ca} \mathrm{OH}$

Oldhatósági szorzatok, és a reaktánsok megadása:

$\mathrm{KspCaCO3}=10^{-}-8.35$

$\mathrm{KspCaOH} 2=10^{-}-5.19$

$\mathrm{Ca}=\mathrm{KspCaOH} 2 / \mathrm{OH}^{\sim} 2$

$\mathrm{CO} 3=\mathrm{KspCaCO} 3 / \mathrm{Ca}$

Mérlegegyenletek:

$\mathrm{cCO} 3=\mathrm{CO} 3+\mathrm{HCO} 3+\mathrm{H} 2 \mathrm{CO} 3+\mathrm{CaCO} 3+\mathrm{CaHCO} 3+\mathrm{CaCO} 3 \mathrm{~s}$

$\mathrm{cCa}=\mathrm{Ca}+\mathrm{CaOH}+\mathrm{CaCO} 3+\mathrm{CaHCO} 3+\mathrm{CaCO} 3 \mathrm{~s}+\mathrm{CaOH} 2 \mathrm{~s}$

Megoldás : 


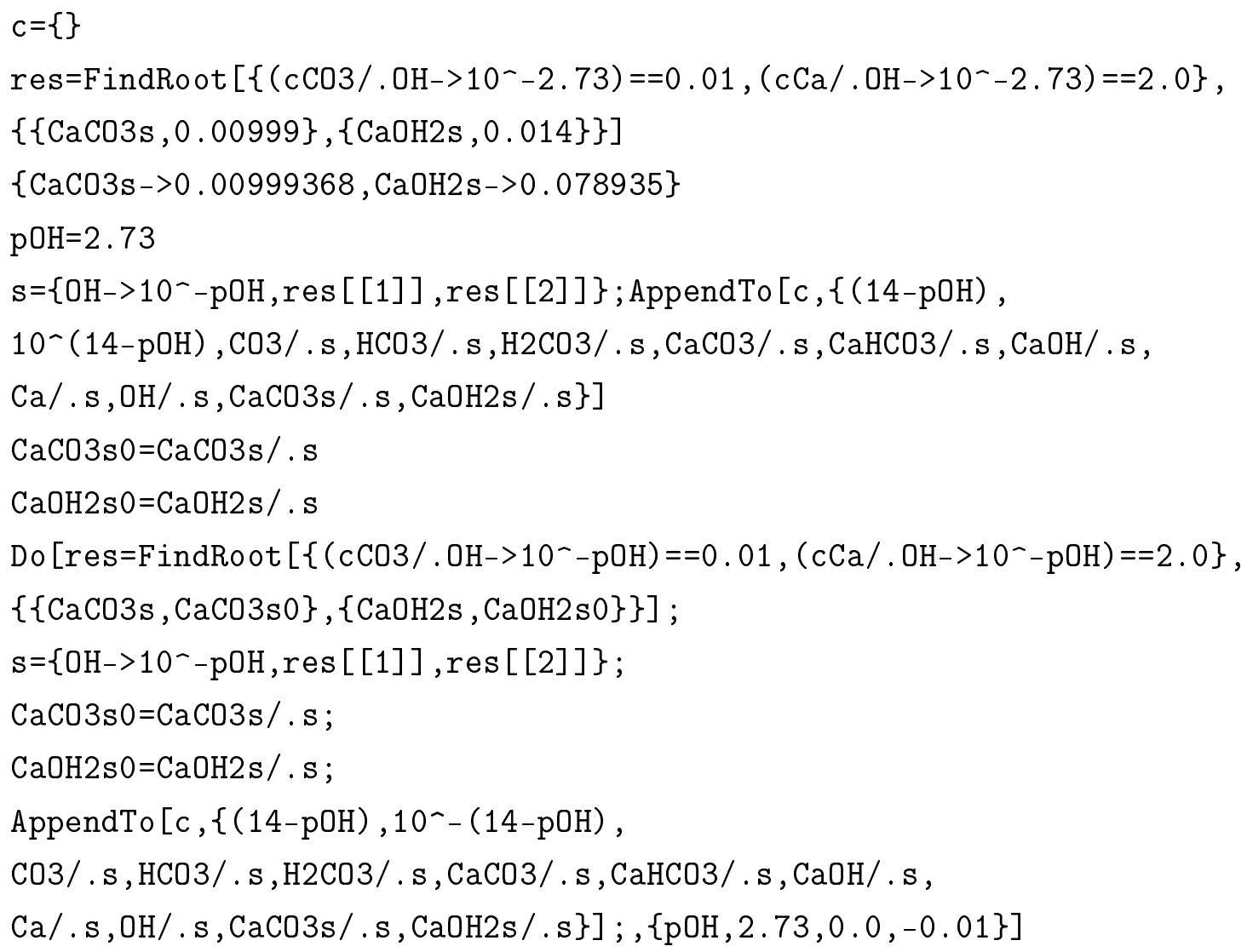

\section{III.2. Háromparaméteres egyenlet illesztése a csapadékkör külsố sugarának növekedésére}

Adatok:

$\operatorname{In}[1]:=\operatorname{data}=\{\{0 ., 2.432526\},\{0.66666667,20.062284\},\{1.3333333,29.916955\}$, $\{2 ., 38.550173\},\{2.6666667,47.231834\},\{3.3333333,54.591696\}$, $\{4 ., 61.480969\},\{4.6666667,67.910035\},\{5.3333333,74.138408\}$, $\{6 ., 80.204152\},\{6.6666667,86.117647\},\{7.3333333,91.678201\}$, $\{8 ., 96.930796\},\{8.6666667,101.9827\}\}$;

Illesztés:

$\operatorname{In}[2]:=$ nlm=NonlinearModelFit $[$ data, $a 0$ Sqrt $[x+a 1]+a 2,\{\{a 0,44$.$\} ,$ $\{\mathrm{a} 1,0.7\},\{\mathrm{a} 2,-33\}.\}, \mathrm{x}]$ Out $[2]=$ FittedModel $[-33.4935+44.0461 \operatorname{Sqrt}[0.703023+x]]$

Az illesztés paraméterei:

In [3] := nlm [' 'ParameterTable ' ']

Out [3]= Estimate Standard Error t-Statistic P-Value a0 $44.0461 \quad 0.91335648 .2245 \quad 3.73853 * 10^{-1}-14$ 
a1 $0.703023 \quad 0.117487 \quad 5.98386 \quad 0.0000913566$

a2 $-33.49353 .28953-10.1818 \quad 6.17294 * 10^{-}-7$

\section{III.3. A pH számítása kalciumionok és ammónium-karbonát mellett}

Protonálódási állandók, komplexek stabilitási állandói:

$\operatorname{In}[1]:=\operatorname{logKHCO} 3=\{10.33,6.35\}$

$\operatorname{In}[2]:=\mathrm{b} 1=10^{\wedge} \log \mathrm{KHCO} 3[[1]]$

$\operatorname{In}[3]:=\mathrm{b} 2=10^{-}(\operatorname{logKHCO} 3[[1]]+\operatorname{logKHCO} 3[[2]])$

$\operatorname{In}[4]:=\mathrm{HCO}=\mathrm{b} 1 \quad \mathrm{H} \quad \mathrm{CO} 3$

$\operatorname{In}[5]:=\mathrm{H} 2 \mathrm{CO} 3=\mathrm{b} 2 \quad \mathrm{H}^{\wedge} 2 \quad \mathrm{CO} 3$

$\operatorname{In}[6]:=\operatorname{logKNH3}=9.244$

$\operatorname{In}[7]:=\mathrm{b} 3=10^{\wedge} \log \mathrm{KNH} 3$

$\operatorname{In}[8]:=\mathrm{NH} 4=\mathrm{NH} 3 \mathrm{H}$ b3

$\operatorname{In}[9]:=\log \mathrm{Kv}=14$

$\operatorname{In}[10]:=\mathrm{Kv}=10^{-}-14$

$\operatorname{In}[11]:=\mathrm{OH}=\mathrm{Kv} / \mathrm{H}$

$\operatorname{In}[12]:=\mathrm{bCaCO} 3=10-3.15$

In $[13]:=\mathrm{CaCO} 3=\mathrm{bCaCO} 3 \mathrm{Ca} \mathrm{CO}$

$\operatorname{In}[14]:=\mathrm{bCaHCO}=10-(1.00+\log \mathrm{KHCO} 3[[1]])$

$\operatorname{In}[15]:=\mathrm{CaHCO} 3=\mathrm{bCaHCO} 3 \mathrm{Ca} \mathrm{H} \mathrm{CO} 3$

$\operatorname{In}[16]:=\mathrm{bCaOH}=10^{-}(1.15-\operatorname{logKv})$

$\operatorname{In}[17]:=\mathrm{CaOH}=\mathrm{bCaOH} \quad \mathrm{Ca} / \mathrm{H}$

Oldhatósági szorzatok:

$\operatorname{In}[18]:=\mathrm{KspCaCO3}=10^{-}-8.35$

$\operatorname{In}[19]:=\mathrm{KspCaOH} 2=10^{-}(-5 \cdot 19+214)$

Komponensmérleg-egyenletek:

In $[20]:=c \mathrm{CO} 3=\mathrm{CO} 3+\mathrm{HCO} 3+\mathrm{H} 2 \mathrm{CO} 3+\mathrm{CaCO} 3+\mathrm{CaHCO} 3+\mathrm{CaCO} 3 \mathrm{~s}$

In $[21]:=c \mathrm{Ca}=\mathrm{Ca}+\mathrm{CaOH}+\mathrm{CaCO} 3+\mathrm{CaHCO}+\mathrm{CaCO} s \mathrm{~s}$

$\operatorname{In}[22]:=\quad$ NH3 $=\mathrm{NH} 3+\mathrm{NH} 4$

Töltésmérleg-egyenlet:

$\operatorname{In}[23]:=\mathrm{Eqq}=\mathrm{NH} 4+\mathrm{H}+2 * \mathrm{Ca}+\mathrm{CaOH}==2 * \mathrm{CO} 3+\mathrm{HCO} 3+\mathrm{OH}+\mathrm{Cl}$

Megoldás : 


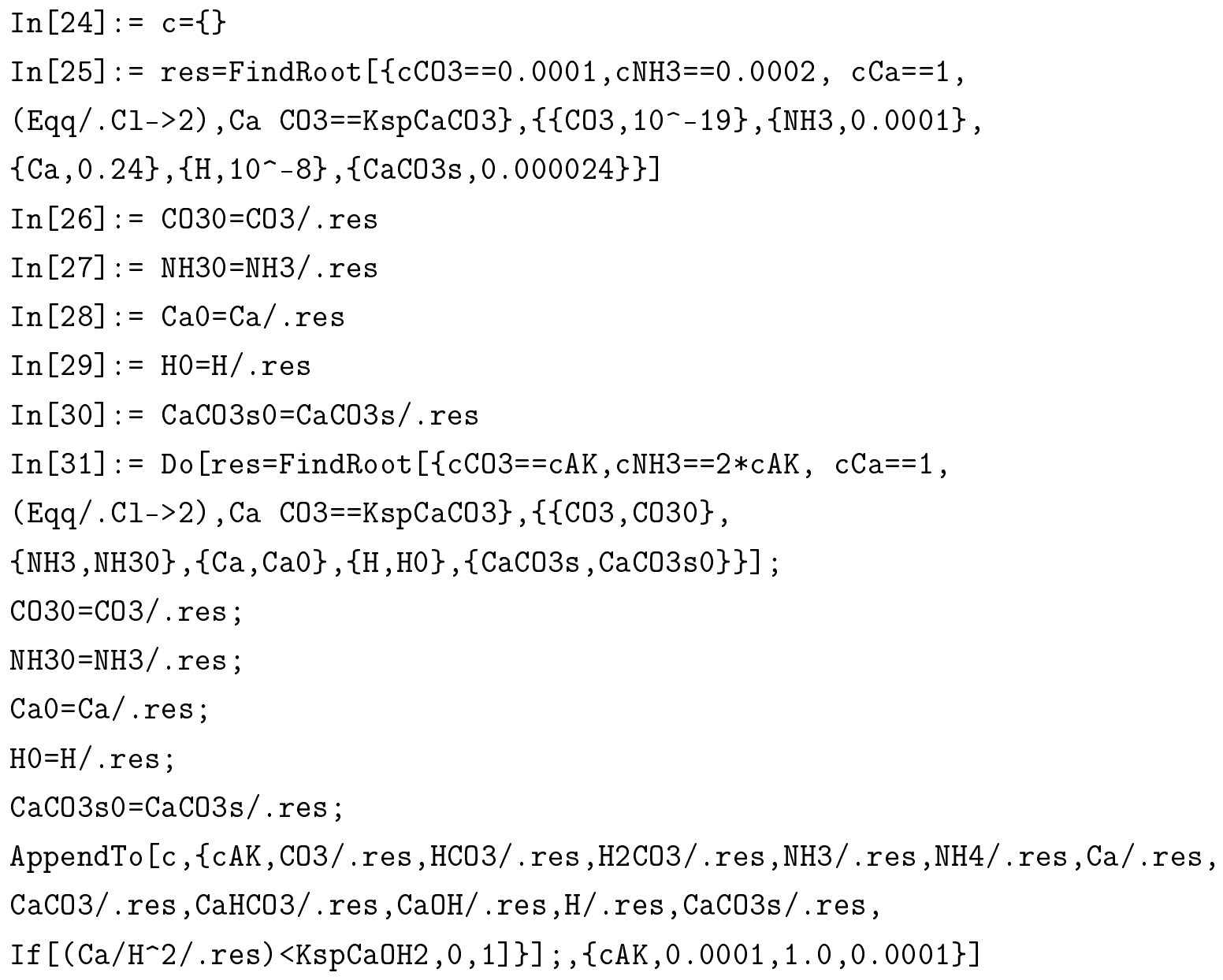




\section{Függelék}

\section{A karbamid-ureáz-kalciumion oszcilláló kémiai reakció modellezésének elôzetes eredménye}

A karbamid-ureáz-kalciumion kémiai reakcióban bekövetkezô oszcillálció modellezésével a kooperációban résztvevő partnerünk foglalkozik. Eredményeik közül a IV.1. ábrát szeretném bemutatni, melyen a periódusidő, és az amplitúdó is jó egyezést mutat a kísérleti tapasztalatokkal.

$\mathrm{PH}$ vs T

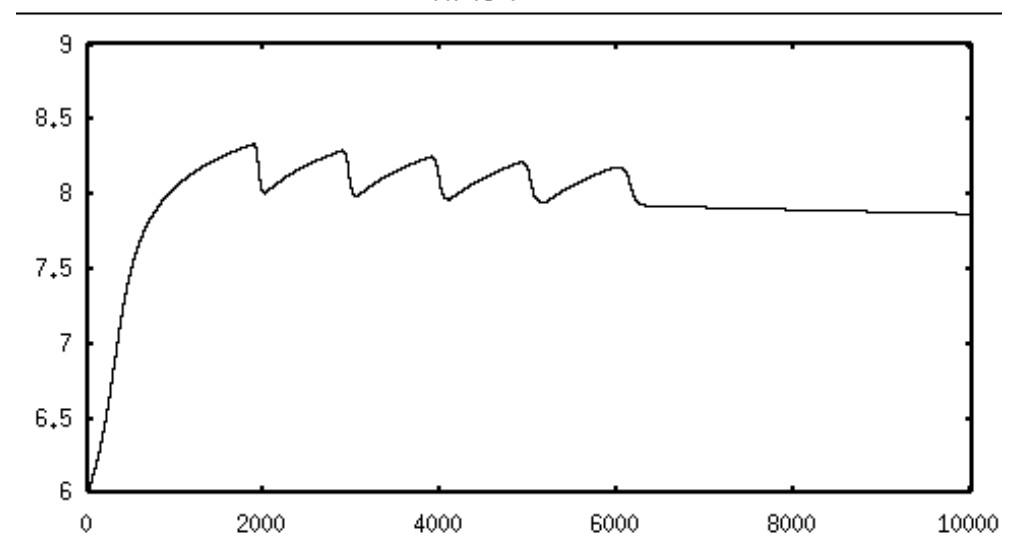

IV.1. ábra. A karbamid-ureáz-kalciumion kémiai reakcióban bekövetkezô oszcilláció modellezése. 


\section{Köszönetnyilvánítás}

Ezúton szeretnék köszönetet mondani témavezetôimnek Dr. Horváth Dezsốnek, valamint Dr. Tóth Ágotának szakmai tanácsaikért és segítségükért, valamint azért, hogy lehetővé tették számomra a négy féléves angol-magyar természettudományi szakfordító képzés elvégzését is, doktori tanulmányaimmal párhuzamosan. Köszönöm Dr. Annette Taylornak, és Dr. Bánsági Tamásnak, hogy felejthetetlenné tették a Sheffieldben, Angliában végzett kutatómunkámat. Szakmai vezetésük és segítségük, valamint jóindulatuk sokat jelentett nekem.

Nagyra becsülöm a különböző múszeres mérések során nyújtott segítségét Dr. Berkesi Ottónak, Bujdosó Tamásnak, Dr. Endrődi Balázsnak, Dr. Galbács Gábornak, Dr. Janovák Lászlónak, Dr. Szúcs Árpádnak, Dr. Schuszter Gábornak és Varga Andrásnak. Nagyon örülök, hogy a kutatócsoport volt és jelenlegi tagjai segítókészek és kiváló humorérzékkel rendelkeznek, így jó hangulatban végezhettem a munkámat. Köszönöm családomnak a támogatást, valamint középiskolai kémia tanárnőmnek Virág Tibornénak azt, hogy megismertette velem a kémia szépségeit. Pótolhatatlan úrt jelentett volna számomra, ha Csipak Brigittával az egyetemi beiratkozás napján nem kötök barátságot. Szinte hihetetlen, hogy bármiben, bármilyen körülmények között számíthattam rá.

Elsősorban azonban vőlegényemnek, Dr. Janáky Csabának tartozom hálával, hiszen lelki támaszt nyújtott, erôt adott, és gondolataiban is mindvégig elkísért. Köszönöm, hogy mellettem állt a legnehezebb pillanatokban és bátorításával hozzásegített céljaim eléréséhez. 